\author{
UNIVERSIDADE DE SÃO PAULO \\ FACULDADE DE ECONOMIA, ADMINISTRAÇÃO E CONTABILIDADE \\ DEPARTAMENTO DE ECONOMIA \\ PROGRAMA DE PÓS-GRADUAÇÃO EM ECONOMIA
}

\title{
Essays in weather impacts on economy
}

Ensaios sobre os impactos de variações climáticas na economia Bruno Toni Palialol Orientador: Profa. Paula Carvalho Pereda

São Paulo - Brasil

2020 

Prof. Dr. Vahan Agopyan

Reitor da Universidade de São Paulo

Prof. Dr. Fabio Frezatti

Diretor da Faculdade de Economia, Administração e Contabilidade

Prof. Dr. Jose Carlos de Souza Santos

Chefe do Departamento de Economia

Prof. Dr. Ariaster Baumgratz Chimeli

Coordenador do Programa de Pós-Graduação em Economia 



\section{BRUNO TONI PALIALOL}

Tese apresentada ao Departamento de Economia da Faculdade de Economia, Administração e Contabilidade da Universidade de São Paulo como requisito parcial para a obtenção do título de Doutor em Ciências.

Área de concentração: Teoria Econômica

Orientador: Prof ${ }^{\mathrm{a}}$. Paula Carvalho Pereda

Versão Corrigida

(versão original disponível na Biblioteca da Faculdade de Economia, Administração e Contabilidade)

São Paulo - Brasil

2020 
Palialol, Bruno Toni.

Essays in weather impacts on economy / Bruno Toni Palialol. - São Paulo, 2020. $166 \mathrm{p}$.

Tese (Doutorado) - Universidade de São Paulo, 2020. Orientador: Paula Carvalho Pereda.

1. Weather variations. 2. Panel data. 3. Impact evaluation. I. Universidade de São Paulo. Faculdade de Economia, Administração e Contabilidade. II. Título. 
Dedicado a todos que insistem em ir além. 



\section{AGRADECIMENTOS}

Começo esta seção agradecendo à Faculdade de Economia Administração e Contabilidade (FEA) e ao Departamento de Economia por propiciarem a existência de um ambiente inspirador e voltado ao desenvolvimento da ciência. A todos meus mestres que de alguma forma contribuiram para a conclusão dessa aventura, muito obrigado.

Um agradecimento especial ao Núcleo de Economia Regional e Urbana (NEREUS) pelo apoio ao longo curso e disponibilização do servidor, sem o qual este trabalho não teria sido possível. Aos alunos do NEREUS, grato pelas dicas, conversas e apoio mútuo.

Aos meus amigos de Mestrado e Doutorado, Alexander Chow, Bruno Cordeiro, Denise Li, Elias Cavalcante e Gabriel Lyrio pelo companheirismo nessa jornada. Aos já de longa data amigos Danilo Souza e Raí Chicoli pela amizade e apoio contínuos dos últimos 11 anos.

Aos meus pais, por me ensinarem os valores morais sem os quais não teria chegado até aqui. À minha namorada, Marjorie Iacoponi, pelas palavras de apoio e por sempre compreender o recorrente "não posso, tenho que fazer a Tese". Ao meu fiel escudeiro, Theodoro, pelo sempre inabalável companheirismo nas madrugadas adentro.

Por último, mas definitivamente não menos importante, agradeço à minha orientadora, professora Paula Pereda, pelos ensinamentos e incansável busca pela excelência. Ainda me surpreendo com os exemplos de bondade e extremo zelo para com o próximo. Não teria me tornado o profissional que sou sem seu apoio. Serei eternamente grato.

O presente trabalho foi realizado com apoio da Fundação Instituto de Pesquisas Econômicas (Fipe). 

"You must be shapeless, formless, like water. Become like water my friend." 



\section{RESUMO}

Esta tese examina três tópicos relacionando clima e seus efeitos econômicos. O primeiro capítulo, intitulado "Do temperature shocks affect non-agriculture wages in Brazil? Evidence from individual-level panel data" testa se a temperatura afeta a produtividade do trabalho nos mercados de trabalho formais no Brasil. São utilizados dados mensais de trabalhadores de janeiro de 2015 a dezembro de 2016. Os resultados mostram que um choque de $1^{\circ} \mathrm{C}$ aumenta os salários onde as temperaturas são mais frias, mas reduz os salários onde as temperaturas são mais altas. Os salários caem $0,42 \%$ em média, uma perda de renda equivalente a $0,06 \%$ do PIB anualmente. Supondo que as temperaturas futuras aumentem uniformemente em $2^{\circ} \mathrm{C}$, e que nenhuma adaptação ocorra, esperamos perdas anuais de renda cinco vezes maiores. Os efeitos heterogêneos que encontramos também sugerem que a vulnerabilidade climática pode aprofundar as desigualdades de renda existentes no país. O segundo capítulo, intitulado "Does weather influence COVID19 transmission?" usa um painel diário global de 416 regiões e 93 dias, juntamente com múltiplos efeitos fixos, para concluir que a temperatura reduz a transmissão do COVID-19 em 8,98\%. Esses efeitos são mais fortes em climas frios, áridos e secos, diminuindo a propagação em 12,86\%,12,08\% e 10,08\%, respectivamente. Ainda assim, não está claro se as condições climáticas podem parar ou retardar o surto, mas devem ser incluídas em modelos para prever casos futuros da doença. O terceiro capítulo, intitulado "Weather variations and impacts on mortality in Brazil", utiliza um painel anual de 2.198 municípios de 1980 a 2012 e interage choques climáticos com clima de longo prazo para estimar efeitos não lineares do clima na saúde. Constatamos que choques positivos de precipitação $(+1 \mathrm{~mm}) \mathrm{em}$ uma estação chuvosa aumentam em $0,02 \%$ as taxas de mortalidade de crianças entre 0 e 4 anos de idade. Os resultados sugerem que cidades com baixos níveis de educação e infraestrutura são mais afetadas pelas variações de temperatura e precipitação. Essas descobertas ajudarão a melhorar os modelos econômicos, esclarecendo os principais determinantes da relação clima-saúde.

Palavras-chaves: Variações climáticas, Dados em painel, Avaliação de impacto 



\section{ABSTRACT}

This thesis examines three topics relating weather and economic outcomes. The first chapter, entitled "Do temperature shocks affect non-agriculture wages in Brazil? Evidence from individual-level panel data" asks whether there is a causal link between temperature and labor productivity in Brazil's formal labor markets. To that end, we use monthly individual-level panel data spanning January 2015 to December 2016. Our results show that a $1^{\circ} \mathrm{C}$ shock increases wages where climate temperatures are colder, but reduces wages where climate temperatures are hotter. We calculate that wages fall $0.42 \%$ on average, an income loss equivalent to $0.06 \%$ of GDP annually. Assuming future temperatures rise uniformly by $2^{\circ} \mathrm{C}$, and that no adaptation occurs, we expect annual income losses five times larger. The heterogeneous effects we find also suggest that weather vulnerability may deepen existing income inequalities. The second chapter, entitled "Does weather influence COVID-19 transmission?" uses a global cross-region panel of daily data on 416 regions and 93 days, with multiple fixed effects, and explore the exogenous variations of weather variables to find that temperature reduces COVID-19 transmission up to $8.98 \%$. These effects are stronger in cold, arid and dry climates, diminishing propagation by $12.86 \%, 12.08 \%$ and $10.08 \%$, respectively. Still, it is not clear whether climatic conditions can alone stop or slow the outbreak, but they should be included in models to predict future cases of the disease. The third chapter, entitled "Weather variations and impacts on mortality in Brazil" uses an annual panel of 2,198 municipalities from 1980 to 2012 and interacts weather shocks with climate normals to estimate non-linear effects of climate on health. We find that

positive precipitation shocks $(+1 \mathrm{~mm})$ in a rainy season, increase mortality rates of children between 0 and 4 years old by $0.02 \%$. Results suggest cities with low levels of education and infrastructure are more affected by temperature and precipitation variations. Our findings will help improving economic models by shedding light on key determinants of the weather-health relation.

Key-words: Weather variations, Panel data, Impact evaluation 



\section{TABLE OF CONTENTS}

1 Do temperature shocks affect non-agriculture wages in Brazil? Evidence from individual-level panel data . . . . . . . . . . . . . . 17

1.1 Introduction . . . . . . . . . . . . . . . . . . . . . 17

1.2 Empirical approach . . . . . . . . . . . . . . . . . . . . . 22

1.3 Wage and weather data . . . . . . . . . . . . . . . 24

1.3.1 Employer-employee panel . . . . . . . . . . . . . . 24

1.3.2 Monthly weather data . . . . . . . . . . . . . 28

1.4 Main results . . . . . . . . . . . . . . . . . . . . . . . 32

1.5 Nominal wages and employment contracts . . . . . . . . . . . . . 37

1.6 Composition effects . . . . . . . . . . . . . . . . . . . . . 39

1.7 Heterogeneous effects . . . . . . . . . . . . . . . . . . 41

1.8 Final remarks . . . . . . . . . . . . . . . . . . . . . . . . . . . . . . 44

2 Does weather influence COVID-19 transmission? . . . . . . . . . 67

2.1 Introduction . . . . . . . . . . . . . . . . . . . 67

2.2 Data and empirical strategy . . . . . . . . . . . . . . . . . . . 69

2.2.1 Databases . . . . . . . . . . . . . . . . . . 69

2.2.2 Empirical strategy . . . . . . . . . . . . . . . . 75

2.3 Results . . . . . . . . . . . . . . . . . . . . 77

2.3.1 Main results . . . . . . . . . . . . . . 77

2.3.2 Heterogeneity: Different climates . . . . . . . . . . . . . . 81

2.3 .3 Summary of results . . . . . . . . . . . . . . . 86

2.3.4 Robustness checks . . . . . . . . . . . . . . 87

2.4 Discussion and policy implications . . . . . . . . . . . . . . . . . 91

3 Weather variations and impacts on mortality in Brazil . . . . . . . 107

3.1 Introduction . . . . . . . . . . . . . . . . . . . . 107

3.2 Data and empirical strategy . . . . . . . . . . . . . . 111

3.2.1 Mortality data . . . . . . . . . . . . . . . . . 112

3.2 .2 Weather data . . . . . . . . . . . . . . . . . . . 114

3.2 .3 Demographic variables . . . . . . . . . . . . . . . . 118

3.2.4 Empirical strategy . . . . . . . . . . . . . . . . . . . . 119

3.3 Results . . . . . . . . . . . . . . . . . . . . . . 121 
3.3.1 Main results . . . . . . . . . . . . . . . . . . . . . . 121

3.3 .2 Heterogeneities . . . . . . . . . . . . . . . . . 127

3.4 Final remarks . . . . . . . . . . . . . . . . . . . 135

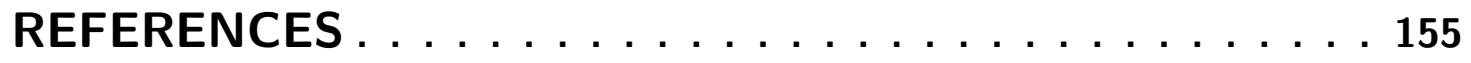




\title{
1 Do temperature shocks affect non-agriculture wages in Brazil? Evidence from individual-level panel data
}

\author{
With Jaqueline Olveira and Paula Pereda
}

\subsection{Introduction}

The link between temperature and economic outcomes in agricultural markets around the world and, in particular, in Brazil, has been the subject of much research. ${ }^{1.1}$ But despite Brazil's agriculture sector being of great relevance for the country's economy, the majority of its population lives in urban areas, and most of the country's labor force is employed in non-agriculture sectors. ${ }^{1.1 .2}$ A complete picture of the economic effects of temperature variations requires, therefore, the analysis of outcomes for those employed in non-agriculture activities. And yet, the empirical evidence on the existence and magnitude of such effects, especially using detailed individual-level data, is scant. ${ }^{1.1 .3}$ This study seeks to fill in this gap.

In this paper, we analyze the effects of short-term temperature shocks on Brazil's non-agricultural labor markets. In particular, we focus on individual wages.

\footnotetext{
${ }^{1.1 .1}$ Mendelsohn, Nordhaus e Shaw (1994) and Schlenker, Hanemann e Fisher (2005) use crosssectional data on land values to estimate climate effects on agriculture production. More recently, the literature uses panel data to identify temperature effects on agricultural profits/yields. See Deschenes e Greenstone (2007) and Schlenker e Roberts (2009) for U.S. and Schlenker e Lobell (2010), Feng, Krueger e Oppenheimer (2010) and Welch et al. (2010) for developing countries. For studies which focus on the Brazilian context, see Assad et al. (2004), Sun, Li e Ward (2007), Barbarisi et al. (2007), Assad et al. (2013) and Silva et al. (2019) for weather effects on specific crops, and Massetti et al. (2013), Araújo et al. (2014), Pereda e Alves (2018), Castro, Spolador e Marin (2019), and Oliveira e Pereda (2020) for weather and climate effects on agricultural outcomes.

1.1.2 Data from Brazilian Household Survey (2019) and Population Census (2010) reveal that $84.4 \%$ of Brazil's population lives in urban areas and $90 \%$ of the labor force is employed in non-agriculture sectors.

1.1.3 Dell, Jones e Olken (2014) review the empirical evidence on non-agricultural outcomes, such as labor productivity, migration and human health. The focus of these studies is mostly on human health. Most studies assess the effects of cold and heat on mortality rates, mainly for infants and the elderly Deschenes e Greenstone (2011), Barreca et al. (2015), Barreca et al. (2016), Burgess et al. (2017). See Deschenes (2014) for a review of the impacts of extreme temperatures on human health.
} 
To that end, we leverage rich data from administrative records covering the universe of Brazilian formal workers and their workplaces. After we draw a random sample from the universe, we end up with a panel of 222,174 workers for whom we observe monthly data on wages, hours worked, firm, sector and municipality of employment, and other labor market outcomes, covering January of 2015 through December of 2016. ${ }^{1.1 .4}$ We then merge daily weather data to the panel using information on workers' municipality of employment.

We argue that our panel data analysis based on monthly wage and weather data presents important advantages. As we show in Figure 1.3.1, there is considerable wage variation in our sample, both in nominal and real figures. ${ }^{1.1 .5}$ Thus, we would be missing much of the movement in wages that occurs within a year if we employed annual data instead. Furthermore, because we are interested in the short-term effect of temperature shocks, monthly data represent a more unexpected change to assess the consequences of extreme temperatures. ${ }^{1.1 .6}$ Finally, climate change is expected to increase unevenly across seasons in Brazil as winter temperatures might increase $1^{\circ} \mathrm{C}$ more than summer temperatures between 2070-2099. ${ }^{1.1 .7}$ The data, therefore, allow us to explore differential effects by month and understand future changes in weather at a finer level of disaggregation.

We present estimates of the impact of monthly temperature deviations from the monthly climate temperatures (i.e. historical averages) on individual-level hourly wages after including municipality-year, month, worker, and firm fixed effects. Our specification accounts for potential non-linearities by allowing for the

\footnotetext{
${ }^{1.1 .4}$ We choose 2015 and 2016 because these are the years when monthly wage data are available and can be matched to monthly weather data at the municipality level.

${ }^{1.1 .5}$ Nearly $70 \%$ of the month-to-month percent change in wages is different from zero and, among non-zero changes, close to $80 \%$ lies in the $-20.8 \%$ and $+29.9 \%$ range.

1.1.6 Many papers of the literature on weather effects on infant health normally use monthly or bi-monthly panel data Barreca (2012), Wilde, Apouey e Jung (2017), Banerjee e Maharaj (2020). Jacob, Lefgren e Moretti (2007) and Ranson (2014) explore monthly and weekly panels to investigate the weather (temperature and/or precipitation) effect on criminality rates in the United States.

1.1.7 While summer temperatures might increase from $2.3^{\circ} \mathrm{C}$ to $3.9^{\circ} \mathrm{C}$ between $2070-2099$ depending on the Brazilian region, winter temperatures can rise from $3.3^{\circ} \mathrm{C}$ to $4.9^{\circ} \mathrm{C}$ during the same period in the most pessimistic scenario. The calculations are based on CPTEC/INPE (Center for Weather Forecasting and Climate Studies of the National Institute for Space Research) forecasts for the A2 scenario by comparing 2070-2099 average with 1980-2010 average.
} 
effects to depend on the levels of municipalities' monthly climate temperatures. We find that in places and months where climate temperatures are below $18^{\circ} \mathrm{C}$, a $1^{\circ} \mathrm{C}$ temperature shock increases wages; for temperatures above the $18^{\circ} \mathrm{C}$ threshold, on the other hand, we estimate significant negative effects on wages from the same increase. Taking the extreme case of climate temperatures around $30^{\circ} \mathrm{C}$, for example, our estimate points to a $0.96 \%$ reduction in wages resulting from $1{ }^{\circ} \mathrm{C}$ shocks. When we calculate the marginal effect of sustained $1^{\circ} \mathrm{C}$ shocks each month across the climate temperature distribution over the year 2015, our results show that hourly wages fall $0.42 \%$ on average. This figure corresponds to annual income losses for workers in the formal sector of US\$ 1.1 billion, which is equivalent to $0.06 \%$ of Brazil's GDP in 2015.

Uncomfortably high or low temperatures may lead to harmful workplace environments, especially for workers performing their jobs outdoors or in non-climatecontrolled facilities Ramsey (1995), Pilcher, Nadler e Busch (2002), Seppänen, Fisk e Lei (2006). If labor supply is inelastic in the short-run, worker productivity losses could result in lower short-term wages in labor markets featuring predominantly temporary employment. Because our study focuses on formal labor markets characterized by long-term employment contracts, however, a more plausible explanation for our results could be that workers and firms engage in (implicit) risk-sharing labor contracts where workers accept lower nominal wages to avoid layoffs Franklin e Labonne (2019). Therefore, we look at other employment outcomes to shed light on whether employment contracts are affected by transitory temperature shocks and we find no effect on workers switching to temporary contracts or other payment schemes. ${ }^{1.1 .8} \mathrm{We}$, therefore, conclude that any adjustment to employment contracts is likely done through wages, since we do find significant effects on nominal wages.

Another concern we face is that weather shocks could have affected individual's labor market mobility. If workers respond to temperature shocks by migrating out of their current municipality, changing sectors, or switching employers, any temperature-wage relationship estimated from municipality-level data could be reflecting changes in job types and labor force composition. Because our analysis exploits a rich panel data on individuals and firms, we can empirically check for

${ }^{1.1 .8}$ The majority of workers were permanent (98\%) and under a monthly payment scheme (93\%). 
this mechanism. Our estimates indicate that there is a significant impact on the likelihood an individual changes sector or firm, but not municipality. We do not believe, however, that these changes explain the wage effects we find for two reasons. First, the percent of workers that changed sector or firms within the period we study is very small (4\% and 9\%, respectively). Second, our estimates remain unchanged when we estimate the effects on a sample of workers that never moved. Finally, and more importantly, the estimates with and without worker and firm fixed effects differ very little. We take this as suggestive evidence that these transitions have a limited role in explaining our results.

Because our premise is that harmful labor productivity effects from extreme temperatures is what drive the link between temperature and wages, it is reasonable to ask whether workers are affected differently depending on the degree to which they are exposed to the weather when performing their jobs. While we do not have direct data on workplace characteristics, we rely on detailed information on workers' occupation to classify them into "exposed" and "less exposed" groups. The estimates are only significant among "exposed" workers.

This paper contributes to the strand of the literature that studies wage adjustments to transitory economic and environmental shocks Jayachandran (2006), Kaur (2019), Franklin e Labonne (2019). ${ }^{1.1 .9}$ More closely related to our setting, and also exploiting individual-level data, Franklin e Labonne (2019) find that, in Filipino non-agriculture labor markets, nominal wages adjust downwards in response to a large environmental shock, typhoons. In line with their findings, our paper offers support for nominal wage flexibility in the context of labor markets characterized by long-term employment contracts. What sets us apart, however, is that we show evidence of wage adjustments in response to a smaller and more commonplace shock, short-term temperature increases. Furthermore, our ability to capture heterogeneous impacts along the distribution of climate temperatures helps to shed light on how climate change may affect the magnitude of wage adjustments to short-term temperature shocks.

1.1.9 See also Zivin e Neidell (2014), Deryugina e Hsiang (2014), Dell, Jones e Olken (2014), Barreca et al. (2016) and Behrer e Park (2017) for how climate change and weather impacts other labor market outcomes. 
This paper also dialogues with the literature that investigates the link between temperature and labor productivity in non-agriculture sectors for developing countries Zhang et al. (2018), Somanathan et al. (2018), Cai, Lu e Wang (2018), Chen e Yang (2019), Adhvaryu, Kala e Nyshadham (2020), Colmer (2020). The empirical studies in this literature employ actual measures of worker output and can provide more direct evidence of the negative impacts of extreme temperatures on worker performance. We contribute to this literature by providing evidence that the adverse effects on performance may translate into lower individual incomes, even when temperature increases are temporary. Our analysis also covers a wider range of economic sectors and regional climates, as we focus on the universe of Brazilian formal workers.

This paper is organized as follows. Section 1.2 outlines our empirical strategy and discusses identification of temperature effects from individual-level panel data. Section 1.3 describes the monthly wage and weather data. Section 1.4 presents our main results on the temperature-wage relationship. Sections 1.5, 1.6 and 1.7 discuss additional results, robustness checks, and heterogeneous effects. Section 1.8 offers some big-picture insights drawn from our results. 


\subsection{Empirical approach}

To understand the impacts of weather and climate on economic outcomes, the standard panel approach typically distinguishes weather from climate impacts. A weather variable is a realization from a climate distribution. As Dell, Jones e Olken (2012) highlight, weather variables have strong identification properties. On the other hand, climate effects are difficult to identify since climate variables are time-invariant and, therefore, dropped from the estimates when we include individual or regional fixed effects.

We choose to identify temperature effects by employing a temperature deviation variable - the monthly temperature deviation from the historical average - and its interaction with the historical average (or climate). The temperature deviation measures short-term temperature shocks. And because our estimation rests on monthly temperature variation as an identifying source, we ultimately rely on the short-term weather unpredictability for causal inference.

The temperature shock interaction with the climate variable allows for the effects to depend on the baseline climate. This means, for example, that one-degree changes in temperature deviations from climate averages may have a different impact on colder places (or colder seasons) than on warmer places (or warmer seasons). The goal is to distinguish the temperature effects in hotter places, when climate temperatures are already high, from the effects in colder places. To that end, we propose the following model:

$\log$ wage $_{i f c m t}=\alpha_{0}+\alpha_{1} \Delta T e m p_{c m t}+\alpha_{2} \Delta T e m p_{c m t} * \bar{T}_{c m}+\beta Z_{c m t}+\alpha_{i}+\alpha_{f}+\alpha_{m}+\alpha_{c t}+\epsilon_{i f c m t}$,

where wage $e_{\text {ifcmt }}$ is the real hourly wage of worker $i$ employed by firm $f$ located in municipality $c$ in month $m$ of year $t ; \Delta T e m p_{c m t}=\left(T e m p_{c m t}-\bar{T}_{c m}\right)$ denotes the temperature deviation from the climate temperature in municipality $c$ in month $m$ of year $t$, and $\bar{T}_{c m}$ is the municipality's climate temperature in month $m .^{1.2 .1}$ We also include controls for precipitation $\left(Z_{c m t}\right)$ and use the same functional

${ }^{1.2 .1}$ We calculate the climate temperature as the long-term temperature for a given month in each municipality. We do this by taking the average of the month over the entire period of historical weather data, from 1980 to 2016. 
form as we use for temperature. The remaining parameters, $\alpha_{i}, \alpha_{f}, \alpha_{m}$, and $\alpha_{c t}$, denote worker, firm, month, and municipality-year fixed effects, respectively; $\epsilon_{i f c m t}$ is the idiosyncratic error term. These fixed effects are key for identifying the short-term causal effects of temperature on wages. First, municipality-year fixed effects hold constant time-invariant municipality attributes, such as historical and cultural determinants of regional economic development, which are correlated with long-term climate; they also absorb annual shocks to local labor markets that are potentially associated with climate conditions. Month fixed effects are key to control for weather seasonality that may coincide with economic seasonality that causes labor markets to be more active. Individual fixed effects allow us to account for changes in workforce skill composition, both observed and unobserved, spurred by weather shocks within a municipality. Firm fixed effects help us control for firmlevel unobservable characteristics such as endogenous adoption of climate-control technology, as well as changes in the sector/industry mix within a municipality.

In addition to the average temperature and its monthly deviations to examine the effects of temperature on wages, we adopt an approach based on temperature bins, first employed by Deschenes e Greenstone (2011). The idea is to consider how often temperatures fall into specific ranges. Despite being more flexible than other functional forms, this approach can be arbitrary when defining the bins' ranges, and might lead to biased estimates depending on how data is aggregated Dell, Jones e Olken (2012). We choose the bins specification below:

$\log$ wage $_{i f c m t}=\beta_{0}+\sum_{j=1}^{8} \beta_{j} \operatorname{Temp}_{c m t}^{j}+\sum_{h=1}^{9} \beta_{h} \operatorname{Rain}_{c m t}^{h}+\alpha_{i}+\alpha_{f}+\alpha_{m}+\alpha_{c t}+\epsilon_{i f c m t}$,

where $T e m p_{c m t}^{j}$ is the number of days in municipality $c$, month $m$ of year $t$ that fall in temperature bin $j$. $\operatorname{Rain}_{c m t}^{j}$ is the number of days in municipality $c$, month $m$ of year $t$ that fall in precipitation bin $j$. We employ the following temperature bins: below $12^{\circ} \mathrm{C} ; 12$ to $15^{\circ} \mathrm{C} ; 15$ to $18^{\circ} \mathrm{C} ; 18$ to $21^{\circ} \mathrm{C} ; 21$ to $24^{\circ} \mathrm{C}$ (base category); 24 to $27^{\circ} \mathrm{C} ; 27$ to $30^{\circ} \mathrm{C}$; and above $30^{\circ} \mathrm{C} .{ }^{1.2 .2}$ The set of fixed effects are the same

\footnotetext{
${ }^{1.2 .2}$ For precipitation, we employ the following bins: $0 \mathrm{~mm} ; 0$ to $0.05 \mathrm{~mm} ; 0.05$ to $0.26 \mathrm{~mm} ; 0.26$ to $0.8 \mathrm{~mm}$; 0.8 to $1.8 \mathrm{~mm} ; 1.8$ to $3.6 \mathrm{~mm}$ (base category); 3.6 to $6.7 \mathrm{~mm} ; 6.7$ to $12.8 \mathrm{~mm}$; and above $12.8 \mathrm{~mm}$. We set the first precipitation bin to $0 \mathrm{~mm}$ because around $21 \%$ of the precipitation values in our sample are zero; we separate the other eight bins (to match temperature bins) so that
} 
as in Equation (3.2.1).

Finally, we use harmful degree days (HDD) ${ }^{1.2 .3}$ to capture the effect of extreme hot temperatures on wages according to the equation below:

$$
\log \text { wage }_{\text {ifcmt }}=\gamma_{0}+\gamma H D D_{c m t}+\beta Z_{c m t}+\alpha_{i}+\alpha_{f}+\alpha_{m}+\alpha_{c t}+\epsilon_{i f c m t},
$$

where $H D D_{c m t}$ is the sum of variable $H D D_{d c m t}$ in month $m$ of year $t$. $H D D_{d c m t}$ counts the degree days above an specific threshold $\left(30^{\circ} \mathrm{C}\right)^{1.2 .4}$ in month $m$ of year $t$ :

$$
\begin{aligned}
H D D_{d c m t} & =\left(T_{d c m t}-30\right), \text { if } T_{d c m t}>30 \\
& =0, \text { if } T_{d c m t} \leq 30,
\end{aligned}
$$

where $T_{d c m t}$ is the observed temperature on day $d$ (of month $m$ of year $t$ ) in municipality $c$.

To estimate the parameters from Equations (3.2.1), (1.2.2), and (1.2.3) we utilize administrative employer-employee panel data on labor market outcomes, where information on wages is available on a monthly basis, and municipality-level monthly weather data. The next section describes the data sources and summarizes the variables of interest.

\subsection{Wage and weather data}

\subsubsection{Employer-employee panel}

We source worker-level data on monthly wages from RAIS (Annual Social Information Report), which is an employer-employee administrative database covering $99 \%$ of the formal labor force, starting in January of 2015 and ending in

every bin had approximately the same number of observations.

${ }^{1.2 .3}$ See Schlenker, Hanemann e Fisher (2006) for an application using harmful degree days for agriculture, and Jessoe, Manning e Taylor (2018) and Liddle (2018) for applications in nonagricultural markets. Harmful degree days is also referred in the literature as killing degree days Butler e Huybers (2013), Butler e Huybers (2015).

${ }^{1.2 .4} \mathrm{We}$ also explore the threshold of $29^{\circ} \mathrm{C}$ as a robustness check. Precipitation controls in the HDD exercise are the same as in our main exercise (Equation 3.2.1). 
December of $2016 .^{1.3 .1}$ We draw a random sample of $1 \%$ of the universe of workers and match them with weather information using the municipalities where the job is performed. We also restrict our sample to workers aged 25 to 55 and exclude workers in public administration and military occupations. Our final estimation sample has $3,685,235$ worker-month observations representing 222,174 workers. ${ }^{1.3 .2}$

We calculate hourly wages as the ratio between monthly wages and monthly hours of work in the main occupation. ${ }^{1.3 .3}$ To create a measure of real wages (base month-year is January of 2015), we deflate nominal wages using the Brazilian official consumer price index (IPCA) by month, calculated by the Brazilian Institute of Geography and Statistics (IBGE).

Aside from hourly wages, we also use data on other worker's outcomes, such as: contractual hours per month, days on leave in the month, employment status (permanent vs. temporary) and payment scheme (monthly vs other forms) to investigate possible effects of temperature shocks on employment contracts; data on firm sector, municipality and firm identification of current employment to study labor market mobility; and education (years of schooling) and occupation data to check for heterogeneous effects across workers in occupations more or less dependent on degree of exposure to climate effects.

Table 1.3.1 presents descriptive statistics of workers from our estimating sample. The average hourly nominal wage is $13.43 \mathrm{BRL} /$ hour (or approximately $3.32 \mathrm{USD} /$ hour) and the average hourly real wage is 12.35 (or $3.09 \mathrm{USD} /$ hour). ${ }^{1.3 .4}$ Individuals work on average 43 hours per week in permanent jobs ( $98 \%$ of the sample) and $93 \%$ of them receive monthly wages (instead of weekly or daily). In our sample, workers missed on average 0.33 working days in a month. In regard

\footnotetext{
1.3.1 The panel starts in 2015 because it is the first year that RAIS provides monthly wage data. It ends in 2016 because the daily weather data is available up to that year.

${ }^{1.3 .2} \mathrm{We}$ also lose some workers due to the many levels of fixed effects we include in the analysis. For more details about the sampling process, see section A.1. of the Appendix.

1.3.3 The monthly wage includes labor income, tips, payment for performance, commission fees, additional gratifications from tenure, labor prizes, additional vacation pay, allowances of any kind, value-worked notice, overtime pay or premiums, premium for unhealthy services (even if temporary), food stamps, maternity/paternity leave wage and student scholarships.

${ }^{1.3 .4}$ Exchange rate was $1 \mathrm{BRL} \approx 0.25 \mathrm{USD}$ on December 31,2015 . Source: International Monetary Fund (IMF).
} 
to education, individuals have on average 11.3 years of schooling ${ }^{1.3 .5}$ and most are employed in low-skilled sectors (24\%). Only $7 \%$ of the workers are employed in high-skilled occupations. ${ }^{1.3 .6}$

The table also shows numbers that characterize the panel dimension of the data. Information on wages is available for an average of 16.59 months (out of 24). Wages rose 5.79 times on average in the two-year period, and fell 5.54 times on average over the course of 2015-2016, which may suggest that there is more downward than upward rigidity in wages. We also learn that in the two-year period only $3 \%$ of workers changed municipalities, $4 \%$ changed sector of employment, and $9 \%$ switched employers. These low numbers are not surprising given the short time frame our study covers.

As the majority of our sample of formal workers is employed in permanent jobs, we ask how much monthly wages vary within our two-year time span. Figure 1.3.1 shows the distribution of the variation (in \%) of nominal and real wages between consecutive months from January 2015 to December 2016. The left figures consider the full distribution, while the right figure excludes the observations whose wages do not vary. We observe a spike around zero: $30 \%$ of nominal wages do not change and $10 \%$ change very little. Excluding zero variations (right figure), the $10^{t h}$ and $90^{t h}$ percentiles of the distribution are $-20.8 \%$ and $29.9 \%$. These numbers demonstrate that there is a considerable amount of month-to-month variation in nominal wages. The variation in real wages is even larger because monthly inflation rates are always positive over the period we analyze. ${ }^{13.7}$

We also observe that only a small fraction of the workers in our estimation sample did not experience changes in nominal wages (4,967 workers or $2.2 \%)$, while workers whose nominal wages changed every month make up $12.9 \%$ of the sample $(28,576$ workers). The deflation of wages naturally "creates"small variations in real

\footnotetext{
1.3.5 In Brazil, 12 years of schooling are needed to complete high-school education.

${ }^{1.3 .6}$ We define low-skilled occupations as those in the bottom $25^{t h}$ percentile of the wage and education distributions across all occupations, and high-skilled occupations those in the top $25^{\text {th }}$ of both distributions. In our estimating sample, workers employed in low-skilled occupations have, on average, 9.5 years of schooling, which is elementary school education. Workers on high-skilled occupations have 15.7 years of formal education, or college education.

1.3.7 (KAUR, 2019) finds similar figures when analyzing Indian labor markets.
} 
Table 1.3.1 - Sample of employees in the formal labor force

\begin{tabular}{lcc}
\hline \hline & Mean & Std. Dev. \\
\hline & & \\
General information & & \\
Nominal hourly wages (BRL/hour) & 13.43 & 17.72 \\
Real hourly wages (BRL/hour, January of 2015) & 12.35 & 16.24 \\
Years of schooling & 11.26 & 3.07 \\
Contractual hours (per week) & 42.76 & 3.43 \\
Days on leave & 0.33 & 1.77 \\
Proportion of workers with a permanent job & 0.98 & \\
Proportion of worker that receive a monthly payment & 0.93 & \\
& & \\
Occupations/Sectors & & \\
Proportion of workers with Low Skilled Occupations & 0.24 & \\
Proportion of workers with High Skilled Occupations & 0.07 & \\
& & \\
Panel information & & \\
Average number of times workers changed municipality & 0.03 & 0.19 \\
Average number of times workers changed sector & 0.04 & 0.20 \\
Average number of times workers changed employer & 0.09 & 0.32 \\
Average number of months with wage data & 16.59 & 7.52 \\
Average number of times wages rose & 5.79 & 4.11 \\
Average number of times wages fell & 5.54 & 3.60 \\
\hline \hline
\end{tabular}

Notes: Table presents summary statistics of selected variables calculated for the 222,174 workers in our estimation sample. Real hourly wages are in Jan 2015 figures. Data source: RAIS 2015-2016.

wages even when nominal wages were constant, which explains a larger fraction of workers whose real wages changed every month. ${ }^{1.3 .8}$

\footnotetext{
1.3.8 Appendix Table 1.8.1 presents the distribution of workers across the number of times wages changes between two consecutive months from January 2015 to December 2016.
} 
Figure 1.3.1 - Percentage monthly variation in nominal and real wages
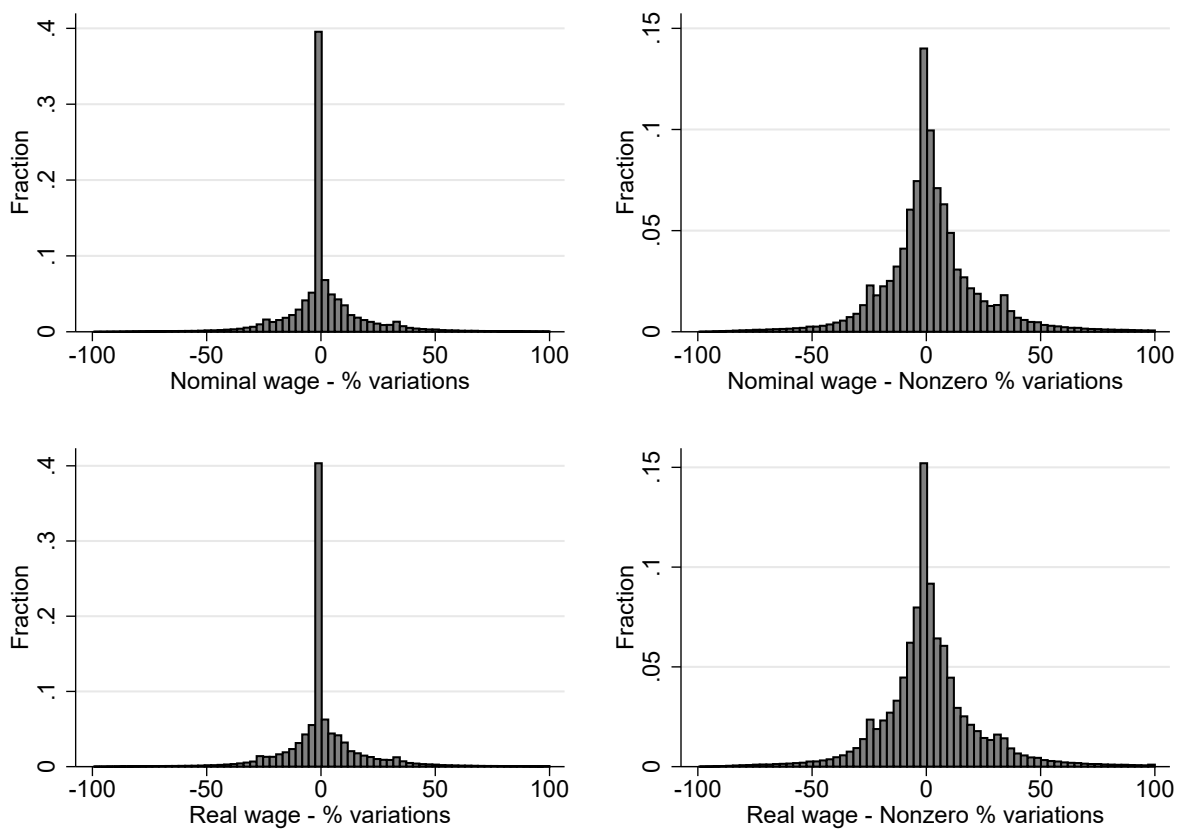

Notes: Figure shows the distribution of percent monthly changes in nominal and real wages for our estimating sample. We calculate changes between consecutive months only, ignoring missing values. Left figures include cases where percent variation in nominal wages are zero, whereas the Right figures exclude those cases. Data source: RAIS 2015-2016

\subsubsection{Monthly weather data}

To calculate temperature changes by month, we use daily weather data generated by (XAVIER; KING; SCANLON, 2017). ${ }^{13.9}$ The authors use historical weather observations collected from rain gauges and weather stations from the 'Instituto Nacional de Meteorologia' (INMET), the 'Agência Nacional de Águas' (ANA), and 'Departamento de Águas e Energia Elétrica de São Paulo' (DAEE).

${ }^{1.3 .9}$ An update of (XAVIER; KING; SCANLON, 2016). The authors compare six different techniques of data interpolation by using data from 3,625 rain gauges (for rainfall) and 735 weather stations (for temperatures). They conclude that the inverse distance weighting and angular distance weighting interpolation techniques are the best way of interpolating stations/rain gauges to the whole Brazilian territory. We use the interpolated data that performed better in their tests. 
Temperature is available for all Brazilian territory starting in January of 1980 and ending in June of 2017 and precipitation is available from January of 1980 to December of 2016 . The spatial resolution of the data is $0.25^{\circ} \times 0.25^{\circ}$, resulting in 27,216 grids.

We convert grid-level data to municipality-level data as follows. For latitudelongitude pairs which fell inside a municipality's boundaries, we consider the municipality weather as the average weather values of those grids. When latitudelongitude pairs did not belong to the municipality polygon, we attribute the closest grid to the municipality centroid within a $0.5^{\circ}(\sim 55 \mathrm{~km})$ range. Based on these assumptions we were able to match weather data for 3,226 municipalities in the country, representing 137 million people, or about $67 \%$ of the country's population in 2015. ${ }^{1.3 .10}$ In this sense, rural and more remote areas of the country are being excluded from our database as they are distant to weather stations and, therefore, we do not observe their accurate weather data. We believe this is not a problem for estimations as these municipalities usually have small labor markets (particularly for formal workers) and we do not believe weather affects these municipalities differently from larger ones.

After we assign daily grid-level data to each municipality, we calculate monthly averages, Temp $p_{c m t},{ }^{1.3 .11}$ for our sample years, 2015-2016, by taking a simple mean of the daily observations throughout the month by municipality. We then calculate the long-run average (climate measure) over the 1980-2016 period for each month and municipality, $\bar{T}_{c m}$, so we can construct the variables of Equation (3.2.1). ${ }^{1.3 .12}$ Figure 1.3.2 shows the distribution of our main temperature variable, monthly temperature deviations from climate temperatures $\left(\Delta T e m p_{c m t}\right)$, after demeaning by municipality fixed effects, municipality and year fixed effects and municipality-year fixed effects. The figure shows we have variation to identify

\footnotetext{
1.3.10 Our actual estimation sample includes 2,829 municipalities that concentrate 133 million people ( $65 \%$ of the country's population in 2015$)$, as some small municipalities are excluded when we draw a random sample from our dataset. Appendix Figures 1.8.1 and 1.8.2 show that the distributions of weather and climate temperature in the full sample (3,226 municipalities) and in our estimation sample $(2,829$ municipalities $)$ are practically the same.

${ }^{1.3 .11}$ Temperature in municipality $c$ in month $m$ of year $t$.

${ }^{1.3 .12}$ We calculate the climate temperature (and precipitation) of month $m$ in a given municipality by taking the average monthly temperature of all $m$ months between 1980 and 2016 .
} 
temperature effects on wages even after we incorporate fixed effects. ${ }^{1.3 .13}$

Figure 1.3.2 - Residual variation in temperature deviations $\left(\Delta T e m p_{c m t}\right)$

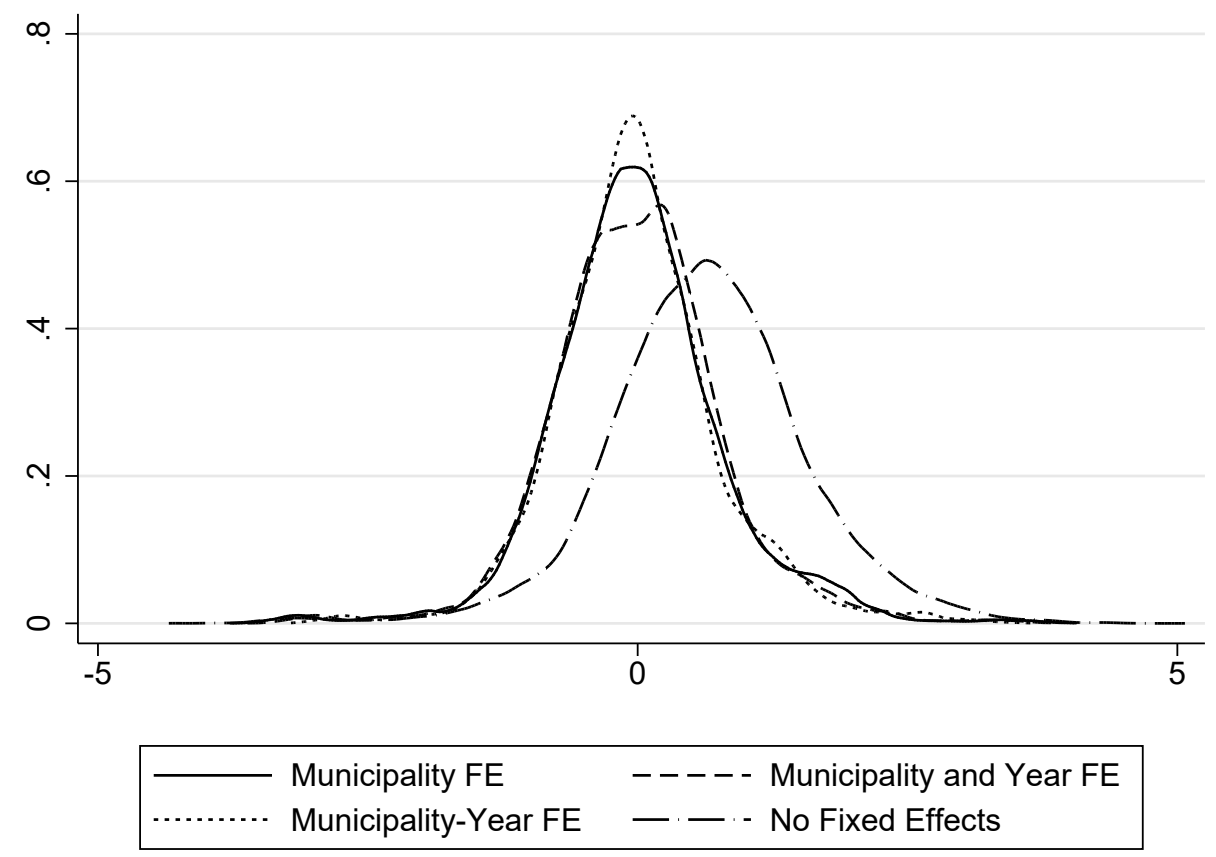

Notes: Figure displays the residuals from regressions of $\Delta T e m p_{c m t}$ on municipality fixed effects, municipality and year fixed effects, and municipality-year fixed effects, respectively. The $\Delta T e m p_{c m t}$ itself is also depicted for comparison under the legend "No Fixed Effects". Data source: (XAVIER; KING; SCANLON, 2017), 1980-2016.

Because deviations are calculated as the monthly difference between weather and climate, a negative (positive) value means that the month was colder (hotter) than the monthly climate. Temperature deviations in 2015-2016 range from $-4^{\circ} \mathrm{C}$ to $+5^{\circ} \mathrm{C}$. Around $98 \%$ of the distribution is concentrated in the $-2^{\circ} \mathrm{C} /+3^{\circ} \mathrm{C}$ interval. Appendix Table 1.8.2 and Appendix Figure 1.8.3 present further temperature and climate temperature statistics for the municipalities in our estimating sample. The temperature distributions are negatively skewed because most of the Brazilian territory is located in Equatorial or Tropical climates. Temperatures between 2015

1.3.13 Appendix Table 1.8.2 also presents summary statistics for the other weather variables we use in Equation (1.2.2), temperature bins, and in Equation (1.2.3), Harmful Degree Days (HDD). 
and 2016 range from $+9^{\circ} \mathrm{C}$ to $+32^{\circ} \mathrm{C}$ and climate normals, calculated from 1980 to 2016 , vary less, from $+12^{\circ} \mathrm{C}$ to $+30^{\circ} \mathrm{C} \cdot{ }^{1.3 .14}$

\footnotetext{
1.3.14 Appendix Figures 1.8.4 and 1.8.5 present temperature bins and HDD distributions, respectively. About $99 \%$ of the HDD distributions lie between $0^{\circ} \mathrm{C}$ and $+45^{\circ} \mathrm{C}$ for the above $29^{\circ} \mathrm{C}$ version and between $0^{\circ} \mathrm{C}$ and $+19^{\circ} \mathrm{C}$ considering above $30^{\circ} \mathrm{C}$. As for the bins, only those three ranging from $+21^{\circ} \mathrm{C}$ to $+30^{\circ} \mathrm{C}$ are not positively skewed since this is the most common temperature range in the sample.
} 


\subsection{Main results}

We begin by presenting estimates of the parameters $\alpha_{1}$ and $\alpha_{2}$ from variants of Equation (3.2.1) in Table 1.4.1. Each column shows results for different sets of fixed effects. Standard errors are clustered by economic region. ${ }^{1.4}$ All the results point to the same general pattern: for places and months with lower climate temperatures, deviations form those temperatures are associated with higher hourly wages, whereas for places and month with higher climate temperature, the deviations are associated with lower hourly wages. The fixed effects, however, alter the magnitudes of these effects and also the temperature inflection point. ${ }^{1.4 .2}$ In particular, comparing columns (1) and (2), we see that adding municipality fixed effects considerably reduces the magnitude of the coefficients. For example, without any fixed effects one would conclude that, for climate temperatures around $30^{\circ} \mathrm{C}$, a one-degree increase in temperature would be associated with nearly $14 \%$ fall in hourly wages, whereas with municipality (and year) fixed effects, the same increase would be associated with a $0.41 \%$ fall in hourly wages. This sizable discrepancy showcases the importance of accounting for the correlation between temperatures and the determinants of economic activity at the local level. For example, colder municipalities in the country are in the richest South and Southeast regions, whereas the hotter municipalities are in the poorest North and Northeast.

A comparison between the results in columns (2) and (3) reveals further that month fixed effects are relevant to account for the potential correlation between weather and economic seasonality: the association between a one-degree deviation from climate temperatures at $30^{\circ} \mathrm{C}$ more than doubles $(-0.41 \%$ to $-0.95 \%)$. This could reflect, for example, that labor markets are normally more active during warmer seasons because of the holidays in the Southern hemisphere (e.g. Christmas, New Year's eve and Carnival happen during summer). In that case, the estimates without month fixed effects would be understating the effect of temperature on

\footnotetext{
${ }^{1.4 .1}$ IBGE classifies Brazilian municipalities according to their degree of economic influence, or poles of economic attraction ('Região de Influencia das Cidades' - REGIC). More details available from this link. We cluster the standard errors at the REGIC level.

1.4.2 Temperature inflection point is the average temperature after which the estimated marginal effects of weather shocks change signs, from positive to negative.
} 
wages at high climate temperatures.

The results from columns (4) through (6) show that adding firm and individual fixed effects makes little difference in the magnitudes of the estimates, suggesting that bias stemming from changes in the composition of jobs and workforce plays a limited role in our context. We cannot state, however, that composition bias is not a potential threat to identification of weather-economic relationships in general. We believe that it is particular to our setting because we are capturing short-term relationships, and there are very few observed moves in and out of jobs and municipalities from month to month in the period we analyze.

We present our preferred estimates in column (7), which reflect the whole set of fixed effects highlighted in Equation (3.2.1). Figure 1.4.1 shows marginal effects across different levels of climate temperatures. At climate temperatures below $16^{\circ} \mathrm{C}$, one-degree deviations have a positive but modest effect on hourly wages. ${ }^{1.4 .3}$ For temperatures above $18^{\circ} \mathrm{C}$, the signs reverse. Between $24^{\circ} \mathrm{C}$ and $30^{\circ} \mathrm{C}$, the marginal effects range from $-0.53 \%$ to $-0.96 \%$. To put this effect in perspective, the average monthly deviation in that temperature range for year 2015 in our dataset is $0.83^{\circ} \mathrm{C}$. That would correspond to a $-0.44 \%$ (and $-0.8 \%$ ) effect on wages attributed to monthly weather shocks at $24^{\circ} \mathrm{C}\left(30^{\circ} \mathrm{C}\right)$ average temperatures. ${ }^{1.4 .4}$

We now use our results to provide a measure of the average income losses from a sustained $1^{\circ} \mathrm{C}$ shock in all months of the year 2015. First, we calculate the predicted wage change for each worker in our sample based on the results from column (7), Table 1.4.1, and average it over the months. Real hourly wages, then, fall by $0.42 \%$. To provide an annual measure of the total income losses, we add the monthly predicted changes in real monthly wages across all months within our estimating sample, and arrive at in-sample losses of $\mathrm{R} \$ 17,854,976$ (US\$4,463,744) for the year 2015. Expanding these losses to the 56.5 million workers that make up

\footnotetext{
${ }^{1.4 .3}$ The effects we find using worker-level data are consistent with macro-level studies that find positive effect (or null effect) on income of an increase of $1^{\circ} \mathrm{C}$ in colder countries Dell, Jones e Olken (2012), Burke, Hsiang e Miguel (2015).

${ }^{1.4 .4}$ Our numbers are still lower (in module) than the findings in the literature when assessing a $1{ }^{\circ} \mathrm{C}$ increase in temperatures on industrial output Hsiang (2010), Zhang et al. (2018), Chen e Yang (2019) and on income in poor countries Dell, Jones e Olken (2012), Burke, Hsiang e Miguel (2015) or warmer seasons in the U.S. Deryugina e Hsiang (2014).
} 
Brazil's formal labor markets corresponds to nearly $\mathrm{R} \$ 4.5$ billion in real income losses. That is equivalent to US\$ 1.1 billion, or $0.06 \%$ of the GDP. ${ }^{1.4 .5}$

We repeat the exercise described above but now assuming that the climate temperatures (that is, $\bar{T}_{c m}$ ) have uniformly increased by $2^{\circ} \mathrm{C}$ to reflect climate change predictions Guivarch e Hallegatte (2013), Kwok et al. (2018). We conclude that under that scenario, real hourly wage would be $2.04 \%$ lower. Calculated for our estimating sample, the losses in annual income would amount to $\mathrm{R} \$ 85,971,712$ (US\$ 21,492,928). Applying these losses to the universe of formal workers would lead to $\mathrm{R} \$ 21.9$ billion in annual income losses. This figure corresponds to US\$ 5.5 billion, or $0.30 \%$ of the GDP in 2015 .

Table 1.4.1 - Temperature shocks and real hourly wages

\begin{tabular}{|c|c|c|c|c|c|c|c|}
\hline & (1) & $(2)$ & (3) & (4) & (5) & (6) & (7) \\
\hline$\Delta T e m p$ & $\begin{array}{l}0.23235^{* * *} \\
(0.06769)\end{array}$ & $\begin{array}{c}0.00790^{* *} \\
(0.00346)\end{array}$ & $\begin{array}{l}0.01212^{* * *} \\
(0.00231)\end{array}$ & $\begin{array}{l}0.01045^{* * *} \\
(0.00202)\end{array}$ & $\begin{array}{l}0.01104^{* * *} \\
(0.00194)\end{array}$ & $\begin{array}{l}0.01092^{* * *} \\
(0.00198)\end{array}$ & $\begin{array}{l}0.01192^{* * *} \\
(0.00146)\end{array}$ \\
\hline$(\Delta T e m p) \cdot \bar{T}$ & $\begin{array}{l}-0.01228^{* * *} \\
(0.00325)\end{array}$ & $\begin{array}{l}{ }^{k}-0.00040^{* *} \\
(0.00017)\end{array}$ & $\begin{array}{l}-0.00072^{* * *} \\
(0.00010)\end{array}$ & $\begin{array}{l}{ }^{*}-0.00062^{* * *} \\
(0.00009)\end{array}$ & $\begin{array}{l}-0.00066^{* * *} \\
(0.00009)\end{array}$ & $\begin{array}{l}-0.00065^{* * *} \\
(0.00009)\end{array}$ & $\begin{array}{l}-0.00072^{* *} \\
(0.00007)\end{array}$ \\
\hline R-squared & 0.00607 & 0.00002 & 0.00003 & 0.00008 & 0.00024 & 0.00027 & 0.00032 \\
\hline Obs. & $3,685,235$ & $3,685,235$ & $3,685,235$ & $3,685,235$ & $3,685,235$ & $3,685,235$ & $3,685,235$ \\
\hline Workers & 222,174 & 222,174 & 222,174 & 222,174 & 222,174 & 222,174 & 222,174 \\
\hline Mean of dep. var. & 13.34 & 13.34 & 13.34 & 13.34 & 13.34 & 13.34 & 13.34 \\
\hline Temp. Inv. $\left({ }^{\circ} \mathrm{C}\right)$ & 18.9 & 19.7 & 16.8 & 16.8 & 16.8 & 16.8 & 16.6 \\
\hline Worker FE & No & No & No & No & Yes & Yes & Yes \\
\hline Firm FE & No & No & No & Yes & No & Yes & Yes \\
\hline Municipality FE & No & Yes & Yes & Yes & Yes & Yes & No \\
\hline Year FE & No & Yes & Yes & Yes & Yes & Yes & No \\
\hline Month FE & No & No & Yes & Yes & Yes & Yes & Yes \\
\hline Municipality-Year FE & No & No & No & No & No & No & Yes \\
\hline
\end{tabular}

Notes: Table shows estimates of versions of Equation (3.2.1) for different sets of fixed effects. Dependent variable is the log of real hourly wages. Wages are monthly deflated for January, 2015. Temperature is included in the model as deviations from climate temperature $(\Delta T e m p)$ and its interaction with climate temperature $((\Delta T e m p) \cdot \bar{T})$. All regressions include precipitation variables as controls and standard errors are clustered by economic region. "Temp. Inv. $\left({ }^{\circ} \mathrm{C}\right)$ " is the temperature inflection point, which is the $\bar{T}$ that makes $\frac{\partial}{\Delta T e m p}\left[\hat{\alpha}_{1} \Delta T e m p+\hat{\alpha}_{2}(\Delta T e m p) \cdot \bar{T}\right]=0$. Data sources: labor market data from RAIS 2015-2016 and weather data from Xavier, King e Scanlon (2017).

In what follows, we ask if our main results stand when we employ alternative specifications for weather shocks. Figure 1.4.2 presents estimates from temperature

\footnotetext{
1.4.5 Brazilian GDP in 2015 was US\$ 1.8 trillion. Source: World Bank.
} 
Figure 1.4.1 - Marginal effects of $1^{\circ} \mathrm{C}$ shock on log of real hourly wages
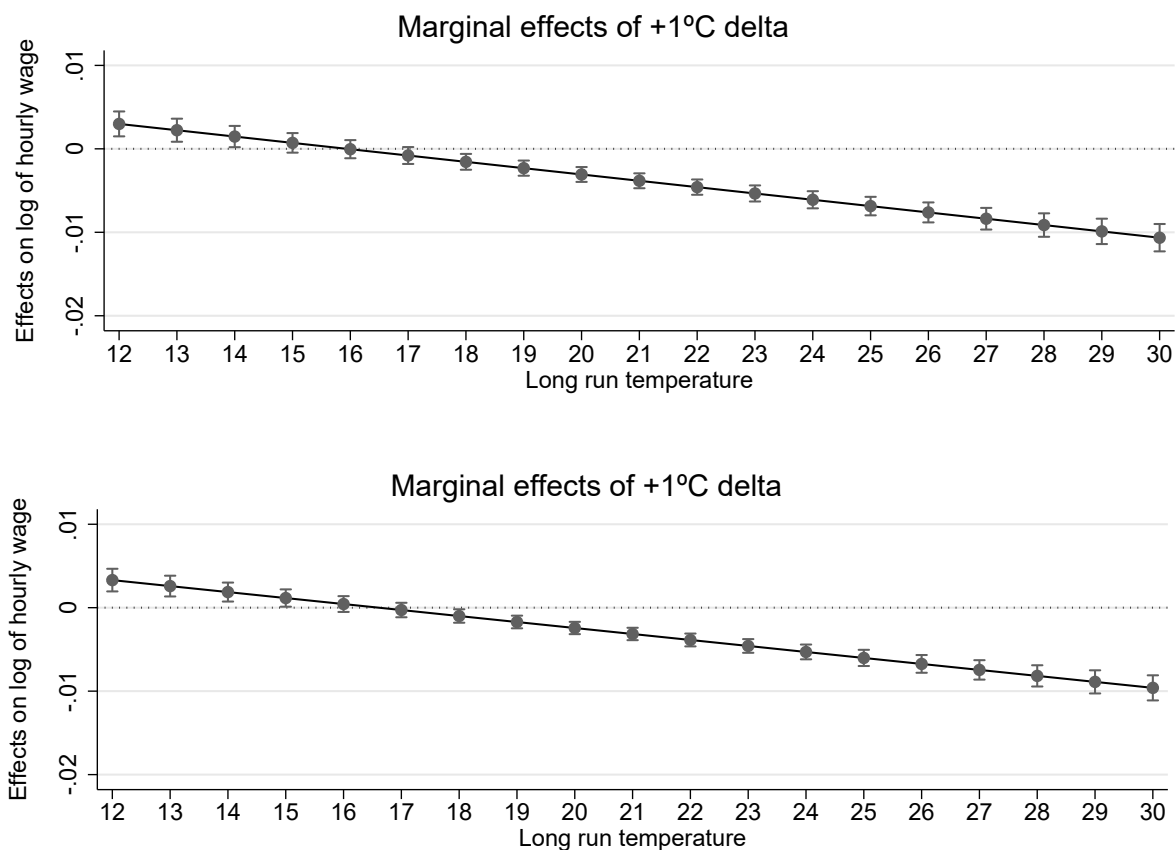

Notes: Figures show marginal effects of $1^{\circ} \mathrm{C}$ temperature shock on the log of real hourly wages for different levels of climate temperature $(\bar{T})$. Top figure refers to column 3 of Table 1.4.1, which uses municipality, year and month fixed effects. The bottom figure refers to column 7 of Table 1.4.1, which adds worker and firm fixed effects and swaps municipality and year by municipality-year fixed effects. Data sources: labor market data from RAIS 2015-2016 and weather data from Xavier, King e Scanlon (2017).

bins described in Equation (1.2.2). These results confirm our main findings: extreme hot temperatures have adverse effects on wages. More specifically, an additional day in the month that falls in the above $30^{\circ} \mathrm{C}$ bin, instead of the $21-24^{\circ} \mathrm{C}$ bin, results in a $0.1 \%$ reduction in hourly wages; an additional day in the $27-30^{\circ} \mathrm{C}$ bin also has a negative effect on wages, although much smaller, $0.05 \%$. It is worth pointing out that increases in the number of days in lower temperature bins could have a modest adverse impact on wages, although the evidence is not conclusive given that the coefficients are not statistically significant.

Finally, in Table 1.4 .2 we attempt to capture the impact of extremely hot temperatures using HDD, the number of degree-days with temperatures above $30^{\circ} \mathrm{C}$. 
We also present results for the $29^{\circ} \mathrm{C}$ threshold. Once again, the estimates confirm our previous findings. An additional degree-day above $30^{\circ} \mathrm{C}$ results in hourly wages $0.047 \%$ lower; the effect is somewhat smaller if we consider the $29^{\circ} \mathrm{C}$ threshold: a $0.033 \%$ reduction.

Overall, the evidence from three different weather specifications indicates that hourly wages are negatively impacted by extreme (mostly hot) temperatures. In the sections that follow, we investigate the possible mechanisms connecting short-term changes in temperature and wages in Brazil.

Figure 1.4.2 - Temperature shocks and real hourly wages, alternative specification - Temperature Bins

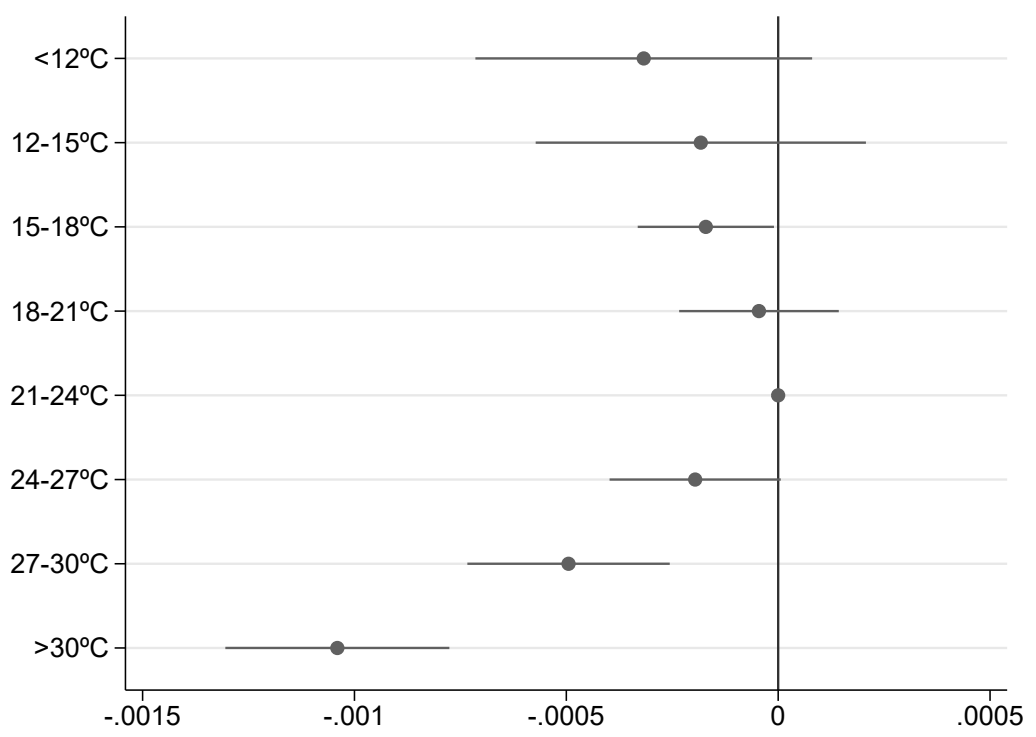

Notes: Figure shows estimates from Equation 1.2.2. We use our preferred specification, which includes worker, firm, month and municipality-year fixed effects. Temperature bins range from below $12^{\circ} \mathrm{C}$ to above $30^{\circ} \mathrm{C}$ in sets of $3^{\circ} \mathrm{C}$. The $21-24^{\circ} \mathrm{C}$ bin is the base category. Regression includes precipitation bins as controls and standard errors are clustered by economic region. Appendix Table 1.8.3 shows the estimation results. Data sources: labor market data from RAIS 2015-2016 and weather data from Xavier, King e Scanlon (2017). 
Table 1.4.2 - Temperature shocks and real hourly wages, alternative specification - Harmful Degree Days (HDD)

\begin{tabular}{lcc}
\hline \hline & $(1)$ & $(2)$ \\
& Log of hourly wage & Log of hourly wage \\
\hline HDD 30+ & $-0.00047^{* * *}$ & \\
& $(0.00010)$ & \\
HDD 29+ & & $-0.00033^{* * *}$ \\
& & $(0.00006)$ \\
\hline R-squared & 0.00009 & 0.00011 \\
Obs. & $3,685,235$ & $3,685,235$ \\
Workers & 222,174 & 222,174 \\
Mean of dep. var. & 13.34 & 13.34 \\
Worker FE & Yes & Yes \\
Firm FE & Yes & Yes \\
Month FE & Yes & Yes \\
Municipality-Year FE & Yes & Yes \\
\hline \hline
\end{tabular}

Notes: Table shows estimates from Equation 1.2.3. We use our preferred specification, which includes worker, firm, month and municipality-year fixed effects. Regressions include precipitation variables as controls (same functional form as in Equation 3.2.1) and standard errors are clustered by economic region. Data sources: labor market data from RAIS 2015-2016 and weather data from Xavier, King e Scanlon (2017).

\subsection{Nominal wages and employment contracts}

One plausible explanation for the effects we see on hourly wages is that workers and firms engage in a (implicit) risk-sharing labor arrangement whereby workers accept temporary reductions in nominal wages to avoid layoffs when faced with short-term labor demand shocks Franklin e Labonne (2019). ${ }^{1.5 .1}$ Therefore, motivated by a literature that studies labor market responses to environmental shocks Dell, Jones e Olken (2014), Franklin e Labonne (2019), Kaur (2019), we ask if short-term temperature shocks impact nominal wages in Brazil's formal urban

\footnotetext{
1.5.1 The premise is that extreme temperatures have an adverse impact on workers' productivity. Recent studies using data from the manufacturing sector have established the link between temperatures and worker output in China Cai, Lu e Wang (2018) and India (Bangalore) Adhvaryu, Kala e Nyshadham (2020).
} 
labor markets.

We estimate the parameters from Equation (3.2.1) for nominal wages and show the results in Figure 1.5.1. The observed pattern in the temperaturewage relationship resembles the one in Figure 1.4.1 where we used real wages. The magnitudes of the effects, however, are about half the size. Results using temperature bins and HDD yield the same conclusions: while the estimates of the effects of extreme hot temperatures on nominal wages are negative and significant, they are also smaller in magnitude than the ones we see for real wages. (See Appendix Figure 1.8.6 and Appendix Table 1.8.4.)

Figure 1.5.1 - Marginal effects of $1^{\circ} \mathrm{C}$ shock on log of nominal hourly wages
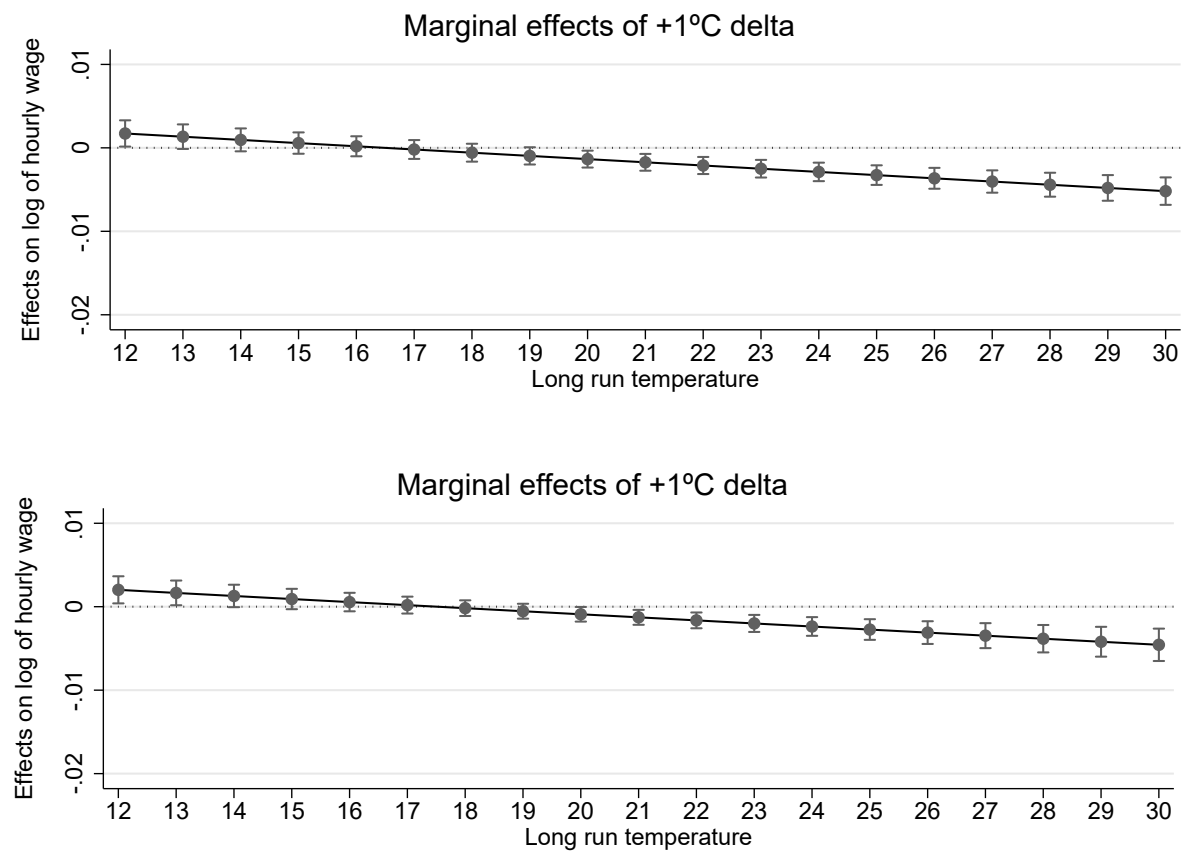

Notes: Figures show marginal effects of $1^{\circ} \mathrm{C}$ temperature shock on the log of nominal hourly wages for different levels of climate temperature $(\bar{T})$. Top figure refers to column 3 of Appendix Table 1.8.5, which uses municipality, year and month fixed effects. The bottom figure refers to column 7 of Appendix Table 1.8.5, which adds worker and firm fixed effects and swaps municipality and year by municipality-year fixed effects. Data sources: labor market data from RAIS 2015-2016 and weather data from Xavier, King e Scanlon (2017).

Next, we ask if these shocks had an effect on employment outcomes. The 
RAIS dataset allows us to look at contractual hours, days on leave, the incidence of permanent employment contracts and payment schemes (monthly payments vs other forms). ${ }^{1.5 .2}$ We present the results in Table 1.5.1. We find no significant effects on contractual hours and other employment outcomes. ${ }^{1.5 .3}$

Taken together, these results suggest that nominal wages indeed adjust in response to transitory temperature shocks in Brazil's formal labor markets, and that changes in wages may be the main adjustment mechanism available to deal with such shocks since we find no effect on other employment outcomes. In the next section, we turn our investigation to the composition channel.

\subsection{Composition effects}

We turn to another relevant mechanism leading to wage effects from temperature shocks: jobs and labor force composition. Most analyses based on aggregatelevel data do not deal with the possibility that weather shocks alter the types of jobs and workers that are observed in a given locality at a certain period of time, especially studies relying on annual data where economic agents have more time to adapt to changes. If individuals react to environmental shocks by migrating in and out of localities, or switching jobs and sectors, an empirical relationship between (nominal and real) wages and temperature may not be attributed to causal direct productivity impacts only, but also to changes in workforce skill composition, both observed and unobserved, or sectoral mix.

Because we have a panel of workers and observe them when they change firms, sectors, or municipality, we examine further if temperature shocks lead to such changes. ${ }^{16.1}$ We present the results in Table 1.6.1. We use the temperature

\footnotetext{
${ }^{1.5 .2}$ Other forms of payment scheme take on value zero, and they comprise the categories weekly, hourly, bi-weekly, daily, and by task ("tarefa"). Note that $93 \%$ of the sample work under a monthly payment scheme, indicating that this is the major payment scheme prevailing in Brazil's formal non-agriculture labor markets. See Appendix A.2. for more information on these outcomes.

${ }^{1.5 .3}$ While we do not have data on layoffs from RAIS, we use an indicator for whether the worker left our sample as a proxy for leaving the formal labor market. We also find no effect on this outcome.

${ }^{1.6 .1}$ See Appendix A.2. for more information on these outcomes.
} 
Table 1.5.1 - Temperature shocks and employment outcomes

\begin{tabular}{lcccc}
\hline \hline & Log hours & Days on leave & Permanent job & Monthly payment \\
\hline$\Delta$ Temp & 0.00005 & -0.01560 & -0.00006 & 0.00008 \\
& $(0.00006)$ & $(0.01110)$ & $(0.00008)$ & $(0.00007)$ \\
$(\Delta$ Temp $) \cdot \bar{T}$ & -0.00000 & 0.00090 & 0.00000 & -0.00000 \\
& $(0.00000)$ & $(0.00057)$ & $(0.00000)$ & $(0.00000)$ \\
\hline R-squared & -0.00000 & 0.00000 & -0.00000 & -0.00000 \\
Obs. & $3,685,235$ & $3,685,235$ & $3,685,235$ & $3,685,235$ \\
Workers & 222,174 & 222,174 & 222,174 & 222,174 \\
Mean of dep. var. & 3.75 & 0.30 & 0.98 & 0.92 \\
Worker FE & Yes & Yes & Yes & Yes \\
Firm FE & Yes & Yes & Yes & Yes \\
Month FE & Yes & Yes & Yes & Yes \\
Municipality-Year FE & Yes & Yes & Yes & Yes \\
\hline \hline
\end{tabular}

Notes: Log hours in the log of contractual working hours, Days on leave is the number of days worker is on leave of absence, Permanent job is an indicator for whether the worker is in a permanent employment contract (zero if temporary), Monthly payment is an indicator for whether payment is received on monthly basis (zero if weekly, daily, biweekly, hourly or piece rate). All regressions include precipitation variables as controls and standard errors are clustered by economic region. Data sources: labor market data from RAIS 2015-2016 and weather data from Xavier, King e Scanlon (2017).

shock from the previous month to account for the fact that these transitions are less likely to be made based on current weather changes. We find evidence suggesting movement across sectors and firms, in patterns consistent with what we find for wages.

We do not believe, however, that these changes explain the wage effects we find for two reasons. First, the percent of workers that changed sector or firms within the period we study is very small ( $4 \%$ and $9 \%$ ). Second, and more importantly, the estimates with and without worker and firm fixed effects we present in Table 1.4.1 differ very little.

To make this point clearer, in Appendix Table 1.8.6, column (2), we present further results obtained after removing from the sample workers that have changed cities, firm, or sectors at any time during the period we study. We show that the results are virtually the same as our main estimates, which we present in column 
(1), suggesting that these transitions are not driving our results. Finally, to check if movements of workers in and out of formal labor markets explain our findings, we compare our main estimates with those obtained for a balanced sample consisting of workers that never left our sample in Appendix Table 1.8.6, column (3). Again, the results change very little. We take this as suggestive evidence that these transitions have little role in the estimated temperature-wage relationship.

Table 1.6.1 - Temperature shocks and labor market movements

\begin{tabular}{lcccc}
\hline \hline & Municipality & Sector & Firm & Out Lab. Market \\
\hline$\Delta$ Temp & -0.00027 & $-0.00056^{* * *}$ & $-0.00094^{* *}$ & -0.00155 \\
& $(0.00027)$ & $(0.00021)$ & $(0.00040)$ & $(0.00406)$ \\
$(\Delta$ Temp $) \bar{T}$ & 0.00001 & $0.00003^{* * *}$ & $0.00006^{* * *}$ & -0.00018 \\
& $(0.00001)$ & $(0.00001)$ & $(0.00002)$ & $(0.00018)$ \\
\hline R-squared & 0.00001 & 0.00001 & 0.00003 & 0.00021 \\
Obs. & $3,511,917$ & $3,511,917$ & $3,511,917$ & $5,037,827$ \\
Workers & 218,229 & 218,229 & 218,229 & 227,225 \\
Mean of dep. var. & 0.001 & 0.002 & 0.005 & 0.301 \\
Worker FE & Yes & Yes & Yes & Yes \\
Firm FE & Yes & Yes & Yes & Yes \\
Month FE & Yes & Yes & Yes & Yes \\
Municipality-Year FE & Yes & Yes & Yes & Yes \\
\hline \hline
\end{tabular}

Notes: Municipality is an indicator for whether the worker changes municipalities; Sector is an indicator for changing sector of employment, Firm is an indicator for changing firms; Out Lab. Market is an indicator for whether the worker has left the sample (the outcome variable takes on value 1 if worker is in the sample, and 0 if worker was in sample in previous months but no longer is in that month). All regressions include precipitation variables as controls and standard errors are clustered by economic region. Data sources: labor market data from RAIS 2015-2016 and weather data from Xavier, King e Scanlon (2017).

\subsection{Heterogeneous effects}

Finally, we ask the following question: Could the wage effects we estimate be explained by the relationship between temperature and labor productivity? A large and well-established body of research conclude that extreme cold and hot temperatures are detrimental to worker productivity, with tasks such as attention, 
vigilance, and mental arithmetic being adversely affected Ramsey (1995), Pilcher, Nadler e Busch (2002), Seppänen, Fisk e Lei (2006). Recently, studies employing short-term weather and actual output production data from manufacturing sector in developing countries find direct evidence of the negative consequences of hot temperatures for worker productivity Cai, Lu e Wang (2018), Adhvaryu, Kala e Nyshadham (2020). Thus, if workers are less productive when exposed to harmful heat levels, real wages would fall.

Our main challenge is that, unlike the aforementioned studies, we do not have a direct measure of worker output. While we cannot provide direct evidence for this channel, we attempt to do so indirectly. The idea is to classify workers according to their likely exposure to a non-climate-controlled working environment based on information about their occupation Zivin e Neidell (2014), Behrer e Park (2017), Zhang et al. (2018). But instead of choosing the occupations arbitrarily, we opt for using information on the distribution of wages and education across occupations. The occupations in the bottom 25th percentile of wage and education are classified as "exposed" to weather and climate, whereas those in the top 25th percentile of wage and education are classified as "less exposed". 1.7.1

We present the results in Figure 1.7.1. ${ }^{1.7 .2}$ We find that the wages of workers in high skilled occupations (less exposed) do not respond to temperature increases, whereas the wage of workers in low skilled occupations (exposed) do. The difference in the estimated effects between the two groups is statistically different starting at a $22^{\circ} \mathrm{C}$ climate temperature.

We take these finding as suggestive (indirect) evidence of the labor productivity mechanism, assuming that workers in the low skilled occupations are more likely to perform their jobs outdoors or in non-climate-controlled indoor environments. It is plausible, however, that the explanation for these results is dif-

\footnotetext{
${ }^{1.7 .1}$ We first take the average years of schooling and hourly wages within each occupation. Then we calculate the 25 th and 75 th percentile of the distribution of years of schooling and hourly wages to classify each occupation. We disregard the ones between the 25th and 75th percentiles. See Appendix Table 1.8.7 for a list of occupations in each of the categories. We use around 600 occupations for our empirical exercise. They are summarized in about 100 broader categories in the table.

1.7.2 Appendix Table 1.8.8 shows the estimates.
} 
ferences in labor market mobility (leading to stronger composition effects amongst low-skilled occupations) or in adjustment to employment contracts among the two groups. The evidence, however, does not point in that direction. (See Appendix Tables 1.8.9 and 1.8.10.)

Figure 1.7.1 - Marginal effects of $1^{\circ} \mathrm{C}$ shock on log of real hourly wage - Exposed vs less exposed occupations

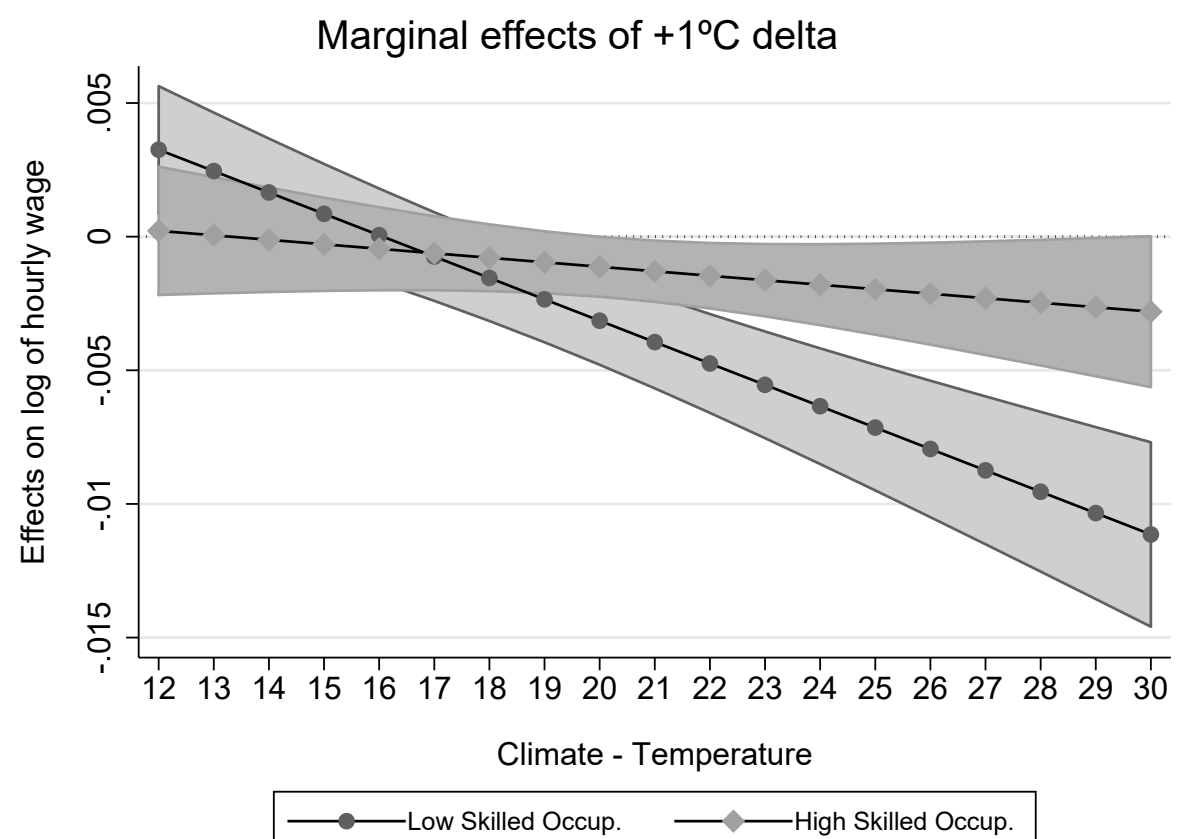

Notes: Figure shows marginal effects of $1^{\circ} \mathrm{C}$ temperature shock on the log of real hourly wages for different levels of climate temperature $(\bar{T})$. Effects are separated for Low Skilled Occupations and High Skilled Occupations. Low Skilled Occupations are defined as the bottom 25th percentile of the occupation wage and education distributions, High Skilled Occupations the top 25th. Regressions also include precipitation variables as controls and standard errors are clustered by economic region. A version of this exercise using nominal wages is presented in Appendix Figure 1.8.7. Data sources: labor market data from RAIS 2015-2016 and weather data from Xavier, King e Scanlon (2017). 


\subsection{Final remarks}

This paper employs individual-level panel data and exploits monthly variations in weather to study whether and how wages respond to short-term temperature shocks that potentially affect worker's productivity. Our main conclusion is that there are positive effects in colder climates, but negative effects in warmer climates. This inverse U-shaped result echoes the findings from some studies using cross-country comparisons, and firm-level output and worker's actual productivity data.

We are able to draw some relevant insights from our analysis. Because Brazil's warmer North and Northeast regions are the poorest, weather vulnerability might deepen the existing south-north inequality. Furthermore, the negative effect on wages in warmer climates outweighs the positive impact in colder climates, suggesting that average income losses may be larger as future climate becomes warmer if no adaptation occurs. Finally, we find effects for exposed, low-skilled, occupations but not for less-exposed ones. Thus, workplace susceptibility to temperature shocks may also create further disparities in incomes.

It is worth noting that because of data limitations, our analysis is restricted to formal-sector workers, leaving out around $40 \%$ of Brazil's labor force that is employed in the informal sector. We believe, however, that this omission leads us to understate the adverse wage effects of elevated temperature, as informal workers are likely to be more vulnerable to weather shocks. 


\section{Appendix A}

\section{A.1. Sampling procedure}

Our source of monthly wages data is the Annual Social Information Report (RAIS). RAIS is an administrative database collected by the Ministry of Labor of Brazil. It covers $99 \%$ of the formal labor force in the country and, therefore, is the most reliable source of labor market data. The monthly wage data is available from 2015 on and firms must inform data from all employees. We use data starting in January of 2015 and ending in December of 2016.

For computational reasons, we draw a random sample of $1 \%$ of the universe of workers and match them with weather information using the municipalities where the job is performed. We also restrict our sample to workers aged 25 to 55 to exclude interns and part-time students and workers near retirement. Workers in the public administration and military occupations are also dropped because most of them have tenure and wages adjustments are much lower for these job categories. We end up with an unbalanced panel of 329,784 workers. Due to the fixed effects we include in our model and to the matching with weather variables, many observations are pruned during estimations. Our final estimation sample has $3,685,235$ worker-month observations covering 222,174 total workers.

\section{A.2. Additional labor market information}

We use four variables to explore the weather effects on other employment outcomes. They are: days on leave, contractual hours, permanent job, and payment scheme. We explain below how we construct each of these variables:

- Log hours: For each worker we have data on the number of hours hired per week, which are defined by the contract between the employer and the employee. We use this variables in logarithm in our empirical exercise; 
- Days on leave: For workers who have been absent from work, RAIS provides data on the start and end of the leave and the reason why the worker was absent. The main reasons for the leaves include accidents (related or not to the work), diseases (related or not to the work), licenses (paid or not) and military service. Accidents, diseases and unpaid licenses comprehend more than $80 \%$ of the reasons. Using the data on the start and end of the leave, we calculate, by month, how many days of work the individual missed. In case the worker have not missed a single day of work in that month, this variable assumes value zero;

- Permanent job: RAIS also collects data on the type of contract signed between employers and employee: permanent or temporary. We create a dummy that assumes value one when the contract is permanent, which corresponds to $98 \%$ of the sample; and

- Monthly payment: RAIS also collects data on the payment scheme (frequency) under which the worker was hired. The payment schemes are monthly, weekly, hourly, bi-weekly, daily, and by task ("tarefa"). We create a dummy assuming value one when the payment scheme is monthly, what represents around $93 \%$ of the workers' payment scheme.

We also explore other four binary variables to analyze labor market mobility, in terms of municipality, sector, employer/firm or permanence in the labor market. As we observe worker's data by month and all firms report the data from their employees, we are able to identify when they change firms, sectors, municipality and also when they leave the sample (to unemployment or to informal jobs).

- Municipality: Binary variable that assumes value one when the worker changed the municipality of its workplace in relation to the previous month and zero otherwise. Around 3\% of the workers changed municipality between 2015 and 2016;

- Sector: Binary variable that assumes value one when the worker changed the sector where he/she is employed in relation to the previous month and zero otherwise. Around 4\% of the workers changed sector between 2015 and 2016; 
- Firm: Binary variable that assumes value one when the worker changed employer in relation to the previous month and zero otherwise. Around 9\% of the workers changed employer between 2015 and 2016; and

- Out of Labor Market: Binary variable that assumes value one when the worker is out of the labor market (i.e. when we do not observe wage data) and zero otherwise. When the individual leaves the labor market, we are not able to tell if it was fired, or if he quit. We are also not able to discriminate between unemployment and transition to informal jobs. We observe wages by worker in 16.6 (out of 24) months on average in the estimating sample.

The main statistics of the variables described above are in Table 1.3.1 and in the result tables that employ them. We calculate the statistics of Table 1.3.1 at the worker level and, for this reason, they are slightly different from those presented in the result tables, which use the worker-month dimension. 


\section{Appendix figures}

Figure 1.8.1 - Weather temperature distribution (in ${ }^{\circ} \mathrm{C}$ ) - Full vs Estimation Sample

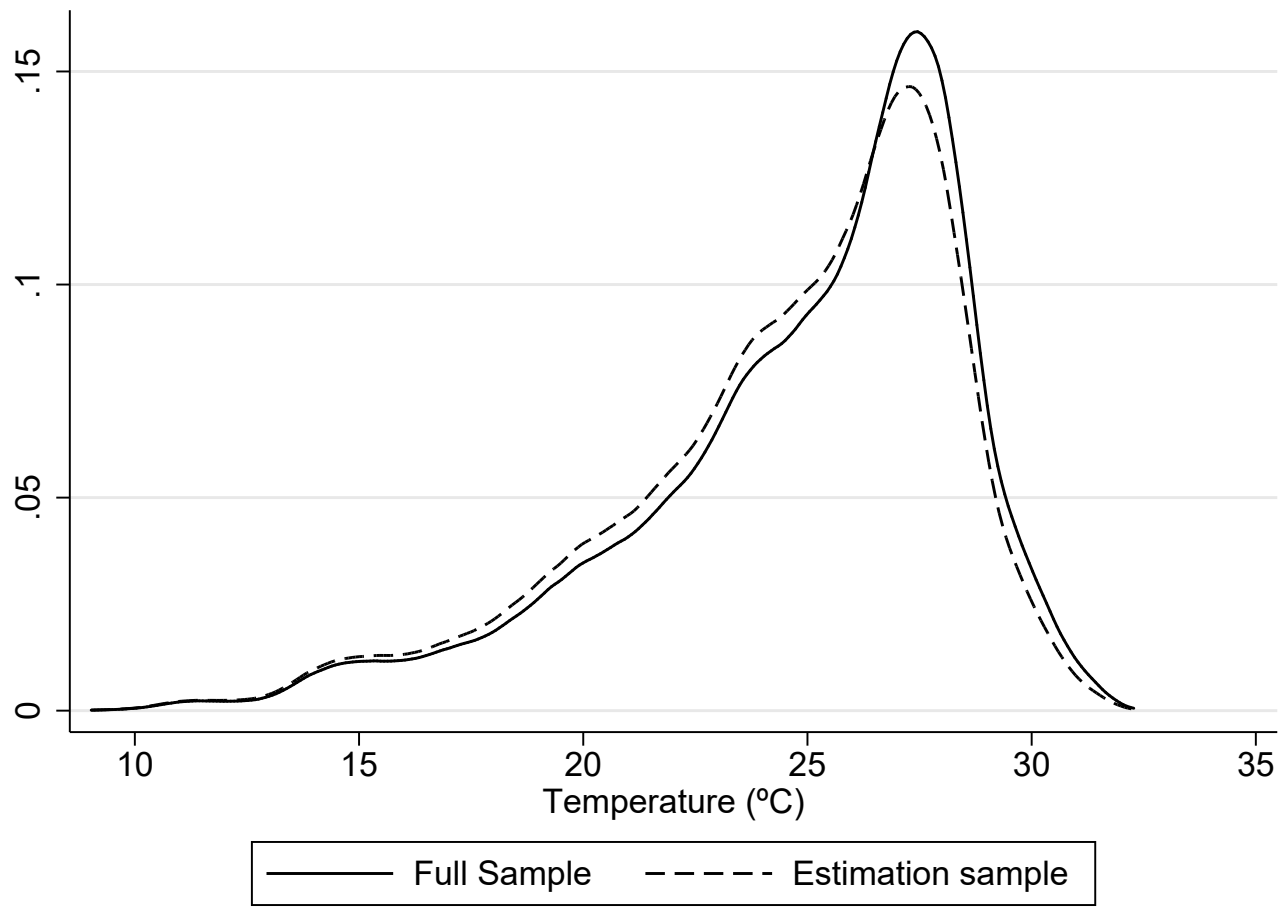

Notes: Figure compares the distribution of weather temperature in the full sample and in our estimation sample. The full sample has 3,226 municipalities while the estimation sample has 2,829. Data source: Xavier, King e Scanlon (2017), 2015-2016. 
Figure 1.8.2 - Climate temperature distribution $\left(\right.$ in $\left.{ }^{\circ} \mathrm{C}\right)$ - Full vs Estimation Sample

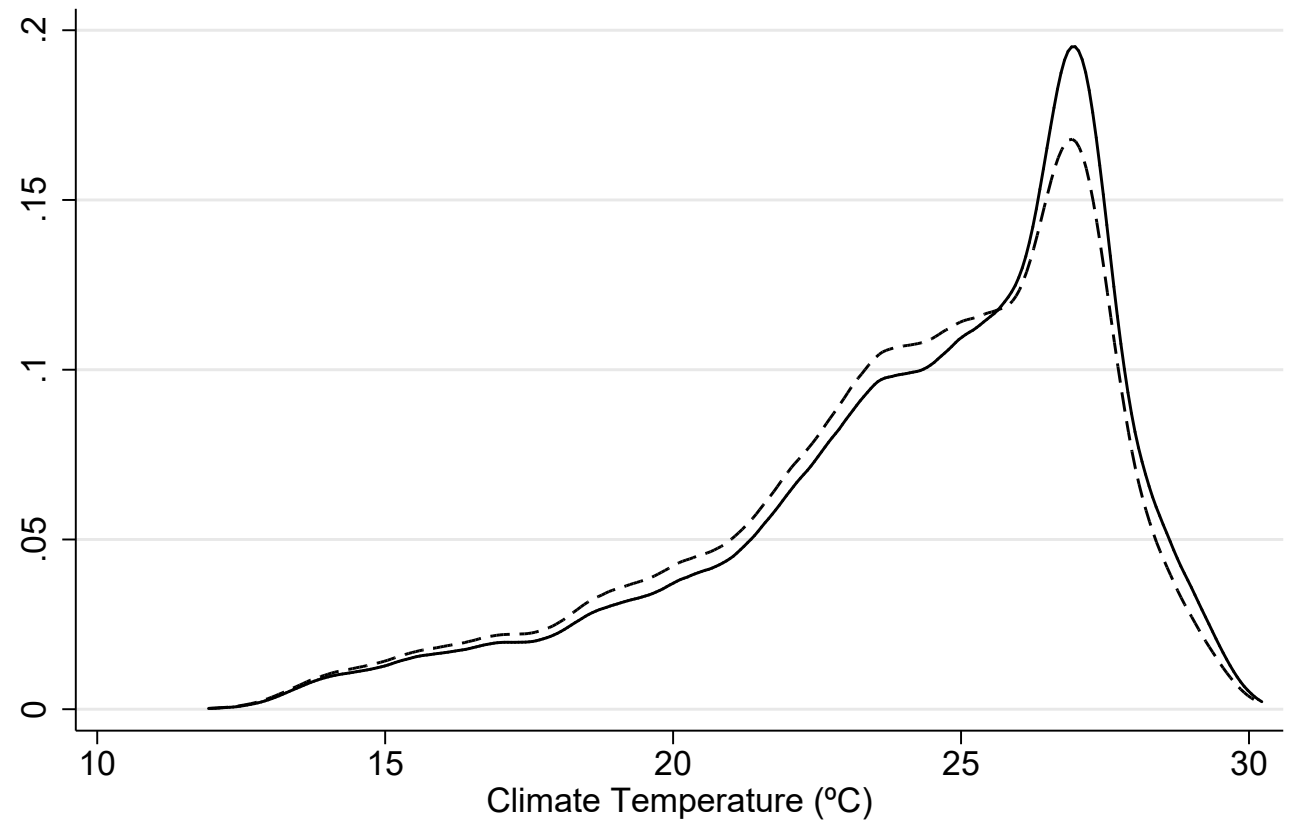

Full Sample - - - - Estimation sample

Notes: Figure compares the distribution of climate temperature in the full sample and in our estimation sample. The full sample has 3,226 municipalities while the estimation sample has 2,829. Data source: Xavier, King e Scanlon (2017), 1980-2016. 
Figure 1.8.3 - Weather and climate temperature distribution $\left(\right.$ in $\left.{ }^{\circ} \mathrm{C}\right)$

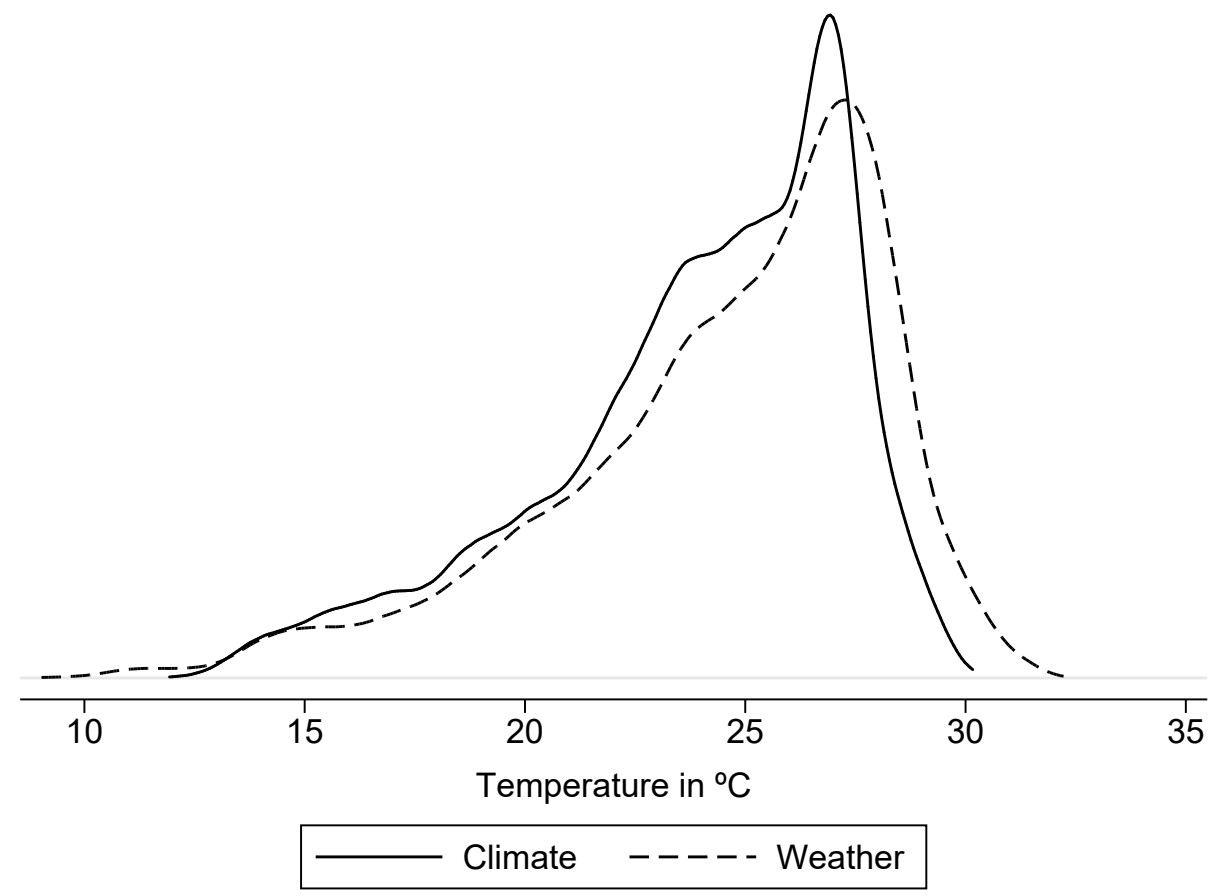

Notes: Figure shows the distribution of weather and climate temperature variables in our estimation sample. Data source: Xavier, King e Scanlon (2017), 1980-2016. 
Figure 1.8.4 - Distributions of bin variables
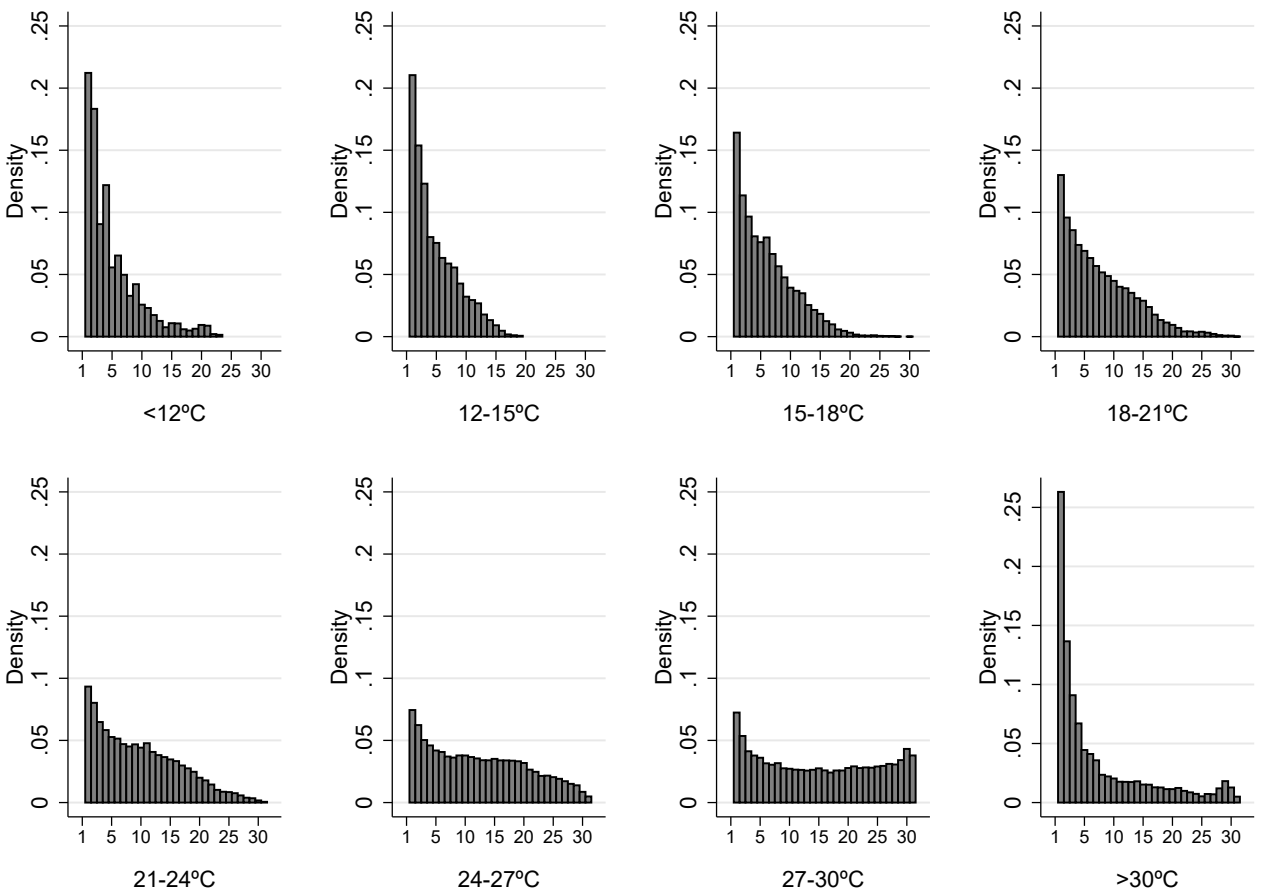

Notes: Figure shows the distribution of each bin variable in our estimating sample. They are calculated monthly for the years of 2015 and 2016. Distributions are presented for positive values only. Data source: Xavier, King e Scanlon (2017), 2015-2016. 
Figure 1.8.5 - Harmful Degree Days (HDD) distribution $\left(\right.$ in ${ }^{\circ} \mathrm{C}$ )

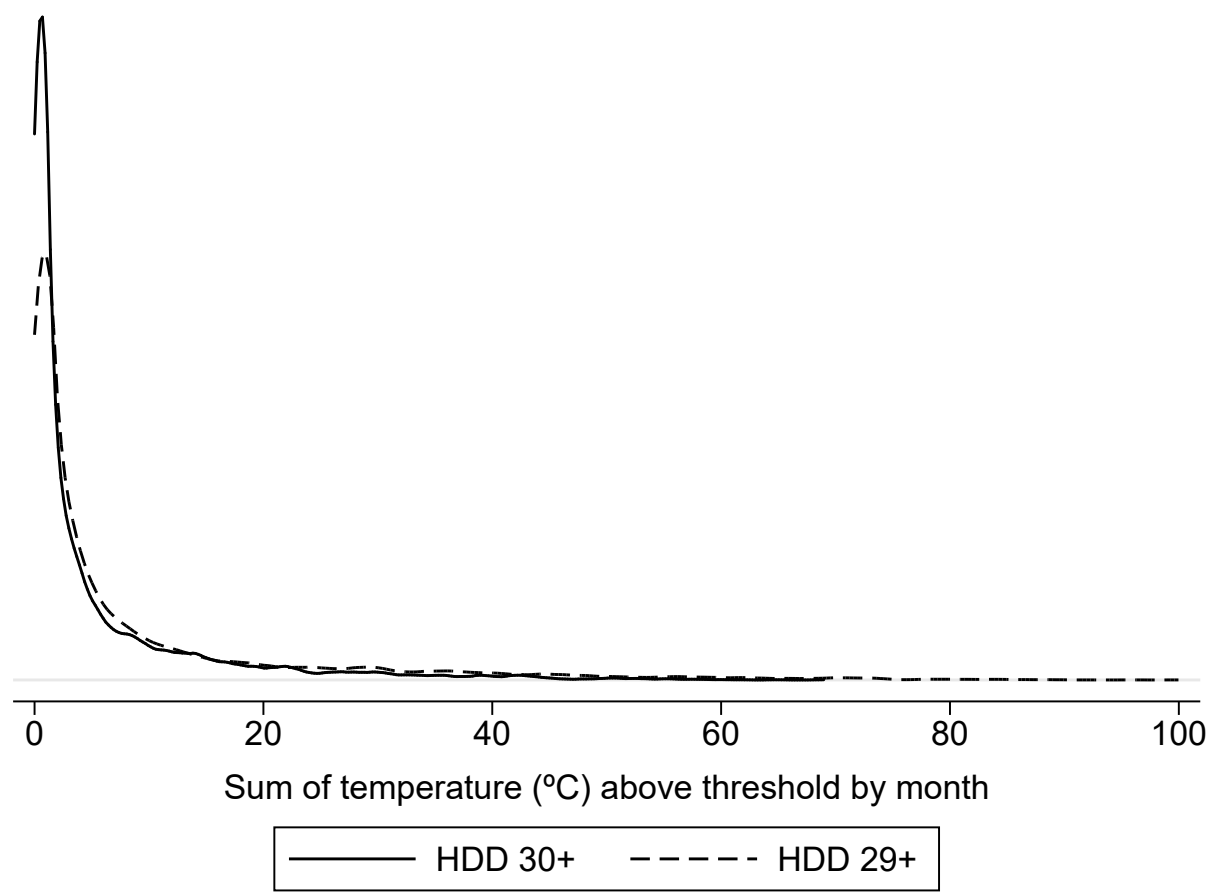

Notes: Figure shows the distribution of Harmful Degree Days (HDD) calculated for our estimating sample in two versions: above $29^{\circ} \mathrm{C}$ and above $30^{\circ} \mathrm{C}$. Distributions are presented for positive values only. Data source: Xavier, King e Scanlon (2017), 2015-2016. 
Figure 1.8.6 - Impacts of temperature on nominal wages, alternative specification Temperature Bins

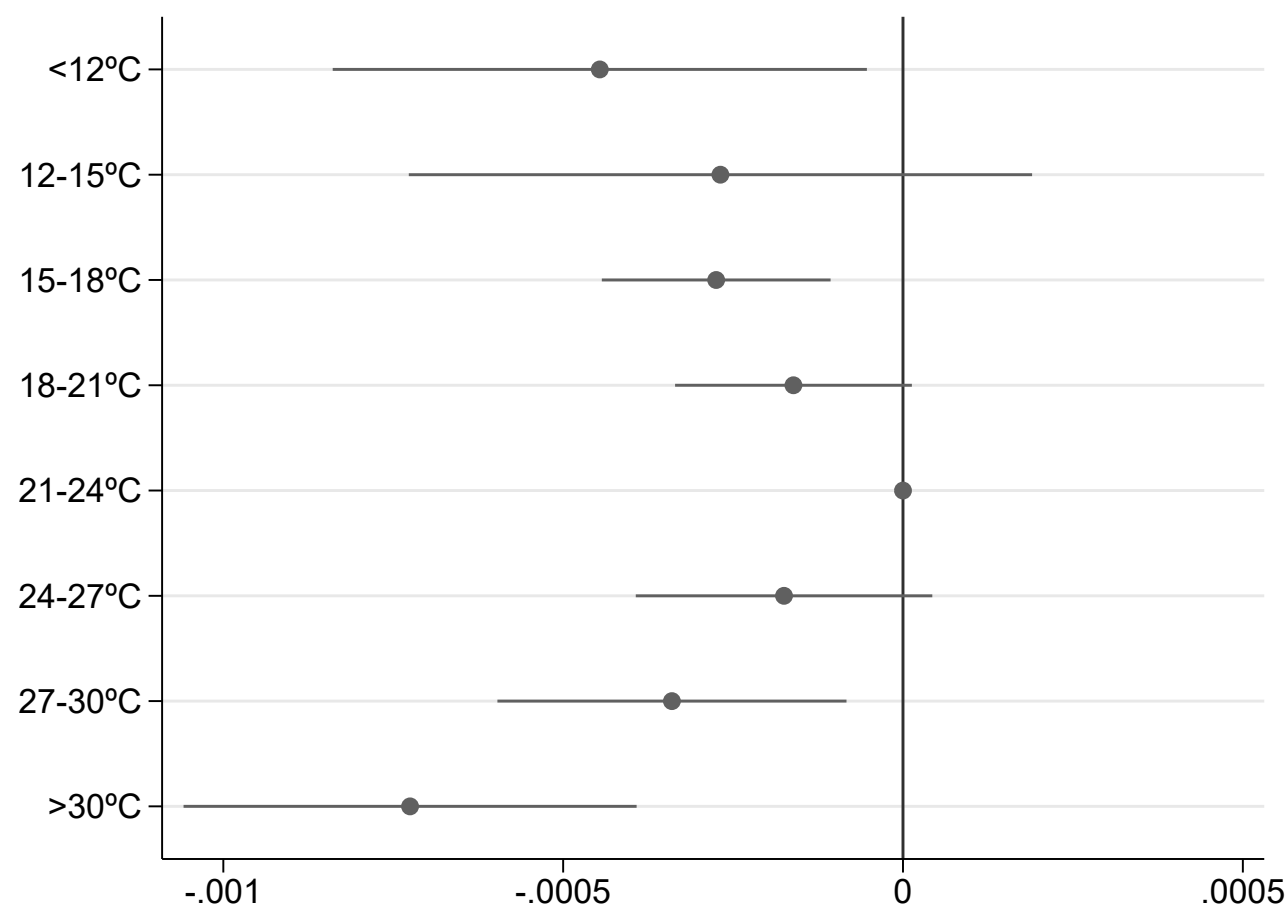

Notes: Figure shows the regression of the log of nominal hourly wages on temperature bins. They range from below $12^{\circ} \mathrm{C}$ to above $30^{\circ} \mathrm{C}$ in sets of $3^{\circ} \mathrm{C}$. The $21-24^{\circ} \mathrm{C}$ bin is set to zero so the others are interpreted relative to a day in the $21-24^{\circ} \mathrm{C}$ bin. We use our preferred specification, which includes worker, firm, month and municipality-year fixed effects. For the regression we use a monthly unbalanced sample of the Brazilian formal labor market for the years of 2015-2016. Wages are used in nominal terms. Regressions also includes nine precipitation bins as controls (see Equation 1.2.2) and standard errors are clustered by economic region. This is the same specification as column 7 - Appendix Table 1.8.5, but changing weather deviations for weather bins. A version of this exercise using real wages, instead of nominal wages, was presented in the Figure 1.4.2. Appendix Table 1.8.11 shows the estimation results. Data sources: labor market data from RAIS 2015-2016 and weather data from Xavier, King e Scanlon (2017). 
Figure 1.8.7 - Marginal effects of $1{ }^{\circ} \mathrm{C}$ shock on log of nominal hourly wage Exposed vs less exposed occupations

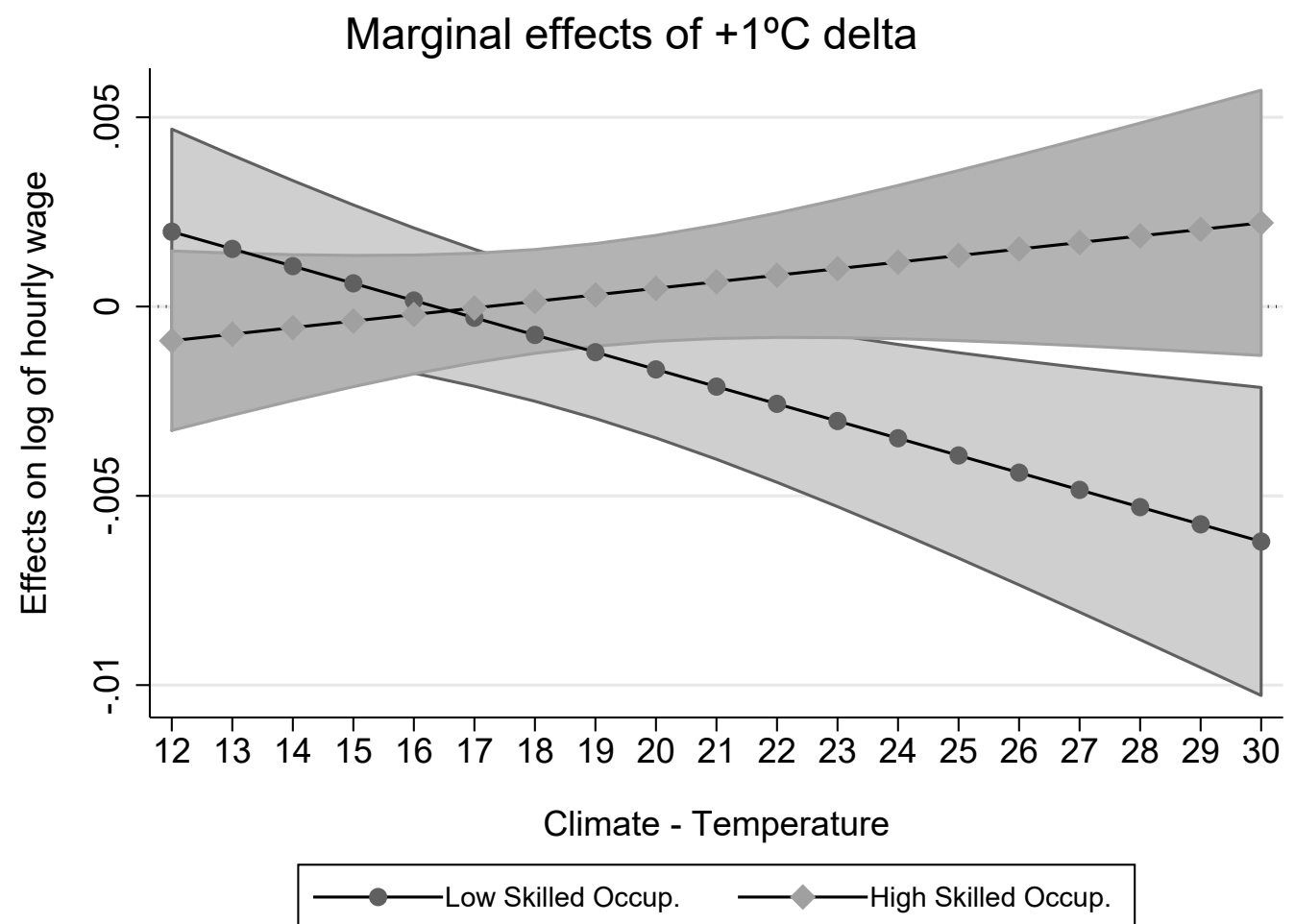

Notes: Figure shows marginal effects of $1^{\circ} \mathrm{C}$ temperature shock on the log of nominal hourly wages for different levels of climate temperature $(\bar{T})$. Effects are separated for Low Skilled Occupations and High Skilled Occupations. Low Skilled Occupations are defined as the bottom 25th percentile of the occupation wage and education distributions, High Skilled Occupations the top 25th. Regressions also include precipitation variables as controls and standard errors are clustered by economic region. A version of this exercise using real wages is presented in Figure 1.7.1. Data sources: labor market data from RAIS 2015-2016 and weather data from Xavier, King e Scanlon (2017). 


\section{Appendix tables}

Table 1.8.1 - Distribution of workers according to the number of times wages changed in consecutive months

\begin{tabular}{|c|c|c|c|c|c|c|}
\hline & \multicolumn{3}{|c|}{ Nominal Wages } & \multicolumn{3}{|c|}{ Real Wages } \\
\hline & Obs. & Mean & Std. Dev. & Obs. & Mean & Std. Dev. \\
\hline 0 & 4,967 & $1,461.8$ & $1,753.2$ & 254 & $2,235.7$ & $4,781.6$ \\
\hline 1 & 14,508 & $1,582.3$ & $1,900.0$ & 7,441 & $1,489.8$ & $1,593.5$ \\
\hline 2 & 13,422 & $1,685.9$ & $2,269.4$ & 7,451 & $1,576.7$ & $2,020.3$ \\
\hline 3 & 12,944 & $1,708.1$ & $1,997.4$ & 7,010 & $1,595.1$ & $1,771.4$ \\
\hline 4 & 12,067 & $1,817.6$ & $2,173.9$ & 6,290 & $1,630.6$ & $2,068.3$ \\
\hline 5 & 12,356 & $1,872.8$ & $2,243.9$ & 6,091 & $1,584.2$ & $1,459.5$ \\
\hline 6 & 11,741 & $1,951.3$ & $2,142.4$ & 6,071 & $1,666.9$ & $1,839.5$ \\
\hline 7 & 11,158 & $2,065.5$ & $2,342.5$ & 5,754 & $1,631.4$ & $1,748.1$ \\
\hline 8 & 10,162 & $2,162.1$ & $2,607.7$ & 5,442 & $1,603.3$ & $1,463.0$ \\
\hline 9 & 9,410 & $2,348.0$ & $2,899.5$ & 5,677 & $1,706.0$ & $1,672.4$ \\
\hline 10 & 8,716 & $2,367.0$ & $2,738.9$ & 5,356 & $1,691.1$ & $1,672.1$ \\
\hline 11 & 10,542 & $2,467.2$ & $2,903.9$ & 14,550 & $2,134.8$ & $2,738.9$ \\
\hline 12 & 6,832 & $2,443.8$ & $2,796.3$ & 6,139 & $1,740.3$ & $1,635.8$ \\
\hline 13 & 6,246 & $2,457.8$ & $2,802.5$ & 6,084 & $1,702.7$ & $1,605.2$ \\
\hline 14 & 5,827 & $2,406.2$ & $2,648.8$ & 6,195 & $1,714.5$ & $1,653.6$ \\
\hline 15 & 5,420 & $2,397.6$ & $2,632.5$ & 6,152 & $1,723.8$ & $1,643.5$ \\
\hline 16 & 5,198 & $2,481.5$ & $2,888.9$ & 6,349 & $1,777.4$ & $2,001.8$ \\
\hline 17 & 5,197 & $2,489.4$ & $2,752.6$ & 6,260 & $1,796.8$ & $2,010.3$ \\
\hline 18 & 4,752 & $2,465.3$ & $2,607.1$ & 5,548 & $1,809.6$ & $1,852.2$ \\
\hline 19 & 4,733 & $2,482.2$ & $2,543.3$ & 5,472 & $1,862.5$ & $1,963.9$ \\
\hline 20 & 5,077 & $2,607.6$ & $2,687.0$ & 5,327 & $1,859.2$ & $1,773.6$ \\
\hline 21 & 5,804 & $2,580.3$ & $2,509.9$ & 6,643 & $1,895.8$ & $2,007.9$ \\
\hline 22 & 6,519 & $2,676.4$ & $2,636.4$ & 3,722 & $1,915.1$ & $1,798.7$ \\
\hline 23 & 28,576 & $2,856.2$ & $2,522.6$ & 80,896 & $2,541.4$ & $2,772.4$ \\
\hline Total & 222,174 & $2,216.0$ & $2,501.7$ & 222,174 & $2,037.9$ & $2,301.6$ \\
\hline
\end{tabular}

Notes: Table displays the distribution of workers in the estimating sample across the number of times wages changed in consecutive months from January of 2015 to December of 2016. Under Mean and Std. Dev. we present the mean and standard deviation of wages by each subgroup of workers according to the number of changes. Data source: RAIS 2015-2016. 
Table 1.8.2 - Summary statistics of monthly temperature variables

\begin{tabular}{lccccccc}
\hline \hline & Mean & SD & Min & p25 & Median & p75 & Max \\
\hline Temperature $\left({ }^{\circ} \mathrm{C}\right)$ & 24.50 & 3.78 & 9.03 & 22.42 & 25.35 & 27.33 & 32.22 \\
Climate Temperature $\left({ }^{\circ} \mathrm{C}\right)$ & 23.87 & 3.49 & 11.93 & 21.95 & 24.59 & 26.66 & 30.16 \\
Delta Temperature $\left({ }^{\circ} \mathrm{C}\right)$ & 0.64 & 0.93 & -4.34 & 0.09 & 0.64 & 1.19 & 5.07 \\
HDD 29+ & 2.26 & 8.05 & 0.00 & 0.00 & 0.00 & 0.12 & 99.97 \\
HDD 30+ & 0.66 & 3.62 & 0.00 & 0.00 & 0.00 & 0.00 & 68.97 \\
Bin 1: $<12^{\circ} \mathrm{C}$ & 0.39 & 1.86 & 0.00 & 0.00 & 0.00 & 0.00 & 23.00 \\
Bin 2: $12-15^{\circ} \mathrm{C}$ & 0.70 & 2.22 & 0.00 & 0.00 & 0.00 & 0.00 & 19.00 \\
Bin 3: $15-18^{\circ} \mathrm{C}$ & 1.46 & 3.44 & 0.00 & 0.00 & 0.00 & 0.00 & 30.00 \\
Bin 4: $18-21^{\circ} \mathrm{C}$ & 2.96 & 5.18 & 0.00 & 0.00 & 0.00 & 4.00 & 31.00 \\
Bin 5: $21-24^{\circ} \mathrm{C}$ & 5.59 & 7.11 & 0.00 & 0.00 & 2.00 & 10.00 & 31.00 \\
Bin 6: $24-27^{\circ} \mathrm{C}$ & 9.53 & 8.92 & 0.00 & 1.00 & 8.00 & 17.00 & 31.00 \\
Bin 7: $27-30^{\circ} \mathrm{C}$ & 8.89 & 10.56 & 0.00 & 0.00 & 3.00 & 18.00 & 31.00 \\
Bin 8: $>30^{\circ} \mathrm{C}$ & 0.93 & 3.78 & 0.00 & 0.00 & 0.00 & 0.00 & 31.00 \\
\hline \hline
\end{tabular}

Notes: Table presents summary statistics of the temperature variables used in our empirical exercises: temperature and climate temperature, that generate delta temperature (all in ${ }^{\circ} \mathrm{C}$ ), used in our main specification - Equation (3.2.1); harmful degree days calculated above $29^{\circ} \mathrm{C}$ (HDD 29+) and above $30^{\circ} \mathrm{C}$ (HDD 30+) - Equation (1.2.2); and eight temperature bins ranging from $<12^{\circ} \mathrm{C}$ to $>30^{\circ} \mathrm{C}$ in sets of $3^{\circ} \mathrm{C}-$ Equation (1.2.3). Statistics are calculated monthly for the municipalities in our estimating sample. Data source: Xavier, King e Scanlon (2017), 1980-2016. 
Table 1.8.3 - Alternative specification - Temperature Bins, Results of Figure 1.4.2

\begin{tabular}{cc}
\hline \hline & Month FE \\
\hline$<12^{\circ} \mathrm{C}$ & $\begin{array}{c}-0.0003 \\
(0.0002)\end{array}$ \\
& $\begin{array}{c}-0.0002 \\
12-15^{\circ} \mathrm{C}\end{array}$ \\
& $(0.0002)$ \\
$15-18^{\circ} \mathrm{C}$ & $-0.0002^{* *}$ \\
& $(0.0001)$ \\
$18-21^{\circ} \mathrm{C}$ & -0.0000 \\
& $(0.0001)$ \\
& \\
$21-24^{\circ} \mathrm{C}$ & 0.0000 \\
& $()$. \\
$24-27^{\circ} \mathrm{C}$ & $-0.0002^{*}$ \\
& $(0.0001)$ \\
$27-30^{\circ} \mathrm{C}$ & $-0.0005^{* * *}$ \\
& $(0.0001)$ \\
$>30^{\circ} \mathrm{C}$ & $-0.0010^{* * *}$ \\
& $(0.0001)$ \\
\hline \hline
\end{tabular}

Notes: Table presents the results of Figure 1.4.2. Data sources: labor market data from RAIS 2015-2016 and weather data from Xavier, King e Scanlon (2017). 
Table 1.8.4 - Impacts of temperature on the log of nominal hourly wages, alternative specification - Harmful Degree Days (HDD)

\begin{tabular}{lcc}
\hline \hline & $(1)$ & $(2)$ \\
& Log of hourly wage & Log of hourly wage \\
\hline HDD 30+ & $-0.00038^{* * *}$ & \\
& $(0.00012)$ & \\
HDD 29+ & & $-0.00025^{* * *}$ \\
& & $(0.00008)$ \\
\hline R-squared & 0.00002 & 0.00004 \\
Obs. & $3,685,235$ & $3,685,235$ \\
Workers & 222,174 & 222,174 \\
Mean of dep. var. & 14.57 & 14.57 \\
Worker FE & Yes & Yes \\
Firm FE & Yes & Yes \\
Month FE & Yes & Yes \\
Municipality-Year FE & Yes & Yes \\
\hline \hline
\end{tabular}

Notes: Table shows the regressions of the log of nominal hourly wages on Harmful Degree Days (HDD). HDD is calculated in two versions: above $29^{\circ} \mathrm{C}$ and above $30^{\circ} \mathrm{C}$. We use our preferred specification, which includes worker, firm, month and municipality-year fixed effects. For the regression we use a monthly unbalanced sample of the Brazilian formal labor market for the years of 2015-2016. Wages are used in nominal terms and its mean is presented in the "Mean of dep. var."line. Regressions also include precipitation variables as controls (same functional form as in Equation 3.2.1) and standard errors are clustered by economic region. This is the same specification used in column 7 - Appendix Table 1.8.5, but changing temperature deviations for HDD. A version of this exercise using real wages, instead of nominal wages, was presented in the Table 1.4.2. Data sources: labor market data from RAIS 2015-2016 and weather data from Xavier, King e Scanlon (2017). 
Table 1.8.5 - Impact of temperature shocks on nominal wages - Sample of formal workers

\begin{tabular}{lccccccc}
\hline \hline & & & & & & \\
& $(1)$ & $(2)$ & $(3)$ & $(4)$ & $(5)$ & $(6)$ & $(7)$ \\
\hline$\Delta$ Temp & $0.19278^{* * *}$ & 0.00572 & $0.00636^{* * *}$ & $0.00486^{* *}$ & $0.00541^{* *}$ & $0.00539^{* *}$ & $0.00641^{* * *}$ \\
& $(0.06235)$ & $(0.00831)$ & $(0.00237)$ & $(0.00240)$ & $(0.00226)$ & $(0.00230)$ & $(0.00181)$ \\
$(\Delta T e m p) . \bar{T}$ & & & & & & & \\
& & & & & & \\
& $-0.01084^{* * *}$ & -0.00012 & $-0.00036^{* * *}$ & $-0.00027^{* *}$ & $-0.00030^{* * *}$ & $-0.00030^{* * *}$ & $-0.00037^{* * *}$ \\
& $(0.00307)$ & $(0.00042)$ & $(0.00010)$ & $(0.00011)$ & $(0.00011)$ & $(0.00010)$ & $(0.00009)$ \\
\hline R-squared & 0.00612 & 0.00002 & 0.0001 & 0.00001 & 0.00004 & 0.00004 & 0.00006 \\
Obs. & $3,685,235$ & $3,685,235$ & $3,685,235$ & $3,685,235$ & $3,685,235$ & $3,685,235$ & $3,685,235$ \\
Workers & 222,174 & 222,174 & 222,174 & 222,174 & 222,174 & 222,174 & 222,174 \\
Mean of dep. var. & 14.57 & 14.57 & 14.57 & 14.57 & 14.57 & 14.57 & 14.57 \\
Temp. Inv. $\left({ }^{\circ} \mathrm{C}\right)$ & 17.8 & 48.6 & 17.8 & 17.9 & 17.9 & 17.8 & 17.5 \\
Individual FE & No & No & No & No & Yes & Yes & Yes \\
Firm FE & No & No & No & Yes & No & Yes & Yes \\
Municipality FE & No & Yes & Yes & Yes & Yes & Yes & No \\
Year FE & No & Yes & Yes & Yes & Yes & Yes & No \\
Month FE & No & No & Yes & Yes & Yes & Yes & Yes \\
Municipality-Year FE & No & No & No & No & No & No & Yes \\
\hline \hline
\end{tabular}

Notes: Table compares different specifications for the regression of the log of nominal hourly wages on temperature in terms of the inclusion or not of the following fixed effects: worker, firm, municipality, year, month and municipality-year. For the regressions we use a monthly unbalanced sample of Brazilian formal labor market for the years of 2015-2016. Wages are used in nominal terms and its mean is presented in the "Mean of dep. var."line. We also present the adjusted within R-squared of the regression, as well as the number of observations (workers $\mathrm{x}$ months) and the number of workers in the estimating sample. Temperature is included in the model as deviations from climate temperature $(\Delta T e m p)$ and its interaction with climate temperature $((\Delta T e m p) \cdot \bar{T})$. All regressions include precipitation variables as controls and standard errors are clustered by economic region. "Temp. Inv. $\left({ }^{\circ} \mathrm{C}\right)$ " is the temperature inflection point, which is the $\bar{T}$ that makes $\frac{\partial}{\Delta T e m p}\left[\hat{\alpha}_{1} \Delta T e m p+\hat{\alpha}_{2}(\Delta T e m p) . \bar{T}\right]=0$. Our baseline result, that uses real wages instead of nominal wages, was presented in Table 1.4.1. Data sources: labor market data from RAIS 2015-2016 and weather data from Xavier, King e Scanlon (2017). 
Table 1.8.6 - Temperature shocks and wages - Additional robustness checks

\begin{tabular}{lccc}
\hline \hline & $(1)$ & $(2)$ & $(3)$ \\
& Baseline & No Mobility & Balanced Sample \\
\hline$\Delta T e m p$ & $0.01192^{* * *}$ & $0.01223^{* * *}$ & $0.01258^{* * *}$ \\
& $(0.00146)$ & $(0.00157)$ & $(0.00189)$ \\
$(\Delta T e m p) . \bar{T}$ & & & \\
& $-0.00072^{* * *}$ & $-0.00074^{* * *}$ & $-0.00070^{* * *}$ \\
\hline R-squared & $(0.00007)$ & $(0.00008)$ & $(0.00009)$ \\
Obs. & 0.00032 & 0.00035 & 0.00027 \\
Workers & $3,685,235$ & $3,281,811$ & $1,970,601$ \\
Mean of dep. var. & 222,174 & 198,191 & 83,227 \\
Temp. Inv. $\left.{ }^{\circ} \mathrm{C}\right)$ & 13.34 & 13.21 & 15.66 \\
Worker FE & 16.6 & 16.6 & 18.0 \\
Firm FE & Yes & Yes & Yes \\
Month FE & Yes & Yes & Yes \\
Municipality-Year FE & Yes & Yes & Yes \\
\hline \hline
\end{tabular}

Notes: Table shows the results of robustness exercises for the regression of the log of real hourly wages on temperature. Regression (1) presents our baseline result (column 7 of Table 1.4.1), for the sake of comparison. Regression (2) is the same as regression as (1), but restricts the sample to those workers tha did not change municipality, sector or firm between Jan, 2015 and Dec, 2016. Regression (3) is the same as regression (1), but restricts the sample to those workers that remained employed between Jan, 2015 and Dec, 2016. All regressions use our preferred specification (column 7 of Table 1.4.1) which uses worker, firm, month and municipality-year fixed effects. Wages' mean in each regression is presented in the "Mean of dep. var. "line. We also present the adjusted within R-squared of the regressions, as well as the number of observations (workers $\mathrm{x}$ months) and the number of workers in each estimating sample. Temperature is included in the model as deviations from climate temperature $(\Delta T e m p)$ and its interaction with climate temperature $((\Delta T e m p) \cdot \bar{T})$. All regressions include precipitation variables as controls and standard errors are clustered by economic region. "Temp. Inv. $\left({ }^{\circ} \mathrm{C}\right)$ " is the temperature inflection point, which is the $\bar{T}$ that makes $\frac{\partial}{\Delta T e m p}\left[\hat{\alpha}_{1} \Delta T e m p+\hat{\alpha}_{2}(\Delta T e m p) \cdot \bar{T}\right]=0$. Data sources: labor market data from RAIS 2015-2016 and weather data from Xavier, King e Scanlon (2017). 


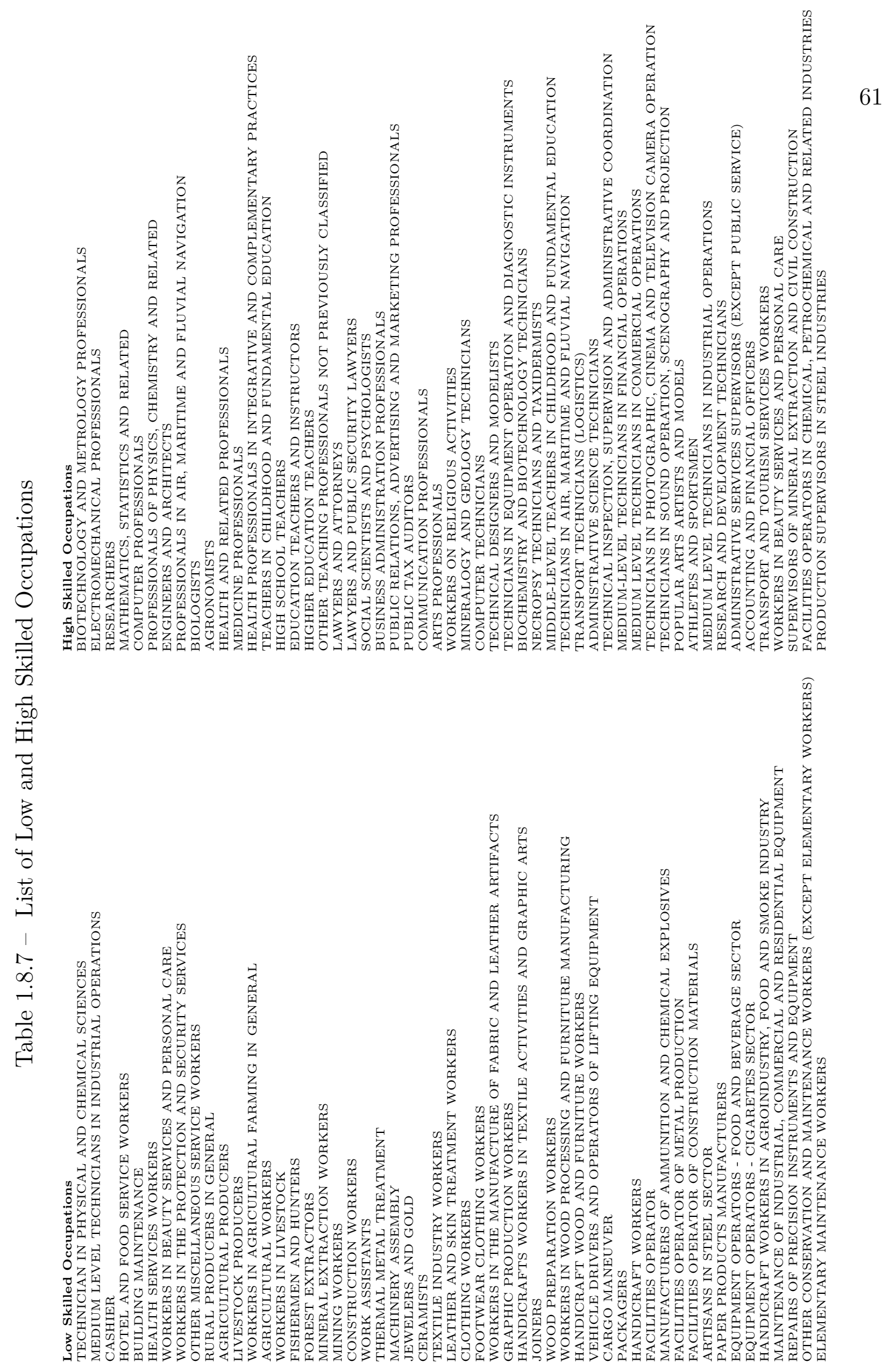


Table 1.8.8 - Temperature shocks and wages - Exposed vs Less exposed occupations

\begin{tabular}{lcc}
\hline \hline & Low Skilled Occup. & High Skilled Occup. \\
\hline$\Delta$ Temp & $0.01285^{* * *}$ & 0.00224 \\
& $(0.00266)$ & $(0.00275)$ \\
$\Delta T e m p) . \bar{T}$ & $-0.00080^{* * *}$ & -0.00017 \\
& $(0.00014)$ & $(0.00013)$ \\
\hline R-squared & 0.00049 & 0.00003 \\
Obs. & 743,185 & 279,874 \\
Workers & 53,005 & 15,485 \\
Mean of dep. var. & 6.99 & 43.08 \\
Temp. Inv. $\left({ }^{\circ} \mathrm{C}\right)$ & 16.1 & 13.3 \\
Worker FE & Yes & Yes \\
Firm FE & Yes & Yes \\
Month FE & Yes & Yes \\
Municipality-Year FE & Yes & Yes \\
\hline \hline
\end{tabular}

Notes: Table shows the results of the regressions of the log of real hourly wages on temperature. We separate the sample in two groups. Low Skilled Occupations represent workers arguably more exposed to the climate and High Skilled Occupations those less exposed. Low Skilled Occupations are defined as the bottom 25th percentile of the occupation wage and education distributions, High Skilled Occupations the top 25th. Both regressions are based on our preferred specification (column 7 of Table 1.4.1) which uses worker, firm, month and municipality-year fixed effects. Temperature is included in the model as deviations from climate temperature $(\Delta T e m p)$ and its interaction with climate temperature $((\Delta T e m p) \cdot \bar{T})$. All regressions include precipitation variables as controls and standard errors are clustered by economic region. "Temp. Inv. $\left({ }^{\circ} \mathrm{C}\right)$ " is the temperature inflection point, which is the $\bar{T}$ that sets $\frac{\partial}{\Delta T e m p}\left[\hat{\alpha}_{1} \Delta T e m p+\hat{\alpha}_{2}(\Delta T e m p) . \bar{T}\right]=0$. Data sources: labor market data from RAIS 2015-2016 and weather data from Xavier, King e Scanlon (2017). 
Table 1.8.9 - Other dependent variables - Low Skilled Occupations only

\begin{tabular}{lcccc}
\hline \hline \multirow{2}{*}{ Panel A: Mobility } & & & & \\
& Municipality & Sector & Firm & Out Lab. Market \\
\hline & & & & \\
$\Delta$ Temp & -0.00038 & -0.00055 & $-0.00084^{*}$ & 0.00036 \\
& $(0.00040)$ & $(0.00036)$ & $(0.00046)$ & $(0.00588)$ \\
$(\Delta T e m p) . \bar{T}$ & 0.00001 & 0.00002 & $0.00004^{*}$ & -0.00043 \\
& $(0.00002)$ & $(0.00002)$ & $(0.00002)$ & $(0.00027)$ \\
\hline R-squared & 0.00004 & 0.00002 & 0.00000 & 0.00056 \\
Obs. & 707,576 & 707,576 & 707,576 & $1,112,510$ \\
Workers & 51,671 & 51,671 & 51,671 & 54,933 \\
Mean of dep. var. & 0.00 & 0.00 & 0.00 & 0.36 \\
Individual FE & Yes & Yes & Yes & Yes \\
Firm FE & Yes & Yes & Yes & Yes \\
Month FE & Yes & Yes & Yes & Yes \\
Municipality-Year FE & Yes & Yes & Yes & Yes \\
\hline
\end{tabular}

Panel B: Employment Outcomes

Log hours Days on leave Permanent job Monthly payment

\begin{tabular}{lcccc}
$\Delta$ Temp & 0.00012 & 0.00576 & -0.00001 & 0.00013 \\
$(\Delta$ Temp $) . \bar{T}$ & $(0.00009)$ & $(0.02509)$ & $(0.00018)$ & $(0.00015)$ \\
& $-0.00001^{*}$ & 0.00006 & -0.00000 & -0.00001 \\
& $(0.00000)$ & $(0.00112)$ & $(0.00001)$ & $(0.00001)$ \\
\hline R-squared & -0.00000 & 0.00000 & -0.00000 & -0.00000 \\
Obs. & 743,185 & 743,185 & 743,185 & 743,185 \\
Workers & 53,005 & 53,005 & 53,005 & 53,005 \\
Mean of dep. var. & 3.76 & 0.25 & 0.98 & 0.93 \\
Individual FE & Yes & Yes & Yes & Yes \\
Firm FE & Yes & Yes & Yes & Yes \\
Month FE & Yes & Yes & Yes & Yes \\
Municipality-Year FE & Yes & Yes & Yes & Yes \\
\hline \hline
\end{tabular}

Notes: Table shows the regressions of several variables related to labor market mobility (Panel A) and employment outcomes (Panel B) on temperature. We restrict our sample to Low Skilled Occupations, which are defined as the bottom 25th percentile of the occupation wage and education distributions. We use our preferred specification, which includes worker, firm, month and municipality-year fixed effects. For the regressions we use a monthly unbalanced sample of the Brazilian formal labor market for the years of 2015-2016. Temperature is included in the models as deviations from climate temperature $(\Delta T e m p)$ and its interaction with climate temperature $((\Delta T e m p) \cdot \bar{T})$. Regressions also include precipitation variables as controls and standard errors are clustered by economic region. These are the same regressions presented in Tables 1.5.1 and 1.6.1, but restricting our sample to Low Skilled Occupations. Data sources: labor market data from RAIS 2015-2016 and weather data from Xavier, King e Scanlon (2017). 
Table 1.8.10 - Other dependent variables - High Skilled Occupations only

\begin{tabular}{lcccc} 
Panel A: Mobility & & & & \\
& Municipality & Sector & Firm & Out Lab. Market \\
\hline \multirow{2}{*}{ Temp } & & & & \\
& 0.00021 & -0.00097 & -0.00115 & 0.00138 \\
$(\Delta T e m p) . \bar{T}$ & $(0.00084)$ & $(0.00116)$ & $(0.00199)$ & $(0.00830)$ \\
& -0.00000 & 0.00006 & 0.00009 & -0.00033 \\
\hline R-squared & $(0.00004)$ & $(0.00006)$ & $(0.00010)$ & $(0.00036)$ \\
Obs. & -0.00000 & 0.00003 & 0.00007 & 0.00025 \\
Workers & 267,690 & 267,690 & 267,690 & 329,007 \\
Mean of dep. var. & 15,303 & 15,303 & 15,303 & 15,666 \\
Individual FE & 0.00 & 0.00 & 0.01 & 0.19 \\
Firm FE & Yes & Yes & Yes & Yes \\
Month FE & Yes & Yes & Yes & Yes \\
Municipality-Year FE & Yes & Yes & Yes & Yes \\
& Yes & Yes & Yes & Yes \\
\hline
\end{tabular}

Panel B: Employment Outcomes

Log hours Days on leave Permanent job Monthly payment

\begin{tabular}{|c|c|c|c|c|}
\hline$\Delta T e m p$ & $\begin{array}{c}0.00025 \\
(0.00034)\end{array}$ & $\begin{array}{c}0.00365 \\
(0.05255)\end{array}$ & $\begin{array}{c}0.00010 \\
(0.00029)\end{array}$ & $\begin{array}{l}-0.00026 \\
(0.00020)\end{array}$ \\
\hline$(\Delta T e m p) \cdot \bar{T}$ & $\begin{array}{l}-0.00001 \\
(0.00002)\end{array}$ & $\begin{array}{c}0.00007 \\
(0.00253)\end{array}$ & $\begin{array}{c}-0.00001 \\
(0.00001)\end{array}$ & $\begin{array}{c}0.00001 \\
(0.00001)\end{array}$ \\
\hline R-squared & -0.00001 & -0.00001 & 0.00000 & -0.00001 \\
\hline Obs. & 279,917 & 279,917 & 279,917 & 279,917 \\
\hline Workers & 15,486 & 15,486 & 15,486 & 15,486 \\
\hline Mean of dep. var. & 3.65 & 0.41 & 0.98 & 0.95 \\
\hline Individual FE & Yes & Yes & Yes & Yes \\
\hline Firm FE & Yes & Yes & Yes & Yes \\
\hline Month FE & Yes & Yes & Yes & Yes \\
\hline Municipality-Year FE & Yes & Yes & Yes & Yes \\
\hline
\end{tabular}

Notes: Table shows the regressions of several variables related to labor market mobility (Panel A) and employment outcomes (Panel B) on temperature. We restrict our sample to High Skilled Occupations, which are defined as the top 25th percentile of the occupation wage and education distributions. We use our preferred specification, which includes worker, firm, month and municipality-year fixed effects. For the regressions we use a monthly unbalanced sample of the Brazilian formal labor market for the years of 2015-2016. Temperature is included in the models as deviations from climate temperature $(\Delta T e m p)$ and its interaction with climate temperature $((\Delta T e m p) \cdot \bar{T})$. Regressions also include precipitation variables as controls and standard errors are clustered by economic region. These are the same regressions presented in Tables 1.5.1 and 1.6.1, but restricting our sample to High Skilled Occupations. Data sources: labor market data from RAIS 2015-2016 and weather data from Xavier, King e Scanlon (2017). 
Table 1.8.11 - Alternative specification - Temperature Bins, Results of Appendix Figure 1.8.6

\begin{tabular}{cc}
\hline \hline & Month FE \\
\hline$<12^{\circ} \mathrm{C}$ & $\begin{array}{c}-0.0004^{* *} \\
(0.0002)\end{array}$ \\
& $\begin{array}{c}-0.0003 \\
12-15^{\circ} \mathrm{C}\end{array}$ \\
& $(0.0002)$ \\
$15-18^{\circ} \mathrm{C}$ & $-0.0003^{* * *}$ \\
& $(0.0001)$ \\
$18-21^{\circ} \mathrm{C}$ & $-0.0002^{*}$ \\
& $(0.0001)$ \\
$21-24^{\circ} \mathrm{C}$ & 0.0000 \\
& $()$. \\
$24-27^{\circ} \mathrm{C}$ & -0.0002 \\
& $(0.0001)$ \\
$27-30^{\circ} \mathrm{C}$ & $-0.0003^{* * *}$ \\
& $(0.0001)$ \\
$>30^{\circ} \mathrm{C}$ & $-0.0007^{* * *}$ \\
& $(0.0002)$ \\
\hline \hline
\end{tabular}

Notes: Table presents the results of Appendix Figure 1.8.6. Data sources: labor market data from RAIS 2015-2016 and weather data from Xavier, King e Scanlon (2017). 



\title{
2 Does weather influence COVID-19 transmission?
}

\author{
With Paula Pereda and Carlos Azzoni
}

\subsection{Introduction}

The first case of severe acute respiratory disease caused by the SARS-CoV-2 virus, or COVID-19, was reported on December 12, 2019 in Wuhan, China (Wu et al. (2020); Zhou et al. (2020)). By October, 2020, the world already had more than 40 million confirmed cases and more than 1,1 million deaths, and numbers were rapidly increasing (John Hopkins University (2020)). In response to the pandemic, one-third of the global population took some form of social distancing or even lockdown measure in the first half of 2020 (Business Insider (2020)). The economic impacts of the pandemic and the net benefits of these closure policies are under debate, but there are still many uncertainties regarding the current models (Fernandes (2020); Thunström et al. (2020)). Many factors are crucial to understand the length of the pandemic, which can affect the contagion rate and, therefore, the timing of economic reopening of regions or countries. Among these factors is the weather, but there is still mixed scientific evidence on how it affects the SARS-CoV-2 transmission.

To contribute to the current debate of the weather's effects on COVID-19 cases, especially as the Northern Hemisphere approaches warmer weather, and to help governments define economic recovery strategies, we explore a global daily panel of 416 regions and 93 days of confirmed cases of COVID-19 and weather data. We gathered data on the first four months of the pandemic at the global level and the richness of the dataset allows us to explore the time variation within regions to identify the effects of temperature and humidity on cases of COVID-19.

We find evidence that an increase in temperature of $1^{\circ} \mathrm{C}$ can reduce the virus transmission up to $8.98 \%$ on average. Humidity and precipitation also seem to negatively impact transmission, but their effects are close to zero. We further assess the heterogeneity of the climatic temperature effects to understand whether 
the seasonal change might affect the transmission of the disease. We find that the effect of temperature is stronger in cold climates, reaching $12.86 \%$, in arid climates, reducing cases up to $12.08 \%$, and in dry climates, with a decline of $10.08 \%$ in cases ${ }^{2.1 .1}$.

Three studies have found no relation between temperature and the spread of the virus in China (Jüni et al. (2020); Xie e Zhu (2020); Yao et al. (2020)), but the majority of the recent literature on the subject supports significant relationships between the SARS-CoV-2 transmission and weather, mainly temperature and humidity. The spread of the virus has been found to be negatively affected by high temperature and high humidity (Araujo e Naimi (2020); Confalonieri et al. (2020); Ficetola e Rubolini (2020); Sajadi et al. (2020); Wang et al. (2020)) or just by high temperature (Tosepu et al. (2020)).Many of the works point out similarities between this new virus and its predecessor, SARS-CoV-1, whose propagation was also negatively affected by high temperature and high humidity (Tan et al. (2005)) and by high temperature alone (Lin et al. (2006)). The idea is that the physical stability of the pathogen is lost when exposed to certain levels of temperature and humidity (Chan et al. (2011)).

We add to this literature by using a global daily panel of confirmed cases and weather data and find relevant effects of weather on transmission. Our empirical strategy is better than that of studies published so far because it uses time and region fixed effects, as well as region-month fixed effects to control for possible confounders. We also innovate by using a more detailed (416 regions) and longer (93 days) global panel than other studies.

This paper is divided into five sections, including this introduction. Section 2.2 presents the COVID-19 and weather databases used in the study, along with the empirical model. Section 2.3 discusses the association of temperature, humidity and precipitation with the number of COVID-19 cases. Temperature effects are further analyzed in terms of the levels of climate variables. Finally, Section 2.4 discusses the results and policy implications.

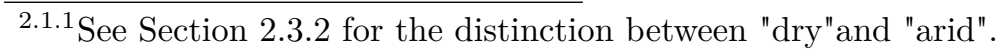




\subsection{Data and empirical strategy}

Our empirical strategy consists of exploring the exogenous variation of weather within regions of the world to understand if it somehow is associated with the propagation of the SARS-CoV-2 virus. We do this by regressing the log of confirmed cases of COVID-19 against lags of temperature, humidity and precipitation. In this section, we first provide information regarding the data sources and data construction. Then, we present the model used to estimate the association of weather with virus transmission.

\subsubsection{Databases}

The weather variables used in the estimations come from the International Research Institute for Climate and Society (IRI) of Columbia University. The freely accessible IRI/LDEO Climate Data Library congregates weather information from several official sources around the world ${ }^{2.2 .1}$ in a common system.

We use daily COVID-19 information of cumulative confirmed cases at the regional level ${ }^{2.2 .2}$ from the COVID-19 Data Repository by the Center for Systems Science and Engineering (CSSE) at Johns Hopkins University (for world data) and from the Sito del Dipartimento della Protezione Civile - Emergenza Coronavirus: la risposta nazionale (for data from Italy) (Dipartimento della Protezione Civile (2020); John Hopkins University (2020)). Together the bases cover a total 416 regions, including 186 countries and provinces or states of several countries.

Figure 2.2.1 presents the evolution of confirmed COVID-19 cases for selected countries among the most infected until April 23, 2020. The United States was by far the most affected country at that point in time, reaching almost one million

\footnotetext{
${ }^{2.2 .1}$ It includes meteorological authorities from Australia, Brazil, Canada Chile, Japan, United States and others.

${ }^{2.2 .2}$ Which is one level below country level. It can be called state or province, depending on the country. Regional level data were available for the following countries: Canada, China, France, Italy, Netherlands, United Kingdom and United States. A complete list of the countries and provinces/states considered in this paper can be found, respectively, in the Appendix Tables 2.4.3 and 2.4.4.
} 
cases, followed by Spain and Italy. Figure 2.4.1, Figure 2.4.2 and Figure 2.4.3 present further descriptive statistics of the disease.

Figure 2.2.1 - Log of confirmed cases for selected countries, Jan-Apr 2020

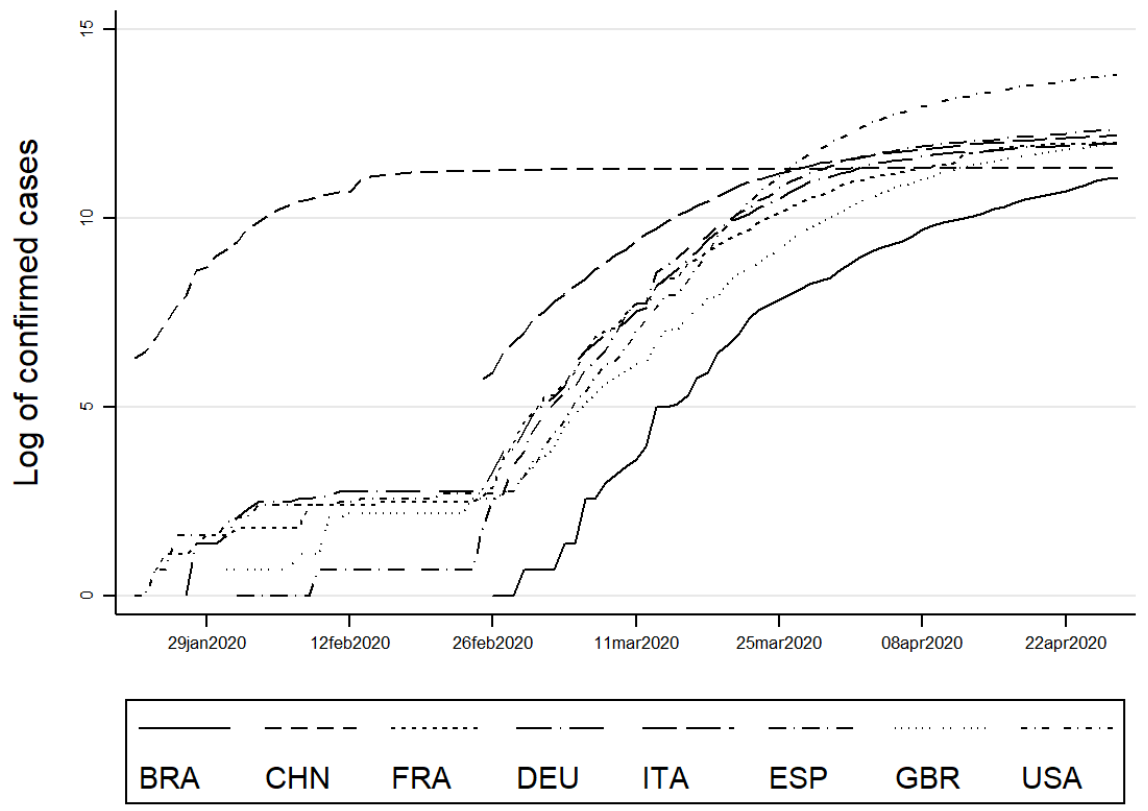

Notes: The figure shows the evolution of confirmed COVID-19 cases in selected countries from the first case until April 23, 2020. The United States had almost four times the number of cases as Spain, the second most affected country at that date.

We match the daily COVID-19 information with weather and climate variables from the International Research Institute for Climate and Society (IRI) of Columbia University. The freely accessible IRI/LDEO Climate Data Library congregates weather information from several official sources around the world ${ }^{2.2 .3}$ in a common system. We use the daily $2 \times 2$ degree latitude-longitude grid of global weather information provided by the National Oceanic and Atmospheric Administration (NOAA), for temperature, specific humidity ${ }^{2.2 .4}$, and precipitation, ${ }^{2.2 .3}$ It includes meteorological authorities from Australia, Brazil, Canada, Chile, Japan, United States and others.

${ }^{2.2 .4}$ Specific humidity, as collected by NOAA, is defined as the ratio of the mass of water vapor (moist air) to the total mass of the system (air and water vapor), but it can be interpreted in percentage terms. 
from January 1, 1990, to April 23, 2020.

We consider "weather" as the daily data available between February 22, 2020, and April 23, 20202.2.5 . We also calculate the long-term averages of weather variables using monthly averages (all 12 months of the year) for the period between 1990 and 2019. We refer to the long-term average as "climate" to differentiate from the daily weather and use them to perform heterogeneity exercises ${ }^{2.2 .6}$. Figure 2.2.2, Figure 2.2.3 and Figure 2.2.4 present weather distributions of temperature, humidity, and precipitation, respectively.

Figure 2.2.2 - Temperature distribution $\left({ }^{\circ} \mathrm{C}\right)$ - Weather

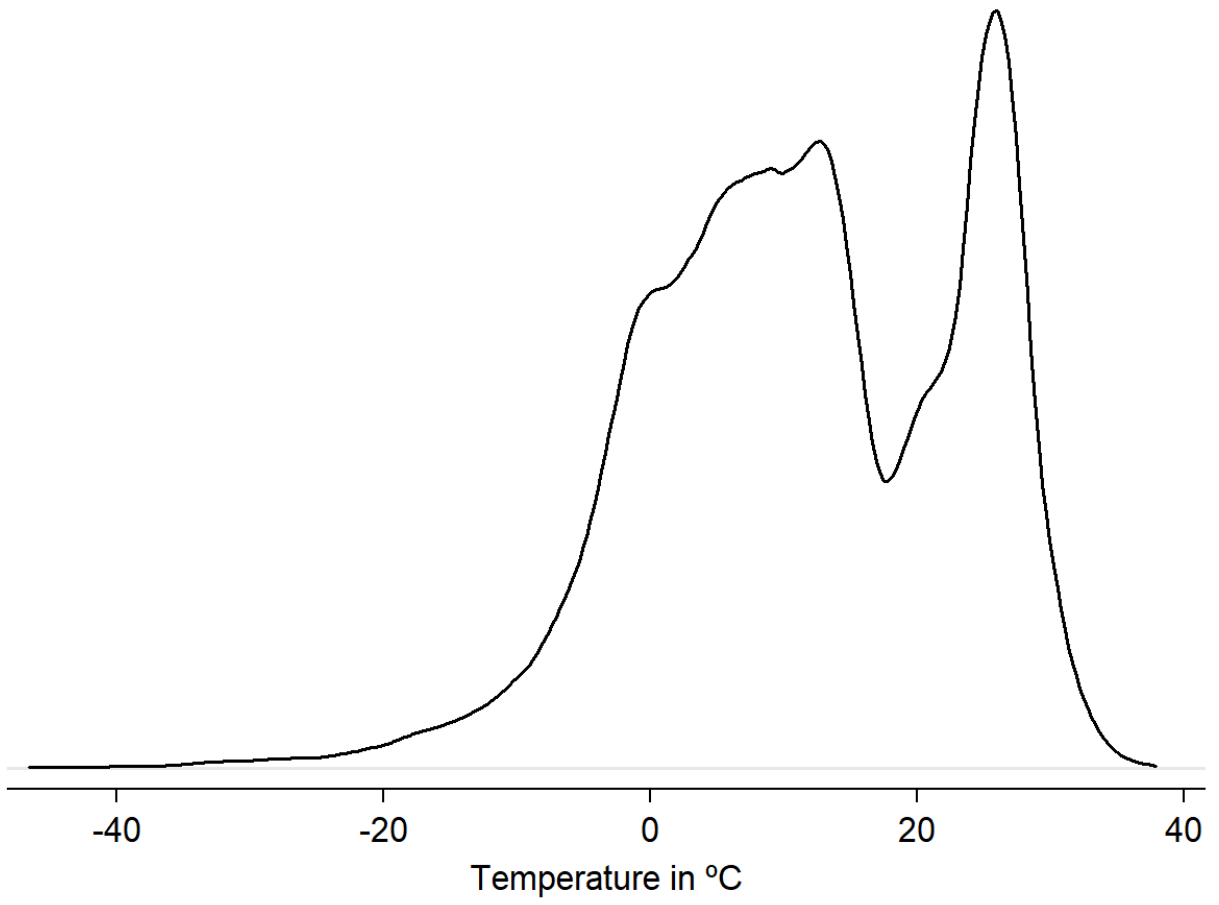

Notes: The figure shows temperature distribution in ${ }^{\circ} \mathrm{C}$ of our sample (416 countries or regions) for weather. Weather is the daily distribution of temperature between February 22, 2020 and April 23, 2020.

${ }^{2.2 .5}$ The most recent weather variables were restricted to the period from January 22 to April 23, 2020 (93 days) until the finalization of this paper.

2.2.6 The Table 2.4.1 provide descriptive statistics of the climate variables. 
Figure 2.2.3 - Specific humidity distribution (\%) - Weather

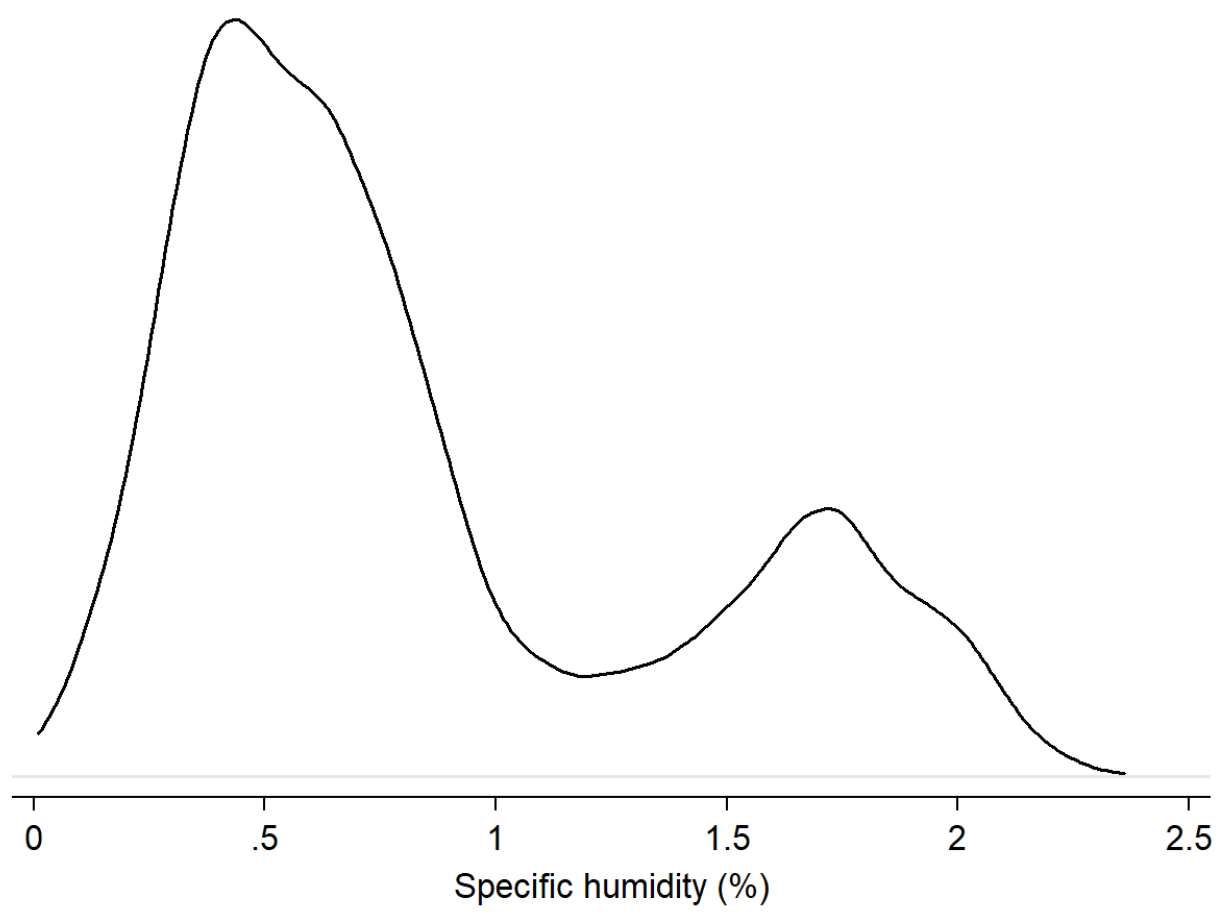

Notes: The figure shows specific humidity distribution in our sample (416 countries or regions) for weather. Specific humidity is defined as the ratio of the mass of water vapor (moist air) to the total mass of the system (air and water vapor), but it can be interpreted in percentage terms. Weather is the daily distribution of specific humidity between February 22, 2020 and April 23, 2020. 
Figure 2.2.4 - Precipitation distribution (mm/day) - Weather

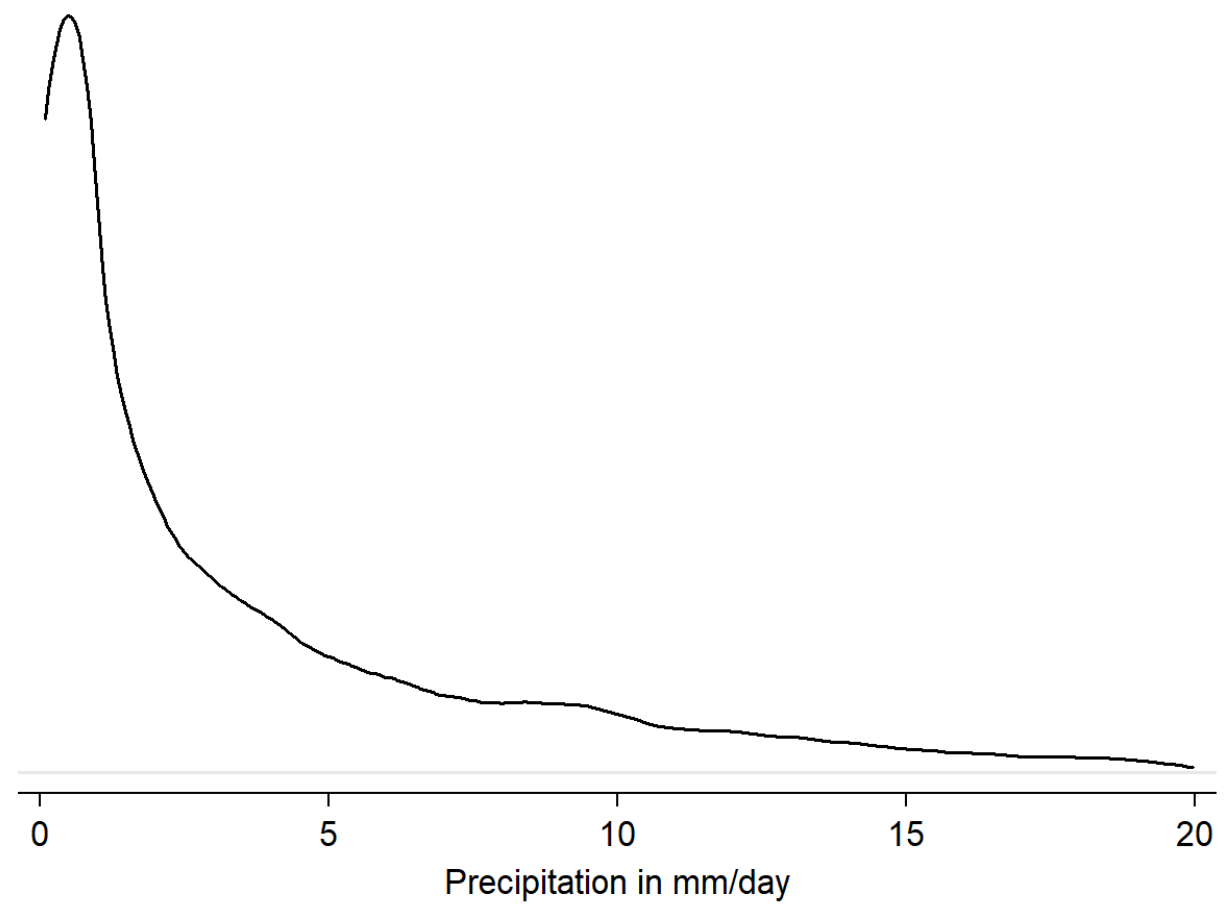

Notes: The figure shows precipitation distribution in $\mathrm{mm} /$ day of our sample (416 countries or regions) for weather. Weather is the daily distribution of precipitation between February 22, 2020 and April 23, 2020.

The weather temperature distribution is bimodal since the January-April period was mostly winter in the Northern Hemisphere and summer in the Southern Hemisphere. The same can be said about specific humidity because the Northern Hemisphere was in the dry season while the Southern Hemisphere was in the rainy season. The precipitation distribution is positively skewed since there is little rain in most of the days and a few days with heavy rain. Table 2.2.1 presents summary statistics of these weather variables. 
Table 2.2.1 - Summary statistics for weather temperature, humidity and precipitation

\begin{tabular}{|c|c|c|c|c|c|}
\hline Variable & Mean & Std. Dev. & Min & Max & Observations \\
\hline \multicolumn{6}{|c|}{ Temperature levels $\left({ }^{\circ} \mathrm{C}\right)$} \\
\hline Overall & 11.55 & 11.78 & -46.55 & 37.85 & $N=38688$ \\
\hline Between & & 11.16 & -30.41 & 31.18 & $n=416$ \\
\hline Within & & 3.81 & -12.92 & 31.14 & $\mathrm{~T}=93$ \\
\hline \multicolumn{6}{|c|}{ Humidity levels (\%) } \\
\hline Overall & 0.84 & 0.55 & 0.01 & 2.36 & $N=38688$ \\
\hline Between & & 0.52 & 0.06 & 2.17 & $n=416$ \\
\hline Within & & 0.17 & -0.16 & 2.00 & $T=93$ \\
\hline \multicolumn{6}{|c|}{ Precipitation levels (mm/day) } \\
\hline Overall & 2.13 & 4.58 & 0 & 61.43 & $N=38688$ \\
\hline Between & & 2.06 & 0 & 13.54 & $n=416$ \\
\hline Within & & 4.09 & -10.74 & 59.58 & $\mathrm{~T}=93$ \\
\hline
\end{tabular}

Notes: The table shows summary statistics of all weather variables of our sample of 416 countries or regions. The temperature variables are presented in ${ }^{\circ} \mathrm{C}$, while the specific humidity variables are presented in $\%$ and the precipitation variables in $\mathrm{mm} /$ day. Weather variables are those collected between February 22, 2020 and April 23, 2020

The NOAA's measure of specific humidity has a narrow range, from $0.01 \%$ to $2.36 \%$. This is a characteristic of this variable, since the amount of moist air is always very small in the system. For this reason, we use intervals of 0.01 percentage point to analyze this variable when discussing the results. For temperature and precipitation, which are more common and intuitive, we use $1^{\circ} \mathrm{C}$ /day and $1 \mathrm{~mm} /$ day intervals.

To match COVID-19 data with weather-climate data we used the latitude and longitude centroid of the regions/countries available in the database (John Hopkins University (2020)). We found the closest available weather information of the NOAAS' grid to the centroids using the "gdistance" package in $\mathrm{R}^{2.2 .7}$, that calculates the cartesian minimum distance between the weather grid and the centroids.

${ }^{2.2 .7}$ https://www.rdocumentation.org/packages/rgeos/versions/0.5-3/topics/gDistance 


\subsubsection{Empirical strategy}

We use a panel model with $15 \operatorname{lags}^{2.2 .8}$ and test the weather effect based on the following equation::

$$
\ln \left(y_{r t}\right)=\alpha_{0}+\beta_{i} \sum_{i=0}^{15} \text { Temperature }_{r t-i}+\theta_{i} \sum_{i=0}^{15} \text { Precipitation }_{r t-i}+\alpha_{t}+\theta_{r m}+\epsilon_{r t}
$$

Where $y_{r t}$ is confirmed cases of COVID-19 in region $\mathrm{r}$ and day t; Temperature ${ }_{r t-i}$ is the lagged temperature; and Precipitation ${ }_{r t-i}$ is the lagged precipitation used as control ${ }^{2.2 .9}$.

We use the natural logarithm transformation of the dependent variable since it showed an exponential trend in the period under analysis ${ }^{2.2 .10}$.

The use of lags of weather variables in the model is justified for several reasons. For example, the time between exposure to the SARS-CoV-2 virus and the moment the symptoms of the disease start to appear, which is five or six days on average (World Health Organization (2020)), as well as the delay to obtain test results. Weather can impose restrictions on the viral infection, but since our dependent variable actually measures the number of people declared sick by the health authorities, the lags are necessary to capture the time span between infection and manifestation of symptoms. Still, our empirical exercise does not aim to precisely identify these time spans, but only the overall effect of weather on the spread of the disease, measured by the sum of the 15 lags in the model, plus the contemporaneous effect (16 coefficients in total). We further explore this aspect when presenting our results.

The day and region-month fixed effects are, respectively, $\alpha_{t}$ and $\theta_{r m}$. They control for factors that may affect our dependent variable in any given day $t$ or

\footnotetext{
${ }^{2.2 .8}$ We change the number of lags in robustness checks.

${ }^{2.2 .9}$ We perform alternative exercises using specific humidity and precipitation as independent variables in the Appendix B. In these cases, we do not use precipitation as control in the regressions.

${ }^{2.2 .10}$ As our model uses the logarithm transformation of the confirmed cases as dependent variable, days with zero confirmed cases (i.e. before the virus spread) are not considered in the regressions. In other words, for each region/country we consider the start of the pandemic when there was at least 1 confirmed case.
} 
region $\mathrm{rm}$. For example, $\alpha_{t}$ controls for omitted variables that can affect all regions on any given day, such as updating of reports that typically occurs after weekends or local holidays. Similarly, $\theta_{r m}$ controls for unobserved effects that differ across regions but are constant on any given day, such as the containment measures that many countries took in the middle of March to reduce the virus's propagation.

All regressions' standard errors are clustered by region/country and are weighted by the population in that area in 2019. As the populations for specific regions were not available, we divided the population of the country equally among the regions of that country. See Table 2.4.4 for the list of those countries. This strategy is common in the microeconometric literature to weight units based on their exposition to the effects analyzed. The general idea is that countries/regions with more people will be more affected by the weather variations.

Weather variations are expected to be exogenous when compared to COVID19 transmission rates. For this reason, we argue that the time and fixed effects used in the model are enough to allow us to interpret the results as effects of weather on transmission, and not simply correlations. The next section presents the results of the estimations. 


\subsection{Results}

In this section, we present the results, in two subsections. In the first one, we analyze how the lags of our weather variables relate to the transmission of the virus. We show that temperature is much more relevant in explaining a reduction in transmission than humidity and precipitation. In the second subsection, we further separate temperature effects by levels, high or low, of the climate variables. The objective is to evaluate if the temperature impacts on transmission are different when temperature, humidity and precipitation were historically high or low. A third subsection summarizes the results and a final subsection present robustness exercises.

\subsubsection{Main results}

We begin by presenting the results of temperature, lagged from 1 to 15 days plus the contemporaneous effect, with four different specifications (Table 2.3.1). First, we present an ordinary least square (OLS) regression, which shows a nonexistent relationship between temperature and confirmed cases. Second, we include day fixed effects to account for possible omitted variables that influence all regions on a given day, finding that the significance level of some coefficients increases. Third, we further control for region fixed effects to account for unobserved effects that may differ across regions. In this case, it clearly shows a negative effect of temperature lags on the log of confirmed cases, but none of them are significant. Finally, the fourth column displays our preferred specification, which also includes region-month fixed effects, it increases the magnitude of the coefficients and the overall effect on transmission reaches a $9 \%$ decrease per $1{ }^{\circ} \mathrm{C}$ increase.

In our preferred specification (Column 4), we are using day and region-month fixed effects. The sum of all lags of the model is our main measure of the impacts of weather on the virus transmission since we do not aim to explain the rationale behind the effect of every individual lag. However, we provide some possible and non-exhaustive explanations on this subject. The majority of the lags between one and six are significant, which is consistent with the idea that it takes five to six 
days between contracting the virus and appearance of the first symptoms, plus a couple of days to test and confirm the diagnosis of COVID-19 (World Health Organization (2020)). We are also aware that many countries were having trouble in testing because of the lack of sufficient supplies and the consequent accumulation of samples waiting to be tested (The New York Times (2020)). This effect may cancel the negative effects of climate, causing the non-significance of some higher lags. Also, there may be some behavioral effect taking place since there is anecdotal evidence of people ignoring isolation when the weather is favorable, going to beaches and open spaces. 
Table 2.3.1 - Impacts of temperature on COVID-19 confirmed cases, Jan to Apr 2020

\begin{tabular}{|c|c|c|c|c|}
\hline & $\begin{array}{l}(1) \\
\text { OLS }\end{array}$ & $\begin{array}{l}(2) \\
(1)+\text { Day FE }\end{array}$ & $\begin{array}{l}(3) \\
(2)+\text { Reg. FE }\end{array}$ & $\begin{array}{l}(4) \\
(3)+\text { Region-Month FE }\end{array}$ \\
\hline Temp $p_{t}$ & 0.0185 & 0.0215 & -0.0039 & $-0.0224^{* * *}$ \\
\hline$T e m p_{t-1}$ & -0.0047 & -0.0025 & -0.0040 & $-0.0062^{* *}$ \\
\hline$T e m p_{t-2}$ & $0.0115^{*}$ & 0.0054 & -0.0026 & $-0.0105^{* * *}$ \\
\hline Temp $p_{t-3}$ & 0.0019 & -0.0008 & -0.0058 & $-0.0062^{*}$ \\
\hline Temp $p_{t-4}$ & 0.0054 & -0.0009 & -0.0068 & $-0.0080^{* *}$ \\
\hline$T e m p_{t-5}$ & 0.0036 & 0.0028 & -0.0032 & $-0.0085^{* *}$ \\
\hline Temp $p_{t-6}$ & $-0.0051^{*}$ & -0.0021 & -0.0068 & $-0.0109 * * *$ \\
\hline$T e m p_{t-7}$ & $0.0105^{*}$ & 0.0009 & -0.0012 & -0.0031 \\
\hline$T e m p_{t-8}$ & -0.0031 & -0.0041 & -0.0059 & -0.0062 \\
\hline Temp $p_{t-9}$ & 0.0034 & -0.0010 & 0.0009 & -0.0038 \\
\hline Temp $_{t-10}$ & -0.0021 & -0.0048 & -0.0050 & -0.0037 \\
\hline Temp $p_{t-11}$ & 0.0006 & -0.0023 & -0.0000 & 0.0032 \\
\hline Temp $p_{t-12}$ & -0.0077 & $-0.0077 * *$ & -0.0056 & 0.0035 \\
\hline Temp $_{t-13}$ & $-0.0085^{* *}$ & $-0.0107^{* * *}$ & -0.0068 & -0.0000 \\
\hline Temp $p_{t-14}$ & 0.0032 & -0.0017 & -0.0025 & 0.0038 \\
\hline$T e m p_{t-15}$ & $-0.0242^{*}$ & $-0.0237^{* * *}$ & -0.0079 & -0.0076 \\
\hline Observations & 21238 & 21238 & 21238 & 21223 \\
\hline$R^{2}$ & 0.01 & 0.43 & 0.77 & 0.95 \\
\hline$\sum_{t=0}^{15} \hat{\beta}_{l}$ & 0.00 & $-0.03^{*}$ & -0.07 & $-0.09 * *$ \\
\hline Mean of dep. var. & 2,664 & 2,664 & 2,664 & 2,664 \\
\hline Prec.Control & Yes & Yes & Yes & Yes \\
\hline
\end{tabular}

Notes: The table shows the three main specifications analyzed in this work and cases of COVID-19 are in logarithm. The first is a standard ordinary least square regression (OLS) with 15 temperature lags and no fixed effects. The second regression shows the results of including time fixed effects in the OLS model. The third regression includes region fixed effects. Finally, the fourth and preferred regression uses region-month, instead of only region fixed effects. All regressions include precipitation controls (using the same lag structure as temperature variables) and all standard errors are clustered by region/country. All regressions are weighted by the population of that area in 2019. The table also shows the number of observations used in each model, along with the $R^{2}$ value and the average number of COVID-19 cases in the regions (mean of dep. var.). To calculate the number of average cases, we consider only positive values since, the log transformation of the dependent variable excludes days with zero confirmed cases. Finally, we also present the significance test for the sum of the 15 lags $\left(\sum_{t=0}^{15} \hat{\beta}_{l}\right) .{ }^{*} \mathrm{p}<0.10,{ }^{* *} \mathrm{p}<0.05,{ }^{* * *} \mathrm{p}<0.01$ 
Thus, to determine the magnitude of the effects of temperature on COVID19 transmission, we use our preferred specification and test the significance of temperature effects on confirmed cases in sets of five consecutive lags, except for the first set, that also consider the contemporaneous effect (therefore, six lags total). We test if the sum of lags zero to five is significant; then we test the sum six to ten lags, and finally eleven to fifteen lags. The idea is to smooth the effects of these lags, which are probably capturing some of the effects we explained above. The results are depicted in Figure 2.3.1 for better visualization ${ }^{2.3 .1}$. We found that the effects of temperature on reducing the transmission occur in the first six lags. This evidence is consistent with the finding of Tan et al. (2005), who also reported a significant correlation between the SARS-CoV-1 and environmental temperature seven days before transmission. We replicated the analysis for humidity and precipitation. They were not significant in reducing the virus transmission. We present further details of these estimates in the Appendix B.

${ }^{2.3 .1}$ As the dependent variable is in logs, coefficients should be multiplied by 100 and interpreted as percentage points. For example, a negative 0.025 coefficient means approximately a $2.5 \%$ decrease in the virus transmission. 
Figure 2.3.1 - Impacts of temperature on COVID-19 confirmed cases in sets of five lags, Jan-Apr 2020

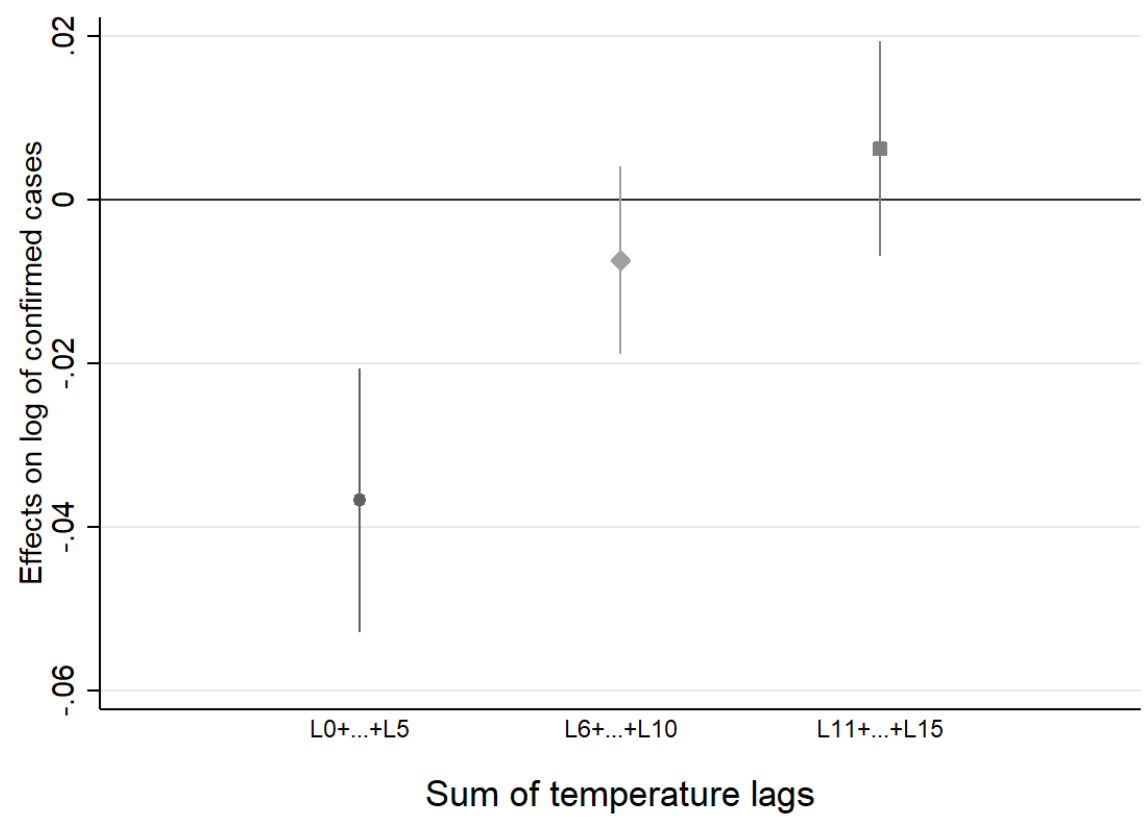

Notes: The figure shows the results of our preferred specification, which includes time and region fixed effects in the OLS model. We test and present the sum of temperature lags in sets of five (six, for the first 6 lags), along with the 95\% confidence interval. All standard errors are clustered by region/country and all regressions are weighted by the population of that area in 2019 .

In the next section, we check if temperature influences COVID-19 transmission in the same way when climate temperature, humidity and precipitation are historically high or low.

\subsubsection{Heterogeneity: Different climates}

Outbreaks of viral respiratory diseases such as influenza and SARS-CoV1 typically occur in winter and dry seasons (Confalonieri et al. (2020)). This may indicate that countries with specific climate conditions are possibly more susceptible to this kind of infection, including the SARS-CoV-2. So, in order to test this hypothesis, we check in this section if temperature impacts transmission 
in the same way when we split our sample in two, using the climate conditions. The idea is to test whether historically cold, dry and arid regions may benefit more from temperature impacts than warmer, moister and wetter regions. This does not mean that the sample median is somehow related to any characteristic of the virus, it is just a way to test our hypothesis relying in variables that have no correlation to the infections ${ }^{2.3 .2}$.

First, we split the sample in half using the median climate temperature. We call "warm" those regions that presented an average monthly temperature above $15.3^{\circ} \mathrm{C}$ between 1990 and 2019 . These are regions historically above the median in our sample. Conversely, we call "cold"those regions with below-median $\left(15.3^{\circ} \mathrm{C}\right)$ average temperature in the same period. Figure 2.3.2 shows the effects of temperature on the log of confirmed cases for the two cases of climate temperature.

Again, based on the results of our preferred specification, which is an OLS with day and region-month fixed effects, we test the significance of temperature effects on confirmed cases in sets of five consecutive lags for each group (warm and cold).

In this setup, temperature plays a more important role in diminishing the virus transmission in cold regions. In these, six consecutive days with $1^{\circ} \mathrm{C}$ higher temperature are associated with a $0.082\left[C I_{95 \%}: 0.043-0.120\right]$ drop in the transmission. In warm regions, six consecutive days with $1^{\circ} \mathrm{C}$ higher temperature do not reduce transmission.

\footnotetext{
2.3.2 The short-term weather variations may be linked to the virus transmission, but the long-term (climate) variables, calculated as monthly averages from 1990 to 2019, are certainly not linked to the infections occurred in 2020.
} 
Figure 2.3.2 - Impacts of temperature on COVID-19 confirmed cases - Warm and Cold climates, Jan-Apr 2020

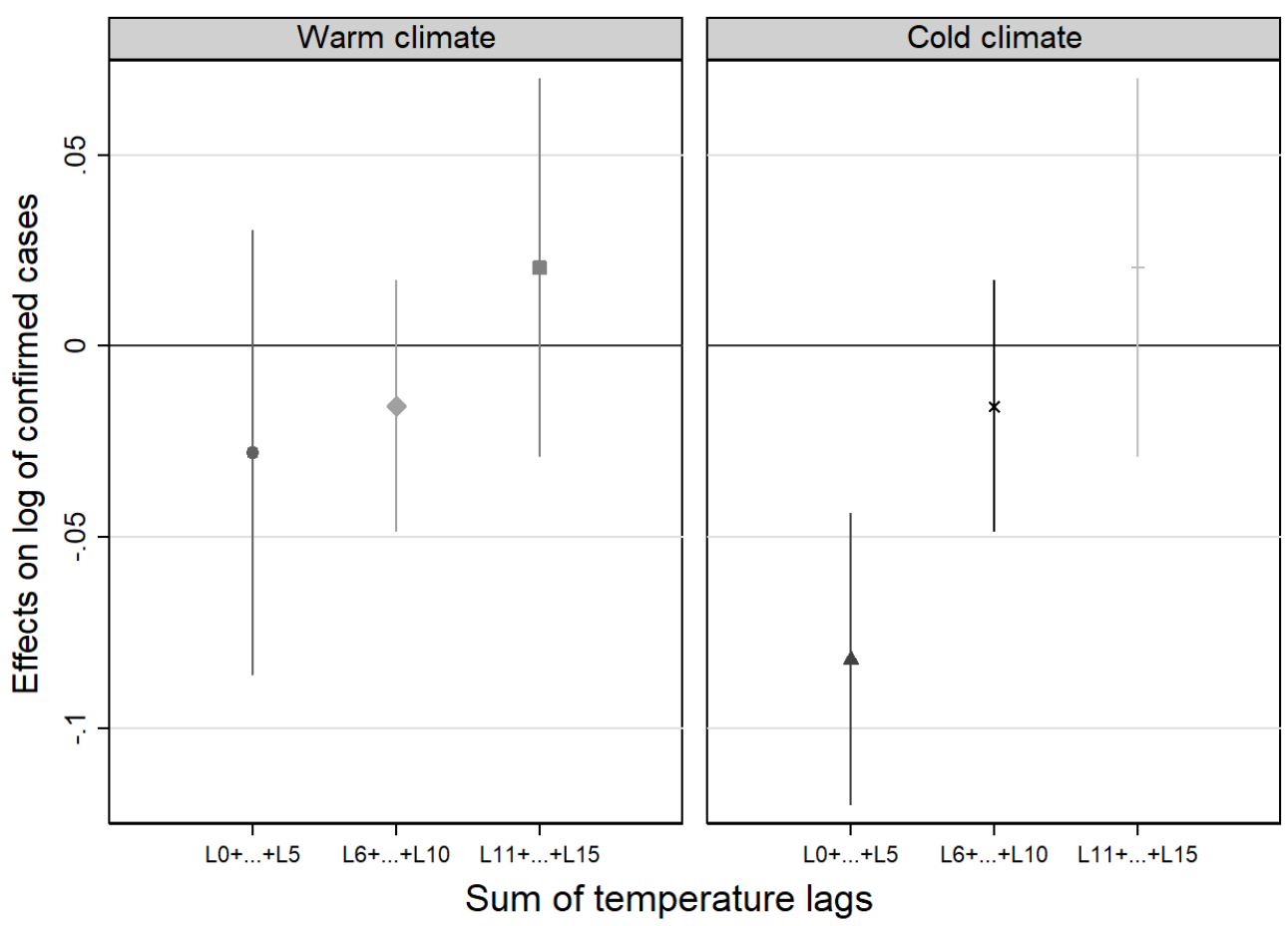

Notes: The figure shows the results of preferred specification, which includes day and region-month fixed effects in the OLS model. We test and present the sum of temperature lags in sets of five (six, for the first 6 lags), along with the $95 \%$ confidence interval, separated in two by the median of the climate temperature $\left(15.3^{\circ} \mathrm{C}\right)$. All standard errors are clustered by region/country and all regressions are weighted by the population of that area in 2019. The average number of cases for the "Warm climate" group is 683 and 3,703 in the "Cold climate" group. To calculate the number of average cases, we consider only positive values, since the log transformation of the dependent variable excludes days with zero confirmed cases.

Second, we split the sample in half using the median of climate humidity. We call "moist"those regions that presented an average monthly specific humidity above $0.91 \%$ in the period between 1990 and 2019; conversely, we call "dry"those regions whose average humidity stayed below the median. Figure 2.3.3 shows the effects of temperature on the log of confirmed cases in these two cases.

The results in terms of case reduction indicate that temperature plays a 
more important role in diminishing the virus transmission in dry regions. In these regions, six consecutive days with $1^{\circ} \mathrm{C}$ higher temperatures are associated with a $0.063\left[C I_{95 \%}: 0.021-0.106\right]$ drop in the transmission. In moist regions, six consecutive days with $1^{\circ} \mathrm{C}$ higher temperature do not tend to reduce transmission.

Figure 2.3.3 - Impacts of temperature on COVID-19 confirmed cases - Moist and Dry climates, Jan-Apr 2020

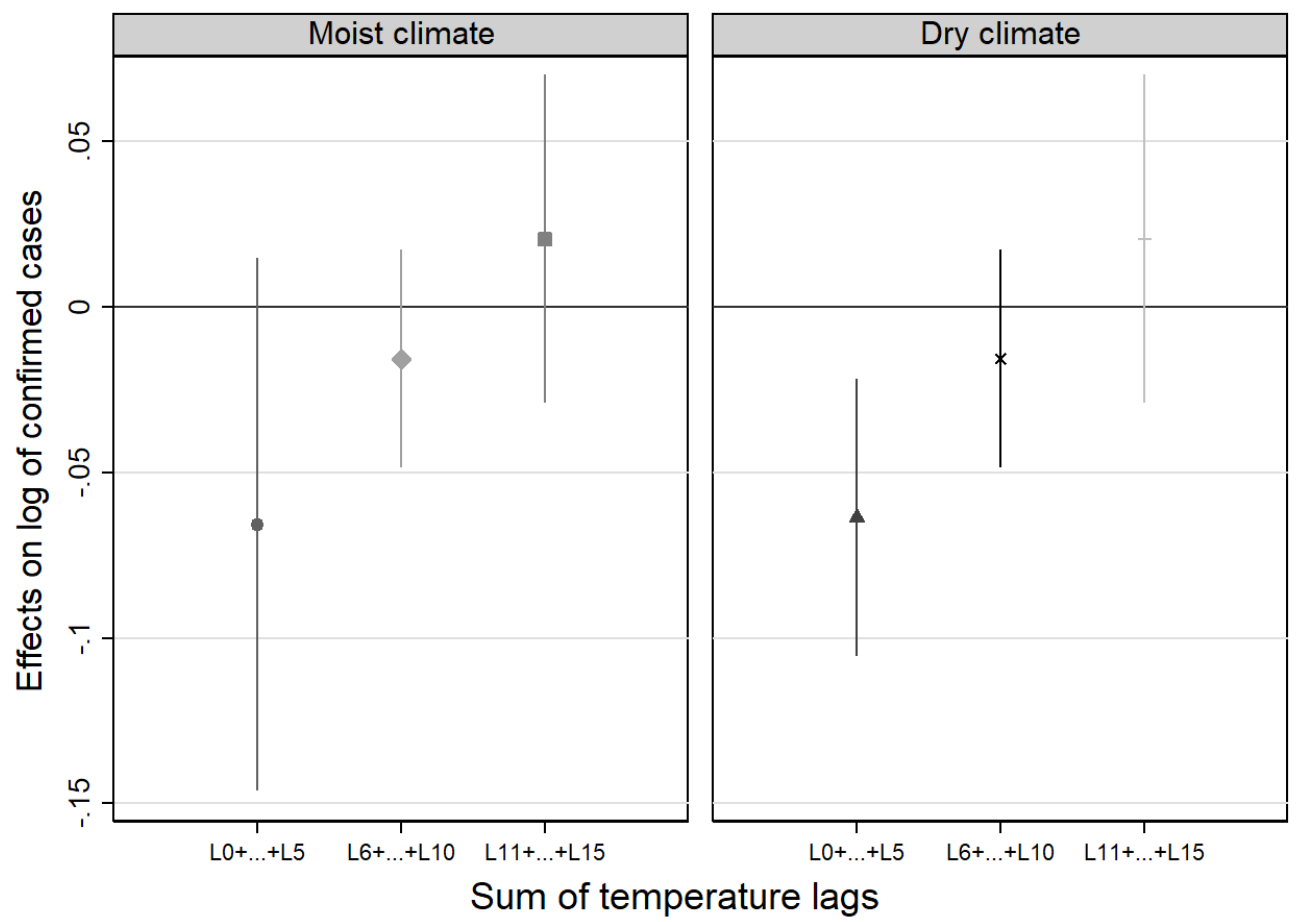

Notes: The figure shows the results of our preferred specification, which includes day and regionmonth fixed effects in the OLS model. We test and present the sum of temperature lags in sets of five (six, for the first 6 lags), along with the $95 \%$ confidence interval, separated in two by the median of the climate specific humidity (0.91\%). All standard errors are clustered by region/country and all regressions are weighted by the population of that area in 2019. The average number of cases for the "Moist climate" group is 1,163 and 3,403 in the "Dry climate" group. To calculate the number of average cases, we consider only positive values, since the log transformation of the dependent variable excludes days with zero confirmed cases.

Third, we split our sample in half using the median of the climate precipitation variable. We call "wet"those regions that presented average monthly 
precipitation above $2.51 \mathrm{~mm}$ /day in the period between 1990 until 2019; conversely, we call "arid"those regions whose average precipitation stayed below the median. Figure 2.3.4 shows the effects of temperature on the log of confirmed cases in those situations.

Figure 2.3.4 - Impacts of temperature on COVID-19 confirmed cases - Wet and Arid climates, Jan-Apr 2020

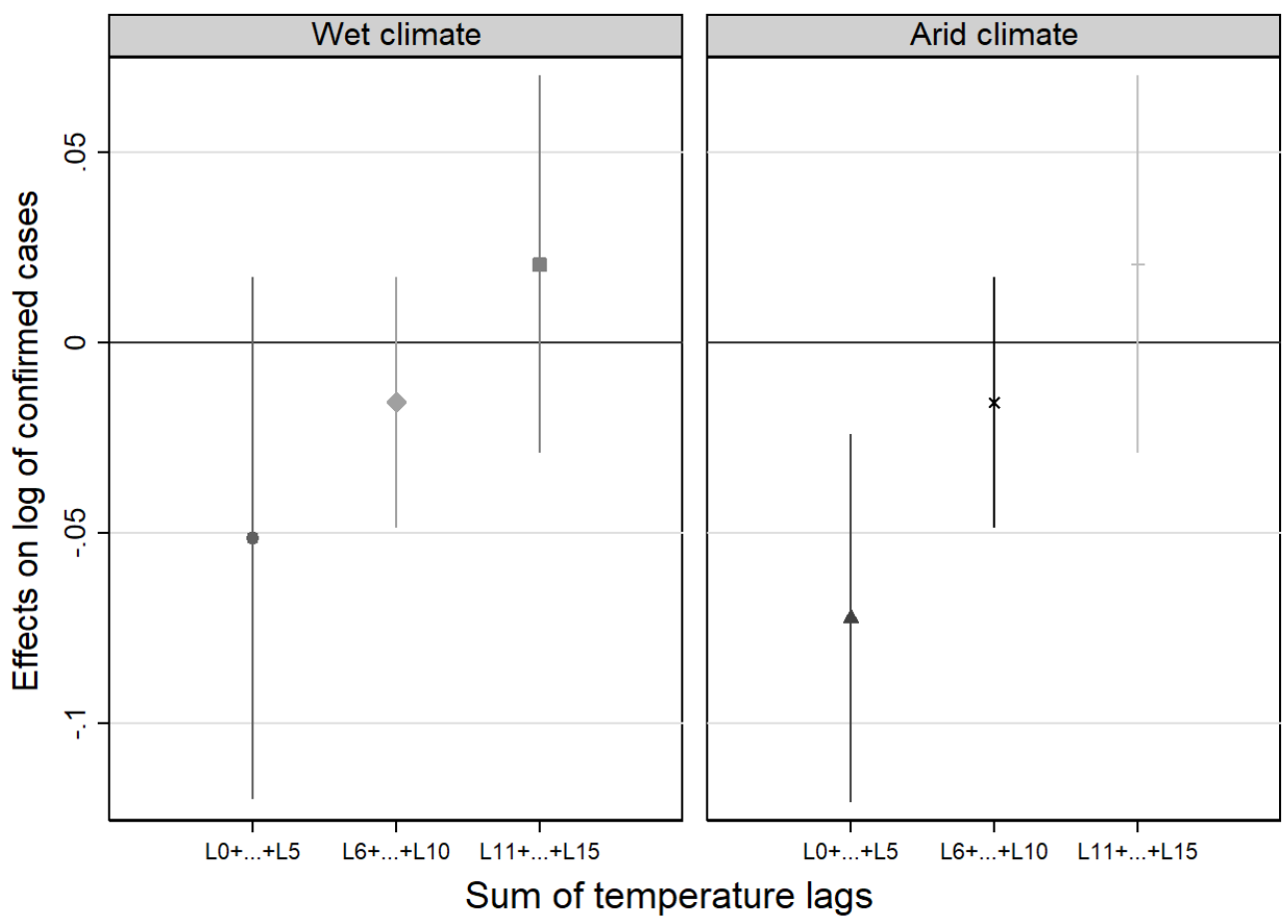

Notes: The figure shows the results of our preferred specification, which includes day and regionmonth fixed effects in the OLS model. We test and present the sum of temperature lags in sets of five (six, for the first 6 lags), along with the $95 \%$ confidence interval, separated in two by the median of the climate precipitation $(2.51 \mathrm{~mm} /$ day $)$. All standard errors are clustered by region/country and all regressions are weighted by the population of that area in 2019. The average number of cases for the "Wet climate" group is 2,472 and 2,208 in the "Arid climate" group. To calculate the number of average cases, we consider only positive values, since the log transformation of the dependent variable excludes days with zero confirmed cases.

The results indicate that temperature plays a more important role in diminishing the virus transmission in arid regions. In these regions, six consecutive 
days with $1^{\circ} \mathrm{C}$ higher temperature are associated with a $0.072\left[C I_{95 \%}\right.$ : $0.024-$ $0.121]$ drop in the transmission. In wet regions, there are no significant effects of temperature in reducing the number of COVID-19 cases.

\subsubsection{Summary of results}

The results of the previous sections are summarized in Table 2.3.2. However, to make results comparable we calculate the previous effects considering all the coefficients in our model, which are fifteen lags plus the contemporaneous effect (sixteen total). We see that the effect of temperature on reducing COVID-19 transmissions is higher than the effects of humidity and precipitation when we consider the total effect calculated by the model. While temperature reduces infections by 0.086 [ $C I_{95 \%}$ : 0.008-0.164], humidity and precipitation do not show significant results in diminishing cases. In other words, it shows that temperature plays a more important role in diminishing transmissions than the effects of humidity and precipitation ${ }^{2.3 .3}$.

Then we tested the effects of temperature for different climates. Again, we use all the sixteen coefficients (fifteen lags plus the contemporaneous effect), so they are readily comparable. Regarding temperature, we compared warm and cold climates. Estimates indicate cold climates benefit more from temperature shocks $0.121\left[C I_{95 \%}: 0.022-0.219\right]$ - than warm climates, whose results are not significant when all the coefficients of the model are considered.

We also compared regions in terms of moist climates (high levels of humidity) and dry climates (low levels of humidity). Only the effects for dry climates are sustained when we use all the sixteen coefficients of the model. Estimates suggest a reduction of 0.096 [CI $\left.I_{95 \%}: 0.002-0.189\right]$ in cases. Results were no significant for the moist climates.

Finally, in terms of wet climates (high levels of precipitation) and arid climates (low levels of precipitation), there were no significant effects of temperature

\footnotetext{
${ }^{2.3 .3}$ Humidity and precipitation are no significant in explaining the virus transmission when we consider all sixteen coefficients in our model.
} 
in wet climates with any number of lags. The model showed significant results, though, for the sum of all the lags in arid climates $-0.114\left[C I_{95 \%}: 0.012-0.216\right]$.

Table 2.3.2 - Summary of results

\begin{tabular}{|c|c|c|c|c|c|}
\hline $\begin{array}{l}\text { Weather } \\
\text { Variable }\end{array}$ & Sample & Coefficient & $\begin{array}{c}\text { [95\% Confidence } \\
\text { Interval] }\end{array}$ & $\begin{array}{c}\text { Estimated } \\
\text { Effect }^{14}\end{array}$ & Condition simulated \\
\hline Humidity & $\begin{array}{c}\text { All } \\
\text { regions }\end{array}$ & - & Not significant & - & $\begin{array}{l}\text { (16 consecutive days } 0.01 \text { p.p } \\
\text { higher) }\end{array}$ \\
\hline Precipitation & $\begin{array}{c}\text { All } \\
\text { regions }\end{array}$ & - & Not significant & - & $\begin{array}{l}\text { (16 consecutive days } 1 \mathrm{~mm} \\
\text { higher) }\end{array}$ \\
\hline \multirow{7}{*}{ Temperature } & $\begin{array}{c}\text { All } \\
\text { Regions }\end{array}$ & 0.086 & {$[0.008-0.164]$} & $8.98 \%$ & $\begin{array}{c}\text { (16 consecutive days } 1^{\circ} \mathrm{C} \\
\text { higher) }\end{array}$ \\
\hline & Warm & - & Not significant & - & $\begin{array}{c}\text { (16 consecutive days } 1^{\circ} \mathrm{C} \\
\text { higher) }\end{array}$ \\
\hline & Cold & 0.121 & {$[0.022-0.219]$} & $12.86 \%$ & $\begin{array}{l}\text { (16 consecutive days } 1^{\circ} \mathrm{C} \\
\text { higher) }\end{array}$ \\
\hline & Moist & - & Not significant & - & $\begin{array}{l}\text { (16 consecutive days } 1^{\circ} \mathrm{C} \\
\text { higher) }\end{array}$ \\
\hline & Dry & 0.096 & {$[0.002-0.189]$} & $10.08 \%$ & $\begin{array}{l}\text { (16 consecutive days } 1^{\circ} \mathrm{C} \\
\text { higher) }\end{array}$ \\
\hline & Wet & - & Not significant & - & $\begin{array}{l}\text { (16 consecutive days } 1^{\circ} \mathrm{C} \\
\text { higher) }\end{array}$ \\
\hline & Arid & 0.114 & {$[0.012-0.216]$} & $12.08 \%$ & $\begin{array}{c}\text { (16 consecutive days } 1^{\circ} \mathrm{C} \\
\text { higher) }\end{array}$ \\
\hline
\end{tabular}

Notes: The table summarizes the effects of weather variables on COVID-19 reduction for all specifications. For each result we specify the condition simulated. We estimate them considering all the coefficients of the model (fifteen lags plus the contemporaneous effect). As the dependent variable of our model is in logs, the exact calculated effect consists in exponentiate the coefficient, subtract one from this number, and multiply by 100 . This gives the percent increase (or decrease) in the response for every one-unit increase in the independent variable. For example, a coefficient 0.038 is transformed in the following way: $(\exp (0.038 \times \delta)-1) \times 100=3.87 \%$. For every $\delta$-unit increase in the independent variable, which is $1^{\circ} \mathrm{C}$ in most of the cases, our dependent variable increases by about $3.87 \%$.

\subsubsection{Robustness checks}

In this section, we perform robustness exercises related to our previous findings. First, we analyze the robustness of our model in terms of the lag choice. We present our preferred specification with 5, 10, 15 and 20. The results are not sensitive to the lag choice of the model. 
We varied the number of lags used in the temperature model (Figure 2.3.5). We test the sum of lags in sets of five, from five to twenty, in four different models: with 5, 10, 15 and 20 lags. Independent of the lag choice, the sets of coefficients present similar levels of significance from the first to the twentieth lag. Significance tests for the sum of the lags in each case indicate that the coefficients' magnitudes are practically the same in all specifications, which shows our model is consistent regarding the lag choice.

Figure 2.3.5 - Impacts of temperature on COVID-19 confirmed cases - 20, 15, 10 and 5 Lags - Jan to Apr 2020
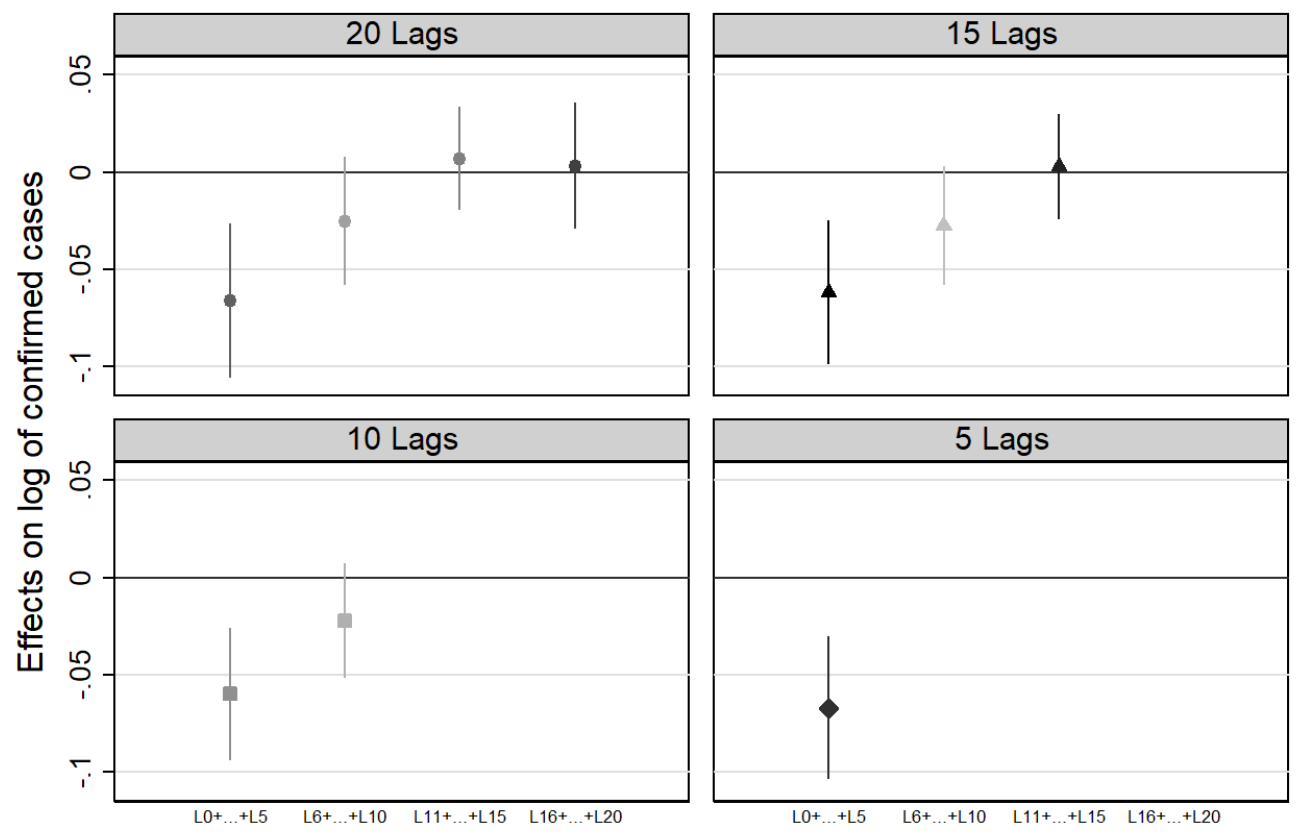

Sum of temperature lags

Notes: The figure shows our main specification, which is a standard ordinary least square regression (OLS) with time and region-month fixed effects, in models with 5, 10, 15 and 20 lags. We test and present the sum of temperature lags in sets of five, along with a 95\% confidence interval. All standard errors are clustered by region/country and all regressions are weighted by the population of that area in 2019.

Second, although our daily data grants great variability to estimate the 
effects of weather on COVID-19 cases, we also know that are reporting problems faced by several countries. Some of them include shortness of testing, spikes in cases after weekends and holidays, and others (The New York Times (2020)). For this reason, we run a robustness test in Table 2.3.3, column (2) where we compare our main result with an alternative version of our dependent variable that calculates the seven-day moving average of confirmed cases. Calculating the moving average smooths our data and eliminates some of the potential problems mentioned above. Results are very similar to our main results, both in terms of magnitude and significance. It is an indicative that the fixed effects in our model (day and region-month) are successfully controlling for potential confounders that otherwise could jeopardize our results.

Then, we run more two robustness exercises to address possible concerns regarding size differences between regions and countries in our sample. In Table 2.3.3, column (3), we use only countries in our regressions to check if our results would be the same using a broader spatial panel unit. Finally, column (4) considers only regions in the regression. The regions we considered are listed in the Table 2.4.4, and belong to the following countries: Canada, China, France, Italy, Netherlands, United Kingdom and United States.

Overall, column (3) presents similar magnitudes to our main results, but no significance, while column (4) is significant in the initial lags, from 1 to 6 , but higher order positive lags diminish the total effects. Considering the substantial drop in the number of observations we incur (from 21 thousand to 9 thousand in one case) to run these alternative exercises, we understand these results reinforce the robustness of our model because they match or resemble our main specification. 
Table 2.3.3 - Impacts of temperature on COVID-19 confirmed cases - Robustness checks, Jan to Apr 2020

\begin{tabular}{lllll} 
& $(1)$ & $(2)$ & $(3)$ & $(4)$ \\
& Main results & Week Mov. Avg. & Countries & Regions \\
\hline Temp & $-0.0224^{* * *}$ & $-0.0258^{* * *}$ & $-0.0317^{*}$ & $-0.0098^{* * *}$ \\
Temp $_{t-1}$ & $-0.0062^{* *}$ & $-0.0075^{* * *}$ & -0.0058 & $-0.0028^{*}$ \\
Temp $_{t-2}$ & $-0.0105^{* * *}$ & $-0.0112^{* * *}$ & -0.0125 & $-0.0041^{* *}$ \\
Temp $_{t-3}$ & $-0.0062^{*}$ & $-0.0090^{* * *}$ & -0.0050 & $-0.0054^{* * *}$ \\
Temp $_{t-4}$ & $-0.0080^{* *}$ & $-0.0076^{* *}$ & -0.0081 & $-0.0066^{* * *}$ \\
Temp $_{t-5}$ & $-0.0085^{* *}$ & $-0.0105^{* * *}$ & -0.0108 & $-0.0084^{* * *}$ \\
Temp $_{t-6}$ & $-0.0109^{* * *}$ & $-0.0111^{* * *}$ & -0.0142 & $-0.0097^{* * *}$ \\
Temp $_{t-7}$ & -0.0031 & -0.0037 & 0.0008 & $-0.0044^{* * *}$ \\
Temp & -0.0062 & -0.0065 & -0.0089 & -0.0024 \\
Temp $_{t-9}$ & -0.0038 & -0.0033 & -0.0016 & -0.0027 \\
Temp $_{t-10}$ & -0.0037 & -0.0019 & -0.0028 & $0.0040^{*}$ \\
Temp $_{t-11}$ & 0.0032 & 0.0037 & 0.0085 & $0.0077^{* * *}$ \\
Temp $_{t-12}$ & 0.0035 & 0.0033 & 0.0066 & $0.0086^{* * *}$ \\
Temp $_{t-13}$ & -0.0000 & -0.0016 & 0.0001 & $0.0036^{*}$ \\
Temp $_{t-14}$ & 0.0038 & 0.0019 & 0.0054 & $0.0048^{* * *}$ \\
Temp $_{t-15}$ & -0.0076 & -0.0055 & -0.0083 & $0.0073^{* *}$ \\
Observations $^{*}$ & 21223 & 21235 & 8734 & 12435 \\
$R^{2}$ & 0.95 & 0.95 & 0.96 & 0.93 \\
$\sum_{t=0}^{15} \hat{\beta}_{l}$ & $-0.09^{* *}$ & $-0.10^{* *}$ & -0.09 & -0.02 \\
Prec. Control & Yes & Yes & Yes & Yes \\
\hline
\end{tabular}

Notes: The table compares our main specification (column 1) with another version of our dependent variable that uses the logarithm of weekly moving average cases, instead of the log of daily cases (column 2). We include a specification that uses only countries in the regression (column 3), and a final one with only regions (column 4). All regressions include day and region-month fixed effects, as well as precipitation controls ("Prec. Control") and all standard errors are clustered by region/country. All regressions are weighted by the population of that area in 2019. The table also shows the number of observations used in each model, along with the $\mathrm{R}$ squared value. Finally, we also present the significance test for the sum of the 15 lags $\left(\sum_{t=0}^{15} \hat{\beta}_{l}\right) .{ }^{*} \mathrm{p}<0.10,{ }^{* *} \mathrm{p}<0.05$, $* * * \mathrm{p}<0.01$ 


\subsection{Discussion and policy implications}

The weather may be a key factor in mitigating the SARS-CoV-2 virus propagation, but there is still uncertainty regarding the strength of this effect. We contribute to this literature by exploring the weather exogeneity to estimate a global daily panel model using cross-regional data with time and region fixed effects to test if weather variables somehow influence the propagation of COVID-19 cases.

We find evidence that an increase in temperature of $1^{\circ} \mathrm{C}$ reduces the virus transmission by $8.98 \%$, on average. We also assess the heterogeneity of the effects by different climates, to understand if the seasonal change might affect the transmission of the disease. We find that the effect of temperature is stronger in cold climates, reaching $12.86 \%$, in arid climates, reducing cases up to $12.08 \%$, and in dry climates, with a decline of $10.08 \%$ in cases.

Despite of the mentioned significant weather effects on diminishing the virus transmission, we argue they are still very small because relevant reductions in transmission would require several days with favorable weather conditions.

It is also worth noting that our data spams only one season, from January to April, 2020. This can somehow impact results since it was mostly winter in the Northern hemisphere and summer in the Southern hemisphere in this period. Future works can certainly benefit from longer timespan datasets that allow controlling for more seasons in both hemispheres.

Our findings reinforce the ideas postulated by some works that argue that weather will not necessarily reduce the number of COVID-19 cases by itself, and that the only sure way to reduce transmission is by implementing extensive public health interventions (Ferguson et al. (2020); Jüni et al. (2020); Lipsitch (2020); Luo et al. (2020); The Lancet (2020)).

As an anecdotal example of this fact, we can cite the city of Manaus, Brazil, with population of more than 3 million located at latitude -3.10 and longitude -60.02, in the heart of the Amazon Rainforest, a tropical region known for its warm and wet climate. These supposedly favorable weather conditions did not stop the virus from causing a total breakdown of the local health and funeral services. Many 
factors can jointly explain the chaos affecting the city. Examples are an underfunded and understaffed health service before the SARS-CoV-2 outbreak, corruption, and lack of effective social distancing and protection measures, among others (Phillips e Maisonnave (2020)).

More research is needed to fully understand the effects of weather on COVID19 transmission. However, this early evidence suggests that its effects are small in preventing the spread of the disease by itself (Lipsitch (2020)). Many other aspects, such as social distancing, self-isolation, school closure, and the end of public events may be more relevant than the weather in stopping the virus (Flaxman et al. (2020)). 


\section{Appendix B}

This appendix is divided in four subsections. In section B.1., we present further descriptive statistics of the COVID-19 and climate variables. In section B.2., we show the correlation between climate variables and COVID-19 cases on April 23, 2020 to test possible effects of weather on the spread of the disease, along with considerations regarding extreme (high and low) climate temperatures. In section B.3., we analyze the results of our main specification for the humidity and precipitation variables. Then, in section B.4., we show a list of the provinces, states and countries considered in our analysis.

\section{Appendix B.1. Further descriptive statistics}

This section presents further descriptive statistics of the COVID-19 outbreak, as well as the climate variables used in our heterogeneity exercises. The Figure 2.4.1 shows the evolution of the number of COVID-19 cases from January 22, 2020 to April 23, 2020. We see how the outbreak started later in countries like Brazil, Iran, Italy and Switzerland, but increased rapidly in almost all of them. Appendix Figure 2.4.2 shows the number of cases in countries with more than 50,000 cases by April 23, 2020. The most affected countries by that time were United States, Spain and Italy. Next, Appendix Figure 2.4.3 presents daily average growth rates of cases when cases surpass 1,000 . We see that for almost 20 countries, cases were increasing daily at a rate of more than $10 \%$, on average. The United States (17.2\%), Turkey (15.8\%) and Russia (15.5) presented the highest rates until April 23, 2020. 
Figure 2.4.1 - Confirmed cases of COVID-19 for selected countries, Jan-Apr 2020
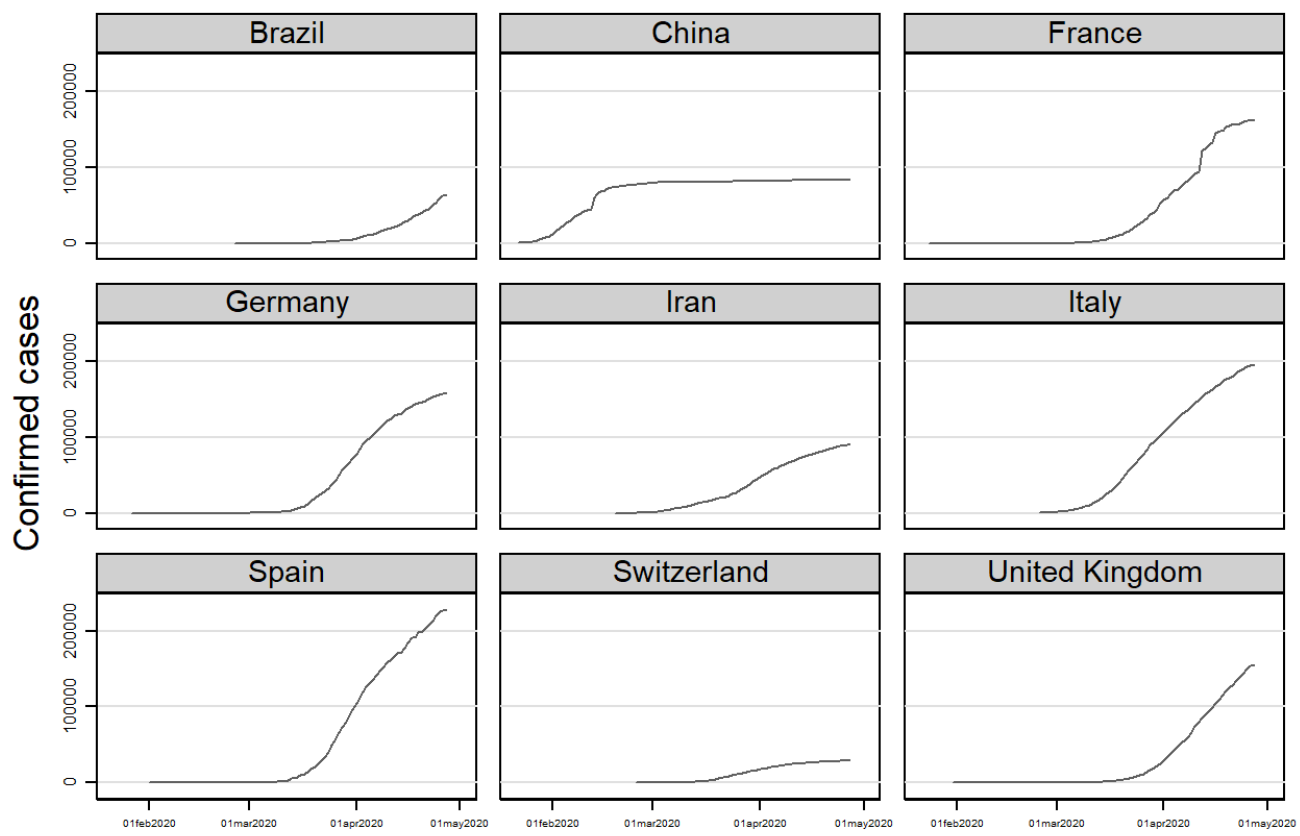

Time in days

Notes: The figure shows the evolution of confirmed COVID-19 cases in selected countries from January 22, 2020 until April 23, 2020. 
Figure 2.4.2 - Countries with more than 50,000 confirmed cases of COVID-19 by April 23, 2020

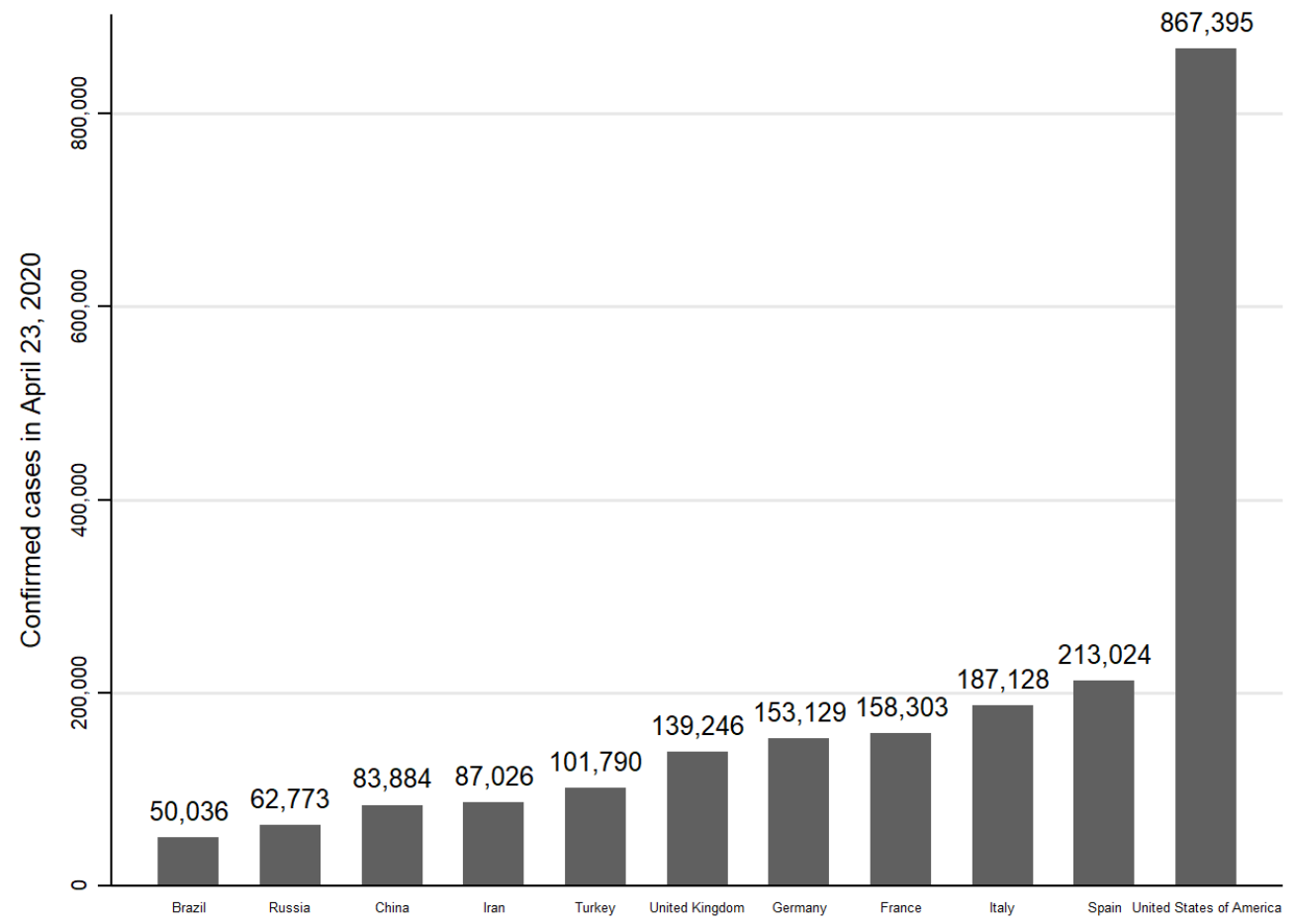

Notes: The figure shows the number of confirmed COVID-19 cases for countries that presented more than 50,000 cases by April 23, 2020. 
Figure 2.4.3 - Confirmed cases - Daily average growth rates above 10\%

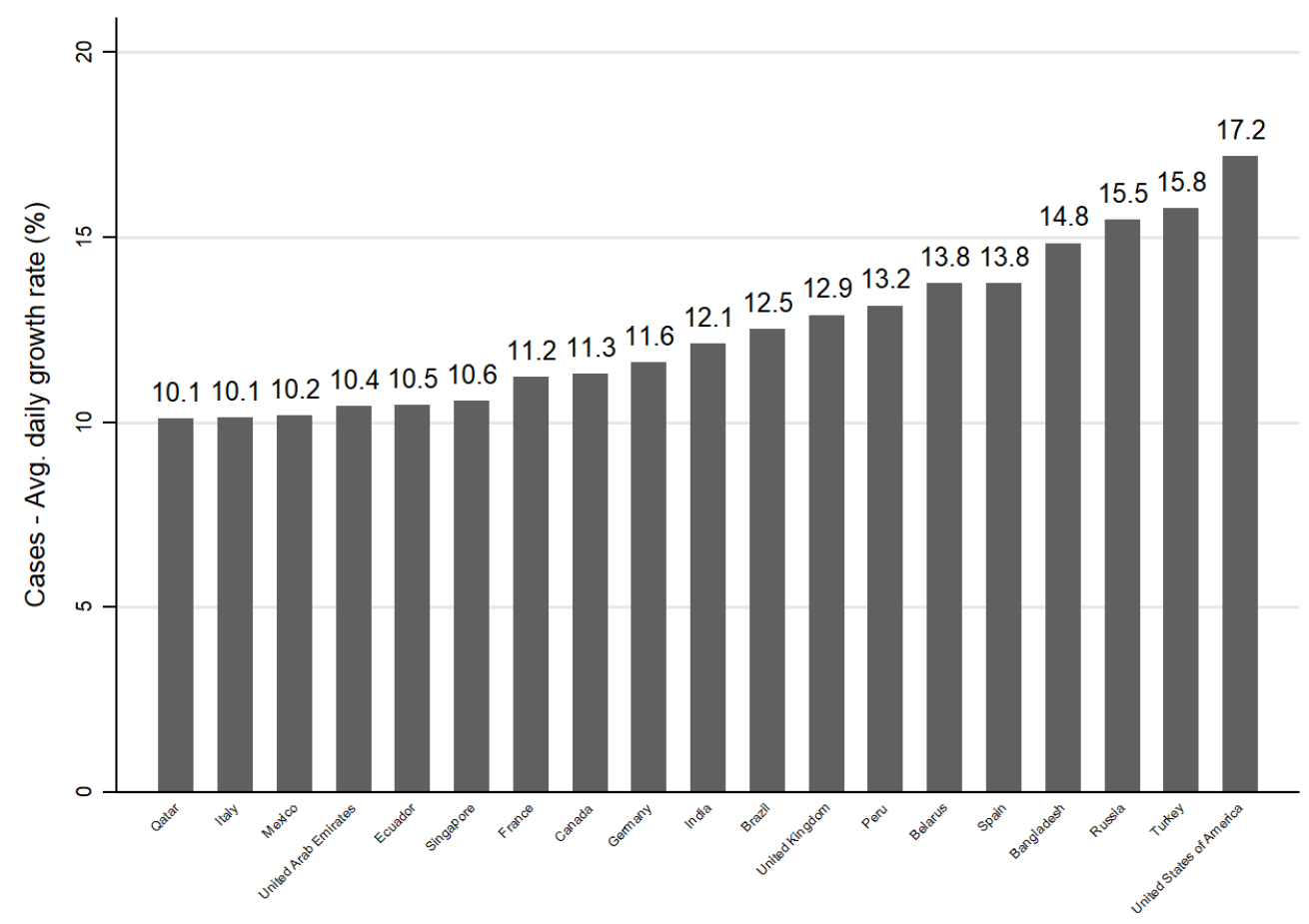

Notes: The figure shows daily average growth rates of cases for countries whose average rate is higher than $10 \%$. Growth rates are calculated when cases surpass 1,000.

The Table 2.4.1 provide descriptive statistics of the climate variables. The overall statistics are calculated for the full sample, the between statistics relate to the countries and regions of our database and the within statistics are calculated throughout time for the same units. One should notice that the climate variables have zero within variation. This result is due to the construction of these variables, that are calculated as monthly averages of the weather variables between 1990 to 2019 (30 years), considering all 12 months of each year. They are used in our heterogeneity exercises to separate our sample in half by their medians, that we describe in details throughout the text. 
Table 2.4.1 - Summary of results

\begin{tabular}{|c|c|c|c|c|c|}
\hline Variable & Mean & Std.Dev. & Min & Max & Observations \\
\hline \multicolumn{6}{|c|}{ Temperature, climate $\left({ }^{\circ} \mathrm{C}\right)$} \\
\hline Overall & 15.17 & 8.25 & -22.18 & 29.43 & $N=38688$ \\
\hline Between & & 8.26 & -22.18 & 29.43 & $n=416$ \\
\hline Within & & 0 & 15.169 & 15.169 & $\mathrm{~T}=93$ \\
\hline \multicolumn{6}{|c|}{ Humidity, climate (\%) } \\
\hline Overall & 1.01 & 0.44 & 0.14 & 1.98 & $N=38688$ \\
\hline Between & & 0.44 & 0.14 & 1.98 & $n=416$ \\
\hline Within & & 0 & 1.01 & 1.01 & $\mathrm{~T}=93$ \\
\hline \multicolumn{6}{|c|}{ Precipitation, climate (mm/day) } \\
\hline Overall & 2.93 & 1.90 & 0.001 & 12.08 & $N=38688$ \\
\hline Between & & 1.90 & 0.001 & 12.08 & $\mathrm{n}=416$ \\
\hline Within & & 0 & 2.93 & 2.93 & $T=93$ \\
\hline
\end{tabular}

Notes: The table shows summary statistics of all climate variables of our sample of 416 countries or regions. The temperature variables are presented in ${ }^{\circ} \mathrm{C}$, while the specific humidity variables are presented in $\%$ and the precipitation variables in $\mathrm{mm} /$ day. Climate variables are calculated as monthly averages of weather variables between 1990 to 2019 (30 years).

\section{Appendix B.2. Correlation between climate and COVID-19}

To evaluate the possible correlation between weather variables and confirmed cases of COVID-19, we regress the total number of cases on April 23, 2020 with climate temperature, humidity and precipitation. The results, depicted in Figures 2.4.4, 2.4.5 and 2.4.6, indicate that the number of cases is negatively correlated with temperature and humidity, but not with precipitation. This is in line with recent observations of faster spread of the virus in cold and dry environments (Araujo e Naimi (2020); Confalonieri et al. (2020); Wang et al. (2020)). The effect of weather on virus transmission is probably linked to the ability of the virus to survive in external environments. The SARS-CoV-1 virus, for example, rapidly loses its physical stability and literally breaks down when temperature reaches $38^{\circ} \mathrm{C}$ and relative humidity is above $95 \%$ (Chan et al., 2011). We also explore this fact in the Table 2.4.2 to test the levels of temperatures that are detrimental to the physical stability of the pathogen. In this sense, we have performed additional 
exercises by separating the sample into regions of different long-term climates. Results show that effects of increasing temperatures are larger in historically cold environments (below $15^{\circ} \mathrm{C}, 13^{\circ} \mathrm{C}$ and $11^{\circ} \mathrm{C}$ ), but have almost no effects in already warm environments (above $15^{\circ} \mathrm{C}, 17^{\circ} \mathrm{C}$ and $19^{\circ} \mathrm{C}$ ).

Figure 2.4.4 - Correlation between total confirmed COVID-19 cases on April 23, 2020 and climate temperature, Avg. Jan-Apr from 1990 to 2019

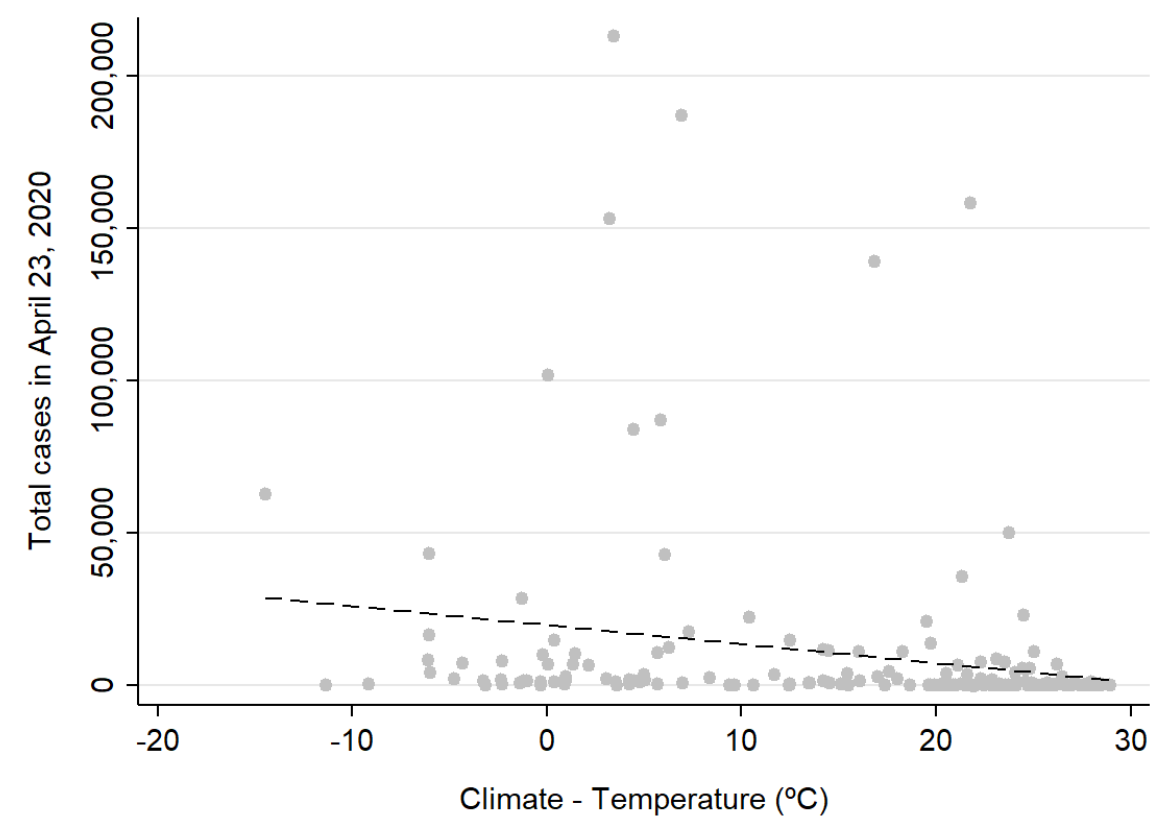

Notes: The figure shows the correlation between the cumulative number of COVID-19 cases on April 23, 2020 and climate temperature in ${ }^{\circ} \mathrm{C}$. There is a negative correlation between temperature and total cases. The United States is omitted from the sample for being an outlier, but the conclusions do not change when it is included. The correlation is also negative if we use the in-sample temperature from January 22, 2020 to April 23, 2020. 
Figure 2.4.5 - Correlation between total confirmed COVID-19 cases on April 23, 2020 and climate specific humidity, Avg. Jan-Apr from 1990 to 2019

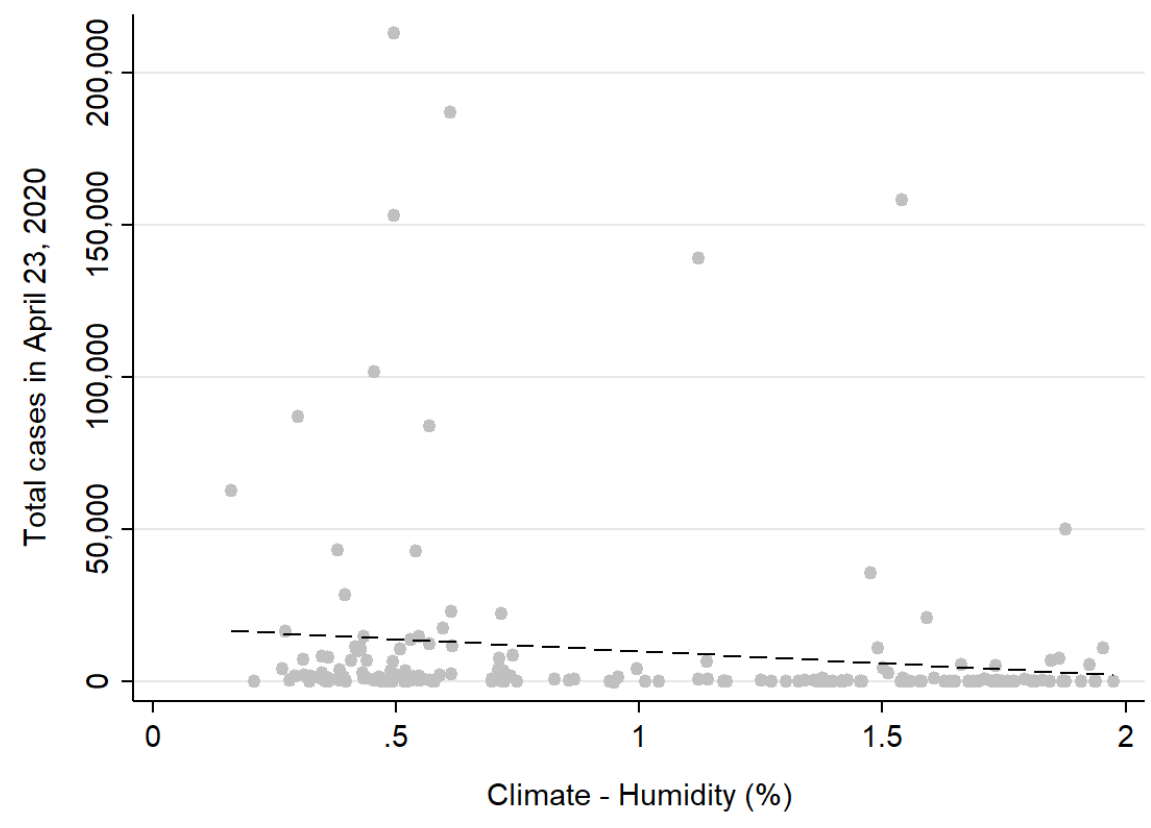

Notes: The figure shows the correlation between the cumulative number of COVID-19 cases on April 23, 2020 and climate specific humidity in \%. There is a negative correlation between humidity and total cases. The United States is omitted from the sample for being an outlier, but the conclusions do not change when it is included. The correlation is also negative if we use the in-sample humidity from January 22, 2020 to April 23, 2020. 
Figure 2.4.6 - Correlation between total confirmed COVID-19 cases on April 23, 2020 and climate precipitation, Avg. Jan-Apr from 1990 to 2019

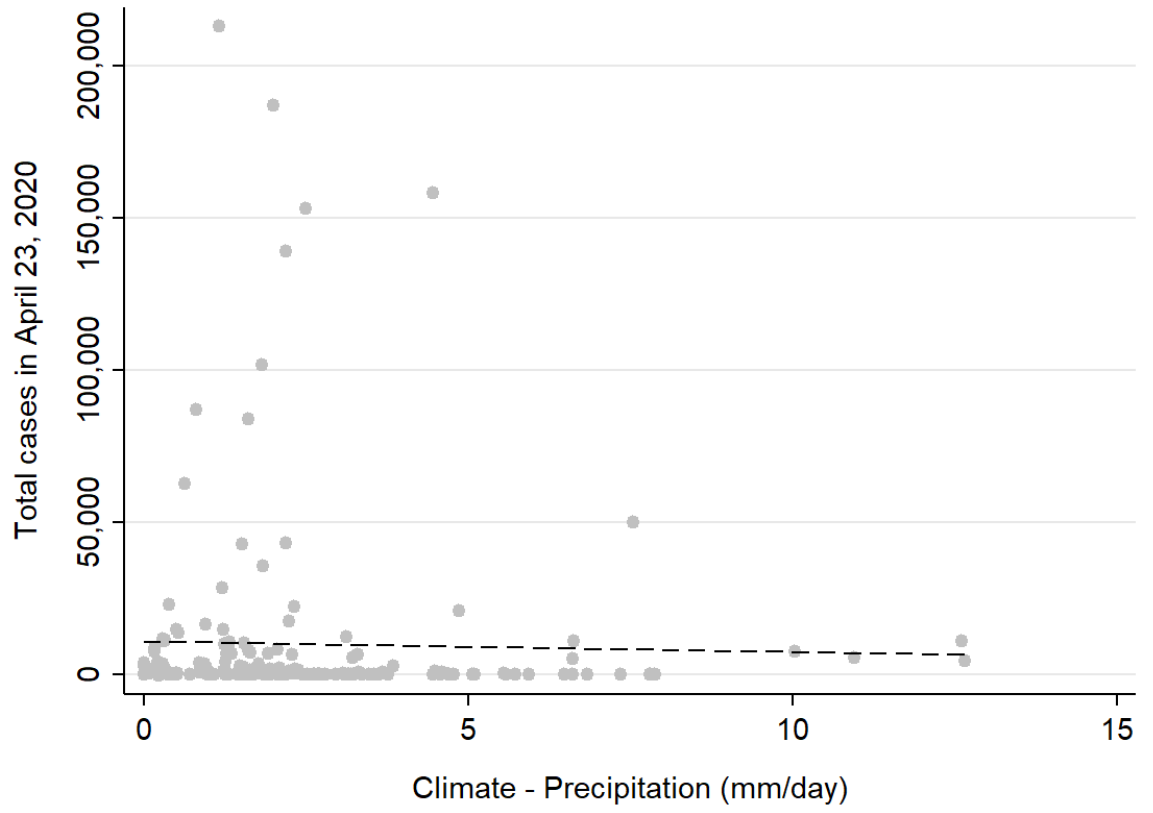

Notes: The figure shows the correlation between the cumulative number of COVID-19 cases on April 23, 2020 and climate precipitation in $\mathrm{mm} /$ day. There is no apparent correlation between precipitation and total cases. The United States is omitted from the sample for being an outlier, but the conclusions do not change when it is included. The correlation is also nonexistent if we use the in-sample precipitation from January 22, 2020 to April 23, 2020. 
Table 2.4.2 - Impacts of different levels of temperature on COVID-19 confirmed cases - Jan to Apr, 2020

\begin{tabular}{lccccccc} 
& Main & $<11^{\circ} \mathrm{C}$ & $<13^{\circ} \mathrm{C}$ & $<15^{\circ} \mathrm{C}$ & $>15^{\circ} \mathrm{C}$ & $>17^{\circ} \mathrm{C}$ & $>19^{\circ} \mathrm{C}$ \\
\hline Temp $_{t}$ & $-0.0117^{* * *}$ & $-0.0119^{* * *}$ & $-0.0115^{* * *}$ & $-0.0118^{* * *}$ & $-0.0154^{* * *}$ & $-0.0126^{* *}$ & -0.0097 \\
Temp $_{t-1}$ & $-0.0034^{* * *}$ & $-0.0049^{* *}$ & $-0.0039^{* *}$ & $-0.0037^{* *}$ & -0.0014 & -0.0014 & -0.0028 \\
Temp $_{t-2}$ & $-0.0061^{* * *}$ & $-0.0058^{* * *}$ & $-0.0055^{* * *}$ & $-0.0060^{* * *}$ & $-0.0092^{* * *}$ & $-0.0091^{* *}$ & $-0.0088^{* *}$ \\
Temp $_{t-3}$ & $-0.0057^{* * *}$ & $-0.0045^{*}$ & $-0.0042^{*}$ & $-0.0056^{* * *}$ & $-0.0048^{* *}$ & -0.0002 & 0.002 \\
Temp $_{t-4}$ & $-0.0041^{* * *}$ & $-0.0046^{* *}$ & $-0.0043^{* *}$ & $-0.0045^{* *}$ & -0.0038 & -0.0018 & 0.0017 \\
Temp $_{t-5}$ & $-0.0058^{* * *}$ & -0.0036 & -0.0035 & $-0.0059^{* * *}$ & $-0.0057^{*}$ & -0.0025 & -0.0002 \\
Temp $_{t-6}$ & $-0.0056^{* * *}$ & $-0.0077^{* * *}$ & $-0.0071^{* * *}$ & $-0.0078^{* * *}$ & -0.0011 & 0.0006 & 0.0016 \\
Temp $_{t-7}$ & -0.001 & $-0.0037^{*}$ & $-0.0035^{*}$ & -0.0027 & 0.0027 & $0.0044^{*}$ & 0.0033 \\
Temp $_{t-8}$ & -0.0008 & -0.003 & -0.0023 & -0.0024 & 0.0017 & 0.0008 & 0.003 \\
Temp $_{t-9}$ & $-0.0024^{*}$ & -0.0035 & $-0.0038^{*}$ & $-0.0032^{*}$ & -0.0014 & 0.0042 & $0.0082^{* *}$ \\
Temp $_{t-10}$ & 0.0024 & -0.0012 & -0.0005 & 0.0007 & $0.0068^{* * *}$ & $0.0071^{* *}$ & 0.0075 \\
Temp $_{t-11}$ & $0.0051^{* * *}$ & 0.0019 & 0.0019 & 0.0034 & $0.0064^{* * *}$ & $0.0067^{* *}$ & 0.0052 \\
Temp $_{t-12}$ & $0.0053^{* * *}$ & 0.0026 & 0.0026 & $0.0051^{* * *}$ & $0.0051^{* *}$ & 0.0037 & 0.0045 \\
Temp $_{t-13}$ & -0.0005 & -0.0007 & -0.0009 & -0.0029 & 0.0029 & $0.0058^{* *}$ & 0.0043 \\
Temp $_{t-14}$ & 0.0018 & -0.0008 & -0.0007 & 0.0005 & 0.0034 & -0.0006 & -0.001 \\
Temp $_{t-15}$ & $-0.0055^{*}$ & $-0.0077^{*}$ & $-0.0067^{*}$ & $-0.0092^{* *}$ & -0.0017 & 0.0012 & -0.0053 \\
\hline Observations $^{2}$ & 21510 & 8096 & 9482 & 10695 & 10815 & 8105 & 6035 \\
$R^{2}$ & 0.95 & 0.95 & 0.95 & 0.94 & 0.95 & 0.95 & 0.95 \\
L $_{t=0}^{15} \hat{\beta}_{l}$ & $-0.04^{* *}$ & $-0.06^{* *}$ & $-0.05^{* *}$ & $-0.06^{* *}$ & -0.02 & 0.01 & 0.01 \\
\hline
\end{tabular}

Notes: The table compares our main specification with regressions that use different levels of the long run temperature (climate). Regressions include time and region-month fixed effects, as well as precipitation controls ("Prec. Control") and all standard errors are clustered by region/country. All regressions are weighted by the population of that area in 2019. The table also shows the number of observations used in each model, along with the $\mathrm{R}$ squared value. Finally, we also present the significance test for the sum of the 15 lags $\left(\sum_{t=0}^{15} \hat{\beta}_{l}\right){ }^{*} \mathrm{p}<0.10,{ }^{* *} \mathrm{p}<0.05,{ }^{* * *} \mathrm{p}$ $<0.01$

\section{Appendix B.3. Main specification results for humidity and precipitation}

In this section we show that humidity and precipitation are significant in explaining the reduction in the virus transmission. The results, however, are much weaker compared to the effects of temperature.

Figure 2.4.7 present the results of our empirical exercise for humidity. All the specifications presented similar patterns in terms of magnitude and significance of the sum of the coefficients. Considering our preferred specification and testing intervals of five lags, we found that only lags one to six show significant effects on 
COVID-19 reduction. So, six consecutive days with humidity 0.01 percentage point higher are associated with a 0.004 [CI $\left.I_{95 \%}: 0.001-0.007\right]$ decrease in transmissions.

We also find evidence that precipitation is associated with COVID-19 transmissions, but only slightly (Figure 2.4.8). In all specifications, including our preferred one, the sum of the 15 lags of the variable is not significant to explain changes in confirmed cases. However, lags one to five significantly reduce the virus transmission, but at a much smaller scale than temperature. The contemporaneous effect, plus five consecutive days with precipitation $1 \mathrm{~mm}$ higher, is expected to reduce transmission by around $0.013\left[C I_{95 \%}: 0.001-0.026\right]$.

Figure 2.4.7 - Specific humidity effects on log of confirmed cases in sets of three lags, Jan-Apr 2020

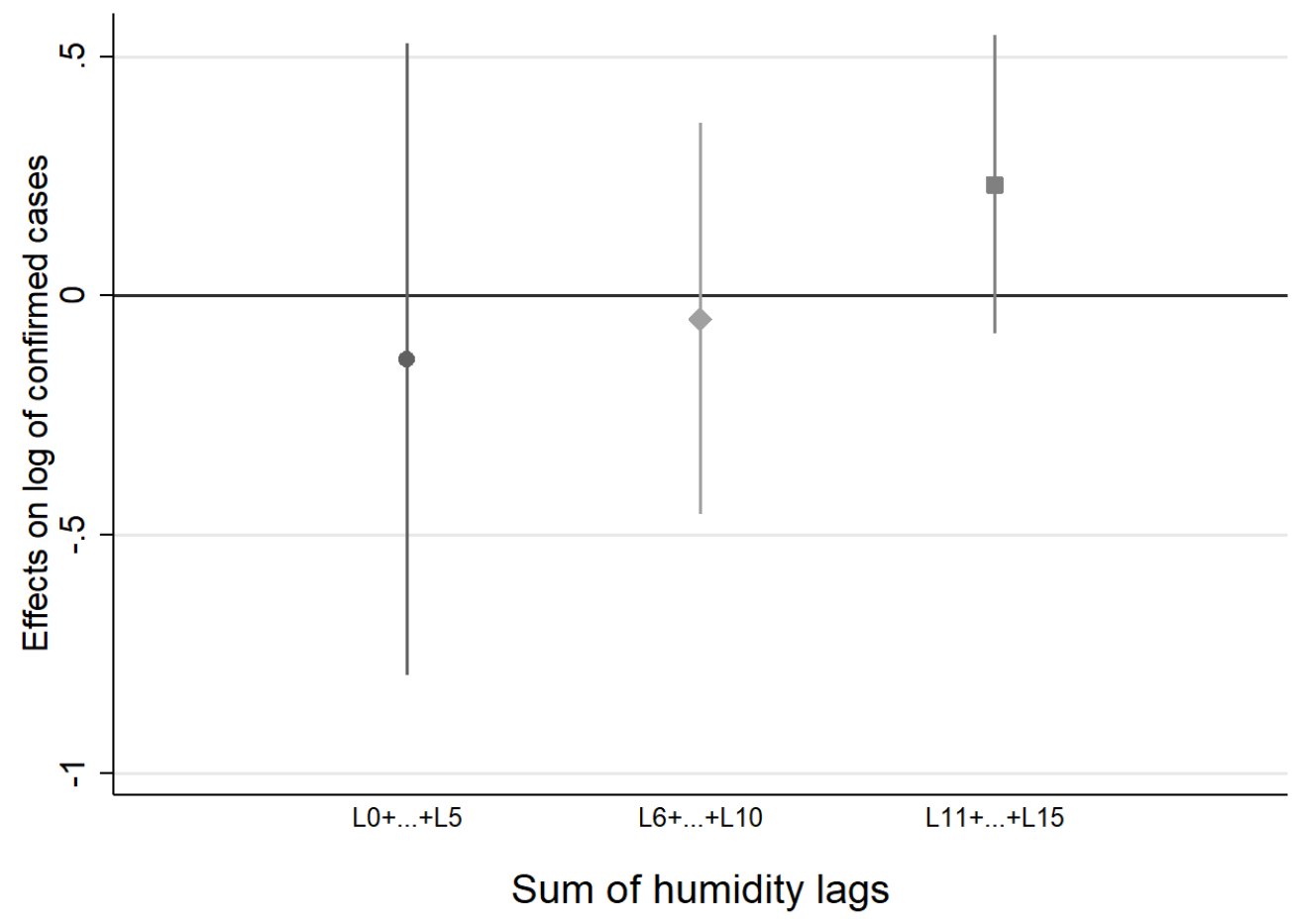

Notes: The figure shows the results of our preferred specification, which includes time and region fixed effects in the OLS model. We test and present the sum of humidity lags in sets of five (six, for the first 6 lags), along with a 95\% confidence interval. All standard errors are clustered by region/country and all regressions are weighted by the population of that area in 2019 . 
Figure 2.4.8 - Precipitation effects on log of confirmed cases in sets of three lags, Jan-Apr 2020

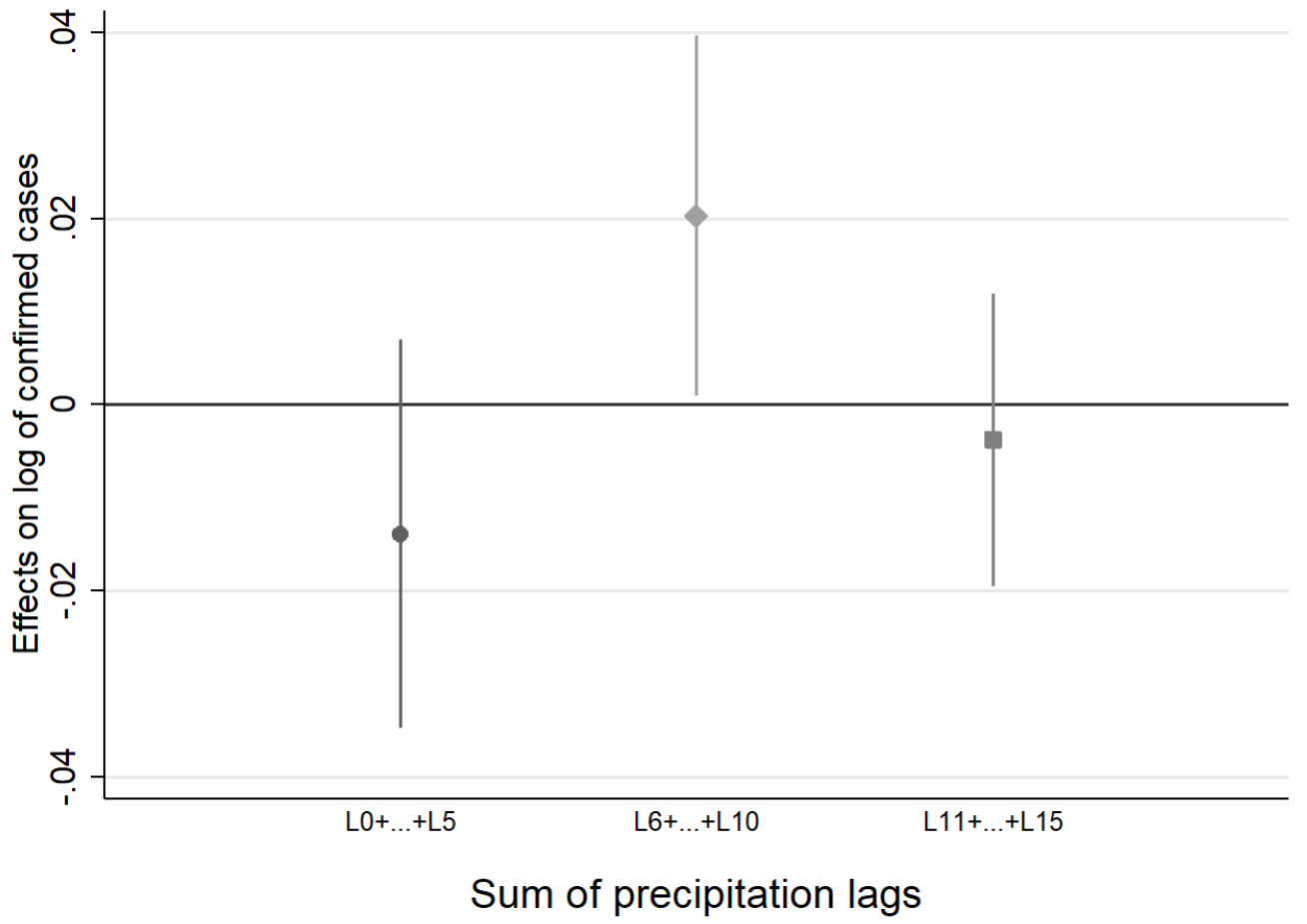

Notes: The figure shows the results of preferred specification, which includes time and region fixed effects in the OLS model. We test and present the sum of precipitation lags in sets of five (six, for the first 6 lags), along with a 95\% confidence interval. All standard errors are clustered by region/country and all regressions are weighted by the population of that area in 2019 . 


\section{Appendix B.4. List of countries, provinces and states used as panel units}

Table 2.4.3 - List of countries

\begin{tabular}{|c|c|c|c|}
\hline Countries & Countries & Countries & Countries \\
\hline Afghanistan & Dominica & Lesotho & Saint Vincent and the Grenadines \\
\hline Albania & Dominican Republic & Liberia & San Marino \\
\hline Algeria & Ecuador & Libya & Sao Tome and Principe \\
\hline Andorra & Egypt & Liechtenstein & Saudi Arabia \\
\hline Angola & El Salvador & Lithuania & Senegal \\
\hline Antigua and Barbuda & Equatorial Guinea & Luxembourg & Serbia \\
\hline Argentina & Eritrea & Madagascar & Seychelles \\
\hline Armenia & Estonia & Malawi & Sierra Leone \\
\hline Australia & Eswatini & Malaysia & Singapore \\
\hline Austria & Ethiopia & Maldives & Slovakia \\
\hline Azerbaijan & Fiji & Mali & Slovenia \\
\hline Bahamas & Finland & Malta & Somalia \\
\hline Bahrain & France & Mauritania & South Africa \\
\hline Bangladesh & Gabon & Mauritius & South Korea \\
\hline Barbados & Gambia & Mexico & South Sudan \\
\hline Belarus & Georgia & Moldova & Spain \\
\hline Belgium & Germany & Monaco & Sri Lanka \\
\hline Belize & Ghana & Mongolia & Sudan \\
\hline Benin & Greece & Montenegro & Suriname \\
\hline Bhutan & Grenada & Morocco & Sweden \\
\hline Bolivia & Guatemala & Mozambique & Switzerland \\
\hline Bosnia and Herzegovina & Guinea & Myanmar & Syria \\
\hline Botswana & Guinea-Bissau & Namibia & Taiwan \\
\hline Brazil & Guyana & Nepal & Tajikistan \\
\hline Brunei & Haiti & Netherlands & Tanzania \\
\hline Bulgaria & Holy See & New Zealand & Thailand \\
\hline Burkina Faso & Honduras & Nicaragua & Timor-Leste \\
\hline Burundi & Hungary & Niger & Togo \\
\hline Cabo Verde & Iceland & Nigeria & Trinidad and Tobago \\
\hline Cambodia & India & North Macedonia & Tunisia \\
\hline Cameroon & Indonesia & Norway & Turkey \\
\hline Canada & Iran & Oman & Uganda \\
\hline Central African Republic & Iraq & Pakistan & Ukraine \\
\hline Chad & Ireland & Panama & United Arab Emirates \\
\hline Chile & Israel & Papua New Guinea & United Kingdom \\
\hline China & Italy & Paraguay & United States \\
\hline Colombia & Jamaica & Peru & Uruguay \\
\hline Comoros & Japan & Philippines & Uzbekistan \\
\hline Costa Rica & Jordan & Poland & Venezuela \\
\hline Croatia & Kazakhstan & Portugal & Vietnam \\
\hline Cuba & Kenya & Qatar & West Bank and Gaza \\
\hline Cyprus & Kosovo & Republic of the Congo & Western Sahara \\
\hline Czechia & Kuwait & Romania & Yemen \\
\hline Côte d'Ivoire & Kyrgyzstan & Russia & Zambia \\
\hline Democratic Rep. of the Congo & Laos & Rwanda & Zimbabwe \\
\hline Denmark & Latvia & Saint Kitts and Nevis & \\
\hline Djibouti & Lebanon & Saint Lucia & \\
\hline
\end{tabular}

Notes: The table shows the countries used as panel units in this work. Source: COVID-19 Dashboard by CSSE at Johns Hopkins University. 
Table 2.4.4 - List of provinces/states considered by country

\begin{tabular}{|c|c|}
\hline Country & Province/State \\
\hline Canada & $\begin{array}{l}\text { Alberta; British Columbia; Diamond Princess; Manitoba; } \\
\text { New Brunswick; Newfoundland and Labrador; } \\
\text { Northwest Territories; Nova Scotia; Ontario; } \\
\text { Prince Edward Island; Quebec; Saskatchewan; Yukon }\end{array}$ \\
\hline China & $\begin{array}{l}\text { Anhui; Beijing; Chongqing; Fujian; Gansu; Guangdong; } \\
\text { Guangxi; Guizhou; Hainan; Hebei; Heilongjiang; Henan; } \\
\text { Hong Kong; Hubei; Hunan; Inner Mongolia; Jiangsu; Jiangxi; } \\
\text { Jilin; Liaoning; Macau; Ningxia; Qinghai; Shaanxi; } \\
\text { Shandong; Shanghai; Shanxi; Sichuan; Tianjin; } \\
\text { Tibet; Xinjiang; Yunnan; Zhejiang }\end{array}$ \\
\hline France & $\begin{array}{c}\text { French Guiana; French Polynesia; Guadeloupe; Martinique; } \\
\text { Mayotte; New Caledonia; Reunion; Saint Barthelemy; } \\
\text { Saint Pierre and Miquelon; St Martin }\end{array}$ \\
\hline Italy & $\begin{array}{l}\text { Agrigento; Alessandria; Ancona; Aosta; Arezzo; Ascoli Piceno; } \\
\text { Asti; Avellino; Bari; Barletta-Andria-Trani; } \\
\text { Belluno; Benevento; Bergamo; Biella; Bologna; Bolzano; } \\
\text { Brescia; Brindisi; Cagliari; Caltanissetta; Campobasso; } \\
\text { Caserta; Catania; Catanzaro; Chieti; Como; Cosenza; } \\
\text { Cremona; Crotone; Cuneo; Enna; Fermo; Ferrara; Firenze; } \\
\text { Foggia; Frosinone; Genova; Gorizia; Grosseto; Imperia; } \\
\text { Isernia; L'Aquila; La Spezia; Latina; Lecce; Lecco; Livorno; } \\
\text { Lodi; Lucca; Macerata; Mantova; Massa Carrara; Matera; } \\
\text { Messina; Milano; Modena; Monza e della Brianza; Napoli; } \\
\text { Novara; Nuoro; Oristano; Padova; Palermo; Parma; Pavia; } \\
\text { Perugia; Pesaro e Urbino; Pescara; Piacenza; Pisa; Pistoia; } \\
\text { Pordenone; Potenza; Prato; Ragusa; Ravenna; Reggio di Calabria; } \\
\text { Reggio nell'Emilia; Rieti; Rimini; Roma; Rovigo; } \\
\text { Salerno; Sassari; Savona; Siena; Siracusa; Sondrio; } \\
\text { Sud Sardegna; Taranto; Teramo; Terni; Torino; Trapani; Trento; } \\
\text { Treviso; Trieste; Udine; Varese; Venezia; Verbano-Cusio-Ossola; } \\
\text { Vercelli; Verona; Vibo Valentia; Vicenza; Viterbo }\end{array}$ \\
\hline Netherlands & $\begin{array}{l}\text { Aruba; Bonaire, Sint Eustatius and Saba; } \\
\text { Curacao; Sint Maarten }\end{array}$ \\
\hline United Kingdom & $\begin{array}{c}\text { Anguilla; Bermuda; British Virgin Islands; } \\
\text { Cayman Islands; Channel Islands; Falkland Islands (Malvinas); } \\
\text { Gibraltar; Isle of Man; Montserrat; Turks and Caicos Islands }\end{array}$ \\
\hline United States & $\begin{array}{c}\text { Alabama; Alaska; Arizona; Arkansas; California; } \\
\text { Colorado; Connecticut; Delaware; District of Columbia; } \\
\text { Florida; Georgia; Hawaii; Idaho; Illinois; Indiana; Iowa; Kansas; } \\
\text { Kentucky; Louisiana; Maine; Maryland; Massachusetts; } \\
\text { Michigan; Minnesota; Mississippi; Missouri; Montana; } \\
\text { Nebraska; Nevada; New Hampshire; New Jersey; } \\
\text { New Mexico; New York; North Carolina; North Dakota; Ohio; } \\
\text { Oklahoma; Oregon; Pennsylvania; Rhode Island; } \\
\text { South Carolina; South Dakota; Tennessee; Texas; Utah; } \\
\text { Vermont; Virginia; Washington; West Virginia; Wisconsin; Wyoming }\end{array}$ \\
\hline
\end{tabular}

Notes: The table shows the provinces or states used as panel units in this work. Source: COVID-19 Dashboard by CSSE at Johns Hopkins University. 



\title{
3 Weather variations and impacts on mortality in Brazil
}

\author{
With Paula Pereda
}

\subsection{Introduction}

For centuries, humanity has been wondering if and how climatic conditions - such as temperature, rainfall and violent storms - shape society and economic outcomes with these questions dating back to the 14th century (Dell, Jones e Olken (2014)). With the recent accumulation of greenhouse gases in a short period of geological time and possible threats to the climate stability of the planet, social sciences have reinforced their interest in understanding the effects of climate change, but there are still many gaps that need to be filled in order to improve economic models to incorporate these features, specially when it comes human health (Barreca et al. (2016), Deschenes (2014)).

Evidences of extreme temperatures impacting mortality rates are well consolidated in the literature for the United States. Estimates suggest that each additional day of temperatures exceeding $32^{\circ} \mathrm{C}$ increase mortality rates by $0.1-0.2 \%$ relative to days with moderate heat. Extreme cold temperatures was also found to be significant in increasing mortality and specific age groups such as elderly and infants are at higher risk (Barreca (2012), Deschenes e Greenstone (2011), Curriero et al. (2002)). An emerging branch of this literature started to explore whether populations in different stages of development are equally affected by weather variations (Geruso e Spears (2018)). Burgess et al. (2017) found that hot days lead to much greater increases in the death rate in India than they do in the US $(0.74 \%$ vs $0.03 \%$ ), but that this difference is explained by the rural areas of India. In urban areas, there are no differences between both countries, suggesting cities somehow protect the population from the deleterious effects of extreme heat.

We contribute to this debate in the developing world by estimating the effects of temperature and precipitation variations on mortality rates for several 
age groups using an annual panel of 2,198 Brazilian municipalities from 1980 to 2012. This rich dataset has a great climate variability, ranging from subtropical to equatorial areas, since Brazil is a continental size country. We interact weather deviations and climate normals to explore this climate variablity and to account for non-linear weather effects and find that not only temperature, but also precipitation increases mortality rates among the infant and elderly. The infant are specially susceptible to precipitation. The richness of our data allow us to further test if these effects on infants vary by levels of infrastructure, education and income and by geographical regions. Results suggest that they are more affected by temperature in cities with low levels of education and infrastructure. Precipitation, on the other hand, affects infants more in cities with high levels of education and infrastructure. Infants in the Northeast and Midwest regions are the most impacted.

Since the beginning of the 21st century, a great body of research has emerged trying to understand how climate is shaping modern society. There are evidences of effects on labor productivity, agriculture/industry outputs, conflicts, economic growth, migration, health and others (Dell, Jones e Olken (2012)). Future climatic changes are expected to have an additional impact (Carleton e Hsiang (2016);Dasgupta (2010)). When it comes to mortality, heat seem to aggravate preexisting comorbidities such as cardiovascular, cerebrovascular and respiratory diseases, with elderly, infants, and persons of low socioeconomic status being the most vulnerable (Song et al. (2017), Basu e Samet (2002), Curriero et al. (2002)).

We match an annual mortality database, sourced from the Brazilian Unified Health System (SUS), with a grid of temperature and precipitation generated by Xavier, King e Scanlon (2017) at national level from 1980 to 2012. This is the first work to estimate weather effects at national level for a long period (33 years) in Brazil. Other works for the country have focused their attention to birth outcomes in the Brazilian semiarid (Rocha e Soares (2015)) and agricultural outputs in the same region (Motta et al. (2011), Sun, Li e Ward (2007)) or mortality rates, but only in the city of São Paulo (Son et al. (2016), Gouveia, Hajat e Armstrong (2003)). We further gather demographic information from the Brazilian Bureau of Statistics (IBGE) and from the Institute of Applied Economic Research (IPEA) that allow us to study heterogeneous effects by region, income, education and infrastructure. 
We interact weather deviations with climate normals to explore Brazil's rich climate heterogeneity and estimate non-linear weather effects on different outcomes. The use of weather deviations from climate normal avoids imposing strong hypotheses on the relationship between weather and the outcome variable (Mendelsohn, Pereda e Wade (2019)). The non-linear relationship of weather comes from the interaction between weather deviations $\left(\Delta T_{i t}, \Delta P_{i t}\right)$ and climate normals $\left(\bar{T}_{i}, \bar{P}_{i}\right)$. We use municipal and year fixed effects to control for other possible confounders in the same way Deschenes e Greenstone (2011), and ultimately rest on the weather unpredictability for causal inference.

Our results show that positive precipitation shocks $(+1 \mathrm{~mm})$ in a rainy season, increase mortality rates by $0.1 / 100,000$ inhabitants among children between 0 and 4 years old, which is around $0.02 \%$ of the average. This result dialogues with the work of Rocha e Soares (2015) that finds impacts of rainfall on infant mortality in the Brazilian semiarid and is associated to the literature that relates humidity and mortality (Geruso e Spears (2018), Zhang et al. (2014) and Barreca (2012)). Our estimates suggest children aged 0 to 4 years old is the most affected age group of our sample (Xu et al. (2012)).

We then focus on estimating demographic heterogeneities for children. We find that shocks of $1{ }^{\circ} \mathrm{C}$ in the cold season reduce children mortality rates by $0.8 / 100,000$ in cities with low education $(0.17 \%)$ and by $0.3 / 100,000$ in cities with low infrastructure $(0.07 \%)$. On the warm season, however, this same shock increase mortality rates by $0.3 / 100,000$ in cities with low infrastructure $(0.07 \%)^{3.1 .1}$. Positive precipitation shocks of $1 \mathrm{~mm}$, on the other hand, increase mortality rates by $0.5 / 100,000$ in cities with high education levels $(0.08 \%)$ and by $0.5 / 100,000$ in cities with high levels of infrastructure $(0.08 \%)$.

As for region heterogeneity, children are more affected by weather variations in the Northeast and Midwest regions. Positive temperature shocks in the cold season reduce children mortality rates by $0.2 / 100,000$ in the Midwest region $(0.04 \%)$ and by $0.7 / 100,000$ in the Northeast region $(0.13 \%)$. On the warm season, positive temperature shocks increase mortality by $0.3 / 100,000$ only in the Midwest region

\footnotetext{
3.1.1 See Burgess et al. (2017), Barreca et al. (2016), Barreca et al. (2015), Deschênes e Moretti (2009) and Huynen et al. (2001) for the relation between heat and mortality
} 
(0.06\%). A $1 \mathrm{~mm}$ positive precipitation shock in the dry season reduce mortality rates by $0.2 / 100,000$ in the Northeast region $(0.04 \%)$. This result ressembles the findings of Rocha e Soares (2015) that found evidences that increases in rainfall in the Brazilian semiarid (Northeast region) reduced infant mortality rates.

This paper is divided as follows. Section 3.2 describes the data sources and outlines the empirical strategy. Section 3.3 presents the baseline results and the analysis by demographic groups and regions. Section 3.4 concludes. 


\subsection{Data and empirical strategy}

This work uses a panel model to understand the relation between weather variations and mortality using annual Brazilian municipality level data from 1980 until 2012. More than 1,500 municipalities have been created in Brazil in this period (Table 3.2.1) and for this reason, to make comparisons consistent over time it is necessary to aggregate them in broader geographical areas, named Minimum Comparable Areas, or AMCs in the Portuguese acronym (Reis et al. (2011)). So, the panel units used in this work are the Brazilian municipalities with their spatial configuration as they were in 1980 .

Table 3.2.1 - Number of municipalities in Brazil and macro-regions, Brazilian Census 1980-2010

\begin{tabular}{lllll} 
& $\mathbf{1 9 8 0}$ & $\mathbf{1 9 9 1}$ & $\mathbf{2 0 0 0}$ & $\mathbf{2 0 1 0}$ \\
\hline Brazil & 3991 & 4491 & 5507 & 5565 \\
\hline North & 203 & 298 & 449 & 449 \\
\hline Northeast & 1375 & 1509 & 1787 & 1794 \\
\hline Southeast & 1410 & 1432 & 1666 & 1668 \\
\hline South & 719 & 873 & 1159 & 1188 \\
\hline Midwest & 284 & 379 & 446 & 466
\end{tabular}

Notes: Table shows the number of Brazilian municipalities by macro-region in each Brazilian Census since 1980. Source: The Brazilian Bureau of Statistics (IBGE), Brazilian Census 1980, 1991, 2000 and 2010.

In order to estimate the relation between weather and mortality in Brazil, we use information from many sources. The mortality rates, our dependent variables, are sourced from the Brazilian Unified Health System (SUS), which is the public health system responsible for achieving the goal of universal health coverage in the country (Castro, Spolador e Marin (2019)). The weather, or independent variables, were obtained in the work of Xavier, King e Scanlon (2017), which interpolate historical temperature and precipitation for the country. Other demographic information, used in our heterogeneity exercises, such as income, education and 
infrastructure, were obtained from the Brazilian Bureau of Statistics (IBGE) and from the Institute of Applied Economic Research (IPEA). The Appendix Table 3.4.1 presents a description of each variable used in this work, along with its source, measuring unit and period available. More details on these variables are provided in the subsections below.

\subsubsection{Mortality data}

Annual mortality information at municipality level is sourced from the Brazilian Unified Health System (SUS) and standardized for deaths per 100,000 inhabitants to make them comparable across units. It is calculated by age groups by summing all deaths in an age group and dividing by the total number of individuals in that age group, times 100,000 (see Appendix Table 3.4.1). Mortality data is available for eleven age groups: 0 to 4 years old; 5 to 9 years old; 10 to 14 years old; 15 to 19 years old; 20 to 29 years old; 30 to 39 years old; 40 to 49 years old; 50 to 59 years old; 60 to 69 years old; 70 to 79 years old; and 80 years old or more. In order to standardize deaths in each age group we used the corresponding population of that age group. The Appendix Table 3.4.2 presents the number of observations for each age group and year of the sample. There is no official population count at municipal level after 2012, so it limits our sample to the period between 1980 and 2012 .

Figure 3.2.1 presents the evolution of average mortality rates (per 100,000 inhabitants) by Brazilian macro-regions and age groups. For scaling reasons, we separate our figure in two. Top figure presents mortality rates for those above 50 years old, while the bottom figure presents mortality rates for the remaining groups. We can note considerable declines in mortality rates for the following age groups: 0-4 yo; 40-49 yo; 70-79 yo and $80+$ yo. As for the mortality levels, the South and Southeast regions present the highest rates, but they considerably fell over time. Appendix Tables 3.4.3 to 3.4.8 detail these average mortality rates per macro-region, year and age group. 
Figure 3.2.1 - Historical evolution of average mortality rates by region and age group, Brazil 1980-2012
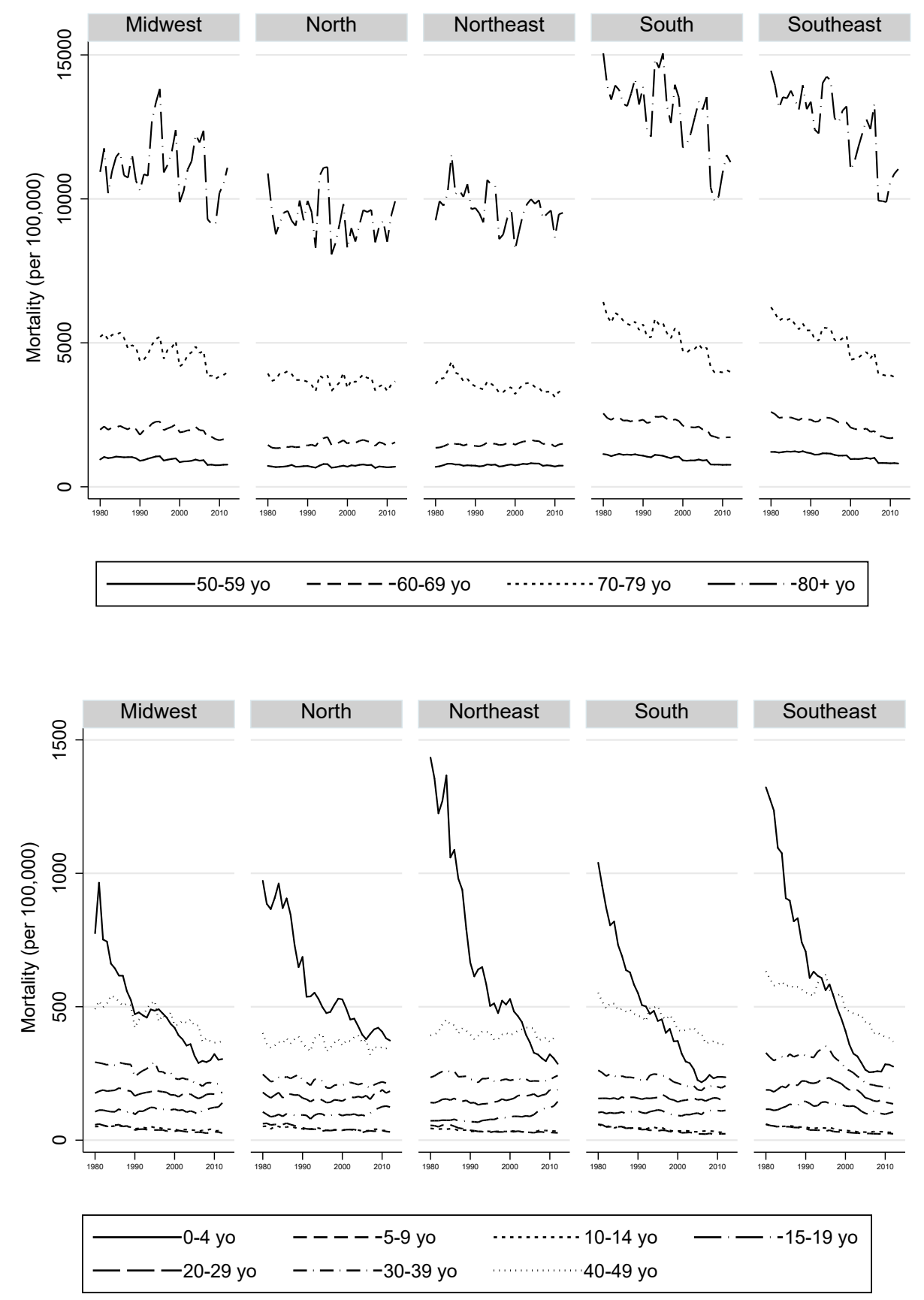

Notes: Figure shows the evolution of average mortality rates (per 100,000 inhabitants) by Brazilian macro-regions and age groups. For scaling reasons, we separate our figure in two. Top figure presents mortality rates for the oldest age groups - above 50 years old - while the bottom figure presents mortality rates for the remaining groups. 


\subsubsection{Weather data}

We use data on daily temperature and precipitation generated by Xavier, King e Scanlon (2017). ${ }^{32.1}$ The authors use historical weather observations collected from rain gauges and conventional and automatic weather stations from the 'Instituto Nacional de Meteorologia' (INMET), the 'Agência Nacional de Águas' (ANA), and 'Departamento de Águas e Energia Elétrica de São Paulo' (DAEE). Temperature is available for all Brazilian territory starting in January of 1980 and ending in June of 2017. Precipitation is available from January of 1980 to December of 2016. The spatial resolution of the grids is $0.25^{\circ} \times 0.25^{\circ}$, resulting in 27,216 points (162 latitudes and 168 longitudes).

Grid-level data were converted to municipality-level data as follows. For latitude-longitude pairs which fell inside a municipality's boundaries, the average temperature and precipitation of those grids was considered as belonging to the municipality. When latitude-longitude pairs did not belong to the municipality polygon, we use the measure of weather of the closest grid to the municipality centroid within a $0.5^{\circ}(\sim 55 \mathrm{~km})$ range. Based on these assumptions we were able to match weather data for 3,226 out of 5,570 existing municipalities in the country. However, as explained in the beginning of this section, these municipalities were further aggregated in broader geographical areas (AMCs) that existed in 1980 to the sake of comparability through time. After the aggregation we ended up with 2,198 AMCs as our panel variable. They represent around 55\% of the 3,991 AMCs that existed in 1980 (see Table 3.2.1). There are smaller municipalities that are being excluded from our database because they do not pass our matching criterion. We argue this is not a problem for estimations unless weather affects these municipalities differently from larger ones.

After we assign daily grid-level data to each AMC, we calculate yearly

\footnotetext{
3.2.1 The authors compare six different techniques of data interpolation by using data from 3,625 rain gauges (for rainfall) and 735 weather stations (for temperatures). They conclude that the inverse distance weighting and angular distance weighting interpolation techniques are the best way of interpolating stations/rain gauges to the whole Brazilian territory. We use the interpolated data that performed better in their tests.
} 
averages $\left(T_{i t}, P_{i t}\right)$, as we did with mortality, and then calculate the climate normal over the 1980-2012 period $\left(\bar{T}_{i}, \bar{P}_{i}\right)$ so we can construct the variables $\Delta T_{i t}=\left(T_{i t}-\bar{T}_{i}\right)$ and $\Delta P_{i t}=\left(P_{i t}-\bar{P}_{i}\right)$ from Equation 3.2.1. ${ }^{3.2 .2}$ Figure 3.2.2 show the distribution of weather and climate normals. The temperature resembles a bimodal distribution since Brazil is a continental size country, with the presence of tropical and temperate zones. The precipitation distribution is also bimodal due to rainy regions as the Amazon Rainforest and a semiarid region in the Northeast, but is also positively skewed since there is little rain in the majority of the days. The climate variables present similar distributions ${ }^{3.2 .3}$.

Figure 3.2.3 shows the distribution of temperature and precipitation deviations from their climate normals. Due to the large regional heterogeneity in the Brazilian climate, we present these distributions by macro-region ${ }^{3.2 .4}$. Because deviations are calculated as the yearly difference between weather and climate, a negative (positive) value means that the year was colder (hotter) than the climate normal. All temperature distributions are normal. They range from $-4^{\circ} \mathrm{C}$ to $+4^{\circ} \mathrm{C}$ and are more sparsely distributed in Northeast, South and Southeast regions. As for precipitation, it ranges from $-4 \mathrm{~mm} /$ day to $+8 \mathrm{~mm} /$ day. The North, Northeast and Southeast regions present the greater variances.

\footnotetext{
3.2.2 Appendix Figures 3.4.1, 3.4.2 and 3.4.3 present the climate distributions and additional weather statistics by macro-region.

${ }^{3.2 .3}$ Appendix Figures 3.4.4 and 3.4.5 show, respectively, the geographical distribution of temperature and precipitation in the sample extracted from the work of Xavier, King e Scanlon (2017)

3.2.4 The Brazilian Bureau of Statistics (IBGE) divides the country into five macro-regions: North (NO), Northeast (NE), Southeast (SE), South (SO), and Midwest (MW).
} 
Figure 3.2.2 - Distribution of weather variables and climate normals, Brazil $1980-2012$
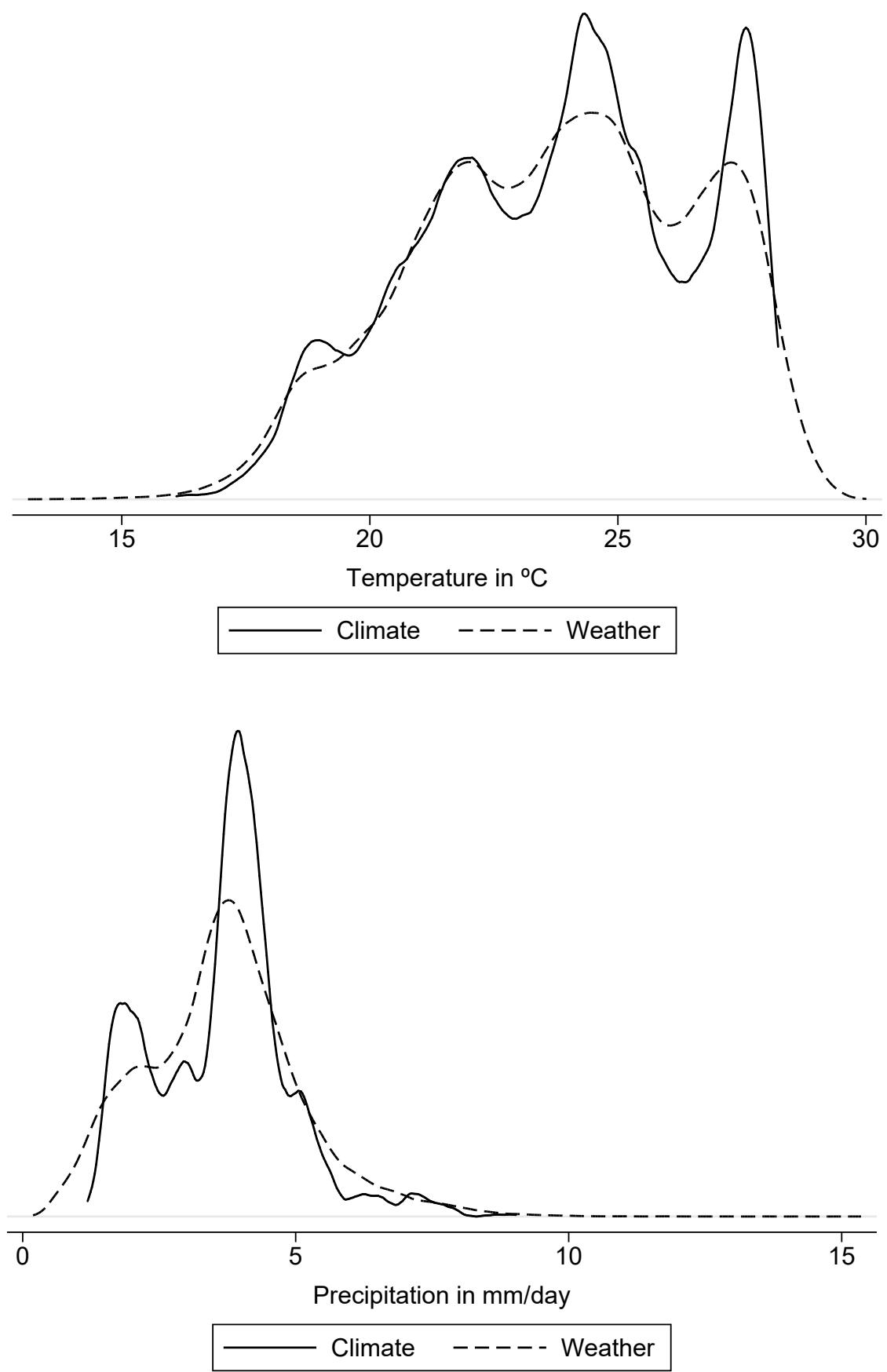

Notes: Figure shows the distribution of weather variables and climate normals in Brazil from 1980 to 2012 . Temperature is presented in ${ }^{\circ} \mathrm{C}$ and precipitation $\mathrm{mm} /$ day. 
Figure 3.2.3 - Temperature and precipitation deviations from climate normals by macro-region, Brazil 1980-2012
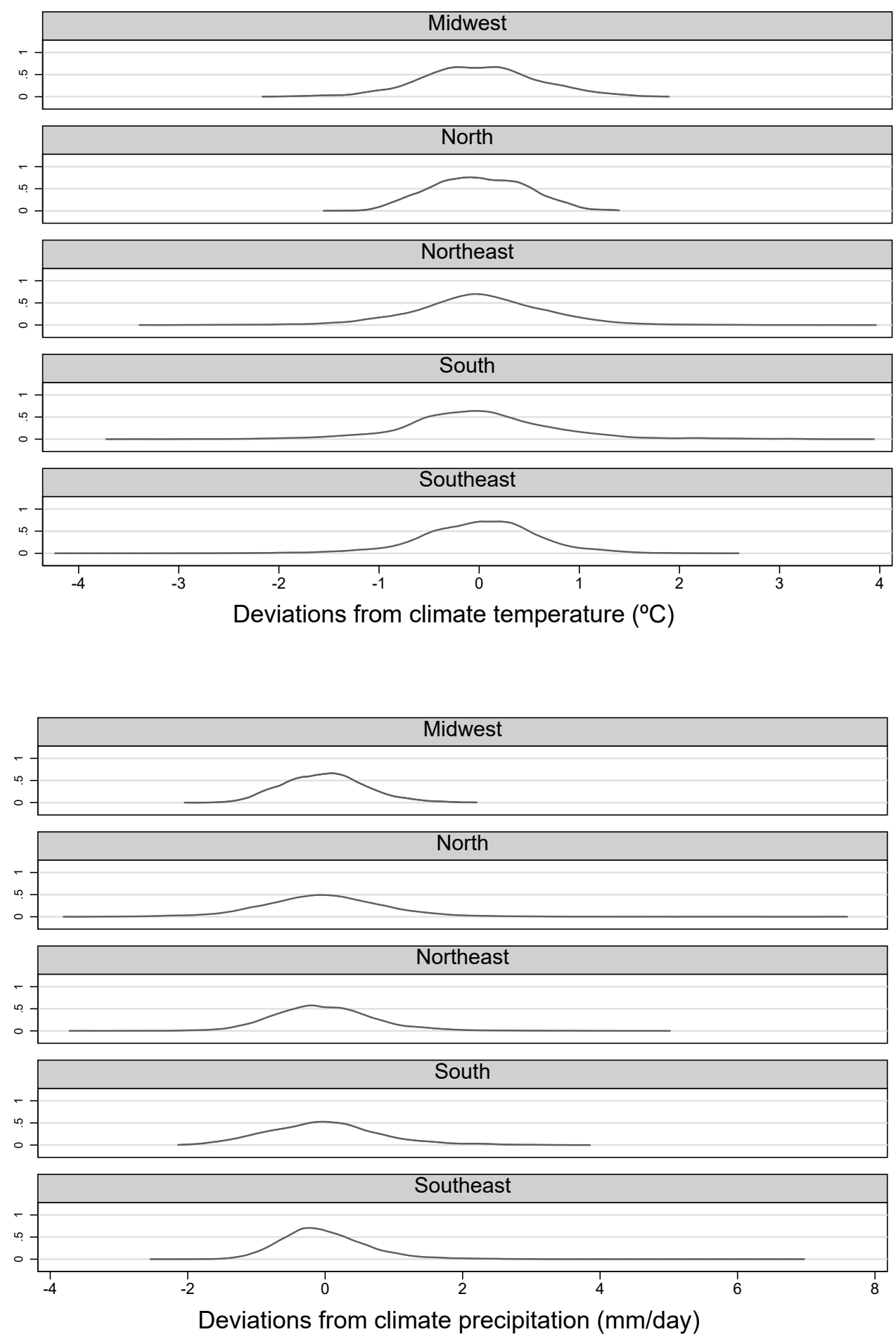

Notes: Figure shows temperature (in ${ }^{\circ} \mathrm{C}$ ) and precipitation (in $\mathrm{mm} /$ day) deviations from climate normals by macro-regions. Deviations are calculated yearly in the period 1980-2012. 


\subsubsection{Demographic variables}

In our estimates we perform an investigation of heterogeneous effects by demographic group. To that end, we use variables to represent earnings, education and infrastructure of municipalities in 1980. We use the variables in the first year of our sample so they will not be correlated to the mortality rates.

The per capita total earnings in 1980 are sourced from the Brazilian Bureau of Statistics (IBGE). They are calculated as the sum of all earnings divided by total population of the city.

We use two different measures of education. The first is the average education (in years) in 1980 considering 25 year-old citizens or older. It is calculated at city level as the sum of years of education achieved by 25 year-old people or older, divided by total population in this age group. The second is the average educational gap in 1980. The educational gap is defined as the difference between recommended years of education and actual years of education based on a persons age. It is calculated at city level by the sum of the educational gap for kids between 10 and 14 years-old, divided by the total number of children in this age group. Educational information was sourced from the Institute of Applied Economic Research (IPEA).

As for infrastructure, we use three different measures. The first is water access and represents the proportion of houses with water access in 1980 in a given city. It is calculated as the number of houses with access to the local water network, divided by the total number of houses. The second is sewage access and represents the proportion of houses of a city connected with the sanitation network in 1980. It is calculated as the number of houses with access to sewage network, divided by the total number of houses. The last is electricity access and represents the proportion of houses in a city with electricity access in 1980. It is calculated as the number of houses with access to electricity network, divided by the total number of houses.

All these variables are defined in the Appendix Table 3.4.1 and a brief summary of this variables is presented in Table 3.2.2. 
Table 3.2.2 - Summary statistics of variables used in the demographic heterogeneity exercise, Brazil 1980

\begin{tabular}{lcccccccc}
\hline \hline & Obs & Mean & SD & Min & p25 & Median & p75 & Max \\
\hline Earnings & 72,534 & 0.11 & 0.06 & 0.01 & 0.06 & 0.10 & 0.15 & 0.45 \\
Water & 61,776 & 0.27 & 0.20 & 0.00 & 0.11 & 0.22 & 0.40 & 0.93 \\
Electricity & 72,501 & 0.42 & 0.27 & 0.00 & 0.19 & 0.35 & 0.63 & 0.98 \\
Sewage & 25,443 & 0.29 & 0.21 & 0.00 & 0.11 & 0.26 & 0.43 & 0.86 \\
Education & 72,534 & 2.03 & 1.06 & 0.10 & 1.10 & 1.90 & 2.80 & 6.70 \\
Educ gap & 72,534 & 2.99 & 0.92 & 1.10 & 2.20 & 2.90 & 3.90 & 4.90 \\
\hline \hline
\end{tabular}

Notes: Table presents summary statistics of the variables used in our heterogeneity exercise by demographic groups. We presente the number of observations (Obs), mean, standard deviation (SD), minimum, percentile $25 \%$ (p25), median, percentile $75 \%$ (p75) and maximum. Variables refer to the year of 1980 and their definitions are presented in the Appendix Table 3.4.1.

\subsubsection{Empirical strategy}

We estimate a simple model to understand the effect of temperature and precipitation on mortality rates. Because the empirical literature shows that this relationship might be non-linear, our model interacts weather deviations with climate normals when estimating non-linear weather effects on different outcomes, as Mendelsohn, Pereda e Wade (2019) highlighted. The use of weather deviations from long-term temperature avoids the demeaning problem of the quadratic term. To illustrate that, in a simple model using panel data - such that $y_{i t}=\alpha_{0}+$ $\alpha_{1} x_{i t}+\alpha_{2} x_{i t}^{2}+\lambda_{i}+\varepsilon_{i t}$ - the within equation can be written as $\left(y_{i t}-E\left[y_{i t}\right]\right)=$ $\alpha_{1}\left(x_{i t}-E\left[x_{i t}\right]\right)+\alpha_{2}\left(x_{i t}^{2}-E\left[x_{i t}\right]^{2}\right)+\left(\varepsilon_{i t}-E\left[\varepsilon_{i t}\right]\right)$. As $x_{i t}$ represents a temperature level (which we can decompose into a deviation from long term average, $\Delta x_{i t}$, plus the long-term average, $\left.E\left[x_{i t}\right]\right)$, Mendelsohn, Pereda e Wade (2019) show that $\left(x_{i t}^{2}-E_{t}\left[x_{i t}^{2}\right]\right)=2 E\left[x_{i t}\right] \Delta x_{i t}+\left(\Delta x_{i t}\right)^{2}-E_{t}\left[\Delta x_{i t}^{2}\right]$. To avoid imposing hypotheses on the relationship between these variables and the outcome variable, we include the deviations and its interactions with long-term averages (climate normals) as follows:

$$
M_{i t}=\alpha_{0}+\alpha_{1} \Delta T_{i t}+\alpha_{2} \Delta T_{i t} * \bar{T}_{i}+\alpha_{3} \Delta P_{i t}+\alpha_{4} \Delta P_{i t} * \bar{P}_{i}+\alpha_{i}+\alpha_{t}+\epsilon_{i t},
$$


where $M_{i t}$ is the mortality rate of city $i$ in year $t ; \Delta T_{i t}$ and $\Delta P_{i t}$ denote the temperature and precipitation deviations from the climate in city $i$ and year $t$; and $\bar{T}_{i}$ and $\bar{P}_{i}$ are the municipality's climate normal. ${ }^{3.2 .5}$ The remaining parameters, $\alpha_{i}$, and $\alpha_{t}$ denote municipality and year fixed effects; $\epsilon_{i t}$ is the idiosyncratic error term.

In our model, the non-linearity of the temperature comes from the fact that weather effects might vary across climates (which we measure by the long-run averages, $\bar{T}_{i}$ and $\left.\bar{P}_{i}\right)$. We expect a different impact of a $1^{\circ} \mathrm{C}$ increase in temperatures from a $20^{\circ} \mathrm{C}$ climate than from a $30^{\circ} \mathrm{C}$ climate. The same idea applies to precipitation.

We use municipal and year fixed effects to control for other possible confounders in the same way Deschenes e Greenstone (2011). A municipality fixed effect parameter is important because it holds constant time-invariant municipality attributes that correlate with weather (and climate) and outcomes, such as permanent differences in hospital quality or overall healthiness of the local population. On its turn, year fixed effects are important to control for time-varying health policies that are common across municipalities. All regressions are weighted by the average population of the city between 1980 and 2012 and clustered by states.

We ultimately rest on the weather unpredictability for causal inference. In other words, our empirical exercise is valid if (unpredictable) weather fluctuations are not correlated to any omitted variable that determines mortality rates. One must be cautious, however, about using our estimates to quantify climate change impacts on mortality. ${ }^{3.2 .6}$

\footnotetext{
${ }^{3.2 .5}$ We calculate the climate temperature and precipitation by taking the average of historical climate data, from 1980 to 2012.

${ }^{3.2 .6}$ Our equation examines the effect of a deviation in yearly weather on mortality, not considering potential adaptation behavior. Many papers of the literature that also explore annual panel data show that the results cannot be extended to understand climate change effects (Deschenes e Greenstone (2007), Schlenker e Roberts (2009), and Dell, Jones e Olken (2012)).
} 


\subsection{Results}

\subsubsection{Main results}

Table 3.3.1 presents the estimates of weather impact on mortality rates for various specifications, with and without city fixed effects, state clusters and precipitation. The weather interaction with climate normals captures how weather deviations impact different climates. All regressions include year fixed effects. Results show the non-linearities in the weather effects on mortality rates are likely relevant given the statistical significance of the interaction term for temperature or precipitation in all specification it appears. Also, adding city fixed effects to the model slightly changes the magnitude of the coefficients. Additionally, the signal inversion of temperature and precipitation shocks (negative to positive marginal effects) occurs at the same level (around $22^{\circ} \mathrm{C}$ and $4 \mathrm{~mm}$, respectively) independently of the specification. Our preferred specification is the one in the last column of Table 3.3.1 and includes year and municipal fixed effects, as well as state clusters.

Tables 3.3.2 and 3.3.3 applies our preferred specification to all dependent variables: 0 to 4 years old; 5 to 9 years old; 10 to 14 years old; 15 to 19 years old; 20 to 29 years old; 30 to 39 years old; 40 to 49 years old; 50 to 59 years old; 60 to 69 years old; 70 to 79 years old; and 80 years old or more. Only adults between 60 and 79 years old are impacted by temperature, while children between 0 and 4 years old are impacted by precipitation. Adults between 40 and 49 years old and between 70 and 79 years old are also affected by temperature, but results are just marginally significant.

Figure 3.3.1 presents the significant marginal effects calculated from Tables 3.3.2 and 3.3.3. In the Top of Figure 3.3.1 we calculate the impact of a $\Delta$ Prec $=+1 \mathrm{~mm}$ for different levels of $\bar{P}$. This is our main result and shows that positive precipitation shocks when climate precipitation is already high, which is equivalent to a rainy season, tends to increase mortality rates by $0.1 / 100,000$ inhabitants among children between 0 and 4 years old. This is an increase of approximately $0.02 \%$ considering the national average mortality rate of this age 
group between 1980 and $2012^{3.3 .1}$. This result dialogues with the literature that finds impacts of humidity and mortality (Geruso e Spears (2018), Zhang et al. (2014) and Barreca (2012)). In the Bottom of Figure 3.3.1 we calculate the impact of a $\Delta T e m p=+1^{\circ} \mathrm{C}$ for different levels of $\bar{T}$ for people between $60-69$ yo and 70-79 yo. As expected, the marginal effects are positive and significant, but only when temperatures are below $20^{\circ} \mathrm{C}$. Evidence suggest that mortality is reduced by 0.5/100,000 among these age groups when temperatures are below this threshold and increase with temperature, but without reaching significant levels in warm seasons.

Our estimates suggest children between 0 and 4 years are the most affected by weather variations, which is reinforced by the literature (Xu et al. (2012)). Brazil is a continental size country with great regional disparities and very different climates, so these effects may change depending on the development level and region. To investigate these issues further, in the next sections we check for heterogeneous effects of weather shocks on children mortality rates along two dimensions: demographics and macro-region.

${ }^{3.3 .1}$ We calculate this percentage dividing the $0.1 / 100,000$ calculated increase by the national average mortality rate of the 0-4 year old age group between the sample period of 1980 and 2012, which is 554.1 deaths per 100,000 inhabitants 
Table 3.3.1 - Impact of weather shocks on mortality rates - Baseline results for children aged 0 to 4, Brazil 1980-2012

\begin{tabular}{|c|c|c|c|c|c|}
\hline & $\begin{array}{c}(1) \\
0-4 \text { yo }\end{array}$ & $\begin{array}{c}(2) \\
0-4 \text { yo }\end{array}$ & $\begin{array}{c}(3) \\
0-4 \text { yo }\end{array}$ & $\begin{array}{c}(4) \\
0-4 \text { yo }\end{array}$ & $\begin{array}{c}(5) \\
0-4 \text { yo }\end{array}$ \\
\hline$\Delta T e m p$ & $\begin{array}{l}-20.82^{*} \\
(6.19)\end{array}$ & $\begin{array}{l}* 144.73^{* *} \\
(44.53)\end{array}$ & $\begin{array}{l}*-144.73 \\
(168.59)\end{array}$ & $\begin{array}{c}-123.14 \\
(181.66)\end{array}$ & $\begin{array}{l}-153.02 \\
(191.63)\end{array}$ \\
\hline$(\Delta T e m p) \cdot \bar{T}$ & & $\begin{array}{l}5.38^{* * *} \\
(2.05)\end{array}$ & $\begin{array}{c}5.38 \\
(7.61)\end{array}$ & $\begin{array}{c}4.36 \\
(8.28)\end{array}$ & $\begin{array}{c}5.55 \\
(8.71)\end{array}$ \\
\hline$\Delta$ Prec & & & & $\begin{array}{l}-71.76^{* *} \\
(32.13)\end{array}$ & $\begin{array}{l}-67.82^{\text {** }} \\
(32.15)\end{array}$ \\
\hline$(\Delta$ Prec $) \cdot \bar{P}$ & & & & $\begin{array}{l}15.79^{* *} \\
(5.76)\end{array}$ & $\begin{array}{l}15.20^{* *} \\
(5.71)\end{array}$ \\
\hline Obs & 45,565 & 45,565 & 45,565 & 45,565 & 45,539 \\
\hline Mean of dep. var. & 554.1 & 554.1 & 554.1 & 554.1 & 554.1 \\
\hline Temp. Inv. $\left({ }^{\circ} \mathrm{C}\right)$ & & 26.9 & 26.9 & 28.3 & 27.6 \\
\hline Prec. Inv. (mm) & & & & 4.5 & 4.5 \\
\hline R-squared & 0.0009 & 0.0014 & 0.0014 & 0.0029 & 0.0058 \\
\hline Year FE & Yes & Yes & Yes & Yes & Yes \\
\hline State cluster & No & No & Yes & Yes & Yes \\
\hline Municipal FE & No & No & No & No & Yes \\
\hline
\end{tabular}

Notes: Table compares different specifications for the regression of infant (aged 0 to 4) mortality rates in terms of the inclusion or not of city fixed effects, state clusters and weather variables: temperature and precipitation deviations from climate normals $(\Delta T e m p, \Delta$ Prec $)$ and its interactions with climate $((\Delta$ Temp $) \cdot \bar{T},(\Delta$ Prec $) . \bar{P})$. All regressions are weighted by the average population of the city between 1980 and 2012. Temp inv. $\left({ }^{\circ} \mathrm{C}\right)$ and Prec inv. $(\mathrm{mm})$ are, respectively, the temperature and precipitation inflection points considering $\Delta T e m p=0$ and $\Delta \operatorname{Prec}=0$ (n.a. means not applicable, as the linear term does not present signal inversion). 
Table 3.3.2 - Impact of weather shocks on mortality rates for people aged 0 to 29, Brazil 1980-2012

\begin{tabular}{lccccc}
\hline \hline & & & & & \\
& $0-4$ yo & $5-9$ yo & $10-14$ yo & $15-19$ yo & $20-29$ yo \\
\hline$\Delta$ Temp & -153.02 & -1.69 & -9.20 & $-37.32^{* *}$ & $-42.84^{* *}$ \\
& $(191.63)$ & $(6.45)$ & $(6.29)$ & $(16.58)$ & $(19.33)$ \\
$(\Delta$ Temp $) . \bar{T}$ & 5.55 & 0.03 & 0.35 & $1.55^{* *}$ & $1.71^{* *}$ \\
& $(8.71)$ & $(0.29)$ & $(0.28)$ & $(0.71)$ & $(0.83)$ \\
$\Delta$ Prec & & & & & \\
& $-67.82^{* *}$ & -0.17 & 0.45 & 2.03 & 3.79 \\
& $(32.15)$ & $(1.03)$ & $(1.11)$ & $(3.88)$ & $(4.14)$ \\
$\Delta$ Prec).P & $15.20^{* *}$ & 0.04 & -0.07 & -0.54 & -0.81 \\
& $(5.71)$ & $(0.21)$ & $(0.21)$ & $(0.84)$ & $(0.80)$ \\
\hline Obs & 45,539 & 36,212 & 37,249 & 48,272 & 62,550 \\
Mean of dep. var. & 554.1 & 36.3 & 38.5 & 102.4 & 167.9 \\
Temp. Inv. $\left({ }^{\circ} \mathrm{C}\right)$ & 27.6 & 59.8 & 26.5 & 24.2 & 25.0 \\
Prec. Inv. $(\mathrm{mm})$ & 4.5 & 4.6 & 6.5 & 3.8 & 4.7 \\
R-squared & 0.0058 & 0.0007 & 0.0019 & 0.0049 & 0.0048 \\
Year FE & Yes & Yes & Yes & Yes & Yes \\
State cluster & Yes & Yes & Yes & Yes & Yes \\
Municipal FE & Yes & Yes & Yes & Yes & Yes \\
\hline \hline
\end{tabular}

Notes: Table applies our preferred specification, which includes time fixed effects, city fixed effect and state clusters, to different dependent variables for people aged 0 to 29 years old. All regressions are weighted by the average population of the city between 1980 and 2012. Weather variables used are temperature and precipitation deviations from climate normals $(\Delta T e m p, \Delta$ Prec $)$ and its interactions with climate $((\Delta$ Temp $) \cdot \bar{T},(\Delta$ Prec $) \cdot \bar{P})$. Temp inv. $\left({ }^{\circ} \mathrm{C}\right)$ and Prec inv. $(\mathrm{mm})$ are, respectively, the temperature and precipitation inflection points considering $\Delta T e m p=0$ and $\Delta P r e c=0$ (n.a. means not applicable, as the linear term does not present signal inversion). 
Table 3.3.3 - Impact of weather shocks on mortality rates for people aged 30 to $80+$, Brazil 1980-2012

\begin{tabular}{lcccccc}
\hline \hline & & & & & \\
& $30-39$ yo & $40-49$ yo & $50-59$ yo & $60-69$ yo & $70-79$ yo & $80+$ yo \\
\hline$\Delta$ Temp & -28.18 & $-71.38^{* *}$ & $-188.91^{* * *}-508.85^{* * *}-763.61^{* *}$ & -558.47 \\
& $(22.02)$ & $(34.01)$ & $(64.57)$ & $(151.85)$ & $(298.37)$ & $(512.32)$ \\
$(\Delta$ Temp $) . \bar{T}$ & & & & & & \\
& 0.85 & 2.44 & $7.37^{* *}$ & $20.32^{* * *}$ & $29.10^{* *}$ & 14.06 \\
& $(0.96)$ & $(1.46)$ & $(2.72)$ & $(6.48)$ & $(12.75)$ & $(21.93)$ \\
$\Delta$ Prec & & & & & & \\
& 0.08 & -1.87 & -9.63 & 6.98 & 12.20 & -102.38 \\
& $(4.96)$ & $(8.96)$ & $(16.60)$ & $(30.13)$ & $(70.64)$ & $(128.22)$ \\
$(\Delta$ Prec).P & 0.47 & 1.27 & 3.87 & 3.71 & 6.24 & 39.29 \\
& $(0.96)$ & $(1.76)$ & $(3.26)$ & $(5.66)$ & $(13.62)$ & $(24.42)$ \\
\hline Obs & 64,859 & 67,186 & 68,648 & 69,643 & 70,104 & 69,363 \\
Mean of dep. var. & 243.2 & 442.1 & 898.2 & $1,856.1$ & $4,273.5$ & $10,926.9$ \\
Temp. Inv. $\left({ }^{\circ} \mathrm{C}\right)$ & 33.2 & 29.3 & 25.6 & 25.0 & 26.2 & 39.7 \\
Prec. Inv. $(\mathrm{mm})$ & n.a. & 1.5 & 2.5 & n.a. & n.a. & 2.6 \\
R-squared & 0.0061 & 0.0090 & 0.0090 & 0.0158 & 0.0093 & 0.0045 \\
Year FE & Yes & Yes & Yes & Yes & Yes & Yes \\
State cluster & Yes & Yes & Yes & Yes & Yes & Yes \\
Municipal FE & Yes & Yes & Yes & Yes & Yes & Yes \\
\hline \hline
\end{tabular}

Notes: Table applies our preferred specification, which includes time fixed effects, city fixed effect and state clusters, to different dependent variables for people aged 30 to $80+$ years old. All regressions are weighted by the average population of the city between 1980 and 2012. Weather variables used are temperature and precipitation deviations from climate normals $(\Delta T e m p$, $\Delta$ Prec $)$ and its interactions with climate $((\Delta$ Temp $) \cdot \bar{T},(\Delta$ Prec $) \cdot \bar{P})$. Temp inv. $\left({ }^{\circ} \mathrm{C}\right)$ and Prec inv. $(\mathrm{mm})$ are, respectively, the temperature and precipitation inflection points considering $\Delta$ Temp $=0$ and $\Delta P r e c=0$ (n.a. means not applicable, as the linear term does not present signal inversion). 
Figure 3.3.1 - Marginal effects of weather shocks on mortality rates, Brazil $1980-2012$
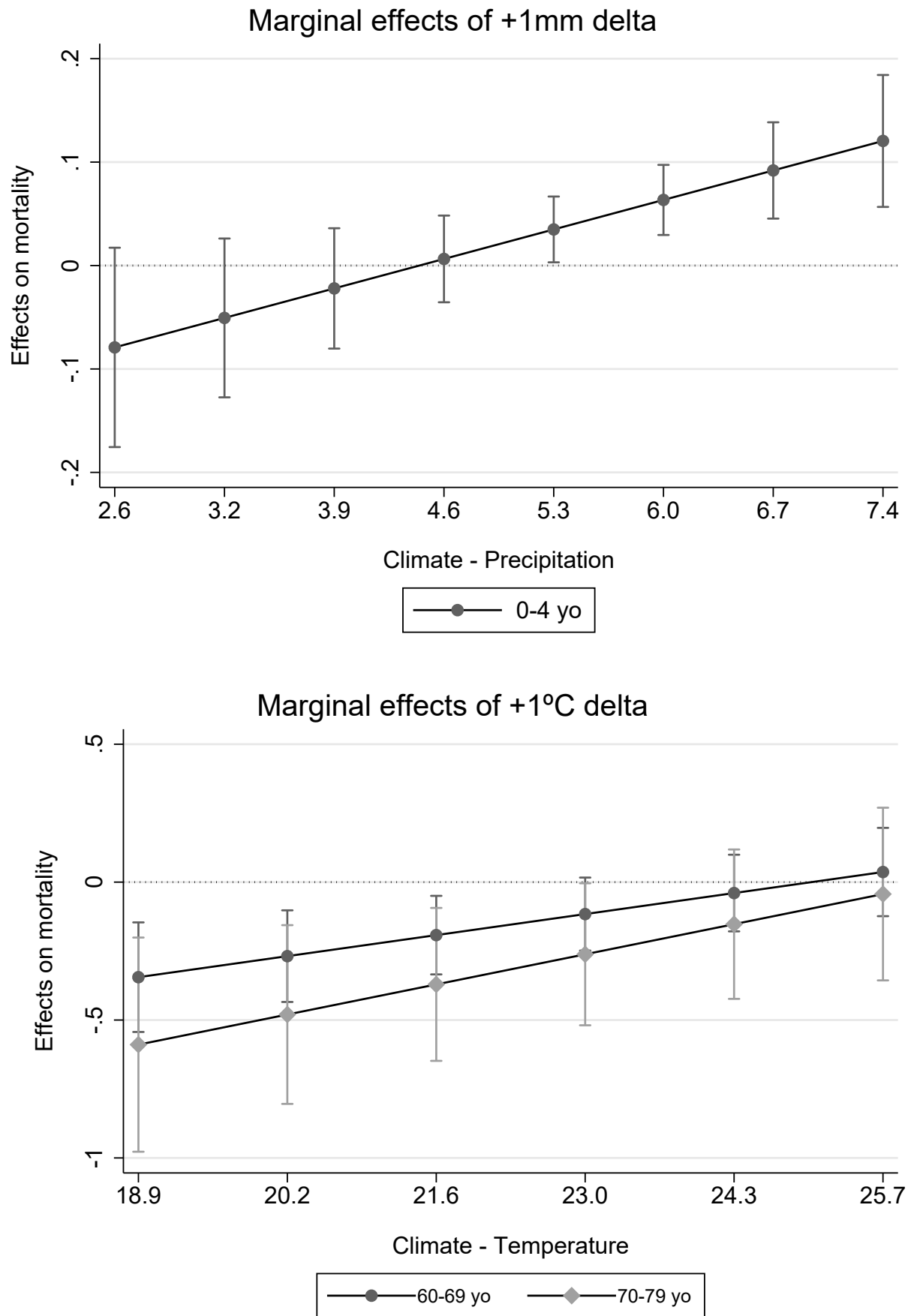

Notes: Top Figure shows marginal effects of $1 \mathrm{~mm}$ shock on mortality rates of children aged 0 to 4 years old. Bottom Figure shows marginal effects of $1{ }^{\circ} \mathrm{C}$ shock on mortality rates of adults aged 60 to 79 years old. We apply our preferred specification, which includes time fixed effects, city fixed effect and state clusters. All regressions are weighted by the average population of the city between 1980 and 2012 . 


\subsubsection{Heterogeneities}

As mentioned in the previous section, Brazil is a continental size country with great socioeconomic disparities ${ }^{3.3 .2}$ and many different climates (see Appendix Figures 3.4.4 and 3.4.5). So it is necessary to understand if weather impacts mortality these subgroups differently. We first do this test for demographic subgroups and then for regional subgroups. We do this only for children aged 0 to 4 as they were the most affected by weather in our main exercise.

\section{Demographic groups}

In this section we turn to our investigation of heterogeneous effects by demographic group. To that end, we use variables to represent earnings, education and infrastructure of municipalities in 1980. We use the variables in the first year of our sample so they will not be correlated to the mortality rates. We partition the sample in two using the median of earnings (rich/poor), infrastructure (high and low levels of water, sewage and electricity coverage) and education (high and low levels of education and education gap). These variables are defined in the Appendix Table 3.4.1 and summary statiscis in Table 3.2.2.

Table 3.3.4 presents the coefficient estimates on the effects of children aged 0 to 4 years old. Panel A presents the effects on those children that live in cities below the median for demographic variables and Panel B the effects on children that live in cities above the median. Figure 3.3.2 shows the calculated marginal effects of $1^{\circ} \mathrm{C}$ shocks above climate normals for cities with low and high levels of demographic variables.

Positive temperature shocks in the cold (warm) season reduce (increase) mortality rates in cities with low levels of infrastructure (water supply and electricity) and education. A shock of $1^{\circ} \mathrm{C}$ in the cold season reduce mortality rates by $0.8 / 100,000$ in cities with low education $(0.17 \%)$ and by $0.3 / 100,000$ in cities with low infrastructure $(0.07 \%)$ e. On the warm season, however, this same shock increase mortality rates by $0.3 / 100,000$ in cities with low electricity infrastructure $(0.07 \%)$. Cities with high levels of infrastructure an education are not affected by

3.3.2 Most of the countries GDP is generated by the Southeast, South and Midwest regions. 
temperature shocks.

Figure 3.3.3 shows the calculated marginal effects of $1 \mathrm{~mm}$ shocks above climate normals for cities with low and high levels of demographic variables. Positive precipitation shocks affect cities with low levels of water supply $(0.7 / 100,000$ $0.16 \%$ ) and cities with high levels of infrastructure (water supply and electricity) and education. A $1 \mathrm{~mm}$ shock in the rainy season increase mortality rates by $0.5 / 100,000$ in cities with high education levels $(0.08 \%)$ and by $0.5 / 100,000$ in cities with high levels of infrastructure $(0.08 \%)$. 
Table 3.3.4 - Impact of weather shocks on mortality rates for children aged 0 to 4 by demographic groups, Brazil 1980-2012

\begin{tabular}{|c|c|c|c|c|c|c|}
\hline & Earnings & Water & Electricity & Sewage & Education & Educ gap \\
\hline \multicolumn{7}{|l|}{ Panel A: Low } \\
\hline$\Delta T e m p$ & $\begin{array}{c}-1,154.98^{* *} \\
(552.36)\end{array}$ & $\begin{array}{l}-571.38^{* *} \\
(258.77)\end{array}$ & $\begin{array}{l}-686.96^{* *} \\
(280.67)\end{array}$ & $\begin{array}{c}201.17 \\
(228.19)\end{array}$ & $\begin{array}{c}-1,409.14^{* *} \\
(574.24)\end{array}$ & $\begin{array}{c}55.12 \\
(236.81)\end{array}$ \\
\hline$(\Delta T e m p) \cdot \bar{T}$ & $\begin{array}{c}44.65^{*} \\
(21.64)\end{array}$ & $\begin{array}{l}23.62^{* *} \\
(10.93)\end{array}$ & $\begin{array}{l}28.81^{* *} \\
(11.76)\end{array}$ & $\begin{array}{l}-10.33 \\
(10.97)\end{array}$ & $\begin{array}{l}54.69^{* *} \\
(22.57)\end{array}$ & $\begin{array}{c}-3.09 \\
(10.94)\end{array}$ \\
\hline$\Delta$ Prec & $\begin{array}{l}-92.48^{*} \\
(50.51)\end{array}$ & $\begin{array}{l}-47.66^{* *} \\
(22.85)\end{array}$ & $\begin{array}{l}-37.52 \\
(24.07)\end{array}$ & $\begin{array}{l}-42.68 \\
(40.29)\end{array}$ & $\begin{array}{c}-107.30 \\
(63.74)\end{array}$ & $\begin{array}{l}-19.42 \\
(20.65)\end{array}$ \\
\hline$(\Delta$ Prec $) \cdot \bar{P}$ & $\begin{array}{l}17.42^{*} \\
(8.95)\end{array}$ & $\begin{array}{l}11.05^{* *} \\
(4.23)\end{array}$ & $\begin{array}{c}7.78^{*} \\
(3.89)\end{array}$ & $\begin{array}{c}7.56 \\
(6.84)\end{array}$ & $\begin{array}{c}21.41^{*} \\
(12.11)\end{array}$ & $\begin{array}{c}6.25 \\
(3.63)\end{array}$ \\
\hline Obs & 21,698 & 19,229 & 20,755 & 8,915 & 22,010 & 23,844 \\
\hline Mean of dep. var. & 461.7 & 432.4 & 399.2 & 590.9 & 459.5 & 583.9 \\
\hline Temp. Inv. $\left({ }^{\mathrm{o}} \mathrm{C}\right)$ & 25.9 & 24.2 & 23.8 & 19.5 & 25.8 & 17.9 \\
\hline Prec. Inv. (mm) & 5.3 & 4.3 & 4.8 & 5.6 & 5.0 & 3.1 \\
\hline R-squared & 0.0164 & 0.0123 & 0.0154 & 0.0126 & 0.0223 & 0.0045 \\
\hline Year FE & Yes & Yes & Yes & Yes & Yes & Yes \\
\hline State cluster & Yes & Yes & Yes & Yes & Yes & Yes \\
\hline Municipal FE & Yes & Yes & Yes & Yes & Yes & Yes \\
\hline \multicolumn{7}{|l|}{ Panel B: High } \\
\hline$\Delta T e m p$ & $\begin{array}{c}142.37 \\
(174.36)\end{array}$ & $\begin{array}{l}352.03^{* *} \\
(167.20)\end{array}$ & $\begin{array}{l}352.03^{* *} \\
(170.41)\end{array}$ & $\begin{array}{c}343.93 \\
(324.91)\end{array}$ & $\begin{array}{c}239.34^{*} \\
(138.95)\end{array}$ & $\begin{array}{l}-928.40 \\
(579.68)\end{array}$ \\
\hline$(\Delta T e m p) \cdot \bar{T}$ & $\begin{array}{l}-7.19 \\
(8.21)\end{array}$ & $\begin{array}{l}-16.83^{* *} \\
(8.12)\end{array}$ & $\begin{array}{l}-16.81^{*} \\
(8.19)\end{array}$ & $\begin{array}{l}-15.34 \\
(15.06)\end{array}$ & $\begin{array}{l}-11.43^{*} \\
(6.56)\end{array}$ & $\begin{array}{c}35.30 \\
(23.09)\end{array}$ \\
\hline$\Delta$ Prec & $\begin{array}{l}-60.69^{*} \\
(33.92)\end{array}$ & $\begin{array}{l}-97.62^{*} \\
(48.32)\end{array}$ & $\begin{array}{l}-101.11^{* *} \\
(45.98)\end{array}$ & $\begin{array}{l}-39.10 \\
(54.72)\end{array}$ & $\begin{array}{l}-42.96^{*} \\
(21.10)\end{array}$ & $\begin{array}{l}-123.42^{* *} \\
(56.75)\end{array}$ \\
\hline$(\Delta$ Prec $) \cdot \bar{P}$ & $\begin{array}{l}13.35^{*} \\
(6.49)\end{array}$ & $\begin{array}{l}20.16^{* *} \\
(8.85)\end{array}$ & $\begin{array}{l}21.44^{* *} \\
(8.55)\end{array}$ & $\begin{array}{c}10.65 \\
(10.82)\end{array}$ & $\begin{array}{l}9.89^{* *} \\
(3.71)\end{array}$ & $\begin{array}{c}23.74^{*} \\
(13.17)\end{array}$ \\
\hline Obs & 23,841 & 21,836 & 24,782 & 9,105 & 23,529 & 21,695 \\
\hline Mean of dep. var. & 595.3 & 630.7 & 626.7 & 617.6 & 602.7 & 506.7 \\
\hline Temp. Inv. $\left({ }^{\mathrm{o}} \mathrm{C}\right)$ & 19.8 & 20.9 & 20.9 & 22.4 & 20.9 & 26.3 \\
\hline Prec. Inv. (mm) & 4.5 & 4.8 & 4.7 & 3.7 & 4.3 & 5.2 \\
\hline R-squared & 0.0068 & 0.0167 & 0.0172 & 0.0136 & 0.0110 & 0.0144 \\
\hline Year FE & Yes & Yes & Yes & Yes & Yes & Yes \\
\hline State cluster & Yes & Yes & Yes & Yes & Yes & Yes \\
\hline Municipal FE & Yes & Yes & Yes & Yes & Yes & Yes \\
\hline
\end{tabular}

Notes: Table applies our preferred specification, which includes time fixed effects, city fixed effect and state clusters, to the dependent variable of children aged 0 to 4 years old. All regressions are weighted by the average population of the city between 1980 and 2012 . We separate the effects in two by the median of the following demographic groups: Earnings, Water, Electricity, Sewage, Education and Education Gap. These variables are defined in Table 3.4.1. Panel A presents the effects on children aged 0 to 4 that live in cities below the median for these variables and Panel B the effects on children aged 0 to 4 that live in cities above the median. Weather variables used are temperature and precipitation deviations from climate normals $(\Delta T e m p, \Delta$ Prec $)$ and its interactions with climate $((\Delta$ Temp $) \cdot \bar{T},(\Delta P r e c) \cdot \bar{P})$. Temp inv. $\left({ }^{\circ} \mathrm{C}\right)$ and Prec inv. $(\mathrm{mm})$ are, respectively, the temperature and precipitation inflection points considering $\Delta T e m p=0$ and $\Delta P r e c=0$ (n.a. means not applicable, as the linear term does not present signal inversion). 
Figure 3.3.2 - Marginal effects of $1^{\circ} \mathrm{C}$ shock on children mortality rates, Brazil 1980-2012
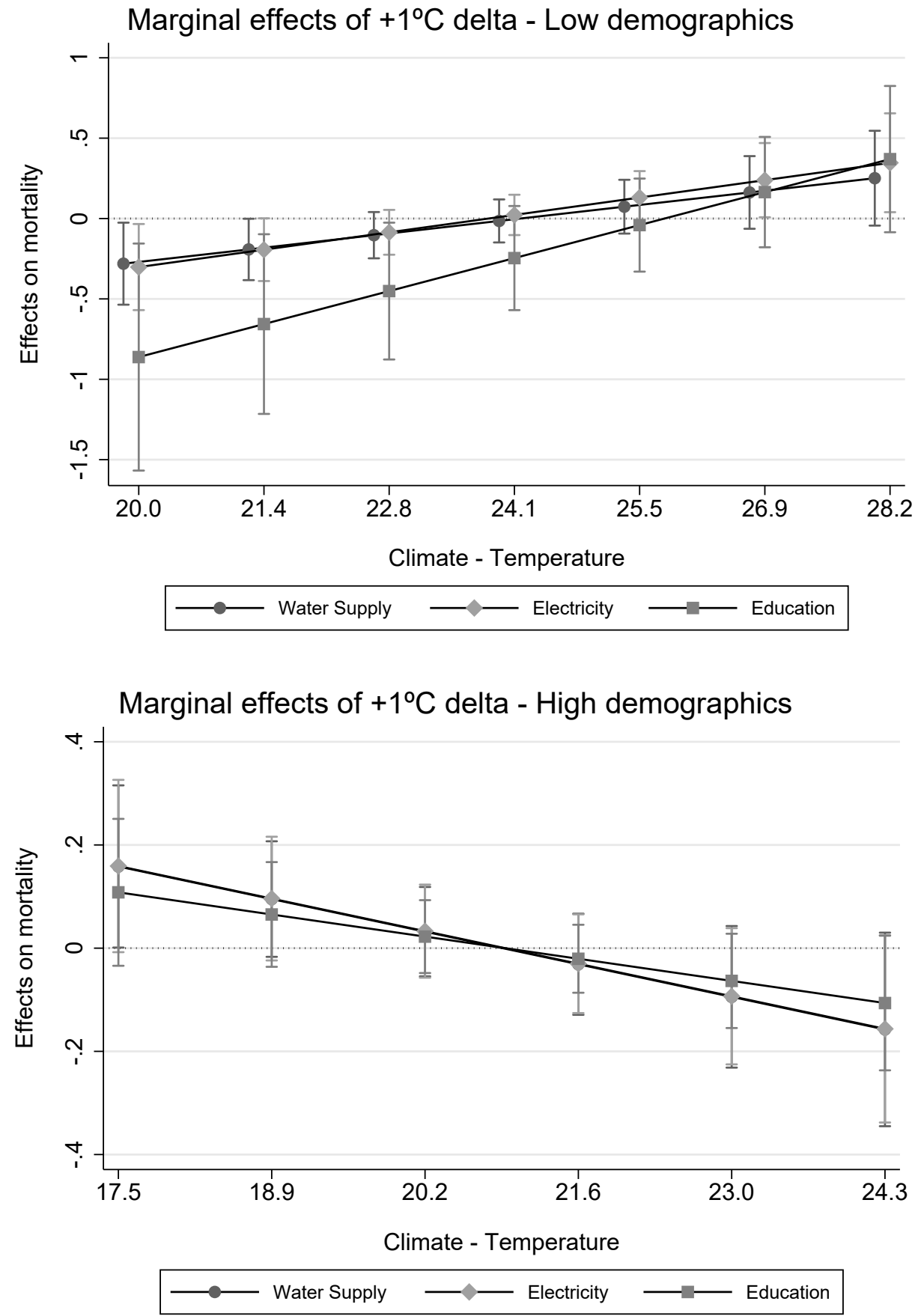

Notes: Figure shows marginal effects of $1^{\circ} \mathrm{C}$ temperature deviation from climate normal on mortality rates of children aged 0 to 4 by demographic groups. Top figure depicts the effects for cities with low levels of water supply, electricity and education. Bottom figure depicts these effects for cities with high levels of water supply, electricity and education. We apply our preferred specification, which includes time fixed effects, city fixed effect and state clusters. All regressions are weighted by the average population of the city between 1980 and 2012 . 
Figure 3.3.3 - Marginal effects of 1mm shock on children mortality rates, Brazil 1980-2012
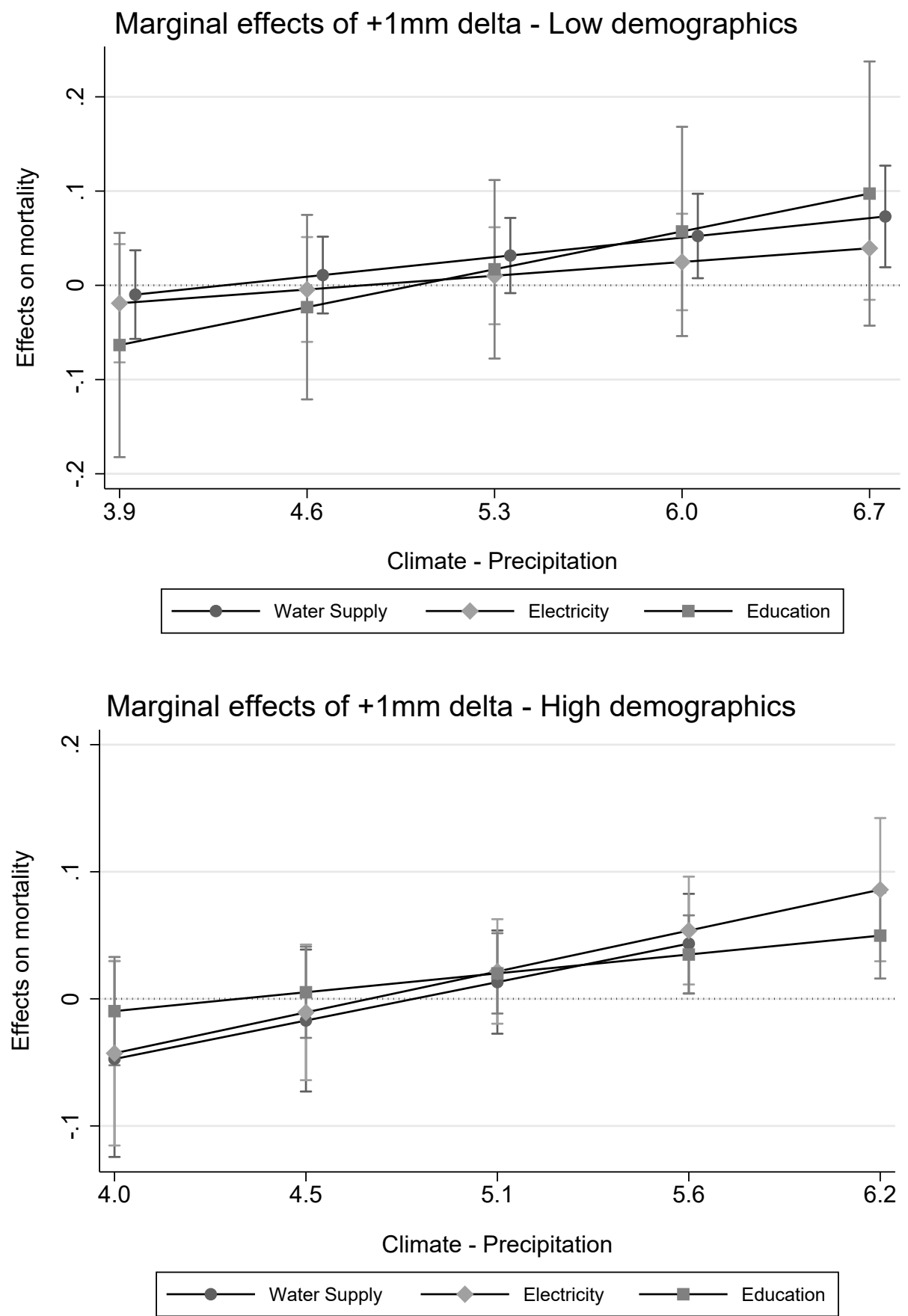

Notes: Figure shows marginal effects of $1 \mathrm{~mm}$ precipitation deviation from climate normal on mortality rates of children aged 0 to 4 by demographic groups. Top figure depicts the effects for cities with low levels of water supply, electricity and education. Bottom figure depicts these effects for cities with high levels of water supply, electricity and education. We apply our preferred specification, which includes time fixed effects, city fixed effect and state clusters. All regressions are weighted by the average population of the city between 1980 and 2012 . 


\section{Macro-region}

In this section we ask if temperature shocks have different effects on mortality rates across macro-regions. We run our same preferred specification from the previous sections for all five Brazilian macro-regions. Results are presented in Table 3.3.5 and show heterogeneous effects for all macro-regions. Temperature and precipitation inversions occur at different points for each region, and they are related to the climate of the region. The North region, for example, is hot and humid and presents inversion points at $32^{\circ} \mathrm{C}$ and $6 \mathrm{~mm}$. The coldest region in the country is the South region and presents the lowest inversion point in terms of temperature $\left(12^{\circ} \mathrm{C}\right)$.

Children aged 0 to 4 seem to be more affected by weather variations in the Northeast and Midwest regions (Figure 3.3.4). Positive temperature shocks in the cold season reduce children mortality rates by $0.2 / 100,000$ in the Midwest region $(0.04 \%)$ and by $0.7 / 100,000$ in the Northeast region $(0.13 \%)$. On the warm season, positive temperature shocks increase mortality by $0.3 / 100,000$ only in the Midwest region $(0.06 \%)$. A $1 \mathrm{~mm}$ positive precipitation shock in the dry season reduce mortality rates by $0.2 / 100,000$ in the Northeast region $(0.04 \%)$ which speaks directly with the work of Rocha e Soares (2015) that finds that increases in rainfall in the Brazilian semiarid (Northeast region) reduced infant mortality rates. 
Table 3.3.5 - Impact of weather shocks on mortality rates for children aged 0 to 4 by macro-region, Brazil 1980-2012

\begin{tabular}{lccccc}
\hline \hline & & & & & \\
& Southeast & South & Midwest & Northeast & North \\
\hline$\Delta$ Temp & -100.56 & -21.71 & $-1,053.38^{* *}$ & $-1,958.67^{*}$ & 753.69 \\
& $(122.96)$ & $(70.00)$ & $(281.21)$ & $(1,015.91)$ & $(5,000.93)$ \\
$(\Delta$ Temp $) . \bar{T}$ & 4.98 & 1.87 & $43.62^{* *}$ & 74.30 & -24.26 \\
& $(5.32)$ & $(3.59)$ & $(11.36)$ & $(40.32)$ & $(183.53)$ \\
$\Delta$ Prec & & & & & \\
& 10.51 & 63.86 & $289.53^{*}$ & $-155.54^{*}$ & 14.81 \\
& $(28.01)$ & $(22.13)$ & $(112.30)$ & $(71.64)$ & $(60.24)$ \\
$\Delta$ Prec).P & & & & & \\
& 0.59 & -10.25 & $-69.67^{*}$ & $34.71^{* *}$ & -2.48 \\
Obs & $(4.66)$ & $(5.14)$ & $(26.65)$ & $(14.94)$ & $(9.14)$ \\
Mean of dep. var. & 15,288 & 7,601 & 3,402 & 16,060 & 3,188 \\
Temp. Inv. ( $\left.{ }^{\circ} \mathrm{C}\right)$ & 596.7 & 498.6 & 476.6 & 556.1 & 545.0 \\
Prec. Inv. $(\mathrm{mm})$ & 20.2 & 11.6 & 24.2 & 26.4 & 31.1 \\
R-squared & n.a. & 6.2 & 4.2 & 4.5 & 6.0 \\
Year FE & 0.0032 & 0.0040 & 0.0401 & 0.0333 & 0.0071 \\
State cluster & Yes & Yes & Yes & Yes & Yes \\
Municipal FE & Yes & Yes & Yes & Yes & Yes \\
\hline \hline
\end{tabular}

Notes: Table applies our preferred specification, which includes time fixed effects, city fixed effect and state clusters, to the dependent variable of children aged 0 to 4 years old. All regressions are weighted by the average population of the city between 1980 and 2012. We calculate the effects for each Brazilian macro-region: Southeast, South, Midwest, Northeast and North. Weather variables used are temperature and precipitation deviations from climate normals $(\Delta$ Temp, $\Delta$ Prec $)$ and its interactions with climate $((\Delta$ Temp $) \cdot \bar{T},(\Delta$ Prec $) \cdot \bar{P})$. Temp inv. $\left({ }^{\circ} \mathrm{C}\right)$ and Prec inv. $(\mathrm{mm})$ are, respectively, the temperature and precipitation inflection points considering $\Delta T e m p=0$ and $\Delta P r e c=0$ (n.a. means not applicable, as the linear term does not present signal inversion). 
Figure 3.3.4 - Marginal effects on mortality rates of children aged 0 to 4 for selected regions, Brazil 1980-2012
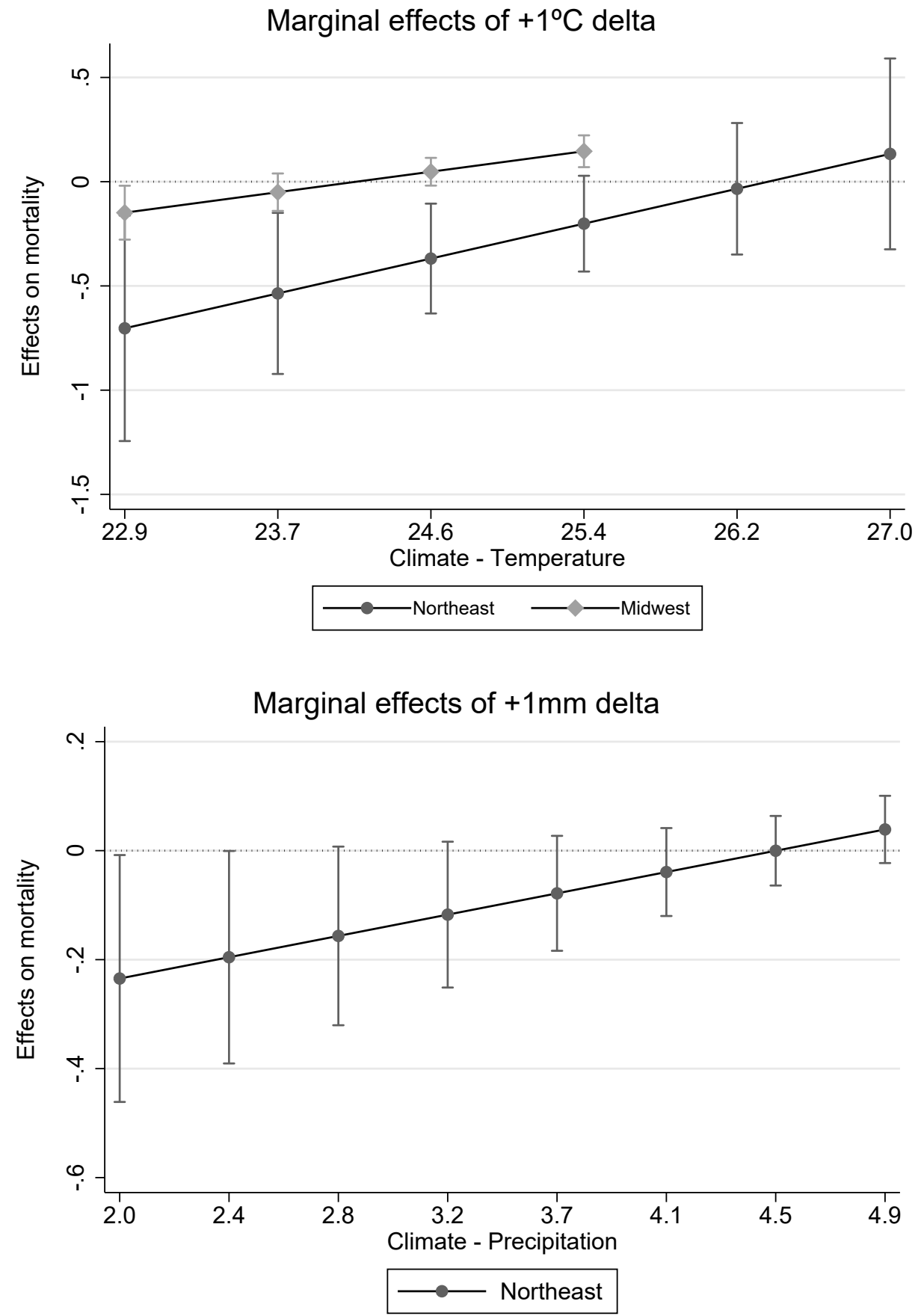

Notes: Top Figure shows marginal effects of $1^{\circ} \mathrm{C}$ shock on mortality rates of children aged 0 to 4 in the Northeast and Midwest regions. Bottom Figure shows marginal effects of $1 \mathrm{~mm}$ shock on mortality rates of children aged 0 to 4 years old in the Northeast region. We apply our preferred specification, which includes time fixed effects, city fixed effect and state clusters. All regressions are weighted by the average population of the city between 1980 and 2012 . 


\subsection{Final remarks}

In this paper we ask the question whether weather shocks affect mortality rates in Brazil. To answer this question, we create an annual panel data of 2198 Brazilian municipalities and 33 years, from 1980 to 2012, with temperature and precipitation information.

The first contribution of the paper is to produce an original database to understand the relation between weather and mortality at national level. Previous studies focused on mortality in São Paulo city - Son et al. (2016) and Gouveia, Hajat e Armstrong (2003) - or in agriculture yields and were limited to the Brazilian semiarid (Northeast region) - Motta et al. (2011) and Sun, Li e Ward (2007). Children aged 0 to 4 are the most affected by weather variations and have their mortality rates increase by $0.02 \%$ with positive precipitation shocks in the rainy season.

Our second contribution is the identification of different heterogeneities of the weather effects on children mortality rates, as they are more susceptible to such variations (Xu et al. (2012)). Another contribution is to shed light in the weather-health relationship in developing countries (Geruso e Spears (2018)) using a continental size developing country with great climate variability. We show that positive temperature shocks in the cold season reduce children mortality rates in cities with low levels of infrastructure and educational levels. Precipitation shocks, on the other hand, impacts children in cities with both low and high levels of infrastructure and education. This result dialogues with a literature that finds impacts of humidity and mortality (Geruso e Spears (2018), Zhang et al. (2014) and Barreca (2012)) and also with the majority of the works that focus on temperature in their empirical models (Hanlon, Hansen e Kantor (2020), Burgess et al. (2017), Barreca et al. (2016), Barreca et al. (2015), Deschenes e Greenstone (2011) and Huynen et al. (2001)). Still, the correlation between precipitation and humidity and its impacts on health needs to be better discussed. Also, we present evidence that the Midwest and Northeast regions are the most affected by weather shocks. The Northeast region see a reduction in children mortality rates with positive 
temperature and precipitation shocks, respectively, in the cold and dry seasons Rocha e Soares (2015). The Midwest region is impacted by temperature shocks both in the cold and warm seasons.

Our study, however, has one important limitation, which is the lack of finer weather data. The spatial resolution of the grids is $30 \mathrm{~km} x 30 \mathrm{~km}$. In this sense, the limited variation of temperature might have affected the uncertainty bands of the estimates. 
Appendix $C$ 


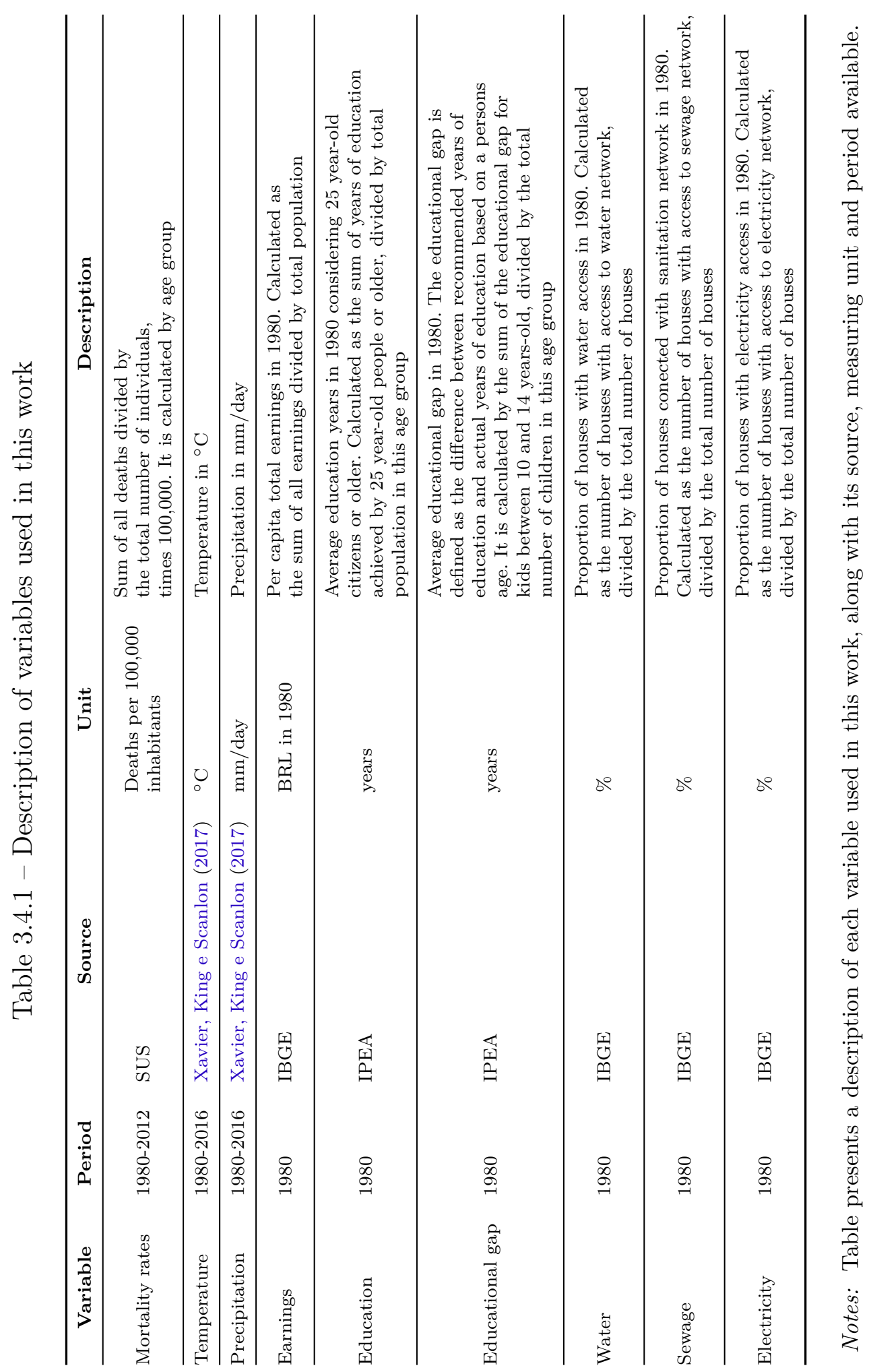


Additional mortality statistics 


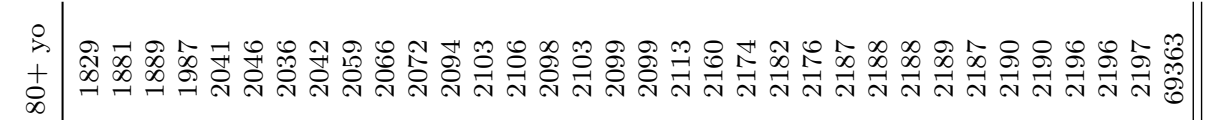

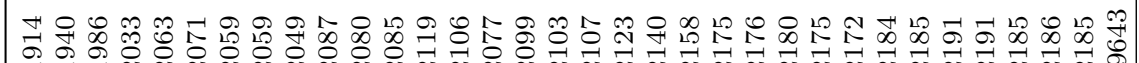

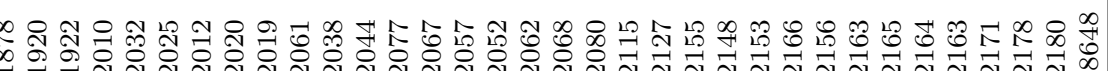

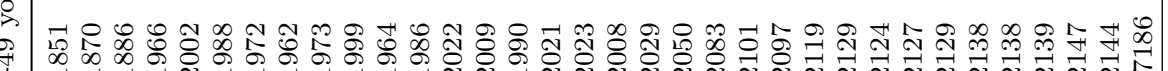

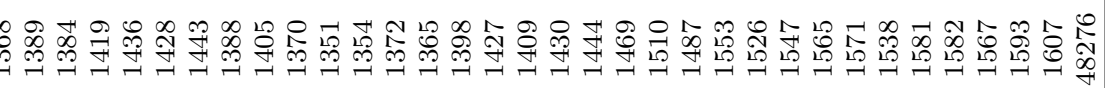

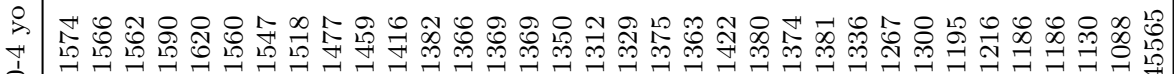

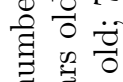




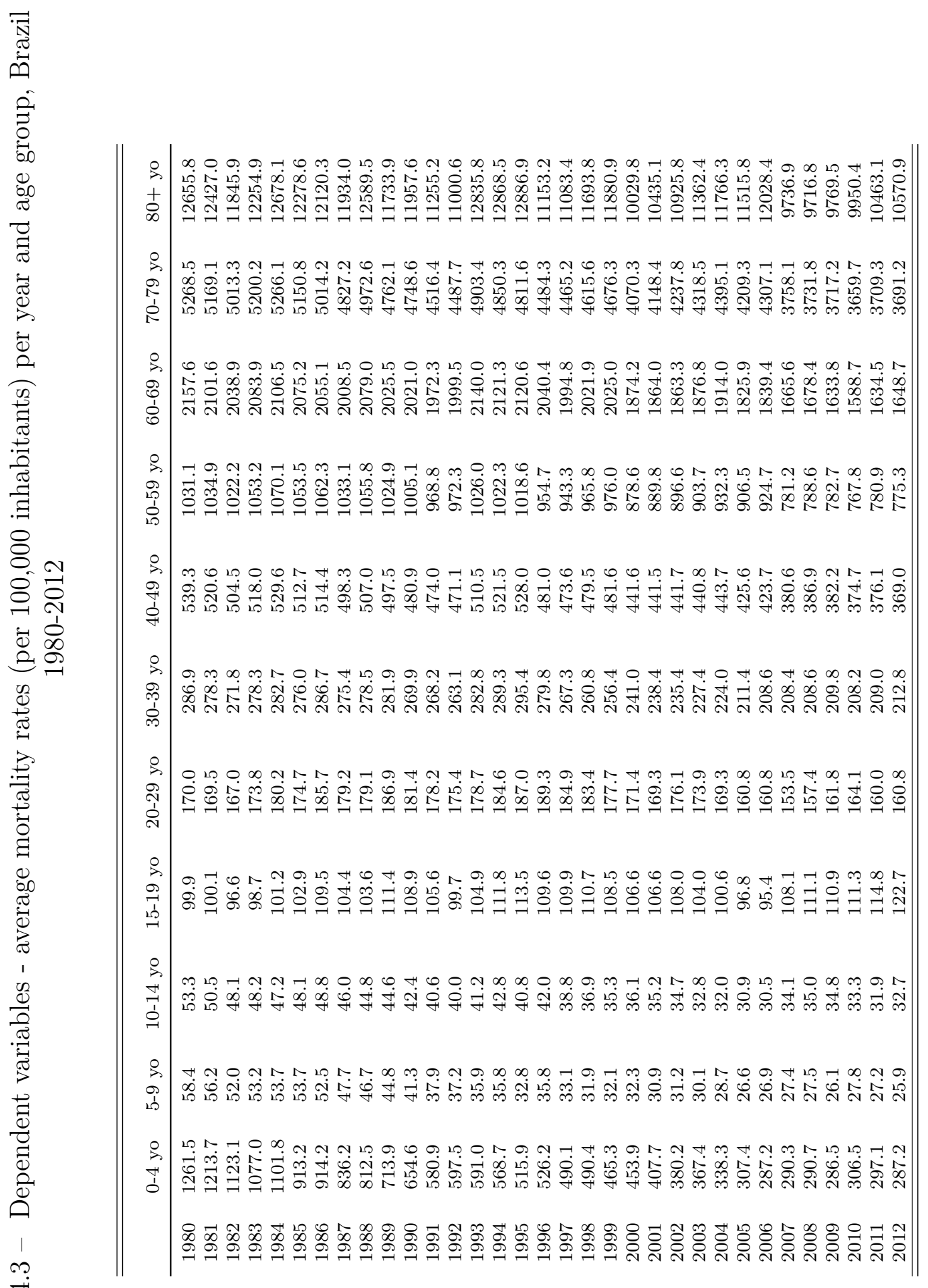

108

흥 웅

क् 8

Ð

ㅎํ

०

붕

50

0 은

.0

造

낭

퓽 웅

우

$\because \ddot{0}$

过

मे

तु

ติ

훙

을

b

$\left.\infty_{-\infty}^{\infty}\right)^{\circ}$

고

ఫี 용

훙 잉

¿ 00

屯ै छٓ

:

至

氙

芯

¿

$\exists$

mo

엉의

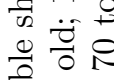

䨌

峦

$\frac{0}{\frac{0}{6}}$ 


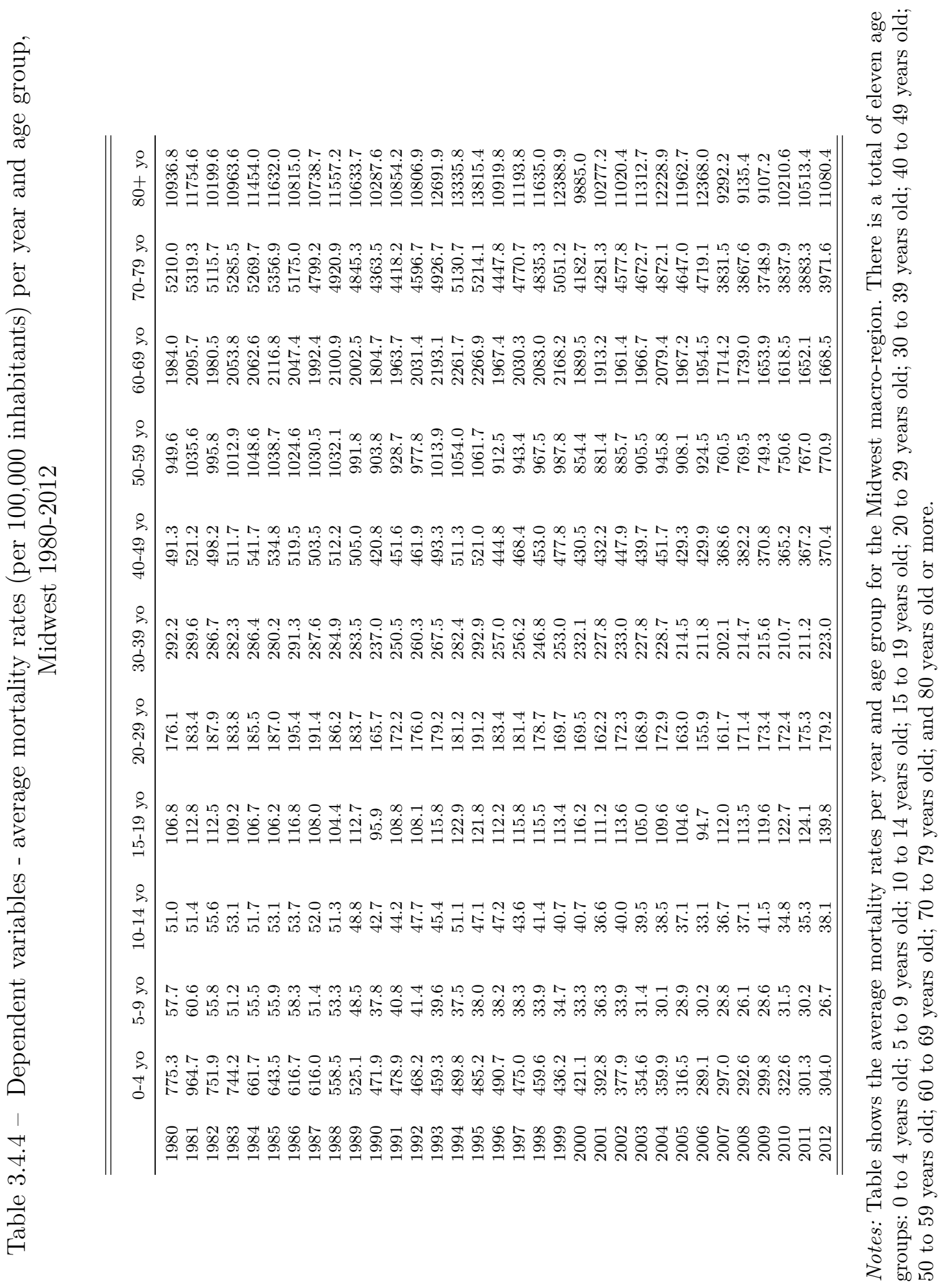




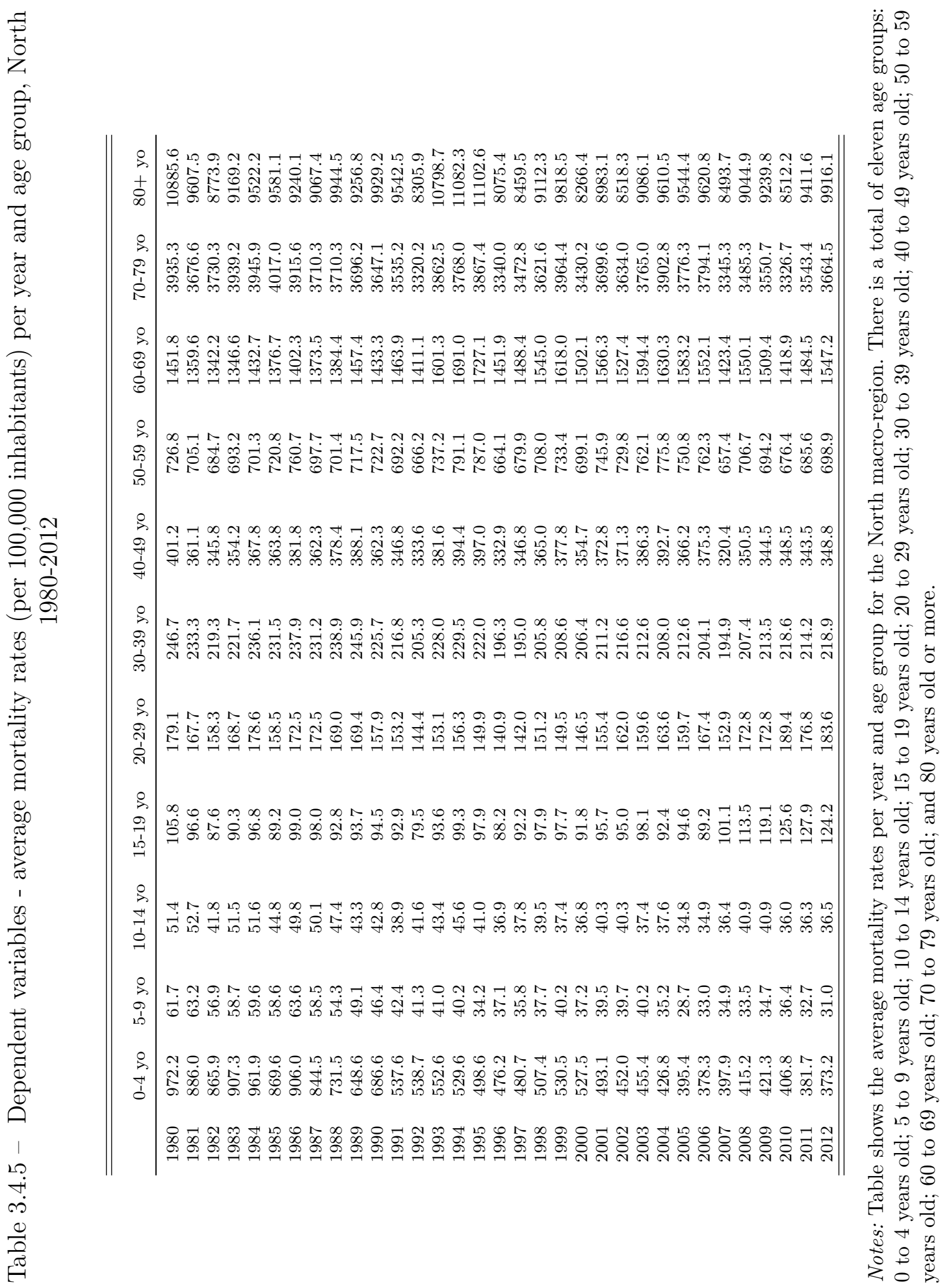




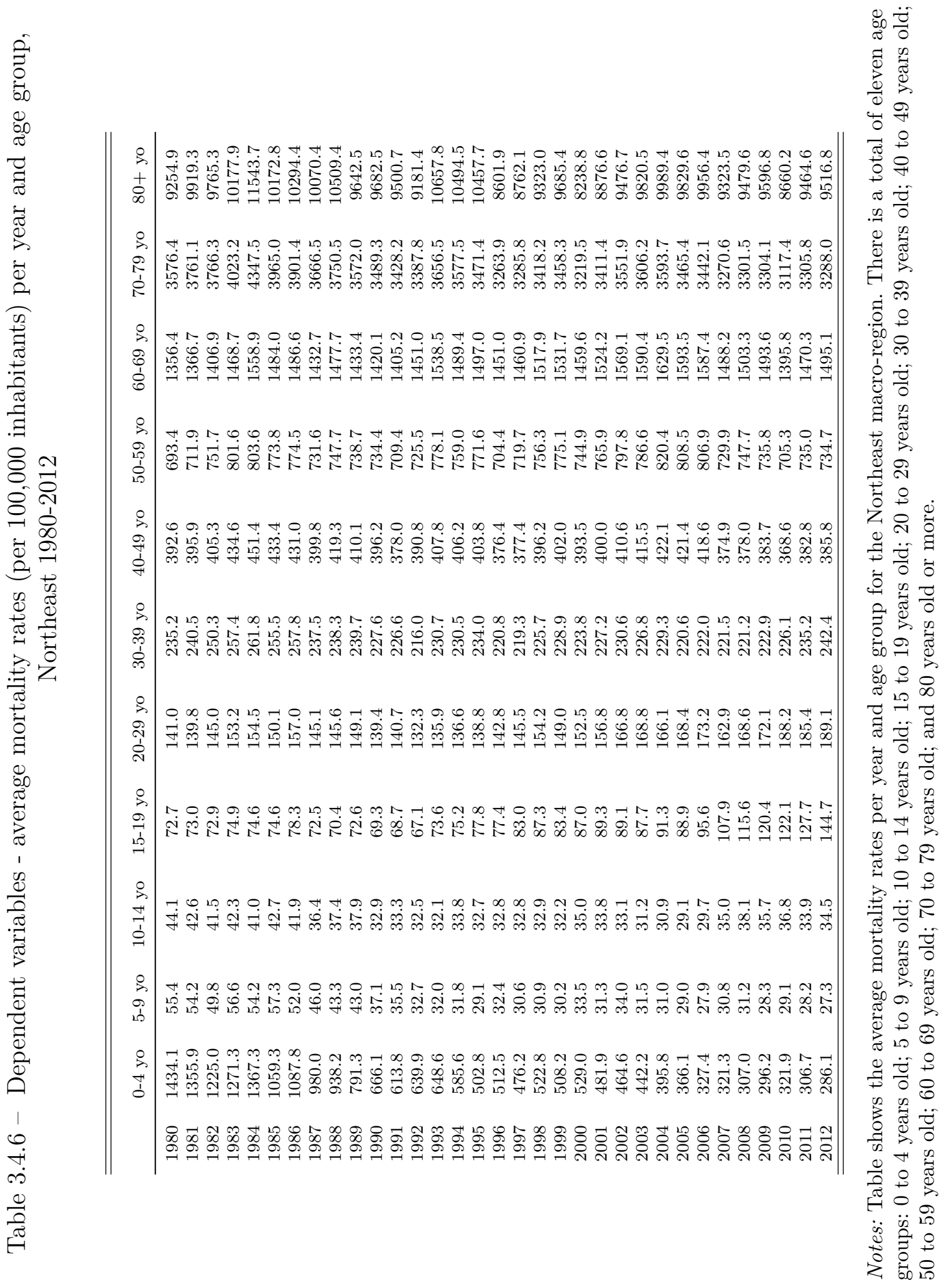




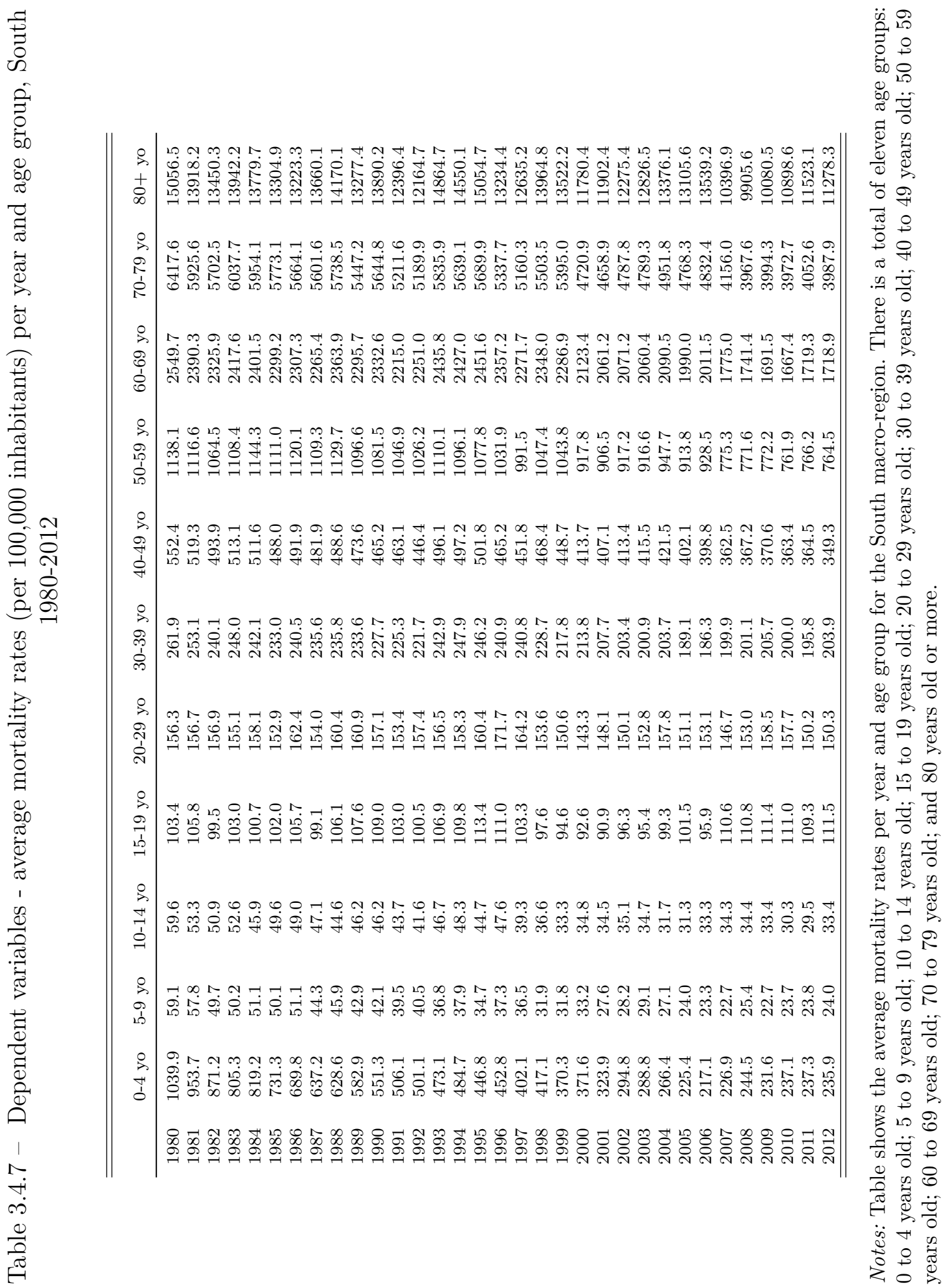




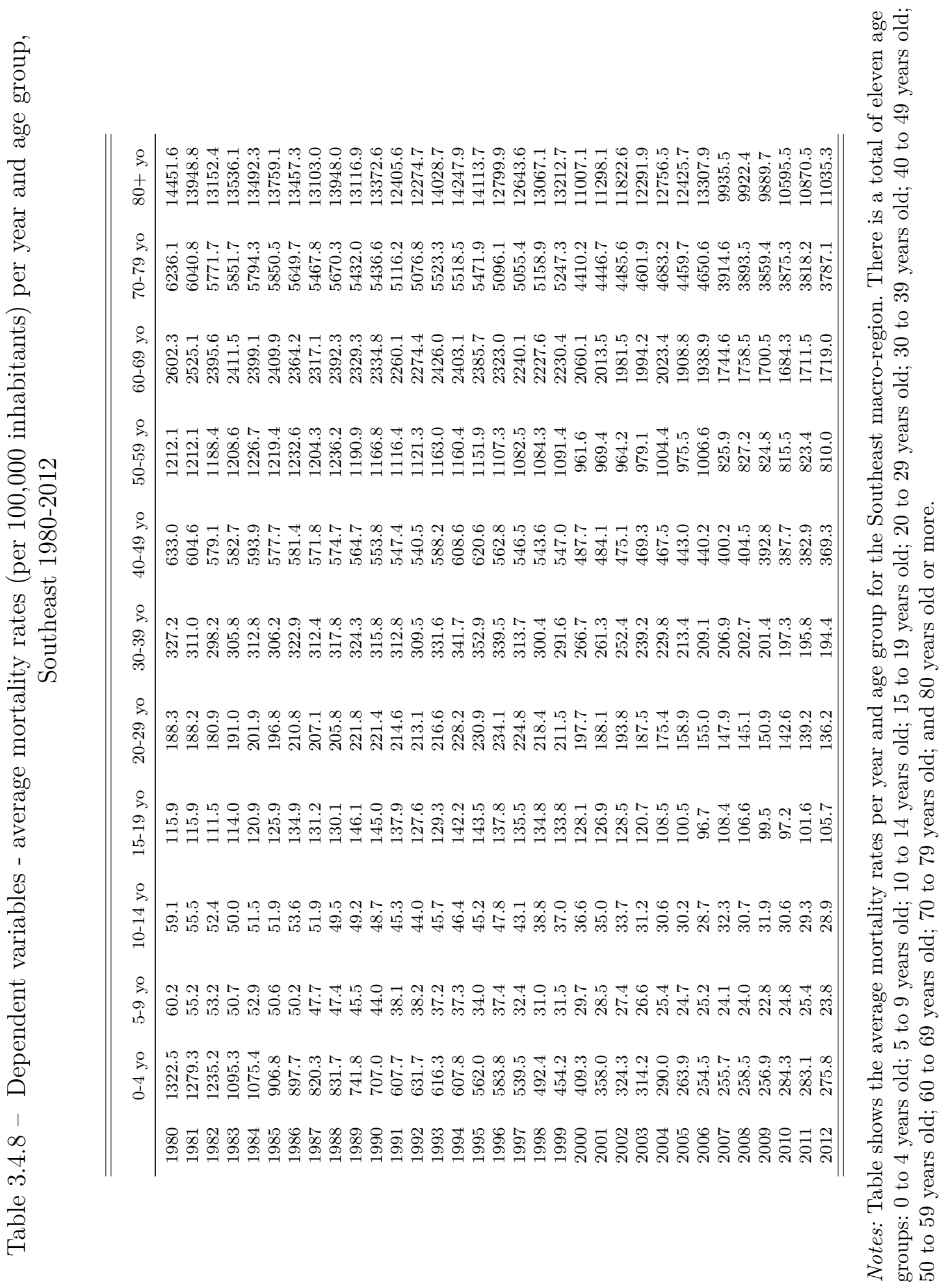


Additional weather statistics 
Figure 3.4.1 - Climate temperature distribution $\left({ }^{\circ} \mathrm{C}\right)$ by macro-region, Brazil $1980-2012$

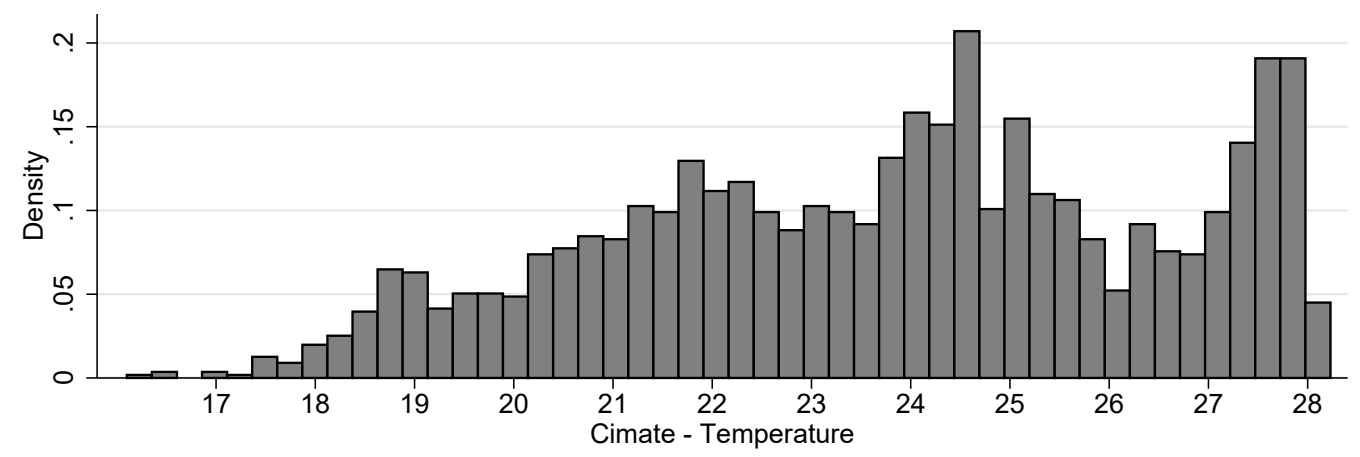

Brazil
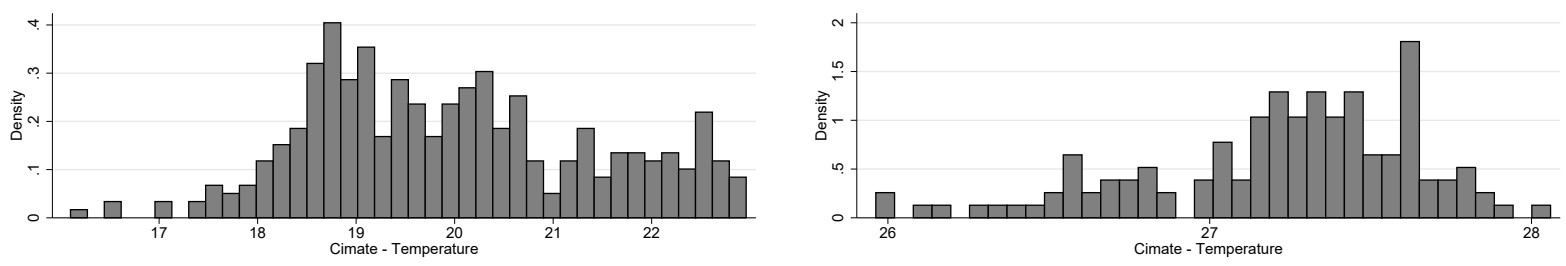

South and North Regions
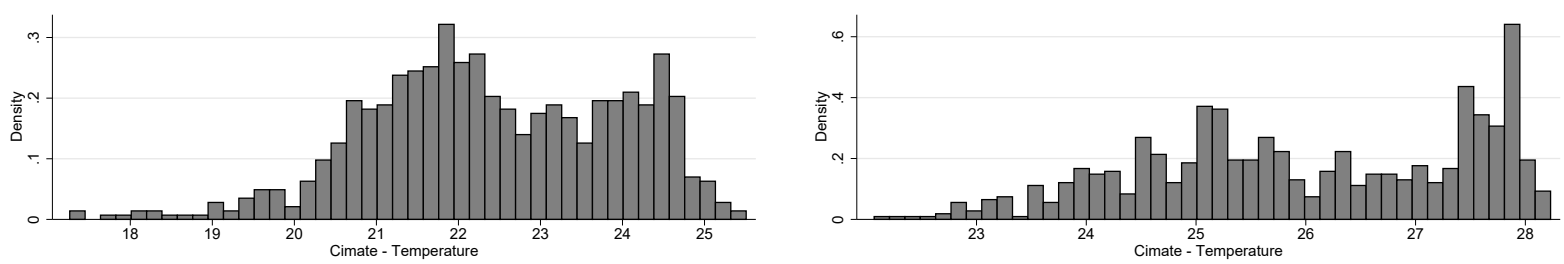

Southeast and Northeast Regions

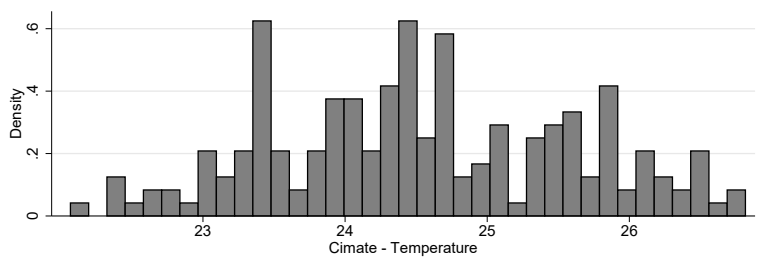

Midwest Region

Notes: Figures depict climate temperature distributions $\left(\right.$ in $\left.{ }^{\circ} \mathrm{C}\right)$ for Brazil and by macro-regions.

These are the distributions used to calculate marginal effects in Section 1.4. 
Figure 3.4.2 - Climate precipitation distribution (mm/day) by macro-region, Brazil 1980-2012

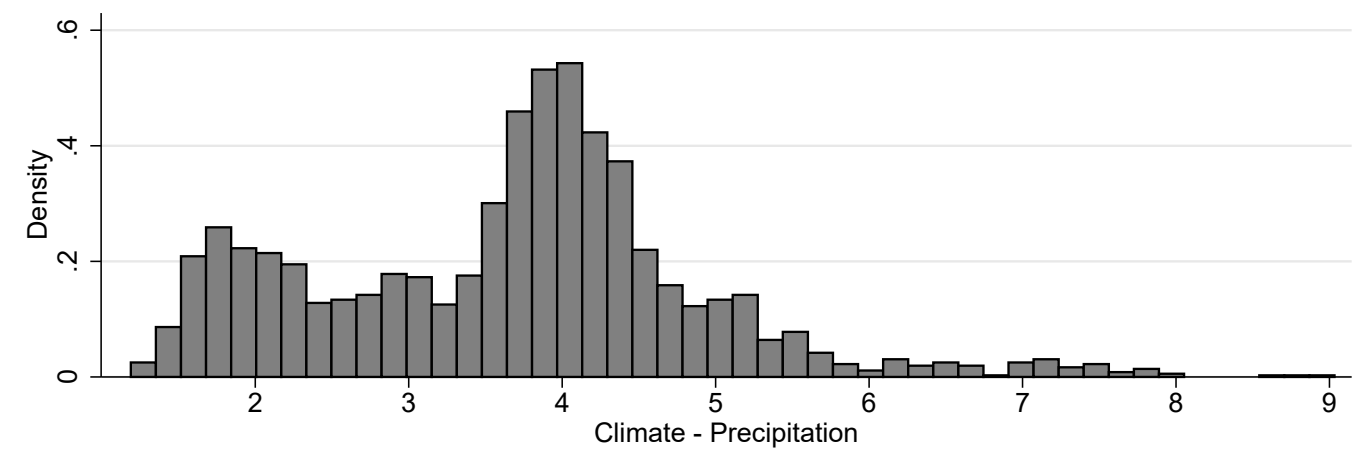

Brazil
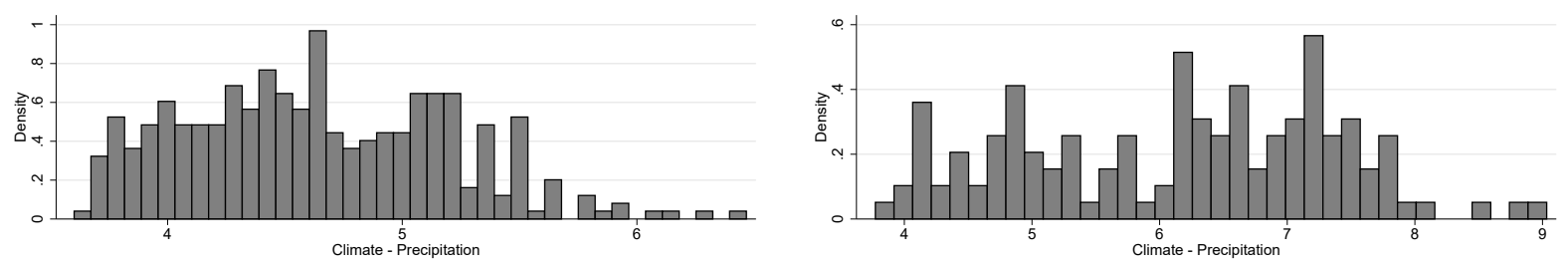

South and North Regions
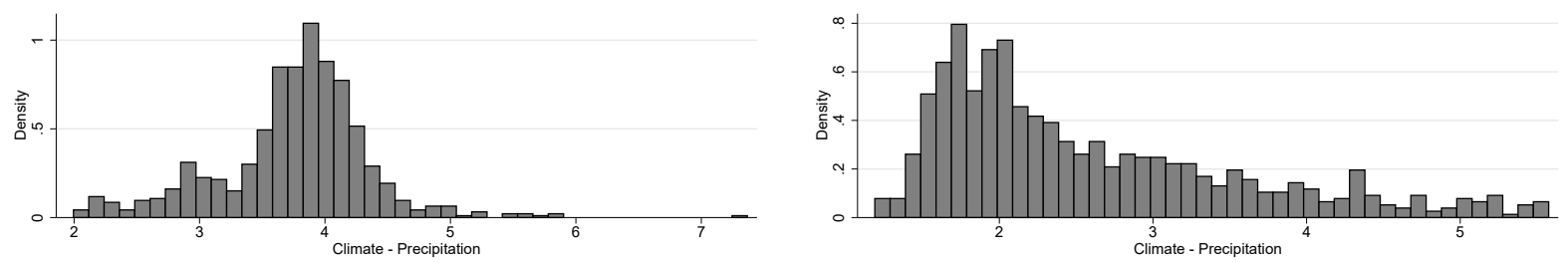

Southeast and Northeast Regions

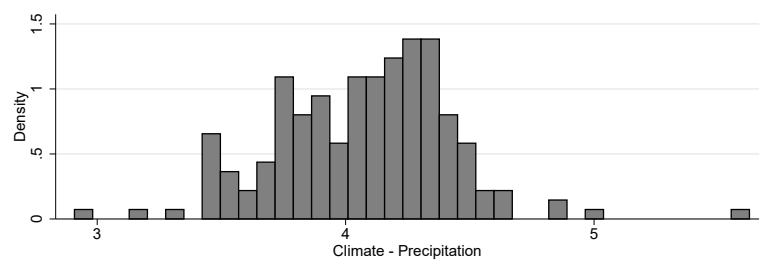

Midwest Region

Notes: Figures depict climate precipitation distributions (in $\mathrm{mm} /$ day) for Brazil and by macroregions. These are the distributions used to calculate marginal effects in Section 1.4. 
Figure 3.4.3 - Weather and climate averages by region and year, Brazil 1980-2012
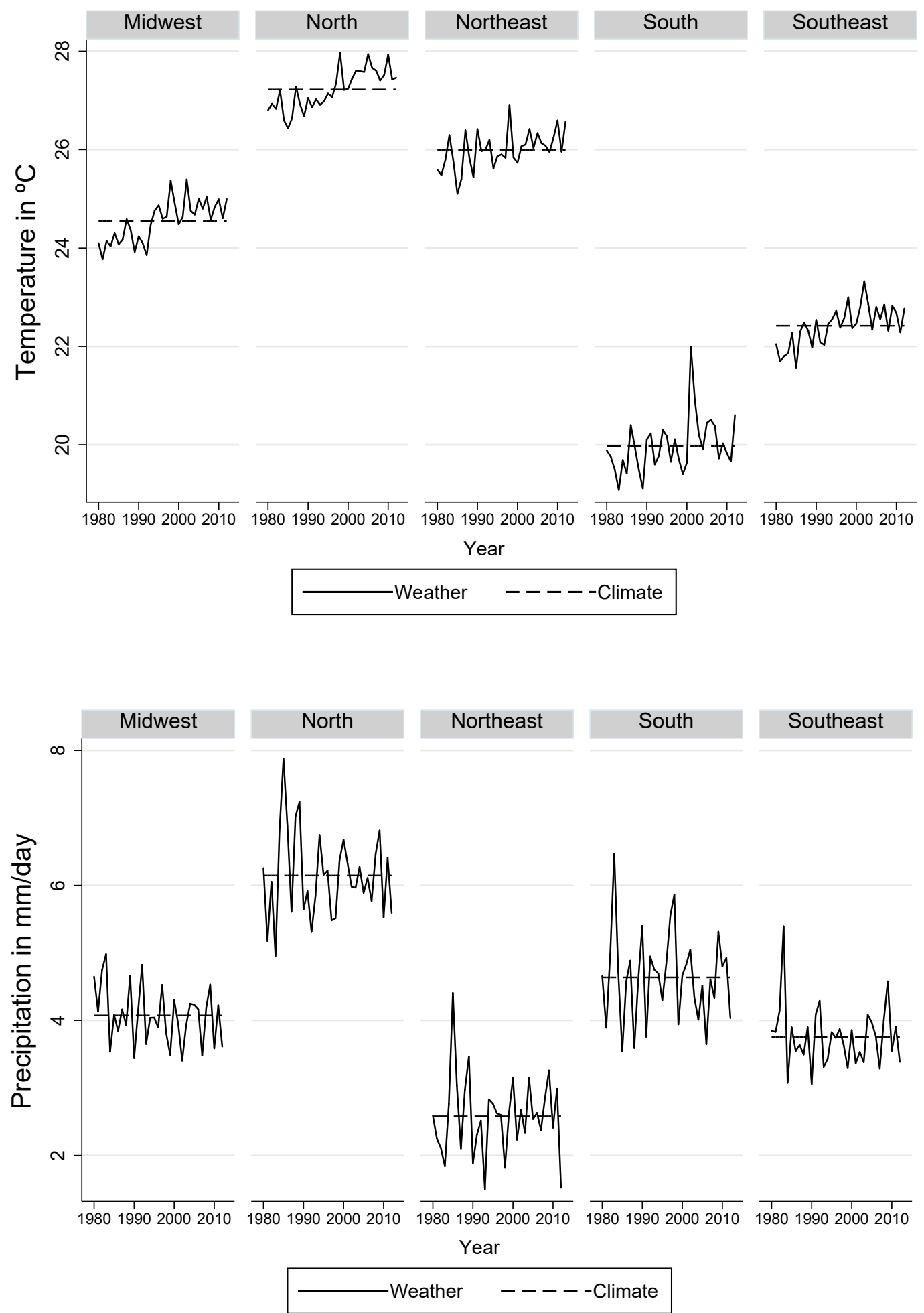

Notes: Figure shows temperature $\left(\right.$ in ${ }^{\circ} \mathrm{C}$ ) and precipitation (in $\mathrm{mm} /$ day) averages by region and year between 1980 and 2012 . 
Figure 3.4.4 - Climate temperature distribution in ${ }^{\circ} \mathrm{C}$, Brazil 1980-2016

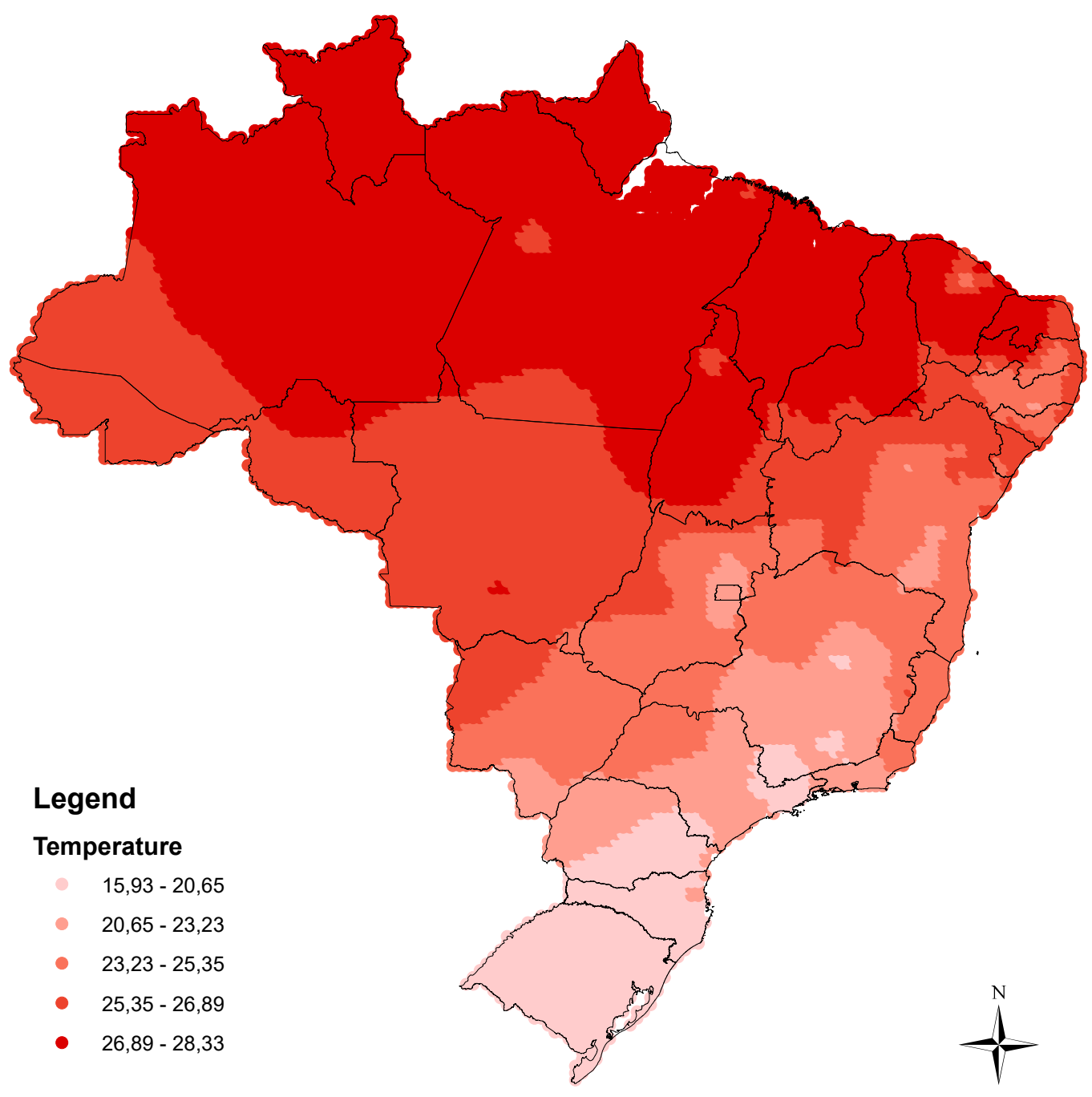

Notes: The map plots the 1980-2016 temperature average for the 162x168 latitude-longitude grid extracted from Xavier, King e Scanlon (2017). 
Figure 3.4.5 - Climate precipitation distribution in mm/day, Brazil 1980-2015

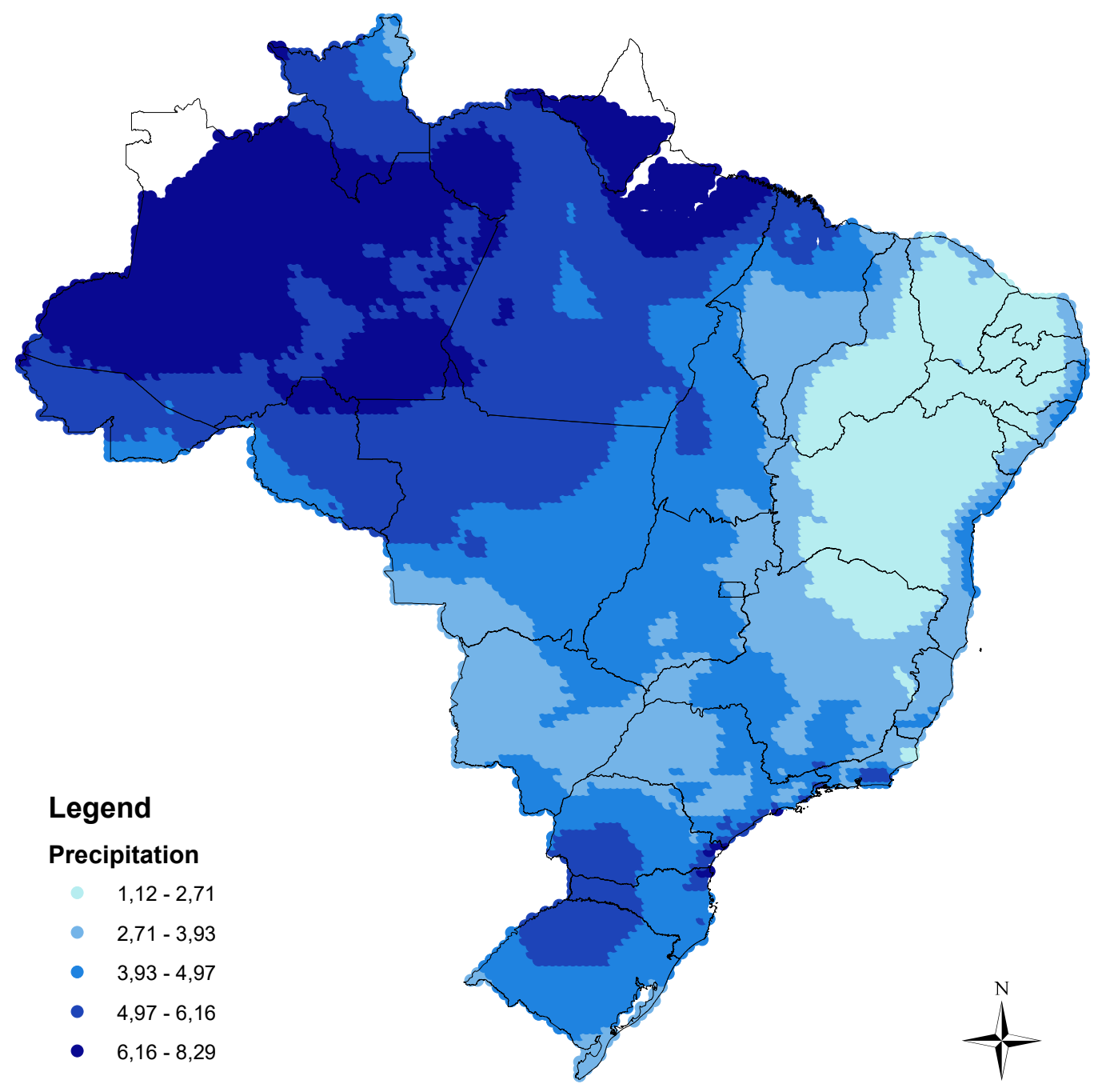

Notes: The map plots the 1980-2015 precipitation average for the 162x168 latitude-longitude grid extracted from Xavier, King e Scanlon (2017). 



\section{REFERENCES}

ADHVARYU, A.; KALA, N.; NYSHADHAM, A. The Light and the Heat: Productivity Co-benefits of Energy-saving Technology. Review of Economics and Statistics, v. 0034-6535, p. 1-36, 2020.

ARAUJO, M. B.; NAIMI, B. Spread of SARS-CoV-2 Coronavirus likely to be constrained by climate. medRxiv, p. 2020.03.12.20034728, 2020 .

ARAÚJO, P. H. C. et al. An analysis of the impact of climate change on agricultural productivity of Northeast of Brazil. Rev. Econ. NE, v. 45, n. 3, p. 46-57, 2014.

ASSAD, E. D. et al. Impacts of climate change on the agricultural zoning of climate risk for cotton cultivation in Brazil. Pesq. agropec. bras., v. 48, n. 1, p. 1-8, 2013.

ASSAD, E. D. et al. Climatic changes impact in agroclimatic zonning of coffee in Brazil. Pesq. agropec. bras., v. 39, n. 11, p. 1057-1064, 2004 .

BANERJEE, R.; MAHARAJ, R. Heat, infant mortality, and adaptation: Evidence from india. Journal of Development Economics, Elsevier, v. 143, p. 102378, 2020.

BARBARISI, B. F. et al. Efeito das mudanças climáticas sobre a aptidão climática para cana-de-açúcar no estado de Goiás. In: $X V$ Congresso Brasileiro de Agrometeorologia. [S.l.: s.n.], 2007. p. 5.

BARRECA, A. et al. Convergence in adaptation to climate change: Evidence from high temperatures and mortality, 1900-2004. American Economic Review, v. 105, n. 5, p. 247-251, 2015. ISSN 00028282.

BARRECA, A. et al. Adapting to climate change: The remarkable decline in the US temperature-mortality relationship over the Twentieth Century. Journal of Political Economy, v. 124, n. 1, p. 105-159, 2016. ISSN 1537534X. 
BARRECA, A. I. Climate change, humidity, and mortality in the United States. Journal of Environmental Economics and Management, Elsevier, v. 63, n. 1, p. 19-34, 2012. ISSN 00950696. Disponível em: <http://dx.doi.org/10.1016/j.jeem.2011.07.004> .

BASU, R.; SAMET, J. M. Relation between elevated ambient temperature and mortality: A review of the epidemiologic evidence. Epidemiologic Reviews, v. 24, n. 2, p. 190-202, 2002. ISSN 0193936X. Disponível em: <basu2002>.

BEHRER, A. P.; PARK, J. Will We Adapt? Temperature, Labor and Adaptation to Climate Change. Working Paper, p. 39p, 2017.

BURGESS, R. et al. Weather, Climate Change and Death in India. LSE Working Papers, p. 1-71, 2017. Disponível em: <http://www.lse.ac.uk/economics/Assets/Documents/personal-pages/robin-burgess/ weather-climate-change-and-death.pdf $>$.

BURKE, M.; HSIANG, S. M.; MIGUEL, E. Global non-linear effect of temperature on economic production. Nature Research Letter, v. 527, p. 16, 2015.

Business Insider. A third of the global population is on coronavirus lockdown. 2020. Disponível em: <https://www.businessinsider.com/ countries-on-lockdown-coronavirus-italy-2020-3>.

BUTLER, E. E.; HUYBERS, P. Adaptation of us maize to temperature variations. Nature Climate Change, Nature Publishing Group, v. 3, n. 1, p. 68-72, 2013.

BUTLER, E. E.; HUYBERS, P. Variations in the sensitivity of US maize yield to extreme temperatures by region and growth phase. Environmental Research Letters, IOP Publishing, v. 10, n. 3, p. 034009, mar 2015. Disponível em: <https://doi.org/10.1088\%2F1748-9326\%2F10\% 2F3\%2F034009>. 
CAI, X.; LU, Y.; WANG, J. The impact of temperature on manufacturing worker productivity: evidence from personnel data. Journal of Comparative Economics, Elsevier, v. 46, n. 4, p. 889-905, 2018.

CARLETON, T. A.; HSIANG, S. M. Social and economic impacts of climate. Science, v. 353, n. 6304, 2016. ISSN 10959203.

CASTRO, N. R.; SPOLADOR, H. F. S.; MARIN, F. R. Assessing the economy - climate relationships for Brazilian agriculture. Empirical Economics, Springer Berlin Heidelberg, p. 28, 2019. ISSN 1435-8921.

CHAN, K. H. et al. The effects of temperature and relative humidity on the viability of the SARS coronavirus. Advances in Virology, v. 2011, p. 7, 2011. ISSN 16878639.

CHEN, X.; YANG, L. Temperature and industrial output: Firm-level evidence from China. Journal of Environmental Economics and Management, Elsevier Ltd, v. 95, n. 2019, p. 257-274, 2019. ISSN 0095-0696.

COLMER, J. Weather, labor reallocation and industrial production: evidence from india. Working Paper, p. 1-128. 2020.

CONFALONIERI, U. et al. Coronavírus e clima. 2020. Disponível em: <http://climacom.mudancasclimaticas.net.br/ ulisses-confalonieri-elizabeth-rangel-maria-de-lourdes-oliveira-julia-menezes-e-rhavena-santos-coronavirus-e-clima/ $>$.

CURRIERO, F. C. et al. Temperature and mortality in 11 cities of the eastern United States. American Journal of Epidemiology, v. 155, n. 1 , p. 80-87, 2002. ISSN 00029262.

DASGUPTA, P. The place of nature in economic development. 1. ed. dasgupta2010: Elsevier BV, 2010. v. 5. 4977-5046 p. ISSN 15734471. ISBN 9780444529442. Disponível em: <http: //dx.doi.org/10.1016/B978-0-444-52944-2.00012-4>. 
DELL, M.; JONES, B. F.; OLKEN, B. A. Temperature shocks and economic growth: Evidence from the last half century. American Economic Journal: Macroeconomics, v. 4, n. 3, p. 66-95, 2012. ISSN 19457707.

DELL, M.; JONES, B. F.; OLKEN, B. A. What Do We Learn from the Weather? The New Climate-Economy Literature. Journal of Economic Literature, v. 52, n. 3, p. 740-798, 2014. ISSN 0022-0515.

DERYUGINA, T.; HSIANG, S. M. Does the Environment Still Matter? Daily Temperature and Income in the United States. 2014.

DESCHENES, B. O.; GREENSTONE, M. American Economic Association Climate Change, Mortality, and Adaptation : Evidence from Annual Fluctuations in Weather in the US. American Economic Journal : Applied Economics, v. 3, n. 4, 2011. Disponível em: $<$ deschenes2011 $>$.

DESCHENES, O. Temperature, human health, and adaptation: A review of the empirical literature. Energy Economics, Elsevier B.V., v. 46, p. 606-619, 2014. ISSN 01409883. Disponível em: $<$ http://dx.doi.org/10.1016/j.eneco.2013.10.013>.

DESCHENES, O.; GREENSTONE, M. The Economic Impacts of Climate Change : Evidence from Agricultural Output and Random Fluctuations in Weather. The American Economic Review, v. 97, n. 1 , p. 354-385, 2007.

DESCHÊNES, O.; MORETTI, E. Extreme weather events, mortality, and migration. Review of Economics and Statistics, v. 91, n. 4, p. 659-681, 2009. ISSN 00346535.

Dipartimento della Protezione Civile. Sito del Dipartimento della Protezione Civile - Emergenza Coronavirus: la risposta nazionale. 2020. Disponível em: <https://github.com/pcm-dpc/COVID-19>. 
FENG, S.; KRUEGER, A. B.; OPPENHEIMER, M. Linkages among climate change, crop yields and Mexico-US cross-border migration. Proceedings of the National Academy of Sciences, v. 107, n. 32, p. 14257-14262, 2010.

FERGUSON, N. M. et al. Impact of non-pharmaceutical interventions (NPIs) to reduce COVID-19 mortality and healthcare demand. Imperial.Ac.Uk, n. March, p. 3-20, 2020. Disponível em: $<$ https://doi.org/10.25561/77482>.

FERNANDES, N. Economic effects of coronavirus outbreak (COVID-19) on the world economy. SSRN, p. 0-29, 2020.

FICETOLA, G. F.; RUBOLINI, D. Climate affects global patterns of COVID-19 early outbreak dynamics. medRxiv, p. 2020.03.23.20040501, 2020.

FLAXMAN, S. et al. Estimating the number of infections and the impact of non-pharmaceutical interventions on COVID-19 in 11 European countries. Imperial College London, v. 13, n. March, p. 1-35, 2020. Disponível em: <https://doi.org/10.25561/77731>.

FRANKLIN, S.; LABONNE, J. Economic shocks and labor market flexibility. Journal of Human Resources, University of Wisconsin Press, v. 54, n. 1, p. 171-199, 2019.

GERUSO, M.; SPEARS, D. Heat, humidity, and infant mortality in the developing world. NBER Working Paper Series, p. 36, 2018.

GOUVEIA, N.; HAJAT, S.; ARMSTRONG, B. Socioeconomic differentials in the temperature-mortality relationship in São Paulo, Brazil. International Journal of Epidemiology, v. 32, n. 3, p. 390-397, 2003. ISSN 03005771.

GUIVARCH, C.; HALLEGATTE, S. 2c or not 2c? Global Environmental Change, Elsevier, v. 23, n. 1, p. 179-192, 2013. 
HANLON, W. W.; HANSEN, C. W.; KANTOR, J. W. Temperature, disease, and death in London: Analyzing weekly data for the century from 1866-1965. NBER Working Paper Series, p. 70, 2020. ISSN 1098-6596.

HSIANG, S. M. Temperatures and cyclones strongly associated with economic production in the Caribbean and Central America. Proceedings of the National Academy of Sciences, v. 107, n. 35, p. 15367-15372, 2010. ISSN 0027-8424.

HUYNEN, M. M. et al. The impact of heat waves and cold spells on mortality rates in the Dutch population. Environmental Health Perspectives, v. 109, n. 5, p. 463-470, 2001. ISSN 00916765.

JACOB, B.; LEFGREN, L.; MORETTI, E. The dynamics of criminal behavior evidence from weather shocks. Journal of Human resources, University of Wisconsin Press, v. 42, n. 3, p. 489-527, 2007.

JAYACHANDRAN, S. Selling labor low: Wage responses to productivity shocks in developing countries. Journal of political Economy, The University of Chicago Press, v. 114, n. 3, p. 538-575, 2006.

JESSOE, K.; MANNING, D. T.; TAYLOR, J. E. Climate change and labour allocation in rural mexico: Evidence from annual fluctuations in weather. The Economic Journal, Oxford University Press Oxford, UK, v. 128 , n. 608 , p. 230-261, 2018.

John Hopkins University. COVID-19 Dashboard by the Center for Systems Science and Engineering (CSSE). 2020. Disponível em: $<$ https://github.com/CSSEGISandData/COVID-19/blob/master/README.md $>$.

JÜNI, P. et al. Impact of climate and public health interventions on the COVID-19 pandemic: A prospective cohort study. Canadian Medical Association Journal, 2020. ISSN 0820-3946. Disponível em: $<$ http://www.cmaj.ca/lookup/doi/10.1503/cmaj.200920>. 
KAUR, S. Nominal wage rigidity in village labor markets. American Economic Review, v. 109, n. 10, p. 3585-3616, 2019.

KWOK, T. F. et al. The impacts of economic structure on china's carbon dioxide emissions: an analysis with reference to other east asian economies. Climate Policy, Taylor \& Francis, v. 18, n. 10, p. $1235-1245,2018$.

LIDDLE, B. Warming and income growth in the united states: A heterogeneous, common factor dynamic panel analysis. Climate Change Economics, World Scientific, v. 9, n. 04, p. 1850012, 2018.

LIN, K. et al. Environmental factors on the SARS epidemic: Air temperature, passage of time and multiplicative effect of hospital infection. Epidemiology and Infection, v. 134, n. 2, p. 223-230, 2006. ISSN 09502688.

LIPSITCH, M. Seasonality of SARS-CoV-2: Will COVID-19 go away on its own in warmer weather? Center for Communicable Disease Dynamics, Harvard, 2020. Disponível em: <https: //ccdd.hsph.harvard.edu/will-covid-19-go-away-on-its-own-in-warmer-weather/>.

LUO, W. et al. The role of absolute humidity on transmission rates of the COVID-19 outbreak. medRxiv, p. 7, 2020.

MASSETTI, E. et al. The Impact of Climate Change on the Brazilian Agriculture: A Ricardian Study at Microregion Level. CMCC, p. 31, 2013.

MENDELSOHN, R.; NORDHAUS, W. D.; SHAW, D. The Impact of Global Warming on Agriculture: A Ricardian Analysis. The American Economic Review, v. 84, n. 4, p. 753-771, 1994.

MENDELSOHN, R.; PEREDA, P.; WADE, D. Estimating non-linear effects with fixed effects panel models. Working Paper, 2019. 
MOTTA, R. S. da et al. Climate change and vulnerability to drought in the semiarid: the case of smallholder farmers in the Brazilian Northeast. In: Climate change in Brazil: economic, social and regulatory aspects. [S.l.: s.n.], 2011. p. 364. ISBN 9788578111281.

OLIVEIRA, J.; PEREDA, P. The impact of climate change on internal migration in brazil. Journal of Environmental Economics and Management, Elsevier, v. 103, p. 102340, 2020.

PEREDA, P. C.; ALVES, D. Climate and weather impacts on agriculture: The case of brazil. Economia Aplicada, v. 22, n. 3, p. $5-26,2018$.

PHILLIPS, T.; MAISONNAVE, F. Utter disaster: Manaus fills mass raves as COVID-19 hits the Amazon. The Guardian, p. 1-7, 2020. Disponível em: <https://www.theguardian.com/world/2020/apr/30/ brazil-manaus-coronavirus-mass-graves $>$.

PILCHER, J. J.; NADLER, E.; BUSCH, C. Effects of hot and cold temperature exposure on performance: a meta-analytic review. Ergonomics, v. 45, n. 10, p. 682-698, 2002.

RAMSEY, J. Task performance in heat: A review. Ergonomics, v. 38, p. $154-165,1995$.

RANSON, M. Crime, weather, and climate change. Journal of environmental economics and management, Elsevier, v. 67, n. 3, p. 274-302, 2014.

REIS, E. J. et al. Áreas Mínimas Comparáveis Para Os Períodos Intercensitários. 1o Simpósio Brasileiro de Cartografia Histórica, p. 16, 2011.

ROCHA, R.; SOARES, R. R. Water scarcity and birth outcomes in the Brazilian semiarid. Journal of Development Economics, Elsevier B.V., v. 112, p. 72-91, 2015. ISSN 03043878. Disponível em: $<$ http://dx.doi.org/10.1016/j.jdeveco.2014.10.003>. 
SAJADI, M. M. et al. Temperature, humidity, and latitude analysis to predict potential spread and seasonality for COVID-19. SSRN, n. 410, p. 1-13, 2020. Disponível em: <https://ssrn.com/abstract=3550308>.

SCHLENKER, W.; HANEMANN, W. M.; FISHER, A. C. Will U.S. Agriculture Really Benefit from Global Warming? Accounting for Irrigation in the Hedonic Approach. The American Economic Review, v. 95, n. 1, p. 395-406, 2005.

SCHLENKER, W.; HANEMANN, W. M.; FISHER, A. C. The impact of global warming on us agriculture: an econometric analysis of optimal growing conditions. Review of Economics and statistics, MIT Press, v. 88, n. 1, p. 113-125, 2006.

SCHLENKER, W.; LOBELL, D. B. Robust negative impacts of climate change on African agriculture. Environmental Research Letters, v. 5, p. 8, 2010.

SCHLENKER, W.; ROBERTS, M. J. Nonlinear temperature effects indicate severe damages to U.S. crop yields under climate change. Proceedings of the National Academy of Sciences, v. 106, n. 37, p. 15594-15598, 2009.

SEPPÄNEN, O.; FISK, W.; LEI, Q. Effect of Temperature on Task Performance in Office Environment. Ernest Orlando Lawrence Berkeley National Laboratory, p. 11, 2006.

SILVA, W. K. d. M. et al. Effects of climate change on sugarcane production in the state of Paraíba (Brazil): a panel data approach (1990-2015). Climatic Change, Climatic Change, n. 154, p. 195-209, 2019.

SOMANATHAN, E. et al. The Impact of Temperature on Productivity and Labor Supply: Evidence from Indian Manufacturing. Working Paper, p. 70, 2018. 
SON, J. Y. et al. The impact of temperature on mortality in a subtropical city: effects of cold, heat, and heat waves in São Paulo, Brazil. International Journal of Biometeorology, v. 60, n. 1, p. 113-121, 2016. ISSN 00207128.

SONG, X. et al. Impact of ambient temperature on morbidity and mortality: An overview of reviews. Science of the Total Environment, Elsevier B.V., v. 586, n. 222, p. 241-254, 2017. ISSN 18791026.

Disponível em: <http://dx.doi.org/10.1016/j.scitotenv.2017.01.212>.

SUN, L.; LI, H.; WARD, M. N. Climate Variability and Corn Yields in Semiarid Ceará, Brazil. Journal of Applied Meteorology and Climatology, v. 46, p. 226-240, 2007.

TAN, J. et al. An initial investigation of the association between the SARS outbreak and weather: With the view of the environmental temperature and its variation. Journal of Epidemiology and Community Health, v. 59, n. 3, p. 186-192, 2005. ISSN 0143005X.

The Lancet. COVID-19: learning from experience. The Lancet, Elsevier Ltd, v. 395, n. 10229, p. 1011, 2020. ISSN 1474547X.

Disponível em: <http://dx.doi.org/10.1016/S0140-6736(20)30686-3> .

The New York Times. Can't Get Tested? Maybe You're in the Wrong Country. 2020. Disponível em: <https://www.nytimes.com/2020/03/20/world/ europe/coronavirus-testing-world-countries-cities-states.html $>$.

THUNSTRÖM, L. et al. The benefits and costs of using social distancing to flatten the curve for COVID-19. Journal of Benefit-Cost Analysis, n. April, p. 1-27, 2020. Disponível em: <https://www.cambridge. $\mathrm{org} /$ core/article/benefits-and-costs-of-using-social-distancing-to-flatten-the-curve-for-covid19/ 204BD93C135EC727FAEFC62E3BE72C3B > .

TOSEPU, R. et al. Correlation between weather and Covid-19 pandemic in Jakarta, Indonesia. Science of the Total Environment, v. 725, 2020. ISSN 18791026. 
WANG, J. et al. High Temperature and High Humidity Reduce the Transmission of COVID-19. arXiv Populations and Evolution, n. 61572059, p. 1-19, 2020. Disponível em: $<$ http://arxiv.org/abs/2003.05003?utm $\{\backslash\}$ source=researcher $\{\backslash\}$ app $\{\&\}$ utm $\left\{\backslash \_\right\}$medium $=$ referral $\{\&\} \operatorname{utm}\left\{\backslash \_\right\}$campaign $=\operatorname{RESR}\left\{\backslash \_\right\} \mathrm{MR}>$.

WELCH, J. R. et al. Rice yields in tropical/subtropical Asia exhibit large but opposing sensitivities to minimum and maximum temperatures. Proceedings of the National Academy of Sciences, v. 107, n. 33, p. 1452-14567, 2010.

WILDE, J.; APOUEY, B. H.; JUNG, T. The effect of ambient temperature shocks during conception and early pregnancy on later life outcomes. European Economic Review, Elsevier, v. 97, p. 87-107, 2017.

World Health Organization. QESA on coronaviruses (COVID19). 2020. Disponível em: <https://www.who.int/emergencies/diseases/ novel-coronavirus-2019/question-and-answers-hub/q-a-detail/q-a-coronaviruses > .

WU, F. et al. A new coronavirus associated with human respiratory disease in China. Nature, v. 579, n. 7798, p. 265-269, 2020. ISSN 14764687 .

XAVIER, A. C.; KING, C. W.; SCANLON, B. R. Daily gridded meteorological variables in Brazil (1980-2013). International Journal of Climatology, v. 36, n. 6, p. 2644-2659, 2016. ISSN 10970088.

XAVIER, A. C.; KING, C. W.; SCANLON, B. R. An update of Xavier, King and Scanlon (2016) daily precipitation gridded data set for the Brazil. p. 562-569, 2017.

XIE, J.; ZHU, Y. Association between ambient temperature and COVID-19 infection in 122 cities from China. Science of the Total Environment, Elsevier B.V., v. 724, p. 138201, 2020. ISSN 18791026. Disponível em: < https://doi.org/10.1016/j.scitotenv.2020.138201>. 
$\mathrm{XU}$, Z. et al. Impact of ambient temperature on children's health: A systematic review. Environmental Research, Elsevier, v. 117, p. 120-131, 2012. ISSN 00139351. Disponível em: <http://dx.doi.org/10.1016/j.envres.2012.07.002> .

YAO, Y. et al. No Association of COVID-19 transmission with temperature or UV radiation in Chinese cities. The European respiratory journal, 2020. ISSN 13993003.

ZHANG, K. et al. What weather variables are important in predicting heat-related mortality? A new application of statistical learning methods. Environmental Research, Elsevier, v. 132, p. 350-359, 2014. ISSN 10960953. Disponível em: <http://dx.doi.org/10.1016/j.envres.2014.04.004>.

ZHANG, P. et al. Temperature effects on productivity and factor reallocation: Evidence from a half million chinese manufacturing plants. Journal of Environmental Economics and Management, Elsevier Inc., v. 88, p. 1-17, 2018. ISSN 0095-0696.

ZHOU, P. et al. A pneumonia outbreak associated with a new coronavirus of probable bat origin. Nature, Springer US, v. 579, n. 7798, p. 270-273, 2020. ISSN 14764687. Disponível em: $<$ http://dx.doi.org/10.1038/s41586-020-2012-7>.

ZIVIN, J.; NEIDELL, M. Temperature and the allocation of time: Implications for climate change. Journal of Labor Economics, University of Chicago Press Chicago, IL, v. 32, n. 1, p. 1-26, 2014. 